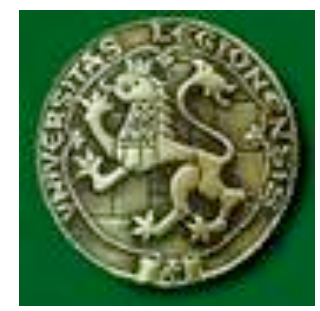

UNIVERSIDAD DE LEÓN

FACULTAD DE FILOSOFÍA Y LETRAS

DEPARTAMENTO DE FILOLOGÍAS MODERNAS

THE FILMS OF PEDRO ALMODÓVAR:

TRANSLATION AND RECEPTION

IN THE UNITED STATES

MARÍA ROX BARASOAIN

2008 


\title{
THE FILMS OF PEDRO ALMODÓVAR: TRANSLATION AND RECEPTION IN THE UNITED STATES
}

Tesis doctoral presentada por $\mathrm{D}^{\mathrm{a}}$. María Rox Barasoain para la obtención del título de Dra. en Filología Inglesa por la Universidad de León, co-dirigida por el Catedrático Dr. D. Julio César Santoyo Mediavilla y la Dra. Da. Micaela Muñoz Calvo

UNIVERSIDAD DE LEÓN

FACULTAD DE FILOSOFÍA Y LETRAS DEPARTAMENTO DE FILOLOGÍAS MODERNAS

\author{
MARÍA ROX BARASOAIN
}

2008 
To my parents and brother

(A mis padres y hermano) 


\section{Acknowledgements}

This dissertation became an adventure that took me much farther than I could have imagined. Along the way, there were many individuals whose guidance and encouragement made all this a reality.

First, I would like to thank Professor Julio César Santoyo Mediavilla for supervising this thesis, for devoting so much valuable time to provide me with feedback, and for his support and encouragement through difficult times. I would also like to thank Dr. Micaela Muñoz Calvo for her help and extensive support during all these years. I have learned a great deal from her experience and vast knowledge in the field of translation studies. I wish to thank her for being such a great person and for making the arduous task of writing a dissertation easier than it would have otherwise been. It was in her doctoral course that I was introduced into the fascinating world of translation studies, and where the ideas behind this thesis germinated.

This dissertation is dedicated to my parents, Octavio and Marisol, whose unwavering support has always been of primary importance to me, and whose dreams have (I hope) finally come true. It is also dedicated to my brother Oscar who, in his own, particular way, has supported me as well. He has finally cleared his room of all my papers and no longer needs to suffer through my printing of thousands of sheets every single day. I thought I would finish this thesis before his wedding, but he was faster. My thanks also go to Patricia, his wife, who always encouraged me along the way.

While many of my friends and family members lent me broad support along the way, some have made specific contributions to this 
dissertation. I wish to thank my dear friend Javier Muñoz-Basols who helped me a great deal with his knowledge and advice. His experience in the field of linguistics was essential, and his encouragement was of vital importance during difficult moments. He was an excellent host, together with Paweł Adrjan, during my stays in New York. They convinced me that I could do it. Thank you for sharing your knowledge with me, for devoting so much time to me, and for being such great friends. You know that this thesis is also part of you. From this day on, new adventures are awaiting us.

My gratitude also goes to my friend Francisco Fernández, a former professor at Bucknell University, whose thorough knowledge of cinema opened my eyes to this art. He helped me discover many new films, which have proven essential for this thesis. I will always remember our weekly meetings in which we talked about the sorrows of the neverending process of writing. Once again, congratulations on your Ph.D.!

I wish to thank Timothy Bozman, whose corrections have been invaluable. Thanks a lot for accepting this arduous task and for proofreading my work with such meticulousness. It was an honour that you agreed to help me, and it has been a pleasure to work with you again. I would also like to thank Marianne David at the Trinity School in New York, and Sabrina Kirby, a Writing Center tutor at Bucknell University, for their help and suggestions.

I am especially grateful to the Gobierno de Navarra for the grant I received, which made this dissertation possible. I also owe my gratitude to Professor Alice Poust and Professor Manuel Delgado, at Bucknell University, for giving me the opportunity to work with them. Those two years were the beginning of my research on the reception of Spanish cinema by an American audience and were the source of inspiration for my ideas. 
And last, but not least, I owe special thanks to Eliseo for his support and love. When you came into my life, you gave me the feel I had been longing for. Thanks for encouraging me through the last stages of my work, and thanks for being so proud of me, as I am of you. I am so glad you witnessed the end of this dissertation. 


\section{Table of Contents}

I. INTRODUCTION

II. TRANSLATION STUDIES AND AUDIOVISUAL TRANSLATION

1. A Brief Introduction to the Discipline of Translation Studies $\quad \mathbf{1 6}$

1.1. Central Issues in Translation 23

1.1.1. Equivalence 23

1.1.2. Norms $\quad 26$

1.2. Translatability and Untranslatability 31

1.3. Domestication and Foreignisation 35

1.4. Language, Culture and Translation 38

1.5. The Translation of Humor 41

1.5.1. What is Humor? 41

1.5.2. Humor Appreciation $\quad 44$

1.5.3. The Translation of Humor 46

2. Audiovisual Translation 52

2.1. The Term 'Audiovisual Translation' 52

2.2. Two Main Methods of Audiovisual Translation in

Films: Dubbing and Subtitling 58

2.3. Definition of Subtitling $\quad 64$

2.4. The Origin of Subtitles $\quad 66$

2.5. Types of Subtitling $\quad 72$ 
2.6. Interlingual or Conventional Subtitling 73

2.7. General Features 74

2.7.1. Length and Time $\quad 74$

2.7.2. Formatting, Expressiveness and Style of

Subtitles 78

2.8. Subtitling: An Intelligent Solution $\quad 85$

2.9. Constraints $\quad 88$

2.9.1. Technical Constraints $\quad 89$

2.9.2. Textual Constraints 90

2.9.3. Linguistic Constraints 92

2.10. The Film, the Film Translator, and the Audience 96

2.11. Subtitled Films in the US and Europe 101

2.12. Familiarity with the SL: An Added Value 104

III. THE CINEMA OF PEDRO ALMODÓVAR 106

1. Pedro Almodóvar: A Spanish Film Director 106

1.1. Characteristics of His Films 108

1.2. Pedro Almodóvar: A Postmodern Film-Maker 119

2. The Reception of Almodóvar's Films in the United States $\mathbf{1 2 2}$

2.1. Reception Theory and Reception Studies 122

2.1.1. Modes of Reception 126

2.1.2. Dominance of Film and Video Industry by the United States 129

2.1.3. Censorship in the United States 130

2.1.4. Censorship in Spain 138

2.2. The Reception of Pedro Almodóvar's Films in the 
2.2. The Reception of Pedro Almodóvar's Films in the United States 140

2.2.1. Almodóvar's Films: Nominations and Awards $\quad \mathbf{1 6 0}$

3. The Translation of Almodóvar's Films 171

3.1. Methodological Aspects 171

3.1.1. Corpus 171

3.1.2. Delimitation of the Object of Analysis 172

3.1.3. Model of Analysis 173

A) Preliminary Aspects 173

B) Microstructure $\quad 176$

3.2. Application of the Model of Analysis 177

3.2.1. Insulting and Scatological Expressions $\quad 178$

3.2.2. Expressions Concerning Sexual and Bodily

Functions 201

3.2.3. Expressions concerning Rural Life 218

3.2.4. Swearing 235

3.2.5. Slang and Colloquial Expressions 241

3.2.6. Accent 278

3.2.7. Culture Bound References 293

3.2.7.1. Food References $\quad 306$

3.2.8. Vocabulary Related to Drugs 313

3.2.9. Wordplay and Sayings 315

3.2.10. Errors in the Subtitles of the Films $\quad 320$

3.3. Summary of the Methods and Conclusions 324

IV. CONCLUSIONS 334 
1.1.Translation Studies $\quad 347$

1.2.Audiovisual Translation 351

1.3. Translation of Humor 358

1.4.Reception Studies $\quad \mathbf{3 6 0}$

1.5.Pedro Almodóvar $\quad 362$

1.6.Films by Pedro Almodóvar 366

$\begin{array}{ll}\text { 1.7.Dictionaries and Manuals } & \mathbf{3 6 7}\end{array}$

1.8. Websites $\quad 368$ 


\section{I \\ Introduction}

This dissertation is the outcome of my admiration for Pedro Almodóvar and his work, as well as of my own professional and academic interest in the English language. After seeing the screening of Todo sobre mi madre in a movie theatre in 1999, I began to think about the problems audiovisual translators come across in the process of translating Almodóvar's films, given his very particular use of language and humor. I thought that translating the speech of a character like Agrado might be very complicated for the translator, and I wondered what effect the subtitled version would have on a US audience. In fact, seeing Todo sobre mi madre encouraged me to discover the rest of Almodóvar's work, and to follow his development through the years. In this long research I have become acquainted with the main characteristics of Almodóvar's work, his characters, and the ideas and beliefs that he expresses through them.

In the last five years, I have compiled many articles and books on this film director and his way of making films, and also on audiovisual translation. My research started during my two years at Bucknell University (Lewisburg, PA), working in the Spanish Department. The facilities of Bucknell's Library made this study possible, as I probably would not have found such a wealth of materials here in Spain. I found almost all his films with English subtitles, and they comprise the corpus of this dissertation

I would like to add that I was very surprised to discover so many studies on Almodóvar, and to read positive critiques of his films, most of 
them from the Anglo-American world, in contrast to Spain where Almodóvar's films have received mostly negative reviews. It seems that nobody is a prophet in their own land. It is only now that the Spanish director is finally achieving the fame and acceptance he has always longed for in his own country. 2006 was the year of Volver, his latest film. Almodóvar has thus come back to his origins to create a film, once again about women. This dissertation is about audiovisual translation, and the analysis of the subtitles in Almodóvar's films its main focus.

Iniciado el siglo XXI, vivimos inmersos en un tipo de sociedad dominada, influida, e incluso dirigida por los medios audiovisuales. Los medios audiovisuales se han convertido en el vehículo principal de transmisión de información, de cultura y de ideología. (Chaume 2004: 7)

Given its own massive film production, the US does not import a large number of foreign films, but those imported are all subtitled. At first, dubbing was the method used to deal with foreign films. However, audiences started to react against these dubbed versions, and this made the distribution companies opt for subtitling. Nowadays Almodóvar's films are subtitled in the US. Nevertheless, after the success of the Academy Award nomination of Mujeres al borde de un ataque de nervios in US box offices in 1989, Almodóvar's next two films ¡Átame! and Tacones lejanos - were dubbed because Almodóvar's distribution company thought dubbed versions would attract larger numbers of spectators. But it was a wrong decision. As Hart (1994: 265) states, many critics that had long admired his work, launched devastating critiques against him, and even accused him of being a misogynist.

Large countries that invest heavily in audiovisual translation usually favor dubbing, yet the US film market seems to ignore this 
economic factor, and focuses on its audiences' preferences. To be able to hear the original soundtrack while reading the translation is probably a good reason for such a preference. Thus, the corpus of this thesis deals with subtitled versions - and not dubbed ones - commercialized in the US.

In section II, I briefly introduce the discipline of Translation Studies in order to establish the role of Audiovisual Translation in this field. The birth of translation studies can be traced back to the XXth century when an increase in the need for translations prompted the creation of translation schools and colleges. There are some key issues in translation studies which are central to the translation of Almodóvar's films, such as equivalence, norms, the translation of culture, and humor.

In the analysis of the translations, I follow Nida's concept of dynamic equivalence based on the principle that an equivalent effect is what determines the success of a given translation. In order to reach the equivalent effect, the subtitlers of these films will have to resort to equivalence in order to produce a target text (henceforth TT) that transmits the message and the flavor of the source text (henceforth ST).

Linked to the concept of equivalence is the notion of norms, or the directives that prevail over the members of a specific community. For socio-cultural factors will undoubtedly affect the translation of these films, given the differences between source and target cultures:

At a macro-structural level, these norms allow us to determine which are the distinctive characteristics that regulate the delivery of the dubbed or subtitled discourse, bearing in mind the many different constraints imposed by the medium. At a micro-structural level, they help us to observe the translator's behaviour in the linguistic mediation. (Díaz Cintas 2004: 26) 
These norms will determine what is accepted as a translation in the US culture, as they govern the translator's judgment concerning either the adequacy of the translation to the ST, or the acceptability of the translation in the target culture. Indeed, these two concepts adequacy and acceptability - are crucial in determining whether the translators of Almodóvar's films are faithful to the ST, by trying to preserve the peculiarities of the language, or on the other hand, by submitting to the norms that govern the target culture, and thereby trying to achieve an acceptable translation. If translators opt repeatedly for the same solution in a particular translation, one can conclude that the directives imposed by the target norms have been followed by these professionals.

In the debate on whether everything is translatable or not, cultural references are thought to offer the greatest difficulty in the translation process, and Almodóvar's films are full of cultural references. Both target cultures, the Spanish and the US, differ significantly in terms of life style, traditions, etc., which will obviously lead to problems in the translation of cultural items. In such instances, the translator will have to opt for either the adequacy or the acceptability of the translation, which presupposes a good knowledge of both source and target languages. Indeed, any translator of Almodóvar's films will need to be thoroughly acquainted with both cultures in order to come up with a successful translation. For at some points in the translation process, the translator has to opt for either the "domestication" of the text by maintaining a clear and fluid style acceptable to the target receptor, or the foreignization of the TT that preserves the special flavor of the ST.

The relation between language and culture is crucial in translation, since texts cannot be detached from the socio-cultural medium in which they are produced. As Casagrande (1954: 335) has stated, "one does not translate languages, one translates cultures". So in 
order to understand a language, one has to know the way in which that target culture behaves. Culture determines the lifestyle of a community. From a cognitive perspective, it guides the behavioral patterns of its members, and covers the range of knowledge shared by them. Culture pervades the film from beginning to end, so that an unsuccessful translation of any cultural reference related to Spain and its language will result in a loss of information of the ST, with the result that the target audience will be deprived of the significant flavor and spirit of the film.

A notable characteristic of Almodóvar's films is the use he makes of "black humor" - humor being a cognitive process deeply linked to culture. The translation of the humor present in these films represents one of the biggest challenges for the translator. Just as the members of a given community are not expected to react in the same way to humor (due to age, sex, and other factors), so the audiences from different cultures are also presumed to react in very different ways. Whether or not the translators have been able to preserve the original humor will be easily verified by noting whether the target audience laughs at the same moments as the source audience does, keeping in mind that most of the humor of Almodóvar's characters is to be found not so much in what they say, as in how they say it.

Whereas all works of translation - novels, poetry, manuals, etc. entail difficulties for the translator, even more serious obstacles are to be faced when two different modes - the written and the oral - combine. Out of the dominant types of audiovisual translation - interlingual subtitling, dubbing, consecutive interpreting, simultaneous interpreting, voice-over, free commentary, simultaneous (or sight) translation, and multilingual productions (Gambier 2003: 172) -, the two most frequently used for cinematographic translation are dubbing and subtitling. Both present significant examples of the difficulties found in the translation process. As mentioned before, the method I focus on in this study is 
subtitling, as the films analyzed are in Spanish with American English subtitles. Accordingly, in section II, I introduce a summary of Audiovisual Translation with a focus on the subtitling method and all the concepts related to this technique.

In section III the main characteristics of the cinema of Almodóvar are described. The Academy award nomination of Mujeres al borde de un ataque de nervios in 1989 was the starting point for his success in the US. Being branded as a bizarre director in his own country, with not many people liking his films which were regarded as tasteless, US audiences started to praise Almodóvar's work, and many scholars and film critics focused on him. As a result, he has won a place in the syllabus of many college film courses given in the US.

One of the most popular postmodernist film directors today, Almodóvar's way of making films has been compared with that of Sirk, Fassbinder or Buñuel, even though he does not feel close to any of these directors. His admiration for classic films and the melodramatic genre is reflected in every one of his films, as they always include an allusion or image taken from classic Hollywood melodramas. Emphasizing the female point of view, most of his works have female protagonists - except for La mala educación, whose main protagonists are male. Music also plays an important role: songs are introduced at peak moments, and the lyrics are always related to the plot. The prominent position of women in Almodóvar's films has characterized him as a "woman's director", and feelings and passion are central elements. Criticized for being an anti-historicist, he opts to include historical references in a fictitious and theatrical way. He is also a representative of camp aesthetics, as seen in the presence of women magazines, sentimental songs, and in the figure of the transvestite. To be sure, Almodóvar includes 
stereotypes that are not usually dealt with in cinema, from the lower echelons, transvestites, drug-addicts, and prostitutes.

Indeed, Almodóvar's postmodernism constitutes the originality of his work, which breaks with the film tradition of Franco's Spain, and makes him free to do what he likes: what he does is present the spectator with a new type of cinema, one in which the use of color, the emphasis on acting, and the lack of references to the past are some of the postmodernist features.

I then go on to briefly present an introduction to the theory of $\underline{\text { Reception Studies and the different modes of reception. Just as the }}$ role of the reader is essential to literature, so is the role of the spectator essential to cinema. Receptors (readers and spectators) are an area of Reception Studies, and their reactions are fundamental to the commercialization of the product in question. The goal of Reception Studies is to explain how individuals have understood texts, and to understand the relationship between viewers and films or readers and texts. Research on how audiences receive films serves not only to predict their failure or success, but also to gather information about the political situation at the time of their release, the consumer needs of society, etc. In the reception process, factors such as cognitive and affective audience, behavior and history must be taken into account. In this study, the spectator of Almodóvar's films has a prominent and central position, and the fact that there are two audiences that significantly differ from each other in terms of culture, language, or lifestyle plays an important role in reception analysis.

In the reception process, censorship plays an important role. The increasing success of Almodóvar's work in the US has been essential for the worldwide recognition of his filmography. However, the US film market has been affected by the intervention of a moral 
censorship from which the director has not been able to free himself. In fact, moral censorship has always ruled US society. A book (1994) and an article (2001) by Black explain the origin of censorship in the US by the Legion of Decency, and how it lasted until our time through the MPAA.

$\underline{\text { Renowned film critics and scholars such as Cardullo, Cadalso, }}$ Holland, Pitt or Russo, among others, have examined his work, and made enriching as well as cynical critiques. I present some of these comments and critiques concerning Almodóvar's way of directing, and concerning the films themselves, both in Spain and the US. The list of the nominations and awards his films have won from the beginning of his career is good proof of his success and support from film circles all over the world.

Almodóvar has directed sixteen films so far, of which I have decided to include ten in the corpus of this dissertation:

III.Laberinto de pasiones [Labyrinth of Passions] (1982)

IV. ¿Qué he hecho yo para merecer esto? [What Have I Done to Deserve This?] (1984)

V. Matador [Matador] (1985)

VI. La ley del deseo [Law of Desire] (1987)

VII. Mujeres al borde de un ataque de nervios [Women on the Verge of a Nervous Breakdown] (1988)

VIII. ;Átame! [Tie me up! Tie me down!] (1990)

IX. Tacones lejanos [High Heels] (1991)

X. Kika $[\mathrm{Kika}](1993)$

XI. Carne trémula [Live Flesh] (1997)

XII. Todo sobre mi madre [All About My Mother] (1999)

My work was done with the help of the films commercialized in the US, with dialogues transcribed directly from the screen. When I began this research most of the scripts of the films I was going to 
use in the corpus were not available (except for the script of Todo sobre mi madre, which had been published in 1999): "la explicación es que tradicionalmente los estudios cinematográficos consideraban que los guiones eran material de carácter confidencial y de alto valor estratégico" (Bravo 2005: 126). With the arrival of the DVD many countries managed to create two different tracks of interlingual subtitles in films: one for the hearing population and a second one that addressed the needs of the deaf (Díaz Cintas \& Remael 2007: 18). As this research was being carried out, DVDs started to appear in the film market; yet, I decided not to focus on the subtitles that appear in them, as it would have broadened my study, due to the fact that the format of the subtitles entirely depends on the medium used for the distribution of the audiovisual material:

[...] Cinema subtitling tends to use shorter lines and centre them, despite the fact that the lines can actually be longer than on television. It also tends not to condense the original dialogue as much as television and to show great respect for shot changes and cuts in the spotting. The result is that the same film subtitled for the cinema usually has more subtitles than when subtitled for television. DVD is similar to cinema, but shows less respect for cut changes and prefers to use longer lines that can be easily read on a relatively small screen compared to the cinema one. The result is fewer subtitles than for the cinema, though not more condensation of information. (Díaz Cintas \& Remael 2007: 24)

Even though every film has its corresponding English title, I always refer to the Spanish title, as I intend to preserve the original flavor of these works. The dialogues that were not translated are represented by the following symbol: ":::::::". In the analysis I decided to use charts to make salient the text and study of the 
translations. These charts display the Spanish title of the film and the year of its release, the ST dialogue, and its English subtitles. Some of these charts display bold letters in order to present the source word or expression and its translation more clearly.

The Spain reflected in his films is a country of stereotypes with a whole range of well-defined and easily identifiable features. Deep cultural references pervade all his films, and these cultural differences among source and target cultures account for the impossibility of translating a text without losing the originality of the ST. My study shows clearly the difficult process of translating for the screen, when the source and target cultures are so different.

I present my own model of analysis, which I devised by following different proposals by Ballester Casado (2001a), Gutiérrez (2000) and Díaz Cintas (1998). This analysis has two levels: preliminary aspects and microstructure. The preliminary aspects deal with questions such as the position of source and target cultures in an international context, the relation between both cultures, the reasons why subtitling has been preferred to dubbing, and film genre. All the issues dealt with in this section are used to explain some part of the process of translation. Thus it is easy to recognize the general intention of the work, as well as the bias of the translation towards the target system (acceptability) or, on the contrary, towards the source system (adequacy).

On the other hand, the microstructure analysis examines all those fragments - or linguistic units - of the films that present significant characteristics worth commenting on, and relevant to understanding the translation process. While analyzing the films, I came across a great deal of examples that could have been relevant to $\mathrm{my}$ research. Due to the fact that most of the subtitles reflected pertinent ideas, I needed to focus on several aspects in order to make 
a selection for the subsequent analysis. Since it would have been impossible to include all the subtitles in my research, the examples that have not been commented here will constitute part of future publications. Notwithstanding, I am enclosing a CD with all the examples taken from the films. On the level of microstructure, I analyze elements such as the translation of:

- insulting and scatological expressions,

- expressions concerning sexual and bodily functions,

- expressions concerning rural life,

- swearing,

- slang and colloquial expressions,

- accent,

- culture-bound references,

- vocabulary related to drugs,

- wordplay and sayings, and

- errors found in the subtitles.

In this study, I analyze those instances in which the equivalent effect has been achieved, and where the TT has faithfully reproduced the message and atmosphere of the ST, as well as those in which the translators have not achieved equivalence, thus giving rise to a translation that differs slightly or largely from the ST. In section 3.3, I present a summary of the methods and conclusions of this analysis.

Then, section $I V$ presents the final conclusions drawn from this research.

Since I began this research I have tried to read almost everything published about Almodóvar's works, Translation Studies, Audiovisual Translation, and Reception Studies, and I have collected as many books and articles as possible. Yet the bibliography included in section $V$ only includes the works mentioned in the study. 


\title{
Translation Studies
}

\author{
and \\ Audiovisual Translation
}

C) A Brief Introduction to the Discipline of Translation

\section{Studies}

In the $20^{\text {th }}$ century an increase in communications among industrialized countries brought about an increasing need for translations, and for professional translators, hence the creation of translation schools and colleges.

During the first half of the $20^{\text {th }}$ century, translation was seen as an important medium for reaching the literary text, and little by little it became an autonomous discipline. Two main approaches emerged: those that saw translation as a transaction among languages, and those that focused on its textual nature. One of the most important changes in this century was the move from 
translation theory to translation science (Übersetzungswissenschaft) with the introduction of Translation Studies as a university level discipline:

La esencia de la disciplina Estudios de Traducción son los hechos (observables 0 reconstruibles) de realidad, y no las entidades meramente especulativas resultado de hipótesis y modelos preconcebidos, y esto es así, tanto si uno prefiere centrar sus esfuerzos en los textos traducidos y/o sus constituventes, o en las relaciones intertextuales, en los modelos y normas de comportamiento traductor $o$ en las estrategias a las que se recurre para solucionar problemas concretos. Esta ciencia es empírica por naturaleza y hay que tratarla como tal. Sin embargo [...] los Estudios de Traducción están aún haciéndose. (Toury 2004: 35-36)

James S. Holmes, in his article "The Name and Nature of Translation Studies," during the Third International Congress of Applied Linguistics (Copenhagen, 1972), was the first one who dealt with the terminology applied to these studies. Since then:

[...] El nombre Estudios de Traducción ha ido ganando cada vez más terreno en los círculos académicos de habla inglesa. Ha desplazado a una posición periférica denominaciones alternativas como "Science of Translating" [...] "Science of Translation" $[\ldots], 0$ "Traductología". (Toury 2004: 43)

According to Holmes, translation studies had two main objectives:

(1) To describe the phenomena of translating and translation(s) as they manifest themselves in the world of our experience, and (2) to 
establish general principles by means of which these phenomena can be explained and predicted" (Holmes 1994: 71)

Thanks to Holmes' principles, something that benefited greatly from conferences held in the late $70 \mathrm{~s}$, "the discipline began to gain momentum and weight" (Díaz Cintas 2004: 22). Nevertheless, as Hermans (1999: 8) affirms, the term Translation Studies, far from only referring to the specifically descriptive line of approach, has evolved to refer to the whole field of study.

Holmes divided the new discipline of translation studies into a 'pure' and an 'applied' branch. The pure branch included theory and descriptive studies, and the applied branch included teaching, aids and criticism of translation. As for descriptive studies, it was subdivided into three types: product, function and process-oriented. By means of this division, Holmes implied that the discipline was an empirical one, constituting "a field of pure research" (Holmes 1988: 71). He claimed the relation among the three branches (theoretical, descriptive, and applied) as being "a dialectical one, with each of the three branches supplying materials for the other two, and making use of the findings which they in turn provide it" (Holmes 1988: 78). He also mentioned two further dimensions that have to do with the study of Translation Studies: the historical and the methodological. Translation scholars started to proliferate, as well as publications and conferences dealing with the new discipline:

Esta corriente teórica, cuyos orígenes datan de mediados de los años setenta, ha sido una de las más prolíficas y enriquecedoras en el terreno de la traducción. Con una subdivisión disciplinar tripartita en las ramas teórica, descriptiva y aplicada, su objetivo consiste en establecer un nuevo paradigma que permita el estudio 
de los fenómenos traductores desde nuevos parámetros, con especial hincapié en la dimensión empírica, e instituyendo como objeto de estudio el propio texto traducido y no su índice de fidelidad respecto al texto de origen (TO). (Díaz Cintas 2001: 93-94)

\section{According to Hermans (1985: 10-11), all translation studies scholars:}

[...] Have in common $[\ldots]$ an approach to literary translation which is descriptive, target-oriented, functional and systemic; and an interest in the norms and constraints that govern the production and reception of translations, in the relation between translation and other types of texts processing, and in the place and role of $\underline{\text { translations both within a given literature and in the interaction }}$ between literatures.

During the second half of the $20^{\text {th }}$ century, the approach to translation was mainly linguistic due to the growth of machine translations. Its main focus was on the languages involved, and on trying to solve syntactical and morphological problems. It was at that point that scholars realized that whenever there was a translation problem, it could not be solved without resorting to context, or extra-linguistic information.

Following Díaz Cintas (2004), I will try to analyze the validity and functionality of a series of concepts articulated within the theoretical framework known as Descriptive Translation Studies (DTS), and apply them to the field of audiovisual translation, as:

[...] No se puede considerar que una ciencia empírica [Estudios de Traducción] esté desarrollada y sea (relativamente) autónoma a menos que cuente con una sólida rama descriptiva. El objetivo de tal disciplina 
sería describir, explicar y predecir fenómenos relacionados con su objeto de estudio. (Toury 2004: 35)

In the decade of the $70 \mathrm{~s}$, Even-Zohar coined the term polysystem in a series of papers published in English. By means of this term he referred to "a group of semiotic systems that co-exist dynamically within a particular sphere, [...] characterized by continuous changes and internal oppositions, whose main aim is to occupy the centre position in the system, and it is regulated by sociohistoric norms" (Díaz Cintas 2004: 22):

I first suggested this concept in 1970 in an attempt to overcome difficulties resulting from the fallacies of the traditional aesthetic approach, which prevented any preoccupation with works judged to be of no artistic value. [...] It would be more convenient $[\ldots]$ to take all sorts of literary and semi-literary texts as an aggregate of systems. (Even-Zohar 1978b: 119)

Rabadán (1991: 294) defines the term in Spanish as "un conjunto de co-sistemas semióticos interrelacionados de forma dinámica y regulados por normas históricas, en el que se inscriben todas las actividades behavioristas y sociales del ser humano, incluida la propia traducción". This theory stresses the importance of a systemic approach, and polysystemists "shifted the attention away from individual literary translations to the study of a large body of translated literature in order to establish its systemic features" (Baker 1992: 238). The literary polysystem includes a range of literatures, from the canonical to works and genres considered minor (children's literature, thrillers, etc.), and translated works (Díaz Cintas 2004: 23). This new approach to translation regards the 
translated work as a product integrated in the target polysystem, and accounts for the change that has taken place in the discipline: from studying translation as a process - translating -, to focusing on the analysis of translation as a product - translation. If we try to apply this new theory to audiovisual translation, we could say that “dentro del polisistema fílmico, la traducción de películas es simplemente un componente más que están en lucha constante con otros estratos o co-sistemas $[. .$.$] por conseguir la supremacía dentro$ del polisistema" (Díaz Cintas 2001: 95), so:

The film polysystem is made up of the national products and the translated ones - dubbed or subtitled - and deals with the relationships that are established among all of them. $[\ldots]$ The advantages of this approach are manifold. [...] It blurs the boundaries between high and low culture, allowing the reclamation of social activities that have been traditionally marginalized in the academic exchanges, e.g. $[$.... $]$ audiovisual translation as opposed to literary or poetry translation.(Díaz Cintas 2004: 23)

Back in the 70s, translation studies were source oriented; however, a new approach to translation was gradually being developed in Germany by Vermeer (1978), the skopos theory: "con él quisieron subravar la importancia de la función del texto traducido en la cultura meta, que se convierte en el elemento extratextual más importante, es decir, el que determina prácticamente todas las estrategias del traductor" (Zaro Vera 2001: 51).

Vermeer highlights the basic principles that have governed translation and interpretation at certain periods of history. Based in part on his own SKOPOS THEORY, Vermeer's history seeks to 
determine the extent to which translators have taken account of cultural differences as well as the expectations and behavioural conventions of the target audience. (Woodsworth 2001: 104)

This new approach to translation reflected the shift from linguistic and formal translation theories to a more functionally and socioculturally oriented concept of translation (Schäffner 2001: 235). Now, the main focus was on the target reader, the target context, and on the translator as its main agent. Besides the text type, the aim or skopos of the translation would determine translation methods and strategies. This functionalist view of translation was preceded by the communicative approach of the Leipzig School, whose scholars defended the idea of translation seen as a special communicative act, and regarded linguistics as a significant discipline in the study of translation. Thus functionalism took over linguistics in translation studies and a new period was opened. Applying skopos theory to dubbing and subtitling "puede contribuir a explicar, sobre todo, la elección de una u otra modalidad de traducción" (Zaro Vera 2001: 51).

Times have changed, and the focus of written translation has shifted towards new developments. The arrival of cinema and TV has led to a shift in the discipline, as scholars have had to deal with a new product to be translated. Strikingly enough, it was not until the end of the $20^{\text {th }}$ century that they started to talk about Screen Translation, also called Audiovisual Translation. In 1995 the 100-year of the invention of cinema was celebrated by the Council of Europe with a forum on audiovisual communication and language transfer:

From that year on, we have had one or two colloquia and a consistent number of seminars and sessions within conferences 
each year. The number of publications has also risen significantly. Another reason could be the parallel booming of the so-called new technology, offering on-line and off-line products and services. We are now surrounded by screens. A third reason is language policy and language awareness, especially in Europe. Minority groups now realize that the media could be a useful tool to promote and reinforce their language and cultural identity. (Gambier 2003: 171)

The following issues to be analyzed are important to the present study, as they bear on the translation of Almodóvar's films. Equivalence and norms are two issues that are central to this analysis, the main goal of every translation being to reach equivalence so as to produce a valid target product. In most cases translators need to resort to the TL norms in order to generate a proper translation. Moreover, these translators sometimes come across problems with some words or expressions that give rise to questions of translatability and untranslatability. Here the translator's knowledge of both source and target languages (SL and TL from now on) is not sufficient, since what is needed is a thorough knowledge of both cultures in order to overcome these problems. And when faced with a cultural dilemma, the translator will often have to resort to two methods: either to the domestication or to the foreignization of the translation. The recipient of these translations, the US audience, definitely differs from the Spanish audience in terms of language, culture and humor, all of which need to be taken into account in the translation process. Finally, in the section that follows I give an introduction to the discipline of Audiovisual Translation, with a focus on the subtitling method, as it is the one chosen in the translation of Almodóvar's films in the US. 


\section{D) Central Issues in Translation}

\subsubsection{Equivalence}

The concept of equivalence is central to every theoretical method. It is also important in any inter-linguistic comparison, even though some theorists have attacked it.

In Toward a Science of Translation (1964), Nida distinguished between two types of equivalence: formal and dynamic. The latter is based on the principle of equivalent effect, leaving aside previous terms such as 'literal', 'free' and 'faithful' translation. Formal equivalence focuses on the message itself, both in its form and content. But due to the cultural and sociological differences among languages, formal equivalence is only possible in a rare number of occasions. For Nida the emphasis on formal equivalence produced translations that were neither faithful nor beautiful, whereas dynamically equivalent products could combine both qualities:

This emphasis on the dynamics of translation (as opposed to static features of text) became more popular because it allowed us to bring in the human element. (Baker 2004: 66)

In his translation of the Bible, Nida mentions the celebrated phrase "Lamb of God", whose literal translation (or formal equivalent) might create problems in a target culture, such as that of the Inuit for whom the word lamb is unfamiliar and thus has no meaning. Indeed, in the target culture a more dynamic equivalent would be "Seal of God", as the seal carries the same sense of innocence the lamb evokes in the 
source culture. Since the aim of any translation is to produce an effect on the TT reader that is identical to the one experienced by the reader in the $\mathrm{SL}$, three factors are required in order to achieve the "closest natural equivalent':

Equivalent which points toward the source language message; natural which points toward the receptor language, and closest which binds the two orientations together on the basis of the highest degree of approximation. (Nida 1964: 176)

Nida \& Tarber have stated that dynamic equivalence is to be defined according to the response of the receptors of the message. However, they were aware that "this response can never be identical, for the cultural and historical settings are too different, but there should be a high degree of equivalence of response, or the translation will have failed to accomplish its purpose" (1969: 24).

According to Baker (2004: 63-64), in assessing the centrality of the notion of equivalence, it is necessary to note that:

2. "The notion of equivalence is important because it is used in defining translation itself. This also makes it problematic because it is circular - translation is defined in terms of equivalence and equivalence is at the same time used for assessing and describing actual translation acts.

3. Equivalence is also central in the study of translation because it is closely linked to other important theoretical notions in translation studies; [...]. For example, it is central to the notion of fidelity/faithfulness to an original; which clearly presupposes not only the possibility but the desirability of equivalence. [...]

4. The idea of a unit of translation [...] similarly rests on the assumption of equivalence. Discussions of a unit of translation 
centre on what units are to be considered equivalent (words, clauses, etc.) or what units translators work with in real life in order to produce an 'equivalent' version of the source text".

In the present study I have verified Nida's equivalent effect principle. In the translation of Almodóvar's films, the audiovisual translator needs to focus not only on the form and content of the message, but also on the cultural and social differences between Spanish and American English, and characterological differences between Spaniards and Anglo-Americans. Whenever the equivalent effect has been reached in the subtitles of these films, it is because the translators have achieved the most suitable translation as regards the preservation of the film's original message and flavor. In the absence of this, the target spectator will have been deprived of the real message, cultural characteristics, or original flavor of the ST.

\subsubsection{Norms}

$\underline{\text { Las normas reflejan los valores de un determinado sistema cultural }}$ y guían las elecciones del traductor. El concepto de norma es fundamental en la concepción de la traducción como una actividad comunicativa intercultural: el traductor ha de ser capaz de amoldarse a lo que la sociedad le demanda. (Agost 2005: 26)

The arrival of Almodóvar's films in the US was no bed of roses. The language of most of the characters, the differences between the source and target cultures, the censorship of the US film industry, are some of the factors that have accounted for difficulties and constraints in the translation process. 
En su dimensión sociocultural la traducción se ve sujeta a limitaciones de varios tipos y de distinto grado. Estas limitaciones van mucho más allá del texto origen, de las diferencias sistémicas entre las lenguas y las tradiciones textuales en cuestión, e incluso más allá de las posibilidades y limitaciones cognitivas del traductor como mediador necesario. De hecho, los factores socioculturales influyen, tal vez incluso modifiquen la cognición. [...] Los $\underline{\text { traductores que trabajan en distintas condiciones [...] adoptan con }}$ frecuencia distintas estrategias $y$ al final obtienen productos claramente distintos. (Toury 2004: 95)

Every socio-cultural system has values, thoughts, etc. "que tiende a mantener para conservar intacta su propia esencia en la medida de lo posible" (Gutiérrez 2000: 5). This implies the existence of active directives that govern the TL socio-cultural system and regulate the translation process. Toury (1978: 83) was the first to distinguish between rules, idiosyncrasies and norms, when he affirmed that literary translation was subject to constraints of various types and degrees:

Las normas forman un contínuum graduado en la escala entre los dos polos: unas son más fuertes, y por ello más parecidas a las reglas, otras son más débiles, y por ello casi idiosincrásicas. (Toury 2004: 95)

Norms are understood as a central element in the translation process and they account for the relationships that exist between the rules of the abstract and modeling society and the idiosyncrasies of each translator. These norms constitute the theoretical pillars on which the methodological principles rest. (Díaz Cintas 2004: 25) 
In sociology, norms are "the translation of general values or ideas shared by a certain community - as to what is right and wrong, adequate and inadequate" (Komissarov 1993: 64). The members of that particular community acquire such norms which provide them with the criteria necessary for their socialization. Chesterman (1997: 51) defines norms as memes which are accepted (for whatever reasons - even under threat) by a community as "conducive to behavior perceived as useful: behavior that favors the survival of the individuals concerned". Thus the notion of norm as applied to translation implies a behaviouristic activity, since every translation is produced in a determined sociocultural system, and transferred in order to reach another system that may have nothing in common with the original one. Source and target communities are governed by certain social principles. As a result, these norms will establish what is accepted as a translation in a given culture: "Parece lógico [...] que sean los grupos sociales que controlan la recepción de textos traducidos los que establezcan una serie de normas o instrucciones que el traductor, de acuerdo con su responsabilidad y competencia profesional, deberá asumir en el ejercicio de su labor" (Gutiérrez 2000: $5)$.

In the first place, the initial norm justifies the translator's choice to subject him or herself to the original text and its norms, or to the norms active in the target culture. These initial norms account for either the adequacy or the acceptability of the translation:

Whereas adherence to source text norms determines a translation's adequacy as compared to the source text, subscription to norms originating in the target culture determines its acceptability. (Toury 1995: 57) 
Norms will determine what is considered acceptable in a particular culture, as they "effectively police the borders of what a culture regards as 'legitimate' translation" (Hermans 1995: 18). All decisions made during the translation process "are thus primarily governed by such norms, and not (dominantly or exclusively) by the two language systems involved" (Schäffner 1999: 5). Norms are deeply linked to dynamic and historical parameters that establish their validity, or their disappearance at some point (Rabadán 1991: 56). They operate at every stage in the translating event and are called translational norms. These are divided into two main groups:

2. Preliminary norms "have to do with two main sets of considerations which are often interconnected: those regarding the existence and actual nature of a definite translation policy, and those related to the directness of translation" (Toury 1995: 58).

3. Operational norms take part in the decisions taken during the process itself, and are also divided into two types:

2.1. Matricial norms control the textual segmentation of the linguistic material and its subsequent distribution.

2.2. Textual-linguistic norms establish the translator's choice "respecto a las relaciones que van a funcionar como equivalencia en cada binomio textual TM-TO” (Rabadán 1991: 56).

Rabadán adds another group of norms to Toury's, that is, the reception norm (norma de recepción), which determines the translator's work according to the type of audience the TT is going to be directed at: 
Además, son las que caracterizan y definen el marco de negociabilidad de la comunicación, lo que se refleja en su funcionamiento respecto a la elección el criterio sociolingüístico dominante en la jerarquización del conjunto de relaciones translémicas. (Rabadán 1991: 294)

In addition, Chesterman differentiates between expectancy and professional norms. Expectancy norms refer to what the target community assumes a translation should look like "regarding grammaticality, acceptability, appropriateness, style, textuality, preferred conventions of form or discourse and the like" (Chesterman 1993: 17). On the other hand, professional norms govern the methods and strategies of the translation process itself, and are subdivided into accountability norms, communication norms, and relation norms.

To sum up, it could be said that the study of norms will help "to account for the policy that regulates the whole translation project preliminary norm - as well as the relations that take place in the distribution of the linguistic material when moving from source to target language - operational norms, divided into matricial and textual norms" (Díaz Cintas 2004: 26). Besides, the concept of norm and its application is very important in translation:

Elucidar normas evaluándolas en el contexto en el que han tenido, y tienen, lugar significa poner de manifiesto cómo el capital simbólico que es la cultura, en terminología de Bourdieu, ha sido manipulado a favor de unos intereses u otros, sean éstos económicos, políticos o de otra índole. (Díaz Cintas 2005: 15)

Deeply linked to the concept of norm is the model of descriptive analysis suggested by Lambert and Van Gorp (1985) in which both 
scholars account for "el papel esencial que la comparación de textos traducidos con sus originales tiene a la hora de profundizar en el estudio de la traducción, al mismo tiempo que deploran la ausencia de un modelo de análisis específico y válido que ofrezca las directrices básicas de cómo llevar a cabo la investigación descriptiva" (Díaz Cintas 2001: 99).

The relevant differences between the source and target cultures in this study - Spanish and US -entirely influence the process of translation, as well as the final product. Whereas Spain is an openminded society in which "everything" is allowed, the US is still governed by norms that censure some aspects of life. The censorship that governed Spain during Franco's regime disappeared in the late 1970s, giving way to one of the most permissive societies in existence today. Conversely, the censorship that ruled the US in the $1930 \mathrm{~s}$ is still present in the $21^{\text {st }}$ century - a fact that affects the translation of foreign products arriving on the US film market. In this study, I survey the initial norm followed by Almodóvar's translators - whether they have adhered to the ST norms, or on the contrary, if they have subscribed to the TT ones -, as well as the reception norm that directs the translator's work to the expectation of the target audience.

\subsection{Translatability and Untranslatability}

The debate about whether everything is translatable or not has been a matter of discussion among scholars, at least since medieval times. In the translation process there are circumstances that make translation almost impossible, or at best a real challenge for the translator. One of the main reasons for untranslatability is the differences that exist among languages: "the world's languages all resemble 
infinitely complicated grids, and the basic patterns of these grids scarcely ever coincide" (Payne 1970: 361). Even the most similar languages can exhibit word patterns that can be problematic for the translator. Even in cases in which a word in a SL seems to correspond with another word in the TL, the translator should be on the alert. What is important is that the translator be fully aware of problems of untranslatability during the translation process, as the superficial similarity of the two languages may be deceptive.

Indeed, a good knowledge of both the SL and the TL may not be sufficient to produce a good translation. Knowing the language, its rules, its grammar, and vocabulary are not the only requirements for a translator to be successful. The translator also needs to know the culture of the TL. Nida insists that an awareness of cultural differences among languages is crucial to producing a suitable translation (1975: 66). The cultural presuppositions the translator has to master have to do with "underlying assumptions, beliefs, and ideas that are culturally rooted, widespread, but rarely if ever described or defined because they seem so basic and obvious as not to require verbal formulation" (Ping 1999: 133134). In fact, an unawareness of them may bring about a break in the communication between the source writer/emissary and the target reader/receptor. Time, experience and a good knowledge of both the SL and TL and cultures are the key factors for producing a good translation.

Some scholars defend the idea that everything can be translated. Others maintain that texts are "more or less translatable, rather than absolutely translatable or untranslatable" (Catford 1965: 93). The same idea is shared by Rabadán (1991: 110): for her a descriptive and comparative analysis of the products of translation in both acceptability and adequacy - demonstrates that there is no totally untranslatable element, but rather elements that are more or less translatable. 
Catford distinguishes between linguistic and cultural untranslatability. Linguistic untranslatability occurs typically where "an ambiguity peculiar to the SL text is a functionally relevant feature - e.g. in SL puns" (1965: 94), and the failure to find a TL equivalent is due to the differences between the SL and the TL. On the other hand, cultural untranslatability is usually less 'absolute' than linguistic untranslatability (1965: 99). But he goes further, stating that "in many cases [...] what renders 'culturally untranslatable' items 'untranslatable' is the fact that the use in the TL text of any approximate translation equivalent produces an unusual collocation in the TL $[\ldots]$ and this would be a type of linguistic untranslatability" (1965: 101).

Besides, within the framework of a linguistic theory of translation, Catford distinguishes between a textual equivalent - "any TL text or portion of text which is observed on a particular occasion [...] to be the equivalent of a given SL text or portion of text" - and a formal correspondent - "any TL category (unit, class, structure, element of structure, etc.) which can be said to occupy, as nearly as possible, the 'same' place in the 'economy' of the TL, as the given SL category occupies in the SL" (1965: 27).

In addition, Lefevere (1990: 25) affirms that untranslatability seems to have "a lot more to do with the absence of poetological equivalents than with the absence of semantic or morphosyntactic equivalents".

When the translation is difficult because of huge differences between both languages, or to the inexistence of some realia in one language or the other, the word adaptation becomes salient:

$\underline{\text { Nosotros creemos que siempre es posible traducir pero sabiendo }}$ que toda traducción se desliza por una pendiente que puede alejarnos del logos porque también puede acercarnos al sema: 
habrá vivencias que representen una dificultad traducirlas, porque puede que en la otra lengua no existan esas vivencias, pero siempre se puede recurrir a modulaciones o adaptaciones. (Blanco 1990: 42)

Bernal (2002: 20) shares the opinion that there is nothing untranslatable, and that despite different cultures all over the world, all the members that integrate them are human beings, and as such, their behaviors may be understandable across cultures. As regards idioms, slang, etc., they all have their equivalents, "solo tendremos que acceder a la fuente adecuada" (ibid).

Cultural references comprise what is known as "areas de inequivalencia interlingüística" (interlinguistic inequivalence areas) (Rabadán 1991: 109-173):

Serían todas aquellas áreas anisomórficas o asimétricas entre un par de lenguas que de modo recurrente provocan una limitación en la aplicabilidad de la equivalencia, $y$ por tanto su transferencia directa implica algún tipo de distorsión, desvío o pérdida en la Lengua Meta. (Samaniego 1995: 55)

For most scholars these cultural differences are the main constraints in the process of translation, which make it impossible to maintain the originality of the ST in the TT:

Por muy fieles que intentemos ser, nos encontraremos, sin embargo, en situaciones en las que la decisión habrá de ser en cualquier caso inadecuada. Si queremos destacar en nuestra traducción un rasgo importante del original sólo podemos hacerlo dejando en segundo plano otros aspectos o incluso reprimiéndolos del todo. (Gadamer 1977: 465) 
Now there are translators who opt for a free translation when they come across cultural elements. However, the choice of a free interpretation usually turns out to be the main reason for the production of incorrect translations, for example in cinematographic translation:

At times the translator has to free himself from the exact words and try to capture the spirit of what the audience/readers will hear or read. How many people outside the U.S.A. had ever heard of the two outlaws who were the protagonists of the film Butch Cassidv and the Sundance Kid? Very few and, knowing this, the Spanish dubbers called their version Dos hombres y un destino. (White 1993: 26)

Indeed, the different deliberations among scholars about translatability and untranslatability simply indicate that the process of translation is a subjective one. It depends entirely on the translator, whose knowledge, experience and strategies pervade both the process of translation and its final product.

In this study, I have come to the conclusion that, as Rabadán affirms, there is nothing untranslatable, only elements that are more or less translatable. The most appropriate translation, one that will produce the same effect on both source and target audiences, depends entirely on the translator's knowledge of SL and TL and cultures, as well as on the strategies used.

\subsection{Domestication and Foreignization}


In a 1813 lecture on the different modes of translation, the theologian and philosopher Friedrich Schleiermacher stated that there were only two possible methods: "either the translator leaves the author in peace, as much as possible, and moves the reader towards him; or he leaves the reader in peace, as much as possible, and moves the author towards him" (Schleiermacher 1977). He was talking about domestication versus foreignization.

Domestication was defined by Venuti as "an ethnocentric reduction of the foreign text to target-language cultural values, bringing the author back home" (1993: 210). He implied a translation characterized by a clear and fluid style acceptable to the receptor of the target culture, "anulando todas las posibles dificultades derivadas de su carácter extraño o extranjero" (Zaro 2001: 55). Therefore, according to Venuti (1995: 5), this translation process is for any reader "the narcissist experience of recognizing his own culture in a cultural other, enacting an imperialism that extends the dominion of transparency with other ideological discourses over a different culture to the cultural and economic hegemony of target-language publishers".

On the other hand, foreignization is "an ethnodeviant pressure on those values that register the linguistic and cultural difference of the foreign text, sending the reader abroad" (Venuti 1993: 210). It implies the opposite process, that is, translating a text while maintaining the "strange nature" in the TT, even if it involves the selection of an obscure and unclear style that may represent an obstruction to the target receptor's understanding.

Domestication is the method of translation that predominates in the dubbing process that is oriented to the target culture. This domestication operates fundamentally through synchronization, “escondiendo la traducción y creando la ilusión de que la versión doblada es la única versión original" (Goris, in Ballester 2001b: 221). 
Domestication operates "in graphic signs, in the pronunciation of foreign words or proper names, and in socio-cultural references" (ibid). On the other hand, foreignization is used with the subtitling method: here, the spectator listens to the original soundtrack of the film while reading inserted subtitles written in the mother tongue, or any other language the spectator knows. It is clearly a more visible process of translation. This visibility of the work of translation contrasts with the invisibility of the translation process in dubbed versions. In the dubbing method domestication directs the resulting product that, in Venuti's opinion, creates a fake appearance of flow and closeness to the target culture (Zaro 2001: 57).

However, Díaz Cintas (2005: 17) does not fully agree with Venuti's view on audiovisual translation, as:

[...] Domesticación y extranjerización son dos conceptos elaborados en el seno de la teorización sobre la traducción literaria que, debido a su énfasis en la dimensión lingüística, pueden funcional con mayor o menor éxito en el mundo literario, pero resultan a todas luces insuficientes en la TAV, en la que el valor de la imagen suele estar jerarquizado por encima del de la palabra. Si queremos que los postulados de Venuti sean funcionales en nuestro campo de trabajo es necesaria, pues, su reelaboración.

Any source text belongs to a specific socio-cultural medium and fulfills a range of codes governing fashion, social relations, aesthetic concepts, linguistics, writing, literary norms, etc. In other words, texts cannot be disassociated from their contexts. It is in the process of translating films that these problems become even more acute. For cinema consists of different elements that are present at the same time images, noises, music, oral language -, and the meaning of the film is 
created by means of the relations established among all these elements. Every film is linked to a specific socio-cultural context:

L'importance de ce paramètre culturel est certes variable, dans les images, parce que le comportement des protagonistes - membres de la société en question, mais aussi dans le discours des personnages où certains éléments linguistiques renvoient directement à des références culturelles connues du spectateur d'origine. (Tomaszkiewicz 2001: 239)

Toury gives different terms to the same two strategies:

- Acceptable translation is "oriented towards the norms of the target language and culture" (Agost 2004: 71)

- Adequate translation is "oriented towards the norms of the source language and culture" (Agost 2004: 71)

\subsection{Language, Culture and Translation}

Cuántas veces hemos entendido cada una de las palabras de una frase en inglés pero no hemos entendido lo que aquello quería decir. Se puede haber adquirido una competencia muy alta en la segunda lengua pero no haber incorporado el conocimiento cultural necesario e indispensable que comparten todos y cada uno de los hablantes de esa comunidad lingüística y que les permite comunicarse entre ellos. (Iglesias 1998: 127)

Language, which consists of signs that correspond to specific ideas, is an instrument of communication among people. There is a strong link between culture and language, the former finding its expression in the latter, and as Roland Diot has stated, "what makes 
one nation love is hardly what turns on another nation". In 1949 Trager pointed out that "language is one of the systematic arrangements of cultural items that societies possess". Santoyo (1994: 142) has distinguished between the concepts of civilization and culture, defining the latter as "aquello que nos hace 'nosotros', aquello que se 'disfruta' en monopolio (por eso está adjetivada), que $\underline{\text { nos diferencia, } y \text { por lo tanto carece de parangón allende nuestra }}$ colectividad humana e idiomática".

There have been numerous approaches to the notion of culture, mostly from anthropology. The growing recognition of the importance of culture as it exists in other disciplines - linguistics, language learning, translation - has led to more functional definitions of culture, as for instance "a bundle of patterns of behavior, habits of conduct, customs, laws, beliefs, and instinctive responses that are displayed by a society" (Blatchford 1986/1990: 130). It is the origins of a person and of a community that determine their language, culture, and life style. From the point of view of cognitive anthropology culture is seen as "shared knowledge", that is, what all members of a community should know in order to behave, act, and interpret their experiences in a specific way (Holland \& Quinn 1987: 4). From this cognitive perspective, culture is not limited to customs, traditions and material objects of a specific community; rather it covers a whole range of knowledge shared by its members. The structure of this common knowledge helps the members of a community understand the world in which they live, as well as the way they have to behave in that world. Language and culture are set up reciprocally: human beings form their own vision of the world through their experience and discourse. At the same time they abstract a synthesis of such vision in order to present it by means of linguistic signs. 
Von Humboldt connected language and culture, language and behavior. For him language was dynamic, the expression of "the culture and the individuality of the speaker who perceives the world through language" (Snell-Hornby 1988: 40). For Snell-Hornby (1988: 42) language is an integral part of culture, and the translator "needs not only proficiency in two languages, he must also be at home in two cultures [...]; he must be bilingual and bicultural (cf. Vermeer 1986)". Thus it is the translator's knowledge, proficiency and perception that will determine both, the production of the TT and the understanding of the ST.

The importance of the cultural component in the language is undeniable:

The fact that language is culture and culture is language is brought out most sharply when one tries to replace his language with another. A person can change his country, his citizenship, his religion, his politics, his philosophy, and now even his sex more easily and smoothly than his language. It is the very sound of the language that sings the culture it represents, and this is the oral aspect that is lost in translation and this may be what Robert Frost was thinking or feeling when he defined poetry as what's lost in translation. (Rabassa 1991: 43-44)

Because cultural differences between $\mathrm{ST}$ and TT receptors are of such significant importance in the process of translation, they can become problems for the translator. For the process of translation, the translator is not only putting the content of the SL into the TL, but also adapting the text from the source culture to the target culture. This change of focus in recent theories whereby translation is seen not only as a linguistic transfer, but also as a cultural 
transfer, has led Vermeer to affirm that translation is an intercultural transfer, which involves a "bicultural translator" if there is to be a successful TT. Thus, the translator is expected to have a high degree of proficiency in both languages, as well as a perfect knowledge of both source and target cultures (to be 'bilingual' and 'bicultural', as stated above).

In the 1950s Casagrande affirmed that, "in effect, one does not translate languages, one translates cultures". Bassnett, Lefevere and Kussmaul point out that translation takes place between two cultures, intead of between two languages, and support a cultural focus in translation in which "el texto no es tanto una manifestación lingüística como un acto comunicativo con una función y que además está impregnado del contexto sociocultural en el que tiene lugar" (Iglesias 1998: 126). The translator "realiza el traslado de un conjunto cultural expresado lingüísticamente hacia otro campo cultural no del todo similar al primero" (Sánchez 2000: 686). Every individual is said to have a cultural competence that varies according to race, gender, age, social condition, etc. This presupposes that even the receptors of the $S T$ perceive its cultural allusions in terms of cultural competence. Indeed, if the translator is unable to transmit the cultural references of the $S T$ into the $T T$, with the necessary adaptations, the target reader may not be able to understand the translation.

As regards audiovisual translation, most countries have experienced the arrival of foreign material in increasing quantities. Every item of this foreign material has socio-cultural features of crucial importance that require skillful translation in order for the message to be transmitted. Familiarity with language and culture are what makes translation a complicated intellectual skill. 


\subsection{The Translation of Humor}

Que signifie le rire? Qu'y a-t-il au fond du risible? Que trouverait-on du commun entre une grimace de pitre, un jeu de mots, un quiproquo de vaudeville, une scène de fine comédie?

(Henri Bergson, Le rire).

\subsubsection{What is Humor?}

Different disciplines - sociology, psychology, anthropology, literature, linguistics, medicine, religious studies, and philosophy - have tried to provide a theory and definition of humor. However, to date they have only provided theories, and some of them more convincing than others, but none of these theories "monopolizes the truth" (Veatch 1998: 162). Zabalbeascoa states the difficulties involved in defining as well as studying humor. He has tried to give a possible definition of humor as "todo aquello que pertenece a la comunicación humana con la intención de producir una reacción de risa o sonrisa (de ser gracioso) en los destinatarios del texto" (2001a: 255). Attardo \& Raskin (1991) outline a general theory of verbal humor by means of the script-based semantic theory of humor by Raskin (1985), and the five-level model of joke representation (Attardo 1989), in order to produce "a much more general, powerful, and versatile concept of joke invariance" (1991: 329). This theory is outlined as:

A general and essentialist theory of verbal humor in the sense that it addresses the 'what' question, that is, 'what if humor?'. It does not 
address a number of other possible questions such as 'why does humor exist?' or 'how do people use humor?'. Those questions are handled by special theories of humor. (1991: 330)

Humor is a cognitive process deeply rooted in culture. As social norms belonging to cultures are modified with the passing of time, so is humor. Nash (1985) states that humor characterizes the interaction of persons in situations and in cultures, and our response to it must be understood in that broad context. For Vandaele (1997: 237-238) the product of humor, i.e. physical laughter, or smiling, "makes the ordinary language concept of humour usually unquestioned". It is obvious that not everybody laughs at the same things, and not everybody finds the same things funny. As for laughter itself, "the physiological processes involved in the production of laughter [...] are identical in men and women the world over" (Chiaro 1992: 4), which gives rise to the idea that laughter is universal. But what is it that causes laughter? And is laughter universal?

There are certain situations that cause laughter in everybody: who has not laughed at somebody tripping on a banana peel? However, with language, certain restrictions apply. What may be very funny in one language does not necessarily have the same effect in another: "the concept of what people find funny appears to be surrounded by linguistic, geographical, diachronic, socio-cultural and personal boundaries" (Chiaro 1992: 5). In other words, what is funny in Spain may not be funny in Iceland, for instance. Different cultures do not laugh at the same things, and not even people from the same culture laugh at the same things. What a person finds funny will depend mostly on personal experiences and principles, personality and culture.

Chiaro (1992: 5) refers to the concept of "socio-cultural restrictions", and groups them in three categories: geographical, historical and intellectual, stating that if somebody does not get a 
joke or find it funny, that does not mean that the person in question has no "sense of humor". On the contrary, not getting a joke has to do with the sender and recipient not sharing the necessary amount of knowledge; indeed, the recipient may not be aware of the object of the joke. Imagine, for example, a person who has lived abroad for some time: despite trying to keep in touch with the life and happenings in the home country, he or she will possibly be "out of date" regarding various matters. The importance of shared knowledge between sender and recipient is important for a joke or a funny comment to be understood (Chiaro 1992: 11)

There are jokes and comments that are funny because they break linguistic rules. When this happens, the knowledge of the recipient "requires a high standard of proficiency to be able to deal with ambiguities and hidden traps of the language" (Chiaro 1992: 13). This, of course, implies that the recipient of a joke who is not highly proficient in the language of that joke or comment will have trouble understanding it. The sender naturally expects the recipient to have sufficient linguistic and socio-cultural knowledge to be able to recognize the linguistic rules that have been broken in order to create the humorous effect. If the recipient shows a lack of knowledge of sexual matters (when it comes to sexual jokes), or cultural facts, or has certain linguistic limitations, the sender will not elicit laughter from the recipient.

Along the same line, Norrick (1989: 118) states that humor depends not only on "some funny stimulus", but also factors such as the audience, the situation and the cultural context, all of which are necessary for a humorous situation, comment or text to be successful. The role of the audience is of primary importance in the transmission of humor, since for verbal humor to succeed the sender requires "an audience sensitive to its genre and linguistic conventions" (ibid). When dealing with audience response, it is important to mention the different reactions between men 
and women. There are differences in gender as regards the appreciation of humor ${ }^{1}$ : a man will probably respond to a joke or comment in a very different way from a woman, regardless of the content of the joke. Jokes are divided into different sections depending on the "situation" of the joke, in other words, "the 'props' of the joke: the objects, participants, instruments, activities, etc.” (Attardo 2002: 179).

\subsubsection{Humor Appreciation}

There are numerous studies dealing with gender differences in humor appreciation, such as Mundorf \& Bhatia 1988, Herzog \& Bush 1994, Herzog \& Karafa 1998, Johnson 1992, and Leventhal \& Cupchik 1975, among others. Johnson (1992: 575) comes to the conclusion that whereas women seem to express a preference for nonsense, silly, rolereversal (in which the victim is a man) and disease disparagement humor, men seem to prefer aggressive, sick, word-play jokes disparaging men, and irreverent humor. Women seem to prefer disease disparagement humor (vs. irreverent humor), which indicates that "women are less comfortable directing hostility toward authority than they are casting it downward to the less fortunate" (ibid). Mundorf et al. (1988: 231) indicate that gender differences apply to sexual and hostile humor, and agree with the idea that the person whose gender is being attacked does not enjoy the joke in the same way as the person of the opposite sex. Along the same lines, men seem to appreciate sexual humor more than women, a fact related to Freud's idea that sexual humor "is the province of men who, preferably in the company of other males, indulge in poking fun at females and their sexuality" (Mundorf et al. 1988: 232).

\footnotetext{
${ }^{1}$ A subject's or group's reaction to humor has been called "individual appreciation of humor" (in Duchaj 1999)
} 
It is obvious that both males and females may find a joke that pokes fun at the opposite sex, rather than at one that ridicules their own sex, more humorous. However, there is evidence that some males do laugh at jokes poking fun at the male sex, and this is explained in terms of "rivalry": men usually perceive other males as "potential rivals and their debasement serves the self-enhancement of the teller or of the audience of the joke" (ibid). On the other hand, women usually dislike sexual humor, since most sexual humor tends to victimize the female gender. Nevertheless, no gender differences can be perceived unless sexual humor is sexist, and men and women enjoy it in the same way. There are also gender differences regarding hostile humor ${ }^{2}$ : in that respect, women find hostile humor less funny than men do. Disposition theory (Zillman 1983) probably accounts for it, as it predicts that "females enjoy hostile humor more when a male is victimized, and males would laugh more readily at a female victim" (Mundorf et al. 1988: 233).

As for nonsense humor, men are supposed to enjoy it more than women do. Freud links this enjoyment to the idea that men enjoy superficial, unchallenging and "easy" humor. But women are still more sensitive than men about topics such as sexuality, hostility and sickness in jokes. On the other hand, men are more open-minded and less prone to make victims of jokes. It seems that women get more involved in a joke, while men simply listen to it and then draw on its humor. However, not many people take pleasure in a joke in which their own sex is being ridiculed. But there are some who simply enjoy jokes, and keep themselves from attaching any personal feelings to them.

\subsubsection{The Translation of Humor}

\footnotetext{
${ }^{2}$ Hostile humor could be defined as that humor in which somebody is made the "butt" of the joke (in Mundorf et al. 1988: 233)
} 
El humor es complicado de traducir, porque, si bien podemos reconocerlo y entenderlo cuando nos topamos con él, también sabemos que en muchos casos, para hacer válida aquella broma en otro idioma hemos de presentarla de un modo distinto. (Bernal 2002: 80)

Humor $[\ldots]$ is a phenomenon that is deeply rooted in a cultural substratum ("culture" understood in the anthropological sense of the term). In other words, humor is frequently a captive of its own language and culture. This represents one of the biggest challenges that the translator must overcome. (Bravo 2002: 202)

Many scholars have noted the strong link between culture and language. It frequently happens that a kind of humor that belongs to a specific culture or country may be of no interest to another culture. Therefore, translating that particular type of humor from one culture and language into another may bring with it the challenge of an "added requirement that the translation must be better than the original" (Nilsen 1989: 123). (Adrjan \& Muñoz-Basols 2003: 242)

\section{When it comes to the translation of humor, opinions are many and}

\section{sundry:}

The translation of humor is a stimulating challenge. It requires the accurate decoding of a humorous speech in its original context, the transfer of that speech in a different and often disparate linguistic and cultural environment, and its reformulation in a new utterance which successfully recaptures the intention of the original humorous message and evokes in the target audience an equivalent pleasurable and playful response. (Leibold 1989: 109) 
Raphaelson-West compares the translation of humor to the translation of poetry, and states that "like poetry, it [the translation of humor] will often need to be explained and used for instruction purposes; however, in the case of similar cultures and languages it is often possible to do an effective translation" (1989: 129). She asserts that the translator should bear in mind that the TT will not always be as humorous as the source one. In such cases what the translator needs to do is "to keep the cultural content in mind, to locate the humorous aspect or aspects of the text, and to try to explain or duplicate this aspect" (1989: 140). Santoyo (1994: 147) maintains that when it comes to the translation of humor:

O pasamos, como traductores, a una recreación imitativa (y ése ya es un proceso distinto del de la traducción), o bien, destruida la razón del humor en la nueva versión, acabamos explicando lo imposible a pie de página.

According to Zabalbeascoa (2001b: 256), “un traductor deberá estar atento a la posible existencia de elementos humorísticos en cualquier texto de partida, y, una vez detectados, deberá decidir sobre la importancia que tienen y la función que cumplen, y luego deberá decidir sobre la manera en que va a tratarlos según las características y la función que se hayan determinado para el TM". Apart from changing from one language into another, the translator has to be able to translate cultures. Cultural humor is humor "que se apoya en datos privativos, en principio, de la cultura de origen, sean éstos nombres, lugares, hechos históricos, costumbres, etc."(Bernal 2002: 85). The socio-cultural elements contained in a joke or humorous comments are usually so culturallybound to a specific community that it may not be funny in another community or country (Chiaro 1992: 78). A sexual joke in Spanish that praises the masculine "attributes", for instance, may not sound witty 
when translated for a US audience. Even in countries that are close and have similar cultures, the same joke may not have the same acceptance, even though its translation may be close to perfect:

When dealing with another joke 'universal', sex, there are rather more complex difficulties to be faced when attempting to translate. Despite the fact that most western cultures see sex as humorous subject matter, they do so in slightly different ways. (Chiaro 1992: 79)

There is also humor related to events and people of different countries: "different ethnic and national groups choose different stereotypical targets for their aggressive humour" (Attardo 2002: 186). In these jokes, the targeted group is made fun of because of some particular features: e.g., in Spain people poke fun at the Catalonians because of their stinginess; in the US, Polish people are considered stupid. Thus even if the recipient knows the language of the joke, but is not aware of the particular features of the targeted groups, the joke may not have any effect. In other words, translating becomes more difficult "when sociocultural restraints are combined with linguistic restraints" (Chiaro 1992: 84).

Humor does not function in isolation: "it is not only rooted in its co-text $[\ldots]$, but also in socio-cultural, linguistic and even personal contexts. The universality of humor is relative" (Díaz Cintas \& Remael 2007: 214). As for Vandaele (2002: 165):

It is clear [...] that: we may not always be able to grasp the sender's intentions; we may have our own (conscious or unconscious) agenda while grasping intentions; many other contextual elements play a role in the interpretation process; original contexts may be absent; new 
contexts may emerge continuously; the humorous function of a text may be combined with other textual functions. This means that a translator of humour has to make decisions.

Some scholars have argued about "untranslatability" (Jakobson 1959; Popovic 1976), saying that "any translation is by its very nature an interpretation of the source text rather than its perfect reflection" (Chiaro 1992: 92). The implication is that in confronting the impossibility of translation, every so-called "translation" will be nothing more than an interpretation of the ST. Chiaro (1992: 93) mentions the 'invariant core' as an indispensable element for the translator of humor. That is, in order to assure a successful translation, the core of the joke needs to be identified.

As regards the translation of comic plays or films, the translator may render a difficult joke in a totally different way in the TL (Chiaro 1992: 95), rather than give a literal translation requiring an explanation. This replacement of the SL joke by a completely different one in the TL will serve the dynamics of the process, in contrast to the literal translation that will be a "faithful, but interactionally poor translation" (ibid).

The translator of humor faces more boundaries and constraints than any other type of translation, except perhaps poetry. The constraints in the translation of humor, together with the boundaries and difficulties present in audiovisual translation, make the translation of humor in films even harder:

For translators the first challenge obviously consists in understanding what is humoristic in the source text, recognizing the clues, the incongruities, but also the comic repertoires linked to particular 
humoristic genres, or commonly used tricks such as exaggeration, or understatement. Then they have to find a way of transferring the perceived humour into the target text and reformulating it into a new utterance that will hopefully provoke an equivalent effect, in casu laughter, a smile, or maybe a smirk. Interpreting the source text humour is the first step; evaluating how the target viewer will see and interpret a particular instance is the next; rephrasing the humour is the final outcome. (Díaz Cintas \& Remael 2007: 214)

Audiovisual translation is unquestionably difficult; as a first step, the audiovisual translator of humor should be aware of some guidelines and follow them:

2. Accept the untranslatability of the SL phrase in the TL on the linguistic level

3. Accept the lack of a similar convention in the TL

4. Consider the range of TL phrases available with regard to the presentation, status, age, sex of the speaker, as well as his relationship to the listeners and the context of the meaning in the SL

5. Consider the significance of the phrase in its particular context - i.e. as a moment of high tension in the dramatic text

6. Replace in the TL the invariant code of the SL phrase in its two referential systems: the particular system of the text and the system of the culture out of which the text has sprung. (Chiaro 1992: 86-87)

As far as subtitles are concerned, translating humor requires a "sixth sense" as well as creativity, but it also has to do with establishing priorities: 
Humour can occur on different levels: it can arise from the interaction between word and image, or a play on words, but it can just as well be an integral part of the story plot, reside in experiments with genre features and intertextuality, etc. Some instances will therefore be much easier to translate than others, and their importance for the programme at hand will also vary. (Díaz Cintas \& Remael 2007: 214-215)

Thus the goal of the audiovisual translator is to maintain the humor present in the film, and to try to create a successful translation. If the target audience laughs at the same moments as the original audience does, the translation will be successful. What is both interesting and significant is that the humor present in Almodóvar's films does not usually come from jokes, but rather from the dialogues, the appearance of the characters, or the particular situations. His films are full of cultural references the translations of which do not usually convey the same humor of the original, as the emotional and humorous value of some of the comments and situations cannot be successfully transmitted.

\section{Audiovisual Translation}

\subsection{The Term "Audiovisual Translation"}

Por traducción audiovisual nos referimos a la traducción, para cine, televisión o video, de textos audiovisuales de todo tipo (películas, telefilmes, documentales, etc.) en diversas 
modalidades: voces superpuestas, doblaje, subtitulación e interpretación simultánea de películas. (Hurtado 2001: 77)

La traducción audiovisual es una variedad de traducción que se caracteriza por la particularidad de los textos objeto de la transferencia interlingüística. (Chaume 2004: 30)

The birth of audiovisual translation can be traced back to the birth of cinema itself: "los pioneros americanos de la época muda fueron los primeros en darse cuenta de que, para exportar sus productos, tenían que traducir aquellos carteles llenos de puntos suspensivos que aparecían entre un plano y otro de Rodolfo Valentino" (Piastra 1989: 344). However, it is worth mentioning here that "el ejercicio profesional de la traducción cinematográfica es tan antiguo como la propia cinematografía, esta actividad, en cuanto a disciplina académica, no empezó a tener una presencia tímida en las universidades españolas hasta 1993" (Bravo 2005: 124).

In 1960, the publication in Babel of a monographic issue dealing with cinema translation was regarded as the most important moment in the field of audiovisual translation. The papers in this issue were basically descriptive, "con un enfoque predominantemente profesional" (Mavoral 2001: 22). The research that followed included audiovisual translation in the field of general translation studies. It was not until two decades ago that theoretical studies were developed in the field of translation. In the 1980s Canada was dealing with "film translation", but after that not much study was done. In the Arabic countries it is extremely difficult to find any work in this field since very little has been done. South America does not have many studies, as opposed to Russia, where a lot has been written exclusivelv in Russian. It is still stated that every 
bit of research focusing on audiovisual translation has its origin not in translation studies, but in other fields. Many scholars mention the lack of detailed research of any significance in the field of audiovisual translation.

In 1990, there was only one article published by Spanish researchers, by Mayoral et al. (1988), on constrained translation. Also, there had been only one conference on screen translation that took place in Stockholm in 1987. Besides, "no se había leído todavía ninguna tesis doctoral $[. .$.$] ni se había publicado ninguna$ monografía $[\ldots]$ ni ningún libro colectivo; [...] no había ninguna asignatura de traducción audiovisual en programas de doctorado, másters o licenciatura [...]" (Bravo 2005: 124).

However, since 1995 onwards this situation has changed considerably:

1995 was the 100 -year anniversary of the cinema. The Council of Europe wanted to celebrate it and agreed to host a forum on audiovisual communication and language transfer. (Gambier 2003: $\underline{171)}$

From that year on, colloquia, seminars, conferences, etc. have been taking place:

Los estudios sobre traducción audiovisual han vivido en los últimos años una eclosión que hace justicia con el olvido reiterado que ha sufrido esta modalidad de traducción desde los inicios de la reflexión traductológica. (Chaume 2002a: 215)

Some of the key factors that have produced a growing interest in audiovisual translation were the "parallel booming of the so-called 
new technology $[\ldots]$, and language policy and language awareness, especially in Europe" (Gambier 2003: 171).

It is surprising to observe that research on audiovisual translation is still in its initial stages, even though mass communication nowadays has an important and significant position:

La traducción fílmica no deja de ser, para un cierto círculo de traductores y teóricos de la traducción, sino una manifestación marginal y periférica a la que no merece la pena dedicar esfuerzo investigador alguno. (Díaz Cintas 2001: 93)

Nevertheless, there seems to be a gradual change in analytic studies that “enfocan el objeto de estudio desde perspectivas más pluralistas, innovadoras e interdisciplinares, lo que en consecuencia conduce a resultados más variados y fructíferos y otorga una mayor visibilidad a esta práctica traductora" (ibid). Bravo affirms that "los últimos años han sido testigos de una gran efervescencia en esta área de estudio: se han leído varias tesis doctorales y un número ya importante de trabajos de investigación tutelados, se ha publicado algunas monografías, $[\ldots]$ y unos pocos libros colectivos; han seguido apareciendo artículos sueltos en libros y en revistas de investigación; y va creciendo el número de cursos que se imparten a todos los niveles [...] y de reuniones científicas que giran en torno a esta área de estudio, $[\ldots]$ al tiempo que ha aumentado extraordinariamente la popularidad de esta modalidad de traducción" (2005: 124-125). Also, as Chaume notices, from a curricular point of view audiovisual translation "should take its place in today's syllabus, not just because it responds to one of the translation activities with the most rapidly growing volume of work, one ever more present in our daily lives, but also because of its didactic potential, as an example of an exercise in translation" (2002b: 2). 
From the beginning there were problems of terminology in this growing field. Some scholars used the term "Film Translation", but films were not being translated but rather dialogues. In the early $20^{\text {th }}$ century film translation received the name of "Language Transfer", leaving aside the audiovisual dimension. "Audiovisual Translation" was considered too French a term, and "Film Adaptation" started to come into its own despite its ambiguities. Later on some scholars opted for "screen translation", but the term was said to be misleading. "Translating for the Media" was thought not to be appropriate, as the term 'media' includes many things, such as newspapers and magazines that have no relation with this growing field. "Multimedia Translation" was also considered to be misleading because of the term 'multimedia'. Probably the best option was "Audiovisual Translation", as it included multisemiotic texts (pictures and sounds). The study of translation in the field of television and cinema was given the name of "Cinematographic Translation", as well as "Constrained Translation", defined as "todas aquellas modalidades de transferencia interpolisistémica donde intervienen otros códigos además del lingüístico" (Rabadán 1991: 149). Finally, the terms "Audiovisual Translation" and "Screen Translation" were institutionalized. Nevertheless, different scholars show their own preferences ("audiovisual translation", for instance), when referring to the widely used terms "screen translation" and "film translation". In his book, Cine y Traducción, Chaume accounts for the variety of terms used by researchers:

Además de traducción audiovisual, que es ya la acepción con mayor difusión en España, existen o han existido los términos film dubbing (Fodor, 1976), constrained translation (Titford, 1982), film translation (Snell-Hornby, 1988), y traducción fílmica (Diaz Cintas, 1997), screen translation (Mason, 1989), film and TV translation (Delabastita, 1989), 
media translation (Eguíluz et al., 1994), comunicación cinematográfica (Lecuona, 1994), traducción cinematográfica (Hurtado, 1994-1995), multimedia translation (Mateo, 1997), y los conocidos (y parciales) doblaje y subtitulación (2004: 30)

Díaz Cintas \& Remael account for this fluctuation in terms as a reflection on the current audiovisual market. In addition:

Far from representing a barrier to communication, it could be interpreted as a clear sign of the desire of many academics to maintain an open and flexible approach to our subject of study; one that can assimilate and acknowledge the new realities emerging in the translation world. (2007: 12)

According to Delabastita (1989: 196), “audio-visual communication implies that both the acoustic channel through air vibrations, and the visual channel through light waves, are simultaneously utilised". Consequently, it is by means of acoustic and visual channels that the message of the film reaches the audience. Verbal signs - such as the title of a film or program - are transmitted through visual means; on the other hand, verbal and non-verbal information - a noise in the film - is transmitted through acoustic means.

Nowadays, audiovisual translation is gradually changing due to:

[...] El incremento espectacular de la demanda y la oferta de productos audiovisuales, que se manifiesta en:

a) La multiplicación de cadenas de televisión regionales y locales.

b) El incremento de actividades como la enseñanza a distancia.

c) La aparición de las plataformas digitales, la televisión a la carta, etc.

d) La extensión de la televisión por cable. 
e) La extensión de las emisiones de televisión por satélite. (Mayoral 2001: 20-21)

Still, some scholars regard audiovisual translation as not a proper form of translation because of all the temporal and spatial limitations of the medium which inevitably restrain the final product (Díaz Cintas \& Remael 2007: 9). Instead, they prefer to talk about adaptation arguing that:

$[\ldots]$ Subtitling $[\ldots]$ is constrained by the respect it owes to synchrony in these new translational parameters of image and sound $[\ldots]$ and time [...]. Subtitles entail a change of mode from oral to written and resort frequently to the omission of lexical items from the original. [...] The dimensions of the actual screen are finite and the target text will have to accommodate to the width of the screen. [...] This means that a subtitle will have some 32 to 41 characters per line in a maximum of two lines. (ibid)

\subsection{Two Main Methods of Audiovisual Translation in}

\section{Films: Dubbing and Subtitling}

The translation of a film can be achieved by two main methods, dubbing or subtitling. Subtitling mainly consists of the "sobreimpresión o sobre-proyección en la película de un texto escrito que traduce lo que se oye en la pantalla en la lengua original. La duración de los subtítulos se hace coincidir con la de sus correspondientes palabras pronunciadas" (Mayoral 1993: 50). Besides, subtitling is regarded as "la única manera de respetar y conservar intactos sus diálogos [de la película] y su sonido original" (Leboreiro \& Poza 2001: 315). Nevertheless, it is important to 
bear in mind that subtitles "no constituyen en todos los casos una transcripción fiel del diálogo original, sino una adaptación que, en muchos casos, debe sacrificar parte de la información” (ibid).

On the other hand, dubbing ${ }^{3}$ is "la grabación de una voz en sincronía con los labios de un actor de imagen o una referencia determinada, que imite lo más fielmente posible la interpretación de la voz original" (Ávila 1997: 18), or "la traducción y ajuste de un guión de un texto audiovisual y la posterior interpretación de esta traducción por parte de los actores, bajo la dirección del director de doblaje y los consejos del asesor lingüístico, cuando esta figura existe" (Chaume 2004: 32). Dubbing is also characterized by the replacement of the original soundtrack by a new soundtrack in the TL. This replacement brings into question the fidelity of the translation (Törnqvist 1995: 49). Synchronicity plays a vital role here, as the new soundtrack has to be synchronized with the lip movement of the characters. If this is not completely achieved, the dubbed version will probably not be successful.

El criterio que se utiliza para decidir si una película se dobla o se subtitula suele estar basado en razones económicas: el cine comercial, especialmente el norteamericano, se suele doblar para que tenga mayor repercusión y obtenga mayores $\underline{\text { beneficios en taquilla; el cine de arte y ensayo, más minoritario, }}$ $\underline{\text { se suele subtitular en salas de menor tamaño y menos }}$ concurridas. (Chaume 2004: 34)

The differences between these two methods are quite prominent:

a) Dubbing costs are relatively higher than subtitling:

\footnotetext{
${ }^{3}$ The general term dubbing may cover different kinds of revoicing: voice-over, narration and free commentary (O’Connell 1998: 65-66).
} 
Dubbing is a far more complex and expensive business than subtitling [...]. The differences in cost are normally reckoned to be roughly $10: 1$, which means that, expressed in European currency terms, it costs on average ECU 20,000 to produce one hour of lip-synchronised dubbing as opposed to ECU 2,000 for subtitling the same material.[...] If one elects to dub, there is almost always a built-in calculation that one will be able to secure a much larger audience. (Kilborn 1989: 423-424)

As regards economic and time factors, dubbing is regarded as a "much slower, more expensive and complicated technique when compared to subtitling" (Gutierrez 1997: 36).

b) The use of one method or the other will also depend on the levels of investment by the countries where the translation is made. In other words, countries with a small number of viewers usually favor subtitles, while large countries which invest more in this market favor dubbing, as "even though it is the more expensive alternative, it can potentially attract larger numbers of viewers" (De Linde \& Kay 1999: 1).

The question of preference for one or the other method seems to have arisen in France in the early 1930s:

When the issue of film translation was being hotly debated in France, the majority of French artists, intellectuals, and cinephiles strongly voiced their preference for subtitling over dubbing [...]. Subtitling for its elite supporters preserved the foreign character of the source and, therefore, the identity and authenticity of the original. (Danan 1994: 763)

At that time subtitling was considered an elite method because of its preservation of the original source intact. Not many people spoke 
foreign languages at the beginning of the $20^{\text {th }}$ century, and the few who did were usually educated people who belonged to the upper classes. These people favored subtitled versions, which led to the idea that subtitled films were for the elite classes of society. This idea has been confirmed in our days, as most artists and cinephiles still regard subtitling as showing "respect for the original work". On the other hand, many people consider dubbing as "cuestionable, censurable, desterrable... y puede que no estén faltos de razón, ya que no hay duda de la alteración que produce sobre la obra original" (Ávila 1997: 17)

c) In addition, the choice of dubbing over subtitling could be explained in terms of audience demand:

[...] The feeling that "they do not translate what is being said" can be considered as one of the reasons why the public in some countries is loath to accept subtitling and prefers dubbing. (Howard 1994: 581)

In fact, there are spectators who reject subtitles for not always reflecting what is happening on the screen. Others apply this to the dubbing method as well. There are spectators for whom going to see a subtitled film is not as relaxing as watching a dubbed film. The choice of one method over the other is obviously a question of personal preference. As regards the position of the audience, the spectator of a dubbed version remains passive, while the spectator of a subtitled version is active, since he is being supplied with three different channels of information: the images, the original soundtrack, and the subtitled translation: 
Subtitling is particularly informative [...]. Although the information is somewhat redundant, it is of interest to ask whether the three sources of information can be processed simultaneously and if so, to what extent can they be processed and what implications these sources of information have for the viewer. (D’Ydewalle \& Van de Poel 1999: 228)

In many countries (France, Germany, Italy and Spain among others) dubbing is the most common method used for the foreign productions. As a consequence of this:

[...] La Comisión de Política Audiovisual de la Unión Europea declaró, en 1992, al doblaje como sector prioritario alegando que debe existir como una realidad en la que se contemple el rico mosaico de lenguas que posee nuestro continente, pese a ser conscientes del peligro que entraña abrir las puertas al potencial de producción audiovisual norteamericano. (Ávila 1997: 17)

d) Whereas the quality and success of the dubbed version cannot be checked by the viewer, as the original version is not provided, the subtitled version always can be:

A basic difference between subtitling and dubbing is that while the recipient who is familiar with the source language can check the quality of the subtitling - what is known as 'the gossiping effect' in the professional jargon - (s)he has normally no such possibility with regard to dubbing. (Törnqvist 1995: 49)

[...] The cohabitation of source and target texts allows the viewers to immediately compare both messages, which consumers of other types of 
translations (e.g. dubbing or literary translation) cannot normally do. (Díaz Cintas \& Remael 2007: 55)

However, subtitles may also be directly responsible for criticism, as the non-appearance in the subtitles of recognizable lexical items audible in the soundtrack may be perceived by some viewers, who may think that the translator has forgotten to translate the words they have clearly heard on the soundtrack (Díaz Cintas \& Remael 2007: 56). To that respect, Karamitroglou (1998: 6) affirms that:

Investigations in the psychology of viewing indicate that when such linguistic items are recognized by the viewers, the exact, literal, translationally equivalent items are expected to appear in the subtitles as well. This occurs because of the constant presence of an inherently operating checking mechanism in the brain of the viewers which raises the suspicions that the translation of the original text is not 'properly' or 'correctly' rendered in the subtitles, every time word-for-word translations for such items are not spotted.

On the other hand, in subtitled versions the soundtrack of the original is not altered: the TL titles are inserted at the bottom of the screen and these "translate what is being said simultaneously" (Friedman 1974: 43). In contrast to the phonetic synchrony in dubbing, subtitling "is mainly conditioned by the synchrony of time and the spatial and content synchrony" (Gutiérrez 1997: 36).

However, scholars have lately argued that choosing one or the other method of audiovisual translation is more complicated than it seems, as ideological factors play a decisive role: 
Las decisiones de política lingüística serían esenciales para entender casos como el doblaje en las cadenas autonómicas de televisión en áreas geográficas con una lengua regional propia como ETB o TV3, o bien el doblaje de productos cinematográficos procedentes de Francia en Montreal al francés de Québec, [...] y la utilización del doblaje, en un momento histórico determinado [...] en Alemania, en Italia y en España [...], con el fin primordial de eliminar o diluir en la medida de lo posible los elementos que se consideraban inaceptables por parte del sistema político y "nacionalizar" [...] en la medida de lo posible, los productos cinematográficos que llegaban del extranjero. (Bravo 2005: 131)

And as Ivarsson \& Carroll affirm, the choice of one method over the other depends more on what audiences are used to than to rational arguments:

Viewers who regularly watch dubbed films or television programmes tend to find subtitles unaesthetic, irksome and difficult to read. [...] Audiences who are used to subtitles are hardly aware that they are reading them (provided the subtitles are of reasonable quality). Often they do not even notice them. (Ivarsson \& Carroll 1998: 37)

Having briefly discussed these two methods of audiovisual translation, I will now focus on subtitling, since this is the method chosen for the translation of Almodóvar's films in the US film market. 


\subsection{Definition of Subtitling}

Subtitling, once the domain of small countries lacking the funding, interest or infrastructure to dub imported films, has assumed new importance in the late $20^{\text {th }}$ century as communications become more and more global and audiovisual media distribution proliferates. (Ivarsson \& Carroll 1998: 1)

Subtitling is defined as the translation of the spoken ST, and as such this particular form of translation becomes a special type of language transfer. Three simultaneous activities are implied in the process of subtitling:

The transfer of information from one language to another; an abbreviation or condensation of the text; the transfer from the spoken to the written language. (Nedergaard-Larsen 1993: 212)

And the process is in turn influenced by three main factors:

Captions must integrate with the existing material and semiotic structure of a film; speech has to be presented in an altered written mode and subtitles must be designed so as to take account of viewers' reading capacities. (De Linde \& Kay 1999: 26)

The interaction of these three components, together with "the viewer's ability to read both the images and the written text at a particular speed, and the actual size of the screen, determine the basic characteristics of the audiovisual medium” (Díaz Cintas \& Remael 2007: 9). 
The purpose of subtitles is to facilitate the understanding of the film, and to make the viewer enjoy it: "El subtítulo es un auxiliar discreto, intencionadamente discreto, aparece y desaparece rápidamente, dejándonos tiempo para disfrutar de todo lo demás, incluso de reconocer en el original lo que acabamos de leer en la pantalla" (Wuilmart 1994: 505). As for the preservation of the original, "subtitular una película es la única manera de respetar y conservar intactos sus diálogos y su sonido original” (Leboreiro \& Poza 2001: 315). To be successful, subtitles "must appear in synchrony with the image and dialogue, provide a semantically adequate account of the SL dialogue, and remain displayed on screen long enough for the viewers to be able to read them" (Díaz Cintas \& Remael 2007: 9).

The main purpose of subtitling is to convert "continuous or intermittent speech and dialogue into a form in which it can be read" (Kilborn 1989: 427). However, the change from oral to written text entails difficulties for the translator, since spoken/oral and written language have many distinctive features that are not interchangeable:

\footnotetext{
Written language cannot incorporate all of the information conveyed by speech (suprasegmental features) and some typical features of spoken language appear definitely odd and distracting in written form (hesitations, incomplete utterances, interpersonal signals). (Kovacic 1998: 79)
}

To understand what is being said by a specific character requires taking note of the characteristics of the spoken language: rhythm, pace, pauses, intonation, etc. All these characteristics are important in order to understand what is being said, and they can all be replaced in written 
language by printed symbols. But the result will never be the same, just an approximation (Kilborn 1989: 428). For subtitling to be successful:

It must be well executed, however, and this requires special expertise on the part of subtitlers. Subtitlers not only require outstanding language ability and journalistic talent, they must also have good visual sense, a thorough understanding of the film and reading rhythms and a wide range of other skills. (Ivarsson \& Carroll 1998: 1)

\subsection{The Origin of Subtitles}

The origin of subtitles can be traced back to the first half of the $20^{\text {th }}$ century, when only silent films were projected onto the big screen:

During the inaptly named 'silent films' era, audiences could of course not hear the actors' voices. However, that does not mean there were no verbal elements accompanying the images, although they were written and not spoken. (Bravo 2004: 209)

In time silent films got longer and more complicated. Their increased length and complexity were due to the addition of titles as explanatory texts for the changes taking place in the story. As these titles were inserted, the sequence of images was interrupted, and then continued when the title had gone:

Desde el punto de vista del análisis traductológico, el interés para el teórico se suscita cuando el cine comienza a incorporar lenguaje escrito a la representación icónica. Es entonces cuando traducir el texto escrito se torna necesario para la comprensión de la narración. (Chaume 2004: 41) 
The term used then was not 'subtitle', but 'intertitle,' or 'insert title' (Ivarsson 1992: 294), as "it was a replacement shot for a part of a film that contained verbal information in the original language" (Karamitroglou 2000: 6), so that they were used "to convey a few narrative indications or short dialogues (Bravo 2004: 209). These intertitles "are at the origin of subtitles and can be considered their oldest relatives, the first experiments with intertitles having taken place in the early $20^{\text {th }}$ century" (Díaz Cintas 2007: 26). They consisted of short sentences written against a dark background, usually white on black (ibid).

However, these intertitles:

[...] No seguían siempre unos patrones homogéneos. Su diversidad formal (icónica, de caracteres gráficos, de decoración) podía llegar a la confección de frases con faltas de ortografía para sugerir un acento especial o un sociolecto específico. Respecto al contenido, solían consistir en frases sencillas y cortas que aportaban información de tipo espaciotemporal a las imágenes, facilitando así su comprensión y su montaje. (Chaume 2004: 43)

When sound cinema appeared, it largely eliminated their usefulness, and film-makers had to face another problem: the internationality of the film. It was in the 1920s that the translation of films began to be seen as necessity:

En 1927, al comenzar el cine sonoro con Lights of New York, el público francés pedía a gritos que se hablara en su idioma, y el inglés pateaba el acento americano, entonces casi incomprensible en el Reino Unido. (Piastra 1989: 344) 
However, there is another film which is believed to be the beginning of sound cinema:

El primer filme sonoro parece ser El cantor de jazz [The Jazz Singer], estrenado el 6 de octubre de 1927 en Nueva York, con mezcla de intertítulos y algunos diálogos hablados. [...] Durante estos años, por cautela y por no arriesgarse financieramente, las compañías solían producir una versión muda de cada talkie, hasta prácticamente el año 1930. (Chaume 2004: 44)

Therefore, export markets found a simple industry solution: "to shoot new titles in foreign languages and cut them into the film to replace the originals" (Bravo 2004: 209). Because of the growing dissatisfaction of non English-speaking spectators, film studios and companies in Hollywood decided to subtitle the films they exported into three main languages: French, Spanish and German. Later on they expanded into other languages. But one of the limitations that subtitlers had to face was the fact that a great number of people in the 1930s could not read. However, countries like the Netherlands and Sweden immediately accepted subtitling, mainly due to two important facts: the cultural level these countries already had, and the relatively low costs of this modality (Chaume 2004: 47) ${ }^{4}$. As Ivarsson (1992: 16) states, as subtitles are cheaper, countries with minority languages usually favoured this method, while dubbing was the method preferred by those countries which adopt linguistic protection policies characteristic of the resurgence of the National Socialism, have higher investment funds, and in which most part of the viewers would not understand subtitles:

\footnotetext{
${ }^{4}$ Nowadays these countries still favor subtitling and reject dubbed versions.
} 
Éstas son las razones históricas de por qué estos países prefieren los subtítulos al doblaje; cualquier debate entre doblaje y subtitulación debería tener obligatoriamente en cuenta estas variables históricas y sociales, y no establecerse meramente en términos artísticos y criterios subjetivos [...]. (Chaume 2004: 47)

By contrast, in the United States, subtitled versions did not succeed: they were an absolute failure. So film companies introduced dubbed film versions as a solution to the problem:

En octubre de 1929, Radio Pictures dobló la película Rio Rita al español, alemán y francés. MGM, United Artists, Paramount y Fox también empezaron a doblar cortometrajes y largometrajes. (Izard 2001: 197)

In the 1930s "dubbing rapidly established itself as the dominant mode of film translation on an industrial scale" (Bravo 2004: 210):

[...] No fue hasta 1928 cuando dos ingenieros de la Paramount consiguieron grabar un diálogo sincrónico con los labios de los actores de la película The flyer. Este primer doblaje se realizó en alemán, pero enseguida altos cargos de la productora vieron las posibilidades comerciales de este invento que conseguiría romper las barreras idiomáticas del cine y lo internacionalizaría definitivamente. (Ávila 1997: 44)

This method was favored in countries "with very strong nationalistic currents where vehement defense of the national language was common" (Ivarsson \& Carroll 1998: 10). But far from solving the problem, this technique was another failure for the film industry. The dubbing process - sound mixtures and synchronization - was too precarious and defective a technique, and audiences could not accept these versions. Besides, 
some sectors of the industry determined that dubbing "was too expensive, excessively complex (with the technology available at the time), and worst of all too slow to do" (Bravo 2004: 210). Thus it seemed that the appearance of sound cinema, far from being a new and attractive kind of cinema, was creating new problems:

El advenimiento del sonido hizo al público cuestionarse la veracidad del cine, le hizo preguntarse sobre sus posibilidades técnicas, sobre el papel que desempeñaba en el arte y en la vida real. (Izard 2001: 198)

Scholars like Chaume (2004: 45) argue that the bad reputation of dubbing was to be blamed on the bad quality of the voices and the lack of synchronization in the first stages. And as Whitman (1992: 72) also states:

Dubbing was carried out rashly and precipitously. "La mauvaise reputation du doublage tient sans doute à ces débuts qui, on l'imagine sans peine, donnaient des resultants extravagants" [Caillé, Cinéma et Traduction, 104]. Labials were ignored, large openings and closings of mouth signaling mid-sentences silences were overlooked, and syntactic nuclei invariable fell at spots which were at variance with gesticulative emphasis.

After the failure of subtitled and dubbed film versions, Hollywood companies tried another possibility: multilingual versions. These companies would shoot the same film in different languages using different actors - i.e. Spanish actors for the Spanish versions:

Durante unos diez años, hasta 1936, muchos actores españoles estuvieron trabajando en los estudios que la Paramount y otras compañías tenían en varios países, entre ellos EE.UU., Alemania y Francia. (Piastra 1989: 344) 
However, this technique was soon simplified, as "one could let other actors speak the parts translated into the target language and replace the original soundtrack by the new recording" (Ivarsson \& Carroll 1998: 10). Hence, renowned actors such as Buster Keaton, Laurel and Hardy, among others, would shoot the same film in different languages, usually with the help of the so-called idiot cards $^{5}$ :

El resultado son versiones en francés, español o alemán con un acento americano tan marcado que hacía las películas más cómicas todavía. El acento llegó a formar parte de los personajes de tal manera que, años más tarde, cuando ya se habían abandonado las versiones y las películas eran dobladas por dobladores españoles, éstos seguían imitando el acento estadounidense. (Izard 2001: 200)

Again this possibility was criticized and later abandoned, mainly due to the bad criticism they received: "se mantenía (y se mantiene) que los temas, los valores y los lugares comunes varían culturalmente de un lugar a otro y, en ocasiones, al volver a rodar la película, no se adaptaban estos valores a la cultura meta" (Izard 1992, in Chaume 2004: 49). Then, some people started to think of returning to written titles inserted in the lower part of the screen, not between sequences:

That is how subtitles were born, and since it is a relatively low-cost technique - between ten and twenty times cheaper than dubbing (Ivarsson 1992: 16) - it soon became the translation method of choice for language areas with smaller populations such as Portugal and the Scandinavian countries. (Bravo 2004: 210)

\footnotetext{
${ }^{5}$ Izard (2001: 200) describes the idiot cards as "unos cartelones con la pronunciación figurada de los diálogos, que un ayudante sostenía detrás de la cámara para que el actor los leyera mientras actuaba".
} 


\subsection{Types of Subtitling}

It should be emphasized [...] that subtitling is a cover word for a somewhat heterogeneous concept. In reality there are numerous specific types of subtitling. They differ in importance and though they have features in common of course, each of them brings its own problems. (Bravo 2004: 210)

In linguistic terms, there are two types of subtitling: intralingual or closed caption/subtitles and interlingual or open caption/subtitles. While intralingual subtitles are translations within one language, interlingual subtitles are translations between two languages. The former applies to subtitles for the deaf and hard-of-hearing people, and for foreign-language programs directed to language learners, "sometimes to help migrants, for instance, to learn or to improve their command of their new language" (Gambier 2003: 174). In the latter, "the subtitler "crosses over' from interpreting the spoken foreign-language dialogue to presenting written domestic-language translation on the screen" (Gottlieb 1992: 163-164). Interlingual subtitling is often compared to other types of language transfer (translation and interpretation), whereas intralingual subtitling is often related to other forms of transcription (De Linde 1995: 9). As for the latter, Gottlieb (1994) calls it "diagonal subtitling", as it involves a shift from one language to another as well as a change of mode (from oral to written).

From a technical perspective, there are two different types of subtitles: open and closed. The main difference between them is: 
[...] In the first case, the subtitles are burned or projected onto the image and cannot be removed or turned off. The programme and the subtitles cannot be disassociated from each other [...] In the second case, the translation can be added to the programme at the viewer's will. The subtitles are hidden and can only be seen with an appropriate decoder or when the viewer activates them on DVD. (Díaz Cintas \& Remael 2007: 21)

As stated above, this analysis will focus on the films by Almodóvar subtitled in English. Therefore, from now on I will be focusing on interlingual subtitling, also called conventional subtitling (Bravo 2004: 211).

\subsection{Interlingual or Conventional Subtitling}

Subtitling a film, television program, or anything having to do with audiovisual communication from one language (SL) into another (TL) is interlingual subtitling. Subtitling is also a semiotic process: besides implying a change of code (from oral to written) and a change of language, it also brings about other changes such as omissions, deletions and substitutions. In the process of subtitling, there is always something being transformed in order to make the subtitles synchronize with the dialogues that are being heard.

One of the biggest differences between written and oral discourse is that, whereas the former usually displays informative content, the latter includes more personal and interpersonal elements. So the change of code, from oral to written, involves "the disappearance of characteristics of spontaneous speech, such as false starts, incomplete sentences, gradual construction of conversation, corrections, explanations, persuasive 
interpersonal elements, one message broken into two or more parts, etc." (Kovacic 1995: 107). As regards subtitles, this distinction is especially important for "the comprehension of the dramatic or comic development of the story, the relationships between characters, and their psychological states" (ibid).

\subsection{General Features}

According to Reid (1991: 156), subtitling differs from other forms of language transfer in three fundamental characteristics:

1) There is no drastic change in the original work. However, there is a reduction of the field of vision of the image.

2) Subtitling translates spoken texts into written ones.

3) The final product, i.e. the TT, is shorter than the ST.

As far as the production of subtitles is concerned, there is a series of conventions accepted by professionals:

\subsubsection{Length and Time}

One of the main constraints when dealing with subtitles is the limitation of space: only one or two lines can be shown at the same time. This means that the relevant information has to be selected and the rest completely removed, which may be a serious problem for the subtitler. Since the relevant information is condensed, the subtitler has to delete elements that may be superfluous (Guardini 1998: 98).

According to $20^{\text {th }}$ Century Fox, the maximum length of a subtitle is two lines: 
Nosotros vamos a seguir las instrucciones para traductores de la 20th Century Fox Corporation, que establecen un número de 70. Estos setenta espacios se dividen en dos líneas, cada una con un máximo de 35 pulsaciones. En ningún caso para el diálogo se puede superar este límite para un subtítulo, ni siquiera cuando el metraje sea mayor de los 7 pies. (Mayoral 1993: 53)

However, this maximum number of characters per line varies according to alphabets: 35 for Cyrillic languages (i.e. Bulgarian, Macedonian, and Russian), 34 to 36 for Greek and Arabic, 12 to 14 for Japanese and Korean, and 14 to 16 for Chinese; on the other hand, subtitles with less than 4 or 5 characters are very rare (Díaz Cintas \& Remael 2007: 85).

When Bravo (2004: 212) talks about the principal norms in subtitling, he affirms that "it is not necessary to use all the space available for the first line before breaking and going on the second line, nor need the two lines be of equal length".

As for the standard position of subtitles, it is horizontal and at the bottom of the screen "since this limits the obstruction of the image, and this part of the screen is usually of lesser importance to the action" (Díaz Cintas \& Remael 2007: 82).

The work of condensing a subtitle is very challenging, as the audiovisual translator needs to convey the same message in a greatly reduced number of words. Thus the capacity to synthesize a speech in a subtitle is of primary importance. While condensing a text does not entail any special difficulties, condensation to adjust it to a restricting space and to make it coincide with a particular image may sometimes present serious problems. It could be then stated that "quizá la principal y más importante [norma], casi un lema sea 'Lo bueno, si breve, dos veces bueno"” (Castro Roig 2001: 281). 
The time factor is also crucial to film translators; the presentation of the subtitles has to be long enough for an average viewer to read and assimilate the information presented:

Presentation time should be long enough to allow for what is believed to be an adequate understanding by non-professional readers; moreover, presentation time can be arranged so as to match maximally the stretch of speaking time in order to help the viewer in allotting each phrase to the correct personage. (Delabastita 1989: 204)

As it regards norms, each subtitle should remain on the screen about five to six seconds, and the time gap between one subtitle and the next one should be of at least a quarter of a second (Bravo 2004: 212), in order to make it as easy as possible for viewers to read the subtitles. Various factors dictate the presentation of subtitles, and presentation time always varies depending on:

a) The duration of the utterance in the original version; b) the reading speed of the viewers (as the subtitles need to be readable even to slow readers); c) the visual information given on the screen, which also needs to be perceived clearly by the viewer, and d) the editing style adopted in the film. (Guardini 1998: 98)

But the most important rule for subtitles is the need for synchrony with utterances: a subtitle should appear at the precise moment the person starts speaking, and should disappear when the person stops speaking (Díaz Cintas \& Remael 2007: 88-89):

To sum up the time factor in subtitles, it could be said that: 
Subtitles that are kept on screen for a shorter period of time risk appearing and disappearing like a flash and therefore not being read by the viewer. On the other hand, if a very short subtitle remains on the screen too long, the viewers will have time to read it repeatedly, which is equally irritating and can break the reading rhythm. In other words, extremely short subtitles must be used for a good reason and timed carefully. In some cases, a one-word subtitle can just as well be incorporated into the preceding or following one. (Díaz Cintas \& Remael 2007: 85)

Another problem that arises when a long conversation has to be subtitled is that a lack of continuity in the dialogue may create comprehension problems for the audience:

[...] In order to prevent unnecessary confusion on the part of the audience, the translator should write each title so that it is a separate entity which can be read and grasped in a few seconds; it should lead smoothly into the next title also. (Friedman 1974: 45)

On the same line, Bravo (2004: 213) states that "so far as possible, major sentence constituents should not be split. [...] However, if splitting cannot be avoided, suspension points should be used at the end of the title as the sign that the sentence or phrase continues on the next title, which should likewise begin with suspension points".

\subsubsection{Formatting, Expressiveness and Style of}

\section{Subtitles}


An important factor in the external appearance of subtitles is what Titford (1982: 114) refers to as 'formatting'. The main aim of the formatting of subtitles is "to display the syntactic elements of the sentences in the best way, so as to make its reading and assimilation easier" (Gordo 1996: 53). Some of these syntactic elements are:

* When SL and TL significantly differ (for example, Spanish takes longer to transmit information than English does), "cushion words" may be of great help. These words do not add any special meaning, but are necessary in order to achieve success in subtitling

Two lines for the display of a conditional sentence: the first half containing the main clause and the second half the subordinate clause

* Punctuation marks should be avoided when they do not add anything significant

- A full stop indicates that the sentence/utterance is finished

- Accents should be put on capital and lower-case letters

- Words should not be written entirely in capitals in subtitles representing dialogues: capital letters occupy more space and are more difficult to read than small letters. They are used for the translations of signs and other written elements, and should be used in subtitling in the same way as they are used in standard writing

○ Italics are used for voices off (translation of songs, letters, etc.)

- Short dash is used at the beginning of a sentence to denote a change of speaker 
- Abbreviations should be used when possible, that is, when they are widely known by the target audience and may not cause any confusion

- Numbers should be written in figures However, it is recommended not to start a subtitle or new sentence with a figure written in digits

- Parentheses and brackets can be dropped without changing the meaning, as they supply with relevant but supplementary information

- Exclamations and question marks should be maintained as they serve to indicate something that is said loudly or strongly, and may convey different mood

Nevertheless, it should be stated that punctuation conventions are not homogeneous, and "many major subtitling companies maintain their own, unique in-house guides of punctuation rules which they apply as part of their stylebooks and which are sometimes diametrically opposed to the conventions applied by competing companies" (Díaz Cintas \& Remael 2007: 104).

Sometimes the translation of short words is unnecessary, as their meaning is evident in the action taking place on the screen

* Taboo terms: "the policy of translating taboo terms differs according to such factors as the country of distribution (there are strict limitations in the USA for example), and the channel $[\ldots]$, as well as on the producers and distributors involved" (Bravo 2004: 213)

* Perfect synchrony between the subtitles and their corresponding images. Reproducing word by word what a character says is impossible for the translator, in addition to the fact that one cannot read as fast as one hears. But a lack of synchronicity 
between the dialogue and its corresponding subtitle is unsatisfactory. So, in order to maintain the synchronicity of what is happening on the screen, and the dialogue between the characters, with the subtitles, the translator has to adjust the latter: “a) al desarrollo de la acción y del diálogo real (sincronismo); b) a una velocidad de lectura que permita la comprensión cómoda del texto" (Mayoral 1993: 52).

* A big inconvenient of subtitles is the difficulty in expressing “ciertos tonos de la voz, la ironía, el estado de ánimo, la euforia, o recursos retóricos como la parresia, etc." (Castro Roig 2001: 282). In such cases, the translator should try to produce "una traducción que supla en lo possible esa carencia” (ibid)

Every subtitle has to respect the following requirements in order to be successful:

\section{- Condensing the text}

The choice must obviously be made on the basis of what the subtitler considers to be the essential content that should be communicated to the viewers. [...] The subtitler has to interpret the work. [...] Like all interpretations it will depend on the intelligence, knowledge, artistic sensibility and determination of the interpreter, i.e. the subtitler. (Ivarsson \& Carroll 1998: 85)

There are many condensation strategies according to grammar, syntax, and word level (Díaz Cintas \& Remael 2007: 151-161):

1. Condensation and reformulation at word level

a. Simplifying verbal periphrases

b. Using a shorter near-synonym or equivalent expression

c. Using simple rather than compound tenses 
d. Changing word classes

e. Short forms and contractions

2. Condensation and reformulation at clause/sentence level

a. Changing negations or questions into affirmative sentences or assertions, indirect questions into direct questions, etc.

b. Simplifying indicators of modality

c. Turning direct speech into indirect speech

d. Changing the subject of a sentence or phrase

e. Manipulation of theme and rheme

f. Turn long and/or compound sentences into simple sentences

g. Active sentences into passive or vice versa

h. Use of pronouns and other deictics to replace nouns, or noun phrases

i. Merge of two or more phrases/sentences into one

\section{- Omission or paraphrase}

Omission is usually preferred to paraphrase, as it is easier than "compressing the text and less irritating to those who have some understanding of the original. [...] Omission is less intrusive than paraphrase, $[\ldots]$, especially if the original is an artistic work or a statement by a person responsible for the opinions expressed" (Ivarsson \& Carroll 1998: 86)

The elements that can be omitted are mainly:

- Vocatives

- Repetitions of words, phrases or sentences 
- Last names and names (though not at the beginning of the film)

- Adjectives and adverbs in specific cases

- Interiections

- Connectors and discourse markers

- Phatic markers

- Peformative and modal verbs, and verbal periphrasis

- Redundancies with the image (Chaume 2004: 104)

However, not everything is susceptible to be omitted, as viewers "may feel cheated when the aggressive or rude performance of an actor leads them to expect a certain type of vocabulary that is not relayed in the translation, when a laconic exchange becomes a lengthy subtitle, or when an actor who speaks in linguistic waterfalls is given verv brief subtitles" (Díaz Cintas \& Remael 2007: 57).

- Ellipsis

Tautologies and repetitions can be omitted without posing any problem. However, "this does not mean to say that subtitlers should ignore those little words that often make all the difference or give the lie to a person's character" (Ivarsson \& Carroll 1998: 87)

- Merging short dialogues

Remarks uttered by the same person can be merged into a single subtitling, "it is in fact usually much better to represent a series of short questions and answers by statements instead of writing "yes" and "no" constantly" (Ivarsson \& Carroll 1998: 88).

- Simplifuing the syntax and the vocabulary 
The simplification of the syntactic structures will not affect the meaning of the original text.

Subtitlers should take into account that "it is easier for viewers to absorb and it takes them less time to read simple, familiar words than unusual ones" (Ivarsson \& Carroll 1998: 89).

- Subtitle breaks

Decisions on how the subtitles should be divided naturally depend on the timing, but however well this task has been performed, subtitlers should always be prepared to make a few alterations. It may be impossible to achieve complete correspondence between the allotted time and the subtitles, in which case the times might have to be altered and the text adapted to match. (Ivarsson \& Carroll 1998: 90)

- Borrowing time

Any time it is necessary, subtitlers can borrow time from the next sentence, "this means letting the subtitle remain on the screen during the first part of the next sentence" (Ivarsson \& Carroll 1998: 92), but this is done in extreme cases.

- Synchronization

The subtitle must appear on the screen when the speech starts, and disappear when it finishes.

- Transparency

Subtitles have to achieve a certain degree of transparency. If the viewing of the film is not affected by them, the subtitles have been successful.

To sum up, a successful subtitler will also be expected to exert his skill in such matters as "extractar, abreviar y simplificar para mermar lo 
menos posible el sentido del argumento" (Castro Roig 2001: 282). The translator should be aware of those instances in which some parts should be omitted: empty expressions, unnecessary emphatic expressions, exclamation marks, personal pronouns, articles, prepositions, conjunctions, proper and common names that are repeated or understood, references to elements or people that appear on the screen, nicknames, etc. Far from being relevant information for the spectator, these elements distort the understanding and continuity of the story.

As for style, Díaz Cintas \& Remael advocate the necessity of a style guide or equivalent from the broadcasting or subtitling company for subtitlers in which "they can find the main parameters to be applied in their subtitles" (2007: 79). However, this is not very common in real life. Zabalbeascoa was one of the scholars to suggest the necessity of having such documents:

An essential part of the translator's reference material should be a specialized in-house stylebook, which could include all the information that the employer or firm can anticipate that the translator will need to know and use, including glossaries, television policies and translational norms $[\ldots]$ along with a considerable number of practical examples of problems and strategies. (1996: 250)

Regarding these documents, Ivarsson and Carroll (1998: 159) suggest a Code of Good Subtitling Practice addressed to all professionals involved in the process of subtitling, in order to serve as guidelines "aimed at preserving and fostering quality in subtitling" (Díaz Cintas \& Remael 2007: 80). Nevertheless, the Code has its followers and detractors: 
Although many regard this setting of parameters as a commendable effort, for others it is nothing but a dogmatic catalogue of rules and regulations promoting unnecessary uniformity and erasing national idiosyncrasies. (ibid)

\subsection{Subtitling: An Intelligent Solution}

En el mundo académico del entorno de las humanidades, con seguridad como fruto de la mayor preparación cultural, se suele preferir la subtitulación, para degustar la lengua extranjera, la interpretación de los actores originales, del producto original. (Chaume 2004: 54)

Sus cualidades, su superioridad son evidentes, lo que se me ofrece a la vista y al oído, es una obra en toda su integridad, una obra no violada: es un todo al que no le han amputado sus dimensiones culturales e individuales: los personajes son coherentes, el vestuario que llevan corresponde bien a sus gestos, a la cultura que revelan también la voz, la entonación, la famosa cinética. (Wuilmart 1994: 505)

The audience of a subtitled film is very different from the audience of a dubbed one: whereas that of the dubbed version remains passive during the projection, the subtitled film audience tends to be active. A dubbed version is easy for the spectators to follow, unlike a subtitled film, which requires concentration, as well as some degree of literacy on the part of the viewers:

For many viewers, however, such demands are not seen as limitations to subtitling as a method. On the contrary, for them subtitling gives a degree of 
authenticity, in that the original text remains intact beneath the subtitled overlay. From the broadcasters' and producers' point of view there are also clear advantages in the subtitling method, not the least of which are the substantially lower costs and the speed at which the operation can be effected. (Kilborn 1989: 426)

Consequently, dubbing may be thought of as an "easy solution" for the enjoyment of a film, while subtitling can be regarded as an "intelligent solution", as it implies a degree of intelligence on the part of the audience (Reid 1977: 420). As for Leboreiro \& Poza (2001: 315), "subtitular una película es la única manera de respetar y conserver intactos sus diálogos y su sonido original". The increasing popularity of subtitles is linked to "the growing interest many Europeans now have in their neighbors, and their cultures and languages" (O'Connell 1998: 67). In addition:

As Danan (1991: 613) has observed, subtitling "indirectly promotes the use of a foreign language as an everyday function in addition to creating an interest in a foreign culture". In short, subtitling for all its imperfections amounts to an inexpensive, quick, foreign-culture friendly and generally fairly politically correct mode of screen translation. (O’Connell 1998: 67)

Another factor supporting the increasing popularity of subtitles is that they have become a great help for the deaf and hard-of-hearing, as well as for second language acquisition, where they occupy an important position (Törnqvist 1995: 49-51). Besides this:

Interlingual subtitling is bound to have a number of societal and language-political implications. More than anything else, subtitling is instrumental in: 
- Improving reading skills.

- Boosting foreign language skills.

- (Ideally) facilitating easy and cheap international program exchange.

- (In reality) cementing the dominance of English. (Gottlieb 2004: 87)

One of the main advantages of subtitling is the preservation of the original dialogue. In dubbed versions the viewer can only appreciate half of the performance of an actor, and dialogues may be altered because of synchronization. On the other hand, the viewers of subtitled versions "are able to pick up certain tonal inflections and colouring which $[\ldots]$ provide insights into personality, mood or intention" (Guardini 1998: 97). Therefore, one of the positive aspects of subtitles is the possibility of listening in to the original soundtrack of the film: therefore the translator's work must reflect features of the language that are particular to the various characters. In some films the characters' modes of expression are particularly important - drama for example. In such films "the translator should attach importance to those elements that describe the speaker's personality; [...] all features of language, from vocabulary to accent, are fundamental to the construction of a character" (Guardini 1998: 97).

Besides, subtitles have proved to raise literacy levels and to teach the official language of a country to minority language groups:

Recent research in the Netherlands also points to the positive impact of subtitles on the reading proficiency of 5 to 7-year-olds. Subtitling proves to be the main means by which Dutch children learn their early reading skills (Koolstra, 1993, and d'Ydewalle, 1996). Thus it appears that subtitles promote competence in mother tongue as well as foreign language learning. (Ivarsson \& Carroll 1998: 71) 
Scholars like O'Connell (1994: 368) predict a promising future for subtitles due to economic factors:

A subtitled version is, by and large, much cheaper and quicker to produce than a dubbed one. Indeed, it sis said that subtitles can frequently prove to be up to ten times cheaper than dubbing and while many will be surprised to hear that it can take up to one working week $[\ldots]$ to subtitle a none hour television programme, at least only one person need be involved in the process so it is still generally much quicker than dubbing. Consequently, it is likely that the larger, more wealthy countries traditionally considered "dubbing countries" e.g. France, Spain, Germany, Italy, Austria etc will gradually wean their viewers over to more and more subtitled programmes possibly with incentives from the Community.

It seems that the US film market is in favor of preserving the original, as evidenced in its preference for subtitled versions, and for most of the US population watching dubbed films creates some surprise and even laughter in some cases.

\subsection{Constraints}

Besides the advantages of subtitling, there are also disadvantages that are mainly related to space, synchronization, and mistakes:

The disturbing subtitles crowd out the picture and ruin the composition $[\ldots]$. And then they divert the viewer's attention from the picture. The subtitles often flit in and out without being synchronized with the takes, in utter disregard of the film's rhythm and intention. 
The translation does not cover everything that is said. And - worst of all - the ignorant translator has made no end of mistakes [...]. (Ivarsson \& Carroll 1998: 34)

There are three main categories of constraint: technical, textual and linguistic (Guardini 1998: 97):

1. Technical constraints: Time and space of the presentation of the subtitle as imposed by the original work.

2. Textual constraints: The presence of the visual and verbal elements of the original language, the spatial constraints implying the reduction of the original dialogue, and the change in medium (from oral to written).

3. Linguistic constraints: Intra-linguistic, due to the differences in syntax and grammar between the two languages. Extra-linguistic, i.e. "problems referring to the surrounding reality (the cultural context involved)".

\subsubsection{Technical Constraints}

As regards technical constraints, time and space are the main restrictions. Due to the screen size, subtitles need to be accommodated on the screen, taking into account the loss of image and the available reading time. As for time, the presentation of subtitles is dictated by, and depends on, the reading speed of the viewers:

Luyken et al (1991) suggest that average reading speeds hover around 150 to 180 words per minute. This number varies according to the manner in which the text is presented, to the quantity and complexity of the information, and 
to the action on screen at the given moment. Reading speeds are also affected by the readers' interest in the subject. (De Linde 1995: 9-14)

Some audiovisual translators prefer to cut off some subtitles at sentential borders, because they feel that the audience may get lost if the subtitle continues. On the other hand, other translators prefer to continue a sentence into the next subtitle for reasons of continuity (Kovacic 1998: 77). Every subtitle depends entirely on the translator's preferences, experiences, etc. The translator not only translates the text or dialogue from one language into another, but also needs to give it a definite form, since if the subtitles are not successful s/he will be the first one to be blamed.

\subsubsection{Textual Constraints}

In the matter of textual constraints, the visual component of the film is important. In addition to the translation itself, the film subtitler also has to deal with the visual component: "Unlike ordinary translation, the subtitler has the extra constraint of having to fit the new text into the unaltered visual components of the original film" (De Linde 1995: 11). Apart from the change from oral to visual mediums, there is a reduction in the TT; and in addition to these changes, the audiovisual translator has to achieve the synchronization between image and subtitle. Subtitles "have to tackle the impossible task of rendering the informative value of suprasegmental phonetic features, such as intonation in writing" (ibid). The reduction of the text implies a condensation in the dialogue. But this desired condensation is sometimes not achieved, thus bringing about a 
loss of information for the spectator. According to Nedergaard-Larsen (1993: 213), condensation is related to the time factor:

The time factor depends on how fast the audience is expected to read. The greater the reading speed, the less condensation: the subtitles need not stay on the screen for long (allowing time for more subtitles) or more can be expressed in each subtitle (if the two lines are not already filled out).

The condensation of subtitles has to do with two factors: limited time and limited space. Subtitles are to be read while the film runs; at the same time they have to fit on the screen.

There are two types of text reduction: partial and total. Partial reduction "is achieved through condensation and a more concise rendering of the ST" (Díaz Cintas \& Remael 2007: 146). On the other hand, total reduction "is achieved through deletion or omission of lexical items" (ibid). Many times both types of text reduction are combined. Once the subtitler has determined that text reduction is needed, and after assessing how much time and space is available for a translation, the subtitler will proceed to:

- Eliminate what is not relevant for the comprehension of the message and/or

- Reformulate what is relevant in as concise a form as is possible or required. (ibid)

The audiovisual translator has to face the impossibility of adding footnotes, which may help the viewer with the ongoing action. This lack of space for additional information may sometimes end up in omission. 
But the subtitler needs to be aware of when to omit a subtitle in order to provide the viewer with a better understanding. However, omission is not the only solution; abbreviation may be another alternative:

Subtitling should in some cases be abbreviated or toned down in relation to the spoken original, also when factors of time and space do not come into play. (Nedergaard-Larsen 1993: 213)

When translating a film it is important to decide which parts of the original dialogue must be translated completely, which ones only partially, and which should be omitted completely.

As regards the preservation of some elements, Kovacic (1998: 78) points out that ideational elements are usually preserved. If they are omitted, it is due to the semantic structure of the text. The elements frequently omitted are the interpersonal and personal ones, since they usually turn out to be redundant when combined with pictures. Finally, textual elements seem to be less important than ideational ones, both "because coherence of dialogue is supported by continuity of visual material, and because in fictional dialogues the course of a conversation is not really managed by the participants, but by the screen writer and its creator" (ibid).

\subsubsection{Linguistic Constraints}

Sometimes the culture gap between SL and TL is so wide, that to achieve a successful translation the translator has to add information so as to make dialogues or actions more understandable to the audience. Moreover, the translator can sometimes face a more serious problem, as 
when the dialogue is accompanied by some form of additional verbal commentary. In such cases:

The subtitler may well have to resort to the compromise of giving a full rendering of the one strand, whilst giving a much abbreviated version of the other. [...] The decisive factor will always be - as with other forms of translation - whether, without the explanatory addition, the viewer could miss some potentially important element in plot or character development. (Kilborn 1989: 427)

The audiovisual translator sometimes comes across difficulties related to maintaining the expressiveness of the dialogue of the original film. As the text has to be condensed in accordance with subtitling norms, some characteristics of the language such as emphatic language, colloquial expressions, adjectives, adverbs, taboo expressions, jargon, etc. tend to be suppressed, to the detriment of the original dialogue. Many characteristics of oral language cannot easily be represented in subtitles, mainly because of the change from oral to written language:

This presents serious difficulties in representing various aspects of spoken language, such as non-standard dialects and colloquialisms, in written form, and also allowing for the fact that reading comprehension is a longer process for the audience than aural comprehension. (Howard 1994: 582)

Style is also affected in subtitling. There is a need for "cutting", that is, lexical cutting, syntactic simplifications, vagueness in the use of tenses, etc. (Gordo 1996: 54). The same applies to rhythm. In addition, some actors and actresses have special characteristics in their diction that are obviously lost in the written text. 
Audience plays an important role since it is the recipient of the translation. Facing an oral and a written text may cause stress to the audience, as two different systems are presented at the same time. This may be one of the reasons why some people refuse to watch subtitled films: reading and watching at the same time can be stressful and uncomfortable.

Wuilmart (1994: 505) criticizes the negative aspects of subtitling when she states:

Está claro que a los subtítulos se les reprocha a menudo su laconismo, su condición lapidaria. Todos conocemos esa otra experiencia frustrante: ver a un actor mantener durante cinco minutos un discurso, que nos parece interesante o importante, mientras la vista tiene que conformarse con tres o cuatro subtítulos.

When the subtitles of a film are effective, the audience is able to follow the story with minimum effort and to understand it completely. But, the converse effect can also be achieved: "all of us have, at one time or another, left a movie theatre wanting to kill the translator. Our motive: the movie's murder by 'incompetent subtitles"” (Nornes 1999: 17). Yet, it is clear that if subtitlers follow rules, their subtitles will be successful:

Así pues, no acusemos precipitadamente. [...] También existe un “estilo" en los subtítulos, [...] dado que existe un número máximo de espacios que el subtítulo no puede sobrepasar, no todos los matices pueden ser transcritos, [...] la esencia, la sustancia misma, la interpretación verbal y no verbal de un actor son tan indisociables como un dialecto y la tierra que alimenta su fibra más diminuta. (Wuilmart 1994: 506) 
Speech patterns play an important role in the translation of films, and subtitles are supposed to reflect spoken communication. But when the language used by some characters presents a particular pattern, its translation becomes a difficult task since the translator has to adapt subtitles to the speech of each character: formal vs. informal, restricted vs. elaborate. This is done by bearing in mind that subtitles are supposed to maintain the particular 'oral flavor' spoken language contains, and that it is impossible to communicate all the information conveyed in spoken language in written language. A successful subtitle that conveys a particular feature of spoken language will depend on the ability, knowledge and expertise of the translator. One way to compensate for the lack of phonetic and physical cues supporting spoken language in the subtitle would be to produce a more structured syntax of written language (De Linde \& Kay 1999: 26-27).

Some distinctive features of spoken language may appear insignificant to the spectator of a film. But when it comes to its translation, these may be of a great importance. There are scenes in which the neurotic relationships between characters are relevant to the development of the plot. Before these relations develop into conflict, they are represented by conversation cut-offs or interruptions which "are only disruptive and disturb the viewer in following the main thread of a conversation, $[\ldots]$ that is why they are frequently omitted in subtitles" (Kovacic 1998: 81). Thus it depends on the translator's knowledge to judge when to omit ideational content and give way to an interruption. In other words, the translation of subtitles becomes a complex system of relationships in which the fewer the subtitles, the better the understanding of the film. The subtitler must try to express most of the message in the minimum space, knowing when and where not to omit a subtitle, when or where not to express certain elements present in during a conversation - 
hesitations, false starts, surprise, incomplete sentences - and how to do it in the most economical and adequate way.

However, it is important to mention that besides all these constraints, "in countries where the audience can choose between a dubbed version of a film and an original version with subtitles, it is the cineastes par excellence who usually favor the latter" (Ivarsson \& Carroll 1998: 35).

\subsection{The Film, the Film Translator and the Audience}

Audiovisual translation may involve serious difficulties on account of the different channels used in the process. A film can be said to be a "complex art form" (Nedergaard-Larsen 1993: 213) that includes both visual and acoustic channels. Within a film, four different types of film signs can be identified:

4. verbal acoustic signs (dialogue)

5. non-verbal acoustic signs (music, sound effects)

6. verbal visual signs (written signs in the image)

7. non-verbal visual signs (what is otherwise seen in the image)

Subtitles are verbal visual signs that are added to the original image without changing the visuals or the soundtrack of the film. (ibid)

Due to the special features of audiovisual translation, the profile of an audiovisual translator is far different from the profile of other translators:

Para ser un buen traductor de películas, hay que tener en cuenta que la principal diferencia entre éste y los colegas de otras disciplinas es que 
traduce un texto que va a ser interpretado, hablado; un trabajo a medio camino entre la traducción y la interpretación. (Castro Roig 2001: 268)

There are three different professionals involved in the subtitling process:

- The spotter or subtitler: responsible for "the technical task of deciding the in and out times of the subtitles" (Díaz Cintas \& Remael 2007: 34)

- The translator: in charge of the language transfer. A professional that "should have an excellent command of the source and target languages and cultures, and know the intricacies of moving from speech to written texts" (ibid)

- The adaptor: "experts in the media limitations that constrain subtitling and are familiar with condensation and reduction strategies in the target language" (ibid)

However, the general tendency nowadays seems to be the need for a professional who would embody all these three tasks: "a subtitler with the technical know-how to do the timing of the original dialogues, and the cultural and linguistic background to carry out the language transfer, condensing the message if and when necessary" (Díaz Cintas \& Remael 2007: 35).

Facing a translation, the audiovisual translator needs to be aware that the style and expressiveness of the dialogue can be easily lost in the written text. On the other hand, an overly detailed account of this style and expressiveness may result in "overtaxing the audience" (Kilborn 1989: 28). Both extremes are to be avoided. The translator who overlooks the special characteristics of the language spoken in a film cannot achieve a successful translation. Ultimately it is the translator's professional experience that determines the final product. The translator should be aware of the fact that subtitles "run simultaneously to the 
original dialogue, and anyone with a good command of the original language can immediately detect the slightest discrepancy between the subtitles and the original, any omission or error, or presumed error" (Ivarsson \& Carroll 1998: 105). Besides these characteristics, every audiovisual translator:

[...] Debe estar informado de las últimas novedades y ser diligente en la búsqueda de información [...]. Pero, sobre todo, el traductor debe tener un conocimiento exhaustivo de su propio idioma. Un traductor es un lingüista, pero un lingüista principalmente en su propia lengua. Los traductores nunca debemos dejar de estudiar ni de aprender, pues los que trabajamos con el idioma y transmitimos la cultura (con nuestros textos) tenemos la gran responsabilidad de usar el lenguaje como utensilio de trabajo en préstamo. (Castro Roig 2001: 268)

Linguistic varieties, dialects, registers of the language used by the various characters indicate where they come from, and to which social stratus they belong. These particular characteristics of the speech need to be reflected in the TT; if not, the spectator will be deprived of part of the source message. Achieving a perfect, colorful translation of the ST is usually impossible. But the translator does need to find the right way to make the spectator aware of the special characteristics of a character's speech.

Pictorial information in subtitled films also transmits information to the viewer. Indeed a subtitle may not always be necessary, since it may distract the viewer's attention from what is actually happening on the screen. In such cases the best thing to do would be to omit the subtitle. It is the translator's responsibility to know when a subtitle should or should not be omitted. Apart from the condensation of the TT, it is also 
important to include as much information as possible in the subtitle, while avoiding contradictions.

The main objectives to be achieved by any translator are:

4. Que el texto resultante esté expresado de forma natural, es decir, que no parezca una traducción;

5.Que el efecto que produzca en el lector de la lengua término sea el mismo al producido por el texto original en su lector, $y$

6. Que reproduzca toda la información del texto original y refleje, siempre que sea posible, los efectos estilísticos y emotivos. (Castro \& Pereira 1992: 381)

To achieve the quality of natural flow in film translation, the subtitler must take many liberties with the dialogue of a film because the subtitles appear only for seconds. [...] The subtitler's main concern, therefore, is a good dialogue line which conveys to the audience what is being said on the screen. (Friedman 1974: 43)

The translator has to know how to economize on language, and to learn "to translate what is being said in such a way that the viewer can both read it and watch it at the same time" (Howard 1994: 582). These non-linguistic constraints on the translator become evident during the work of subtitling. What the translator needs to be aware of is the cultural gap that can bring about translation problems, so much so, that a certain loss of meaning is inevitable:

Hans-Georg Gadamer [...] sostiene que las diferencias culturales hacen imposible concluir una traducción sin que la originalidad del texto en la lengua origen sufra pérdidas y apunta que: Por muy fieles que intentemos ser, nos encontraremos en situaciones en las que la decisión habrá de ser en cualquier caso inadecuada [...]. (Garrido 1999: 50) 
And as Bravo (2004: 217) has stated, "in any process of analysis and interpretation, everything depends on the intelligence, knowledge, sensitivity, skill and aims of the person doing it".

Obviously each translator, even those working in similar circumstances and conditions, produces their own translation. Translators are first and foremost readers and recipients of the ST. Their reception of the original version depends on various factors: the environment, the culture in which they live, traditions, values, etc. All of these factors determine the work of translation, in addition to individual experiences and influences (Kovacic 1998: 75). In other words, two audiovisual translators given the same script to translate will come up with two different translations. These translations will depend mostly on the professional experience of the translator (the length of time working in the field, the number of films previously translated, the knowledge of the SL and TL). Each translation will somehow reflect personal opinions on different subjects, beliefs, ways of thinking, etc. Sometimes translations of films are not entirely successful: the viewer who knows the SL will sense that a correct and appropriate translation has not been achieved ${ }^{6}$. To sum up, it could be said that:

Subtitlers, perhaps even more than other translators, must have a superb command of the spoken language and knowledge that far exceeds school or even university requirements. They must be familiar with the vast range of idiomatic varieties in use today in every

\footnotetext{
${ }^{6}$ An example might be the American film Primal Fear (Gregory Hoblit 1996), starring Richard Gere (Martin Vail) and Edward Norton (Aaron Stampler). While watching its dubbed version in Spanish - entitled Las dos caras de la verdad -I realized that the lawyer (Martin) was keeping his client (Stampler) from wasting money on an extended legal process. At one point, Martin warns him to save his money "para los días de lluvia" ("for rainy days"). This literal translation of the idiom "rainy days" is incorrect and makes no sense to the Spanish spectator. It reflects the ignorance or negligence of the translator. A correct translation would have been "para los días de vacas flacas".

${ }^{7}$ http://www.bbc.co.uk/dna/h2g2/A220537
} 
conceivable environment, from a university seminar on symbolic logic to the Liverpool junkie cursing his pusher, to the illiterate Sardinian's musing with his sheep. [...] with the erudite and the trivial, the most abstruse sciences and the everyday things that you might only know from having lived in a country for many years. (Ivarsson \& Carroll 1998: 105)

Moreover, the role of the audience is essential in audiovisual translation, and as Bravo (2004: 216) states when referring to Mayoral, “el proceso de traducción no acaba en la producción de la cinta de vídeo con la traducción incorporada, sino con la emisión del producto traducido, y el consumo de la traducción por parte del público y cómo la misma traducción da lugar a diferentes interpretaciones según la idiosincrasia de cada espectador, sus vivencias y experiencias vitales, etc.".

\subsection{Subtitled Films in the US and Europe}

As previously stated, the choice between subtitling and dubbing depends first and foremost on the level of economic investment each country is willing to make. Most of the foreign films that arrive in the US are subtitled once the Motion Picture Association of America (MPAA) ${ }^{7}$ Ratings System has assigned them a rating. The non-existence of a dubbing tradition in the US is directly linked to the fact that the US consumes its own products, and since foreign films are not very plentiful, subtitling is the chosen method for foreign productions (Gilabert, Ledesma \& Trifol 2001: 325)

Apart from the economic factor, the choice between dubbing and subtitling also depends on cultural and ideological reasons (Izard 2001: 
207). In general, the audience of a subtitled film will probably not feel betrayed by the translation in the subtitles since the original source is present. Conversely, the dubbed version of the same film may make the audience feel that they are being deprived of something, since some cultural or social references from the target culture can be heard in the dubbed version: "A movie with subtitles is a very different experience from a movie with a soundtrack only" (ibid).

Even though Europe has more cinema goers than the USA, the fact that Europe is divided into many linguistic regions affects its film industry in a negative way. As it turns out, each country produces films in its own language. So the large number of languages in Europe is one of the main constraints on their popularity in other countries. Not every film produced in France, for instance, can be dubbed or subtitled in order to be commercialized in other European countries. Only some of the films released can be either dubbed or subtitled for foreign audiences. In other words, the European film and TV industry is at a clear disadvantage compared to that of the US: "If the European audio-visual industry is to grow and prosper, it will have to learn to cross linguistic frontiers by using screen translation methods to reach larger audiences" (O'Connell 1998: 65).

At the present time, Western Europe can be divided into two groups: those favoring subtitling, and those favoring dubbing. The subtitling group includes countries such as Belgium, Denmark, Finland, Greece, Portugal and Sweden, while the latter is represented by countries such as France, Germany, Spain and Italy. Besides the economic factor "dubbing can be up to ten times more expensive than subtitling and is therefore not an option for smaller countries" (Gambier \& SuomelaSalmi 1994: 243) -, there are other factors that account for this division:

Sometimes historical or political explanations are offered as well. For example, the development of the European sound film industry in the 
1930s coincided in many countries with a growth in nationalism, and the dubbing of films in particular offered an ideal opportunity to adapt original screenplays to suit the prevailing political philosophy of specific European countries at the time. (O’Connell 1998: 67)

Lots of films were dubbed in Spain during Franco's regime for the purpose of enhancing nationalism:

El doblaje se consolida con la $[\ldots]$ Orden franquista de 23 de abril de 1941 por la que se obligaba al doblaje en español de toda película extranjera. $[$.... El El gobierno de Franco consigue que durante los primeros años de posguerra sea prácticamente imposible escuchar una película en versión original. (Ávila 1997: 45)

In 1937, the Junta Superior de Censura Cinematográfica was created to control all foreign productions arriving in Spain. The following year, 1938, Serrano Suñer published a decree that stated:

\footnotetext{
"Siendo innegable la gran influencia que el cinematógrafo tiene en la difusión del pensamiento y en la educación de las masas, es indispensable que el Estado vigile en todos los órdenes en que haya riesgo de que se desvíe su misión”. (In Piastra 1989: 345)
}

This decree caused serious economic loss for most film productions in Spain, making it impossible to release many of them. In 1939 censorship extended even to scripts and plot summaries. During that time films were only dubbed, and many of them suffered changes and adaptations. Films such as Last Tango in Paris (Bernardo Bertolucci 1972) were prohibited in Spain because of the erotic content; others underwent some changes in 
their content ${ }^{8}$. In these dubbed films, actors did not utter "palabras soeces, no hablaban sobre sexo, no cuestionaban la religión, no criticaban a los dictadores fascistas, etcétera". (Ávila 1997: 25)

\subsection{Familiarity with the SL: An Added Value}

Going to a movie theatre to see a subtitled film always implies a special kind of entertainment for the viewer. Why do we go to the cinema? Usually because we have heard good or bad critiques about a film, or because we are interested in its plot. Perhaps we want to escape from the real world for a while, and forget about our duties and responsibilities. Because we want to dream for a short time before going back to reality, we choose the film we want to see, and depending on the way we feel, we will choose between a dubbed or subtitled version, if available. Some spectators prefer to see a film in their own language. For others, the work of having to read subtitles minimizes the fun of going to the cinema. There are also those people who have no preferences in the matter of film translation.

\footnotetext{
${ }^{8}$ A clear example can be found in Mogambo (John Ford 1953), where Grace Kelly's character (Linda Nordley) tries to interfere with the marriage of Clark Gable (Victor Marswell) and Ava Gadner (Eloise Y.). In the Spanish version, Linda appears as the sister of Victor, so that the members of the censorship board thus opted for incest rather than adultery. In El puente de Waterloo (Waterloo Bridge 1940), Vivien Leigh's role as a prostitute is changed to that of an actress in the dubbed version. In the film Casablanca (Michael Curtiz, 1942), many dialogues referring to the Spanish Republicans, or the Spanish Civil War were omitted and substituted by references to other countries. Other examples of censorship in Spain were the changes in the titles of some films for military or political reasons: Rebelión a bordo (Mutiny on the Bounty) was commercialized as La tragedia del Bounty in its re-release in 1945; Grandes manoeuvres (by René Clair) was Las maniobras del amor in 1956; and in 1962, Judgement at Nuremberg (by Stanley Kramer) was entitled Vencedores o vencidos. Finally censorship in dubbing was abolished in 1978.
} 
Whether or not the viewer has knowledge of the SL, there is "the opportunity to respond to the titles with the private statement, 'I hear more than you are saying"" (Grillo \& Kawin 1981: 26). Who has never seen a film in Chinese, Japanese or any Oriental language, and left the movie theatre with the sensation of having heard more than what appeared in the subtitles? On the one hand, for the viewer who is familiar with the SL, the viewing experience will probably be a "real pleasure", juxtaposing as he does what is read with what is heard:

A pleasant tension is created in seeing the transformation of idioms and untranslatable colloquialism. [...] The knowledgeable viewer of subtitled movies is treated to subtle but delicious little complexities at such junctures, sometimes experiencing a word in several linguistic contexts in addition to its narrative and dramatic context. (ibid)

Undoubtedly subtitles change the experience of a film, adding something to its rhythm and rhetoric, and causing a variety of reactions.

All the different fields of study dealt with in this sectionaudiovisual translation, language, culture and translation, and the translation of humor - come together when we look at the translation of Almodóvar's films for English-speaking audiences. After presenting the 'state of the art', the next step is to analyze the actual translations of his films, focusing on the language, humor and culture that characterize them. 


\section{III}

\section{The Cinema of Pedro Almodóvar}

\section{Pedro Almodóvar: A Spanish Film Director}

Almodóvar, one of the most popular Spanish film directors of our time, was born in Calzada de Calatrava, province of Ciudad Real. Bored by the rural lifestyle, he decided to move to Madrid, where he worked for the national telephone company (Telefónica), and in his spare time wrote and filmed. Franco was still alive, and so nothing Almodóvar did was allowed to be published by the state censor. With Franco's death, dictatorship gave way to democracy, and Almodóvar thus began to release his works.

His first film Pepi, Luci, Bom y otras chicas del montón (Pepi, Luci, Bom and Other Girls on the Heap, 1980) was shot with a Super 8 camera. In 1982 he released Laberinto de pasiones (Labyrinth of Passions), and in the next two years Entre tinieblas (Dark Habits, 1983) and ¿Qué he hecho yo para merecer esto? (What Have I Done to Deserve This?, 1984). Matador (Matador, 1986) and La ley del deseo (Law of Desire, 1987) followed, and in 1988 Mujeres al borde de un ataque de nervios (Women on the Verge of a Nervous Breakdown, 1988) was nominated for an Oscar award. This was the starting point for his career outside Spain, and he was particularly appreciated in the US. Subsequently, he released ;Átame! (Tie me up! Tie me down!, 1990), which surprisingly came under heavy attack from Spanish feminists. To these attacks Almodóvar replied with sarcasm, since he considered that feminists did not really understand what he meant. 
With Tacones Lejanos (High Heels, 1991) he experimented with the genre of the thriller. Kika $(K i k a, 1993)$ is a hilarious comedy about a woman whom all men take advantage of. In 1995, he released La flor de mi secreto (The Flower of My Secret), considered by many critics as a shift in his career. Carne trémula (Live Flesh, 1997) follows a different pattern, as it includes some violence while still focusing on women. Todo sobre mi madre (All About My Mother) won the Oscar for Best Foreign Film in 1999. 2002 was the year of Hable con ella (Talk to Her), released in New York on November $22^{\text {nd }}$ by Sony Picture Classics. La mala educación (Bad Education) was released in 2004, and 2006 was the key year in his career so far with his lastest release, Volver, which has received encouraging critiques everywhere.

Almodóvar has successfully sustained his film career for the last three decades, in contrast to other film directors who have fallen by the wayside. There are film-makers who have had overwhelming initial success in the film industry; however, such immediate success is very difficult to maintain. It is because Almodóvar's career has been so successful since he first started in the 70s that I have decided to choose his works over those of any other Spanish film-makers.

With his first nomination to the Academy Awards in 1989, Almodóvar became popular in the United States. The viewers who saw Mujeres al borde de un ataque de nervios felt encouraged to discover the rest of his works. Besides Mujeres al borde de un ataque de nervios, films such as ;Atame!, Carne trémula, and the Oscar-winning Todo sobre mi madre are extremely popular with the US audience.

Many people in the States have seen one of his films, and the critiques and film reviews are very positive. As far as I know, the most adverse critiques of his work have come from Spain. It is as if his own country, the one that he always portrays, is his most demanding critic. One of the reasons for this harsh treatment is that, while Almodóvar was 
deemed by some critics to be one of the most original and innovative film directors in the 1980s, there are those who dislike specific characteristics of his works:

A pesar de la popularidad de su obra entre ciertos sectores del público español y extranjero, parte del establecimiento crítico español se resiste todavía a aceptar por completo la amoralidad, la anarquía y, sobre todo, la originalidad del director manchego. (Rodríguez 1995: 119)

Almodóvar has won a place in the syllabus of film courses throughout the US (the world's number one film exporter), thus entering the European and Anglo-American canon:

En Estados Unidos, su producción cinematográfica es tanto material de consumo a nivel de masas, por su exotismo y teatralidad, como objeto de estudio en los foros académicos, por ser un nuevo ejemplo de la estética postmoderna que enfatiza las estrategias representativas no miméticas y por ser una filmografía que aparentemente concede poco espacio a la referencialidad histórica. (Martín 1998: 15)

\subsection{Characteristics of his Films}

Almodóvar's films have so many original and innovative characteristics that it would be impossible to explore them all. I would like to review those that film scholars consider especially original and innovative.

Almodóvar exhibits a great admiration for classic films, as reflected in his productions. In every film there is at least one allusion or an image or sequence from these classics. The influence of melodrama in 
his cinema can be seen in the way he uses actual scenes taken from classic Hollywood melodramas. For example:

- In ¿Qué he hecho yo para merecer esto?, two characters go to a movie theatre to see Splendor in the Grass.

- In Matador, the two main protagonists watch the end of Duel in the Sun.

- In Mujeres al borde de un ataque de nervios, Carmen Maura is dubbing a film scene from Johnnv Guitar.

- In :Atame!, Victoria Abril watches Night of the Living Dead.

- In Todo sobre mi madre, Cecilia Roth and her fictional son watch All About Eve, while Tennessee William's A Streetcar Named Desire is present throughout the film.

This presence of the classics is not arbitrary. Every inclusion makes sense in the context, and is relevant to the flow of the narrative. In Todo sobre mi madre, for example, Manuela (Cecilia Roth) is preparing dinner when All About Eve starts on television. Her son, Esteban (Eloy Azorín), makes a comment on the bad translation of the title into Spanish: Eva al desnudo, instead of Todo sobre Eva, as Esteban suggests. Indeed, it is from this classic melodrama that Almodóvar got the title of Todo sobre mi madre.

As already mentioned, there is a clear influence of melodrama in Almodóvar's works with characteristics such as:

- women-dominated narratives

- the perspective of the victim

- moral conflicts

- omniscient narration

- twists and rehearsals

- chance events and encounters

- secrets and dramatic knots that complicate the plot. 
Almodóvar's films have sometimes been compared to those of other melodrama film-makers such as Douglas Sirk, as the productions of both directors have borrowed from what was popular at the time. While Hollywood was producing films with all the characteristics of melodrama, Sirk opted for an especially eccentric and fantastic type of this genre. The world of Sirk and of Almodóvar are full of artifice, in contrast to the naturalism dominant in Hollywood at that time. For the Spanish director, it is the artificial and sumptuous melodrama that is of greatest interest: cinema is nothing but representation. However, in other ways Almodóvar is less close to Sirk: his own films are full of ironv, an element not present in Sirk's work.

All of Almodóvar's films (except for Carne trémula and $\mathbf{L a}$ mala educación) have a female character as protagonist - an obvious emphasis on the female point of view: Marina in iAtame!, Pepa in Mujeres al borde de un ataque de nervios, Manuela in Todo sobre mi madre, etc. All his women are victims in some way or another: Pepa is victimized by her lover who abandons her; Marina is a victim of drugs and of Ricky's insanity; Manuela is victimized by the loss of her only son. Moral conflicts are also present: from a transsexual aspiring actress who commits incest with her father (Tina in La lev del deseo), to a woman who is abandoned by her mother and commits murder (Rebeca in Tacones lejanos). Usually, there is also something hidden in the plots: Manuela keeps a secret from her son in Todo sobre mi madre; the audience finds out at the end of Tacones lejanos who murdered the victim.

The link between Almodóvar's films and the melodramatic genre is in the presentation of a dramatic story accompanied by music at peak moments. Music certainly plays an important role in his work. Almodóvar tends to introduce different types of music in 
his films - from boleros, to pop, or even French or German classics-, and the choice of these songs or pieces is extremely significant, as the performance of a song coincides with an emotional turning point. The lyrics of these songs always have something to do with the plot; sometimes they are a continuation of the dialogue, so that instead of listening to a character's conversation, the viewer is able to follow the action by listening to the lyrics. This is the case with songs such as "Se nos rompió el amor" in Kika, which presents the deteriorated relationship between Ramon's parents as the reason for the "supposed" suicide of the mother. Similarly, the opening song of Mujeres al borde de un ataque de nervios, "Soy infeliz", introduces the feelings of desperation and abandonment of the protagonist. In Todo sobre mi madre, for example, a song entitled "Tajabone" by the $\underline{\text { Senegalese singer Ismaël Lô welcomes Manuela to Barcelona. This }}$ song provides meaning for the development of the action: "Tajabone" is a song for a Muslim celebration about the love of children; so it fits perfectly in a film about motherhood (Allinson 2001: 198), and it "not only gives continuity to an abrupt shift in perspective - from a point of view shot of the train going through a tunnel to an aerial establishing shot of Barcelona - but more importantly introduces a significant African cultural referent that complements Almodóvar's cinematic vision of Barcelona as a global city" (Amago 2007: 14). The inclusion of foreign elements in his films is related to the fact that "Spain has in recent years become one of the world's most irresistible attractants for immmigration (mainly from the Andes, Africa, and Eastern Europe). The profound shift in the country's demographics inside a decade is a topic of endless discourse within Spain but has yet to get play in Almodóvar's corpus" (Goss 2008: 85). On the other hand, Almodóvar sometimes includes songs to create irony as is the case in ;Atame!, a film that 
ends with a song by EI Dúo Dinámico called "Resistiré" which: "not only suggests a happy ending, but points to Marina's submission to, rather than resistance of Ricky's unconventional courtship" (Allinson 2001: 199). Another example of a song used with an ironic sense can be found in his first film Pepi, Luci, Bom y otras chicas del montón, where the audience hears the song "Tu loca juventud" by Maleni Castro. As Allinson points out, it is noteworthy that "when this song first came out in the 1960s, Spain was far from 'crazy', but by 1978-79, the youth of Spain is finally catching up" (ibid). Almodóvar's liking for the Mexican singer Chavela Vargas is evident in his films. In La flor de mi secreto, the protagonist Leo bursts into tears while she watches Chavela Vargas singing on TV the bolero "En el ultimo trago" while drinking. In Kika, the bolero "Luz de luna" by Vargas is sung by a naked Bibiana Fernández. Old songs by different singers are heard in all his films: "Estaba escrito" by Monna Bell - in Pepi, Luci, Bom y otras chicas del montón -, "Salí porque salí" by Cheo Feliciano - in Entre tinieblas -, "Espérame en el cielo" by Mina - in Matador -, "Ay amor" by Bola de nieve - in La flor de mi secreto -; "Puro teatro" by La Lupe - in Mujeres al borde de un ataque de nervios -; "La bien pagá" by Miguel de Molina - in ¿Qué he hecho yo para merecer esto?- etc.

On the other hand, there are songs that are not relevant to the storyline, but simply add comic brushstrokes to the action - two songs by Almodóvar and MacNamara, "Voy a ser mamá" and "Satanasa" in La ley del deseo. Even though some of the songs do not fulfill the narrative content of the action, the lyrics are comical and their omission would only deprive the spectator of the humor that is present in them: 
Song lyrics should be translated whenever they have a bearing on the story or throw light on the content of the film [...]. It may sometimes be appropriate to write these texts in italics, to distinguish them from the rest of the text. [...] Songs that only serve as background music need not be translated. (Ivarsson \& Carroll 1998: 120-121)

In the subtitling process, there are various strategies applied to the translation of songs (Díaz Cintas \& Remael 2007: 127):

- Countries like Portugal use the same font as in the rest of the subtitles, and move the text to the left-hand side of the screen

- Most languages italicize the subtitles of songs and put them in the same place of the screen

- Some companies punctuate subtitles of songs following the conventions of poetry (capital letters at the beginning of each line, and no full stops at the end)

Many songs are the essence of a film; others support the narrative explicitly or implicitly; and others "contribute to the story in a more indirect sense, by suggesting a mood or creating an atmosphere" (Díaz Cintas \& Remael 2007: 208-209). In all these cases, translators should pay special attention to the lyrics.

Feelings are central elements in Almodóvar's films, as they are in all his stories dealing with the love:

Su sensibilidad artística es fundamentalmente sentimental y de ahí que su interés principal se centre en dar expresión a los sentimientos amorosos de los personajes, especialmente los femeninos pero desde la perspectiva melodramática. (Rodríguez 1995: 119) 
And these feelings of love always belong to women, given the presence of female protagonists throughout his films. The relevant position of women in his films has characterized Almodóvar as 'a woman's director', a label that comes from a subgenre belonging to Hollywood classic melodrama:

The Spanish film-maker Pedro Almodóvar has been understood as a 'woman's director', a tag that was used in Hollywood in the mid-twentieth century to connote a particular standard of femaleidentified melodrama. (Maddison 2000: 265)

His productions are distinguished by the presence of a female protagonist, a female point of view, a plot that focuses on the problems of female characters, and on the family:

\begin{abstract}
Almodóvar proclama otro tipo de familia caracterizado por la intensa amistad entre mujeres, la cual llega a adquirir lazos familiares más intensos que los de la familia convencional en el cine. (Corbalán 2006: 146)
\end{abstract}

Passion is another element present in all his films, from beginning to end. Passion for Almodóvar is the centre of life, and life is nothing but passion: this passion is what characterizes the personality all of his characters and their ways of acting - from Manuela, Pepa, Rebeca, to Marina, María, Gloria or Leo. His characters are dominated by passion, and they follow their instincts and desires. All are impulsive, and their wish is to be happy. But this happiness is usually impossible to attain because of men. Interestingly, there is no punishment, no need to repent or repress one's needs. Only impulses and desires count. Society, so influential 
in real life, does not play the same role in Almodóvar's world: society does not get in the way of the characters, as if there were total freedom.

Almodóvar also breaks with the traditional portrayal of family:

La familia para este cineaste no simboliza el espacio privilegiado $y$ primordial que tradicionalmente ha adoptado y adquirido en la cultura española, sino que supone una limitación ante la libertad individual que tanto defiende en su cine. Para él, la estructura familiar convencional se encuentra en proceso de desintegración [...]. (Corbalán 2006: 149)

The family that is shown in his films is characterized by the deep friendship among women, which has sometimes stronger links than traditional families.

The world of Almodóvar's women presents men as the centre of their lives. But as the story develops these women find out that they can live without men, they do not need them to continue with their lives, sometimes even excluding them altogether. A clear example can be seen in Mujeres al borde de un ataque de nervios. At the start of the film, Pepa - the protagonist - is desperately trying to get in touch with her ex-lover, who has just abandoned her. However, as the film develops, she realizes that she can live without him, and when at the end of the film he asks her to give him another chance and be together, she rejects him. In other films, the relations are between women; men are regarded as a disruption to the happiness these women are looking for. In Todo sobre mi madre, the main relationships are those of Manuela with the other women. 
The idea of women as actors is one that has long been a preoccupation of Almodóvar's films, for example, in Women on the Verge of a Nervous Breakdown [...]. In All About My Mother, motherhood is equated with acting, with the production of a performance. Motherhood is not a biological given but a chosen role, fashioned by women's experience. (Maddison 2000: 279)

The director wants the audience to be aware of the fact that what thev are watching is a representation of real life, and that women are simply representing their own roles. In Mujeres al borde de un ataque de nervios, Pepa is a TV actress, who also works at dubbing films; in ¿Atame!, Marina is a pornostar-actress; in Todo sobre mi madre, Manuela is a nurse who also works as an actress in a seminar about organ donations. Like Manuela, the two other protagonists, Huma and Nina, are also actresses plaving $A$ Street Car Named Desire.

Almodóvar's films have been widely criticized for being antihistoricist, since they do not contain anv direct references to Franco or the post-Franco period. However, history is always present in his films:

El sustrato histórico $[$.... $]$ está siempre presente en el cine de Almodóvar: la emigración rural a la ciudad, el hacinamiento urbano, la drogadicción, la imaginería católica, la denuncia del patriarcalismo, la violencia 0 la actitud pasota del postfranquismo. Todos estos fenómenos demuestran un alto grado de documentalismo social. (Colmeiro 1997: 119)

As for Todo sobre mi madre, it is "a film about connections: national, translational, subnational, familial, cultural, social and genealogical" (Amago 2007: 12). It has also been defined as the resolution of Almodóvar's twenty-vear search "for an understanding of the 
nation's identity crisis [that] settles into the suggestion of ambiguity as Spain's strongest sign of current stability" (Acevedo-Muñoz 2004: 37-38).

There is a reason for this lack of direct allusion to Franco and the post-Franco period: according to Almodóvar, the effects of history are extremely real and history is "what causes pain" (Martín 1998: 16). Therefore, he opts for including references to history, but in a fictitious, rhetorical and even theatrical way. A clear example can be seen in La flor de mi secreto. When the protagonist Leo has a breakdown, she goes out and steps into a demonstration of medical students in the streets of Madrid. The purpose of the demonstration is to show their disagreement with the government policy (PSOE). The students sing improvised songs against Felipe González, former president of Spain, whose political party was the centre of both an economic and a social scandal. It is by means of this demonstration of innocent university students that Almodóvar criticizes a central problem of that time. His films clearly show the contrast between the old and the new Spain: the transition from a dictatorship to a democracy - a radical change for the country.

Another characteristic of Almodóvar's works is 'camp'. Camp could be defined as a taste for the unnatural, a taste for artificiality:

El Camp es juguetón, es un lúdico por excelencia, o más bien, establece una relación más compleja con lo serio, frivolizándolo y tomando lo frívolo con seriedad. (Yarza 1994: 7)

This camp is present in women's magazines, songs, etc: 
Como Warhol, Almodóvar se sentirá atraído hacia las manifestaciones Camp por excelencia: revistas para mujeres, canciones sentimentales, en especial los boleros y las rancheras, subgéneros cinematográficos, y en general hacia todo lo frívolo y artificial, huyendo de todo lo supuestamente auténtico y original. (Yarza 1994: 26)

Camp can be seen in the comment La Agrado makes in Todo sobre mi madre about the magazines of the $70 \mathrm{~s}$ in which she finds her inspiration, and which were stolen by Lola. The songs the director includes throughout his films talk about feelings: they are boleros by Chavela Vargas that express desperate anguish.

Another camp strategy he uses is the figure of the transvestite, which in cinema implies a rupture with tradition:

El travesti en la obra de Almodóvar indica una ruptura, genera el conflictivo espacio donde se pone de manifiesto la falta de efectividad de las divisiones tradicionales que configuran la identidad sexual. (Yarza 1999a: 193)

By means of the transvestite and the transsexual he represents masculinity concealed under feminine clothes:

\begin{abstract}
Almodóvar también utilize de forma similar en su cine la figura del transsexual para problematizar y desestabilizar otro concepto que ha sido naturalizado y normalizado: el de la familia tradicional. (Corbalán 2006: 154)
\end{abstract}

With camp elements, Almodóvar tries to make the audience identify with the action and the characters and, at the same time, to present a different reality that the character does not share. The director does not use camp for mere aesthetic reasons; rather, camp 
in his films helps him stray from aesthetical Puritanism and away from what is socially dominant:

Éste es, precisamente, el legado de la sensibilidad camp: el acercamiento a la realidad en términos de artificio y simulación, la apreciación de las superficies y texturas, lo frívolo y lo melodramático, el énfasis en la apariencia y no en la esencia; o más precisamente, la convicción de que apariencia/esencia, simulación/realidad, frivolidad/seriedad, artificialidad/naturalidad son dicotomías completamente obsoletas. (Yarza 1999b: 72)

\subsection{Pedro Almodóvar: A Postmodern Film-Maker}

Indeed, Almodóvar has been labeled a "postmodern" film director because of the original characteristics of his works: the influence of classic films and melodrama, the dominant presence of female characters, music, the presence of feelings and passion, the female point of view regarding men, the significance of representation, the accusation of antihistoricism, and camp.

In this way the director broke with the previous tradition and set himself free to express and do whatever he wanted to, breaking out of all the restrictions Spain had known for so long. Thus he was free to experiment with his dream of presenting the viewer with a different kind of film. 
His audience is able to witness a mixture of elements, and a breaking away from previous tradition. His postmodernity consists in mixing aspects of mass culture with artistic features (Allinson 2001: 209). The viewer is witness to a set of different and special characters, such as we see in Todo sobre mi madre, Manuela, a nurse, is friend to a transsexual ex-truck driver who just retired from working as a prostitute, and they both become friends of a nun who is carrying the baby of another transsexual infected with AIDS. This variety of characters can only be found in Almodóvar. Who could relate a pregnant nun, a nurse and a transsexual ex-prostitute in such a refreshing and off-beat way?

Deme algo de color, no quiero vestidos oscuros, me he pasado la vida vistiendo de negro. Desde los tres años, que se murió mi padre, hasta que estuve embarazada de éste- me señalaba a mí- encadené un luto con otro. ${ }^{3}$

Almodóvar's use of color is also representative of postmodernity. He has always stated his rejection of black, as his childhood was influenced by his mother in perpetual mourning. He tries to avoid black and dark colors, presenting a colorful world: his heroines always wear bright colors, the rooms of the houses have outlandishly colorful walls, furniture, and pictures. All these colors are carriers of meanings: they depict the feelings of the characters, the social classes they belong to, the time in which the story takes place (Colmeiro 1997: 116).

Almodóvar continually emphasizes "acting" as stated above. All his protagonists at some point refer to the idea of life as a representation, life being nothing but acting, and people mere actors (Allinson 2001). Representation for him is always present in real life, and at one point or

\footnotetext{
${ }^{3}$ Words of Almodóvar's mother in Comeiro (1997)
} 
another, people have to represent a particular role in order to keep from going insane. At the beginning of Todo sobre mi madre, the viewer sees Manuela performing the role of the wife of a man who has just died, and whose organs are being donated. Later on Huma asks her if she knows how to act, and Manuela answers that she can lie very well and is used to improvising. Almodóvar's characters are constantly pretending to be what they are not. A clear example can be seen in Mujeres, when Pepa pretends to be someone else when she visits Paulina Morales, the lawyer who is her boyfriend's lover. In Tacones lejanos Femme Letal pretends she is a drag, when in fact, she/he is Judge Domínguez. Everyone is in disguise; the characters are continually taking on roles (such as Manuela in Todo sobre mi madre when she starts working as a personal secretary for Huma and Nina) or false identities (such as Judge Domínguez in Tacones Lejanos when he transforms himself into Femme Letal, a drag queen): "Almodóvar, de este modo, se gana su etiqueta de "moderno" gracias a las múltiples lecturas que encierra su cine" (Martín 1998: 15).

Some scholars forget the element of modernism in Almodóvar's work:

Lo novedoso y lo "moderno" del cine de Almodóvar reside no tanto en el empleo de elementos "menores" y marginales, sino en demostrar que la dicotomía mayor/menor (alta cultura/cultura de masas) se fundamenta en una división falsa e ideológica. (Martín 1998: 16)

Indeed, the dichotomy of good/bad disappears, in such a way that his world does not represent it anymore, and his characters are atypical, according to the guidelines of the postmodern thought (Rodríguez 1995: 125). Whereas in films by other film-makers, low and high cultures do no mix, they mix perfectly in Almodóvar's work. Characters from a 
particular social class are friends with others belonging to an opposite class: in Todo sobre mi madre, Manuela, an upper-middle class nurse who leads a respectable life, has a close friendship with La Agrado, a transsexual ex-prostitute. She mixes perfectly well with the lower classes of society, even with its most rejected members.

Whereas postmodern film-makers opted for the exclusion of all references to the past, and to history, in Almodóvar's films the spectator does not perceive any allusions to Spain's recent past. Instead, Almodóvar chooses to present the New Spain, the Spain that has seen the decay of fascism, and even the decay of socialism (Allinson 2001). Almodóvar leaves aside any direct reference to the Franco era, since he sees no point in representing the terrible Spain that is finally over and done with. He finds it more appealing to present the new Spain as a country of freedom.

Thus it can be said that Almodóvar's broad knowledge of the classics has encouraged him to create a different kind of melodrama that includes his own special features. Female characters pervade his films: the audience is immersed in a female point of view, and empathizes with their suffering. It is a world without men. This revolutionary idea of women trying to live without men and succeeding is very Almodovarian. Even though he downplays classic Hollywood melodrama, he also follows some of its characteristics: the use of music at peak moments and the emotional struggle of the characters. Focusing on the idea that representation is present everyday, everywhere, he presents his characters as actors. Although clearly influenced by classic Hollywood melodrama, he does not follow traditional conventions. He creates his own convention in which the idea of representation is essential to the story line of every film. Although he has been falsely accused of anti-historicism, these 
accusations do not hold water, for Almodóvar does represent history, but in his own subtle way.

\section{The Reception of Almodóvar's Films in the United} States

\subsection{Reception Theory and Reception Studies}

The world of cinema is a complex one in which diverse aspects converge. The act of creating a motion picture consists of numerous steps: creating a picture, its filming, the ensuing production, and its release are just the beginning of a long process in which the audience plays an important and relevant role. According to many schools of literary criticism, the role of the reader is as important as the function of the text itself: "no concluye el acto creador en la concepción y textualidad de la obra, sino que continúa en el proceder de la recepción y de su historia efectual" (Prado 1991: 26). The way in which the reader receives the literary work is essential to this piece of art.

Literature, as well as cinema, produces unique reactions and effects in each individual who acts as receptor, which reinforces the importance of the reader in literature, since s/he "cobra, así, la misma importancia que el autor y el texto, de igual manera a lo que ocurre con los contextos desde los cuales la obra es emitida y recibida para ser continuada" (Prado 1991: 27). As this also applies to cinema productions where the spectator is on the same level as the director and the film itself, and the former's response is of great relevance to the future outcome of the picture. The importance of reception in the world of cinema is unquestionable. 
Despite the importance of the reception in literature and cinema, up until the 1980s reception theory was unknown in the United States. Until that time, some works on audience-response or reader-response criticism were relatively well-known, especially those by Wolfgang Iser $^{4}$. This decade was to witness a change in reception theory with the publication of books by Hans Robert Hauss, journals of criticism such as New Literary History and Diacritics, as well as works on audienceresponse or reader-response criticism.

Reception theory was born in German literature departments, and its subsequent acceptance in the United States was not easy. Its appearance in the US produced profound criticism that confirmed the optional and marginal character of reception theory as a theoretical tendency. The reasons for this lack of interest regarding a branch of criticism which had been so popular in both Germanies might have been due to the "lack of philosophical grounding for a reception of reception theory" (Holub 1989: 213). In addition to this, it was also stated that such a notable lack of interest could have been due to "its image and 'marketing' vis-à-vis theories which have proved more popular and adaptable for US scholars" (ibid). The lack of philosophical grounding in such theory led to the preference for other theories over reception theory.

This "marginalized" theory of reception also received the labels of reader-response criticism and reception aesthetics. We will focus on Staiger's acknowledgement of the term "Reception Studies", as we believe it is more adequate for our purpose of analyzing the reception of Almodóvar's films in the US. Staiger uses this term both to link these studies, and to separate it from previous works, and she denies any

\footnotetext{
4 Iser established a distinction between aesthetics theory of reception (Rezeptionstheorie) and aesthetics reaction theory (Wirkungstheorie), the latter being his main focus (El proceso de la lectura: Un enfoque fenomenológico,1985. Introduction by Juan Vargas Duarte)
} 
philosophical dimension to these studies, since for her the objective of reception studies is to research "the history of the interactions between real readers and texts, actual spectators and films"(1992: 8). Indeed, it is history that dominates reception studies, which deals with "what has actually occurred in the material world" (ibid): what already happened can be historically proved, and what did not happen can only be the object of speculation. Reception Studies simply seeks to explain how individuals have understood texts, and its main direction is to understand the relations between readers/viewers and texts/films. The special characteristic of Reception Studies is not textual interpretation:

Instead, it seeks to understand textual interpretations as they are produced historically. As Jonathan Culler characterizes research in reception, it "is not a way of interpreting works but an attempt to understand their changing intelligibility by identifying the codes and interpretative assumptions that give them meaning for different audiences at different periods". (Staiger 1992: 9)

\section{Whereas textual studies focus on clarifying an object - i.e. a film -, reception studies seeks to "explain an event (the interpretation of a}

\section{film)" (ibid).}

The reader of a text, or the spectator of a movie, is the starting point of reception studies, and occupies a prominent and central position. For Staiger, it is wrong to consider reception studies as "an antithesis to a hermeneutics based on the authority of production (authorship)", and the idea that "reception studies eliminates the need to examine production since [...] meaning is produced by the reader" (1992: 3) is totally rejected. Reception studies focuses on the reader - or in the spectator in the case of films -, but does not play down the role of the author. 
One studies how audiences receive films not just to predict their success or failure. Studies in the reception of motion pictures are necessary in order to act wisely in political situations for example, or to change the production and consumption of cultural products. In short, Reception Studies has a significant importance for society.

Staiger criticizes previous studies on film audiences and on the reception of movies, since according to her, these works have "relied on inferring effects from textual analysis or social behaviour" (1992: 12). According to her, the authors of these studies have each produced their "own hermeneutics of the text", and have drawn their own conclusions from these observations. As regards examining audiences, historians tend to generalize concluding that every audience behaves consistently with "the same measure of rigor". They thus assume homogeneity among spectators, implying a continuous idealization of the audience, finally labeling their subjects as "free readers".

\subsubsection{Modes of Reception}

Reception is not only important for the study of films, but also as a basis for sociological, cultural and aesthetic theories. Although there has been a lot of speculation regarding the experience of going to the cinema, we still need to focus on: "What is the experience of cinemaviewing for the audiences?". Previous speculations have not been irrelevant; and it has opened up the research on reception.

In "Modes of Reception" (1999), Staiger presents three different speculative histories of reception by three different authors: Tom 
Gunning, Miriam Hansen, and Timothy Corrigan. These authors have provided theories on the entire history of US cinema.

Gunning divides US cinema into two types, cinema of attractions and narrative cinema:

-Cinema of attractions

It emphasizes the presentation of "a series of disjointed and sometimes specular views".

The result of this cinema entails a "critical involvement of the spectator".

This cinema is equated with the "popular" mode of reception.

-Narrative cinema

It emphasizes "story-telling".

The experience is "an absorption into an illusion".

It is equated with a "bourgeoise" mode of reception. (Staiger 1999: 307)

On the other hand, Hansen shows herself to be more skeptical about the "ideological empowerment of early modern cinema" (ibid), as for her, early modern cinema creates the ideal public because of the active engagement of its audience. She also asserts that early modern cinema enabled female audiences "not only to become participants in the public but also to be socialized into a consumer culture" (Staiger 1999:308). She also offers corroboration that early modern cinema existed until the era of synchronized sound.

Corrigan sees a tripartite division of U.S. film history into:

-"Pre-classical cinema” (1895 to circa 1917)

-"Classical and modernist cinema" (1917 to present and 1950

to present respectively)

-"Postmodern cinema" (1970s to present) 
This division is related to the opposition he makes between the cinema of "glance" and of "gaze": pre-classical and postmodern cinema do not involve paying continuous attention to the screen ("glance"), whereas classical and modernist cinema do ("gaze"). As for the spectator, the gaze cinema is a cinema of interpretation and reading, while the glance cinema is one of performance. Corrigan's history is as follows:

Pre-classical cinema "disappears" with the emergence of classical cinema, rather than viewing some practices as dominating others as Gunning argues. Like Gunning, Corrigan argues that some recent films display a re-emergence of audience effects similar to those of the preclassical era, a thesis Hansen has recently adopted. (Staiger 1999: 309)

To sum up: the three writers highlight different modes of address that shift in the course of time, and they also accentuate modifications in presentation. They all agree that "permutations in how the film addresses the audiences or how the audiences experience the films create different cinemas at sequential historical moments" (ibid). Such a diversity of cinemas is due to these permutations of the ways motion pictures address audiences, and how these audiences experience them.

André Bazin - in his essay "The Evolution of the Language of Cinema" - presented a new argument concerning the history of cinema: dividing the history of cinema according to the appearance of synchronized sound was a mistake. According to him, the history of cinema should be classified according to those directors "who have faith in the image versus those who have faith in reality" (Staiger 1999: 315).

Observing the history of films, one sees that there is also a history of different modes of address. By accepting the claims of the previous 
theorists, Staiger (1999: 316) tries to include the different film genres in both types of cinema modes stated above - glance and gaze -:

-Gaze genres: detective, romance, melodrama, thriller, gangster, comedies of re-marriage, some horror films and musicals.

-Glance genres: action-adventure, many comedies, fantasies, specular science-fiction, westerns, slapstick or gag comedies, some horror films and musicals.

These different modes of address that influence reception are also linked to the modes of exhibition (the construction of drive-ins as glance environments, for example).

The approach Staiger offers of the two modes of reception is a historic-materialistic one, considering the cognitive as well as affective activities of the spectators in relation to the event of interpretation, and it presents different modes of address and presentation. History is of great importance in her approach due to the fact that historical circumstances “create 'interpretative communities' or cultural groups such as fans who produce their own conventionalized modes of reception" (1999: 318)

\subsubsection{Dominance of Film and Video Industry by the United States}

One of the reasons why I chose Almodóvar's films, over any other director's works, as the corpus of this study was the increasing success of his works in the US film market. It is a market that has 
become powerful not only numerically in terms of the annual releases Hollywood produces - India also releases hundreds of motion pictures each year and it does not exert the same control -, but also because of its dominance in the world of film and video entertainment as a product of global distribution and consumption.

The dominance of the United States in the film and video industry has been achieved by:

A vibrant and thriving industry built in part on an American love of technology, a need to socialise its immigrant population and the fervent belief that the American political system represented the most advanced form of democracy and therefore should be exported to other countries. (Lorimer 1994: 65)

This industry would not be what it is without the role played by movie stars who have impressed audiences and attracted them to movie theatres. For some spectators, going to the movies means a temporary evasion from the real world, and the possibility of identifying with one's favorite movie stars for an hour or two. Throughout the history of cinema, this adoration for movie stars has even created a massive desire in people to become what they have seen on the screen. This enormous participation has at times been too much for the industry to assimilate. Nevertheless the great demands made on the industry have spurred the development of "an educational infrastructure that ensured a continual flow of acting, technical and managerial talent into the industry" (Lorimer 1994: 99). And this has been a very positive aspect derived from the US supremacy in this field. Besides the educational infrastructure, other positive achievements have been attained by this industry, for example: "domestic employment, derivative industries, a 
high level of export sales, the articulation of American values for domestic consumption, and advancing U.S. ideology abroad" (ibid). One can see reflected in such statements, the type of patriotism characteristic of most of the US population, and concomitant desire to export their lifestyle and ideology. In fact, the US film and video industry is deeply linked to politics:

The head of the American Motion Picture Association is apparently able to command the support of the President, the Secretary of State, the Secretary of Commerce and the United States Trade Representative on the matter of possible restriction of export opportunities of US movie and video products (Canadian Communication Reports, 31 December 1989, pp.2-3). (Lorimer 1994: 99)

Not surprisingly, the supremacy and dominance of this industry is not free from constraints concerning the release of particular motion pictures.

\subsubsection{Censorship in the United States}

Censorship is a form of manipulative rewriting of discourses by one agent or structure over another agent or structure, aiming at filtering the stream of information from one source to another. [...] Censorship is [...] an act, often coercive and forceful, that - in various ways and under different guises blocks, manipulates, and controls the establishment of cross-cultural communication. (Billiani 2007: 3) 
Censorship has never been relaxed in the production of US films and videos. In his article, "Changing Perceptions of the Movies: American Catholics Debate Film Censorship" (2001), and in his previous book Hollywood Censored: Morality Codes, Catholics, and the Movies (1994), Gregory D. Black presents an interesting summary of US censorship since the 1930s.

Black analyzes the world of censorship of the 1930s in Hollywood, when in 1930, a movie code was written by a Catholic priest, Father Daniel Lord, as for him movies were corrupting American values:

Lord's code, which soon became the Bible of film production, banned nudity, excessive violence, white slavery, illegal drugs, miscegenation, lustful kissing, suggestive postures, and profanity from the screen. [...] His code also held that films should promote the institutions of marriage and home, defend the fairness of government, and present religious institutions with reverence. (Black 1994: 1)

Lord, together with other Catholics, gathered for several months as to produce a more severe code of behavior, and they believed that "the only way to make morally and politically acceptable films was to exert influence during their production and thus - if films were made correctly - they would need no censorship" (Black 1994: 39).

As a reaction to Lord's code, Will Hays, president of the Motion Picture Producers and Distributors of America (MPPDA), agreed and sponsored the code without any question, and it was adopted in 1930 by the motion picture industry. However, the Catholic Church and other religious organizations expressed their dissatisfaction with the way the 
industry enforced the code (Black 1994: 2), and in 1934 they created the Legion of Decency (LOD), whose function was to classify movies for Catholic audiences and prohibit the screening of those motion pictures catalogued as immoral. However, the real aim of both the translator and the censor in the manipulation of texts was not to ban them from public performance, "but rather to make them somehow acceptable and ready for public dissemination” (Billiani 2007: 10).

The Legion had to review all films released and then rate them by their content ${ }^{12}$ : "The LOD stood ready to condemn any film considered immoral or dangerous. Catholics were forbidden to attend any film condemned by the church (Black 1994: 2). When scenes or dialogues were offensive or unacceptable for Catholic audiences, the producers were forced to suppress them if they wanted their works released. The Legion even threatened to condemn works such as Duel in the Sun (produced by David O. Selznick), or The Outlaw (Howard Hughes). Under the threat of heavy fines, the producers were at the mercy of the Legion.

Normally producers tried to defy the Legion by releasing prohibited works, but they usually had to withdraw them in the end because of low box offices sales. Nevertheless, the Legion always came across producers and even directors who did not accept their decision. For example, Howard Hughes, producer of The Outlaw, dared to release his film despite the Legion's rating in order to find out how it would do in the box offices: strikingly, it was a box-office hit everywhere. If this could happen to one film, it could happen to others. But when producer

\footnotetext{
12 The rating system followed by the Legion of Decency was as follows:

A-I. Unobjectionable for general audiences

A-II. Unobjectionable for adults

B-Objectionable in part for all

C- Condemned (Black 2001: 79)
} 
Preminger tried to do the same thing with The Moon is Blue, that movie did not achieve the success of The Outlaw.

In the summer of 1956 an article by a "prominent Catholic theologian", John Courtney Murray, questioned the authority of the Catholic Church to engage in censorship with the help of the Legion. According to Murray, no minority group had the right to use the pretext of belonging to a religious group in order to ban Catholic audiences from going to see a film. In the late 1950 s the Catholic Church reacted by holding two debates regarding censorship:

One focused on whether, and by what right, Catholics should be forbidden from attending certain films. The second, more revealing perhaps in terms of attitudes to films themselves, exposed an increasingly complex range of opinions among clerical and lay Catholics over the reception of a number of films that themselves expanded the boundaries of what was permissible in film entertainment. (Black 2001: 81)

In 1956 Murray published another article, "Literature and Censorship", in which he criticized the condition of film censorship at that moment, stating that censorship entailed a lack of freedom of expression in a democracy; nevertheless, he did agree to censorship as far as pornography was concerned. For Murray, censorship was being applied according to the moral criteria of the censor, and it deprived men and women of judging for themselves. His article was published with ecclesiastical approval, which possibly reflected a gradual internal change in the attitude of the Catholic Church.

During the decade of 1940s and 1950s, motion pictures which had been labeled as quite controversial by the Legion "did exceedingly well 
in urban areas with large Catholic populations" (Black 2001: 82). This discovery corroborated the theories contained in the article "Theological Studies" published by Father John C. Ford, a professor of moral theology, who stated that Catholics were paying little attention to the Legion's opinions.

In 1957 there was a New Papal Encyclical, Miranda Prorsus, by Pope Pius XII, in which he celebrated cinema as one of the most important inventions of mankind. It thus encouraged Catholics to include and to pursue cinema studies in Catholic schools and universities. This Encyclical broke with the previous one, Vigilanti Cura, by Pope Pius XI, which literally banned improper movies. In other words, Pius XII's Encyclical meant a position that was in opposition to what the Legion was doing. The Catholic Church had decided to change direction by opting for an internal modernization ${ }^{13}$.

When the Legion of Decency was created in 1936, a division was also approved who would review the Legion's staff: the International Federation of Catholic Alumnae (IFCA). The Motion Picture Exhibitor severely criticized this group for being unskilled and untrained. They were accused of not being able to separate their personal preferences from their responsibilities, and of continually disagreeing with each other about some films.

The Legion continued to express its objection to scenes and dialogues in some pictures, and Elia Kazan's Splendor in the Grass was one of those thus criticized, and the debate on the objectionable morality of some scenes lasted for a long time. Kazan of course refused to make any cuts, since he possessed the final authority, and while some Legion

\footnotetext{
${ }^{13}$ Due to this Encyclical, bishops accepted a new rating system: A-II. This films could be seen 'by the young' A-III. This films could be seen 'by adults' (Black 2001)
} 
consultors did not see anything immoral in its scenes, others expressed their totally different opinions. There were also consultors who definitely condemned the film for its promotion of "free love". Finally, Kazan, following the advice of Jack Vizzard - a PCA's (Production Code Administration) expert -, decided to change the scenes and dialogues which had been condemned as offensive. Despite all the obligatory cuts, the Legion issued the film with a B rating.

The Legion's tendency to condemn more and more pictures gradually led to a rebellion among Catholics, most of whom decided to ignore its warnings regarding films. This is evidenced in the spectacular box office success of censored pictures such as The Sign.

However, Fellini's La Dolce Vita posed a problem of the opposite kind for the Legion. The film was released in Rome in 1960, and was banned by the Vatican because of the kind of lifestyle it portrayed: the swapping of sex partners expressed the decadence of modern society, so clearly criticized by Fellini himself. Despite being banned by the Vatican, it did extremely well in the box office, and even won several prizes - the "Grand Prix" at Cannes, and "Best Picture" by New York Film Critics-. So the Legion had to face a film banned by the Vatican but easily accepted as entertainment by Catholics in the United States. When the board reviewers expressed their opinion, little consensus was reached. In the end, Father Little, the director of the Legion, reported the results of the consultors to Bishop James McNulty:

The majority [76.8 per cent] of our reviewers and consultors judged $L a$ Dolce Vita to be moral in theme and decent in treatment at least for mature audiences. (Black 2001: 87) 
The Legion's final decision was to exhibit the film only in Italian with English subtitles, and of course to restrict it to spectators over 18.

Another controversial film for the Legion was Lolita by Stanley Kubrick. Once again, a serious debate revealed the different opinions of the consultors. After long negotiations the Legion opted to give Lolita a 'Separate Classification' - as they had done with La Dolce Vita - and the film was finally restricted to adults.

The consensus was that the Legion's restrictions had too much to do with personal opinions and beliefs; and as time went by an organization that had been overwhelmingly respected began to be more and more criticized:

Censorship prevented Hollywood from interpreting the morals and manners, the economics and politics, and the social and ethical issues facing American society in direct and honest terms. The industry chose instead to interpret all social and political themes through the restrictive lens of the code. (Black 1994: 299-300)

Little by little, the Catholic Church started changing and becoming receptive to modern films. Going to the movies had become a matter of personal choice.

By 1965, the Legion of Decency had lost its powers and rights in the United States. Nowadays, there is an organization in the US in charge of the ratings system. All motion pictures produced in the US, as well foreign productions have to be regulated and assigned a rating by the Motion Picture Association of America (MPAA). This organism was conceived to help the parents of young children choose the most suitable films for their children. It is composed of a group of parents who are in 
charge of screening the works, discussing them, and then voting on their suitability. The character of this association is said to be non-restrictive, as its members only decide whether or not certain films are appropriate for young audiences. The code used by the MPAA is as follows:

\author{
-G. General Audiences. All ages admitted \\ -PG. Parental Guidance Suggested. Some materials may \\ not be suitable for children \\ -PG-13. Parents Strongly Cautioned. Some material may \\ be inappropriate for children under 13 \\ -R. Restricted. Under 17 requires accompanying parent or \\ adult guardian \\ -NC-17. No one of 17 or under admitted. No ifs, ands or \\ buts.
}

The association also affirms that "the infamous ' $\mathrm{X}$ ' rating" abandoned by the MPAA in September 1990, which accounts for a slight modernization on the part of the US ratings system association. It seems that the censorship now present in the US is not as strong as in recent years; however, there are still certifications of films that restrict some audiences $^{15}$.

\footnotetext{
${ }^{14} \mathrm{http} / / /$ www.bbc.co.uk/dna/h2g2/A220537

${ }^{15}$ I was struck to find out that even on US television channels some scenes in movies were completely suppressed. Watching Dirty Dancing on TNT Channel, I was surprised that some of the scenes that I had already seen in its dubbed version in Spain were not present in the original one. There was a particular scene when Baby goes to Johnny's room and they start to dance. The erotic dance both protagonists engage in is totally omitted in this version. Another movie in which some scenes were suppressed, also on
} 


\subsubsection{Censorship in Spain}

La censura - instrumento politico e ideológico por excelencia (Abellán 1987: 11)

Discretos recortes o podas y hasta maduradas adaptaciones (Toral 1946: 462)

Soon after the Civil War in Spain, Franco's regime created an organism in charge of publications that came from abroad was the Vicesecretaría de Educación Popular, that some time after would become the Subsecretaría de Educación Popular. Since the beginning of the dictatorship, this campaign in charge of 'refining' moral in films was deeply linked to the Catholic church:

Sin embargo, el paso definitivo hacia una única oficina calificadora a nivel nacional (Oficina Nacional Permanente de Vigilancia y Espectáculos) no se dio hasta 1950, cuando la Comisión Episcopal de Ortodoxia y Moralidad, de acuerdo con la Dirección Central de Acción

TNT, was Grease. One could well wonder which scenes could be banned from such a naïve picture, but the Board of the TNT Channel decided to suppress the moment when Danny's friends show their butts to the video camera that is transmitting the high school dance. I also remember the great polemic caused by Basic Instinct, and the two versions commercialized, one for the US and the other for foreign markets. The US version had censured most sexual scenes, whereas the one commercialized abroad included all the controversial scenes. 
Católica, aprobó las Instrucciones y Normas para la Censura Moral de Espectáculos. Este servicio de calificación, considerado el primer código de censura en España, fue publicado [...] y quedaba como sigue: 1.- Todos, incluso niños. 2.- Jóvenes. 3.- Mayores. 3R.- Mayores, con reparos. 4.- Gravemente peligrosa. Cada película, por tanto, era clasificada en uno de estos grupos según su mayor o menor peligrosidad moral. (Gutiérrez 2005: 89)

What the General thought was that "by controlling or influencing what Althusser termed the 'ideological state apparatuses', the ruling elite could influence and shape the values, choices and lived reality of the populace" (O'Leary 2005: 5-6). Some of the taboo subjects during Franco's dictatorship were: "the representation of the army, and more particularly, the rank occupied by the dictator in power, of the elements of the Catholic rite and of unconventional women" (Hurtley 2007: 66).

In principle, censorship acts against what lies in that space between acceptance and refusal: the ambiguous, the composite, and more importantly what disturbs identity, system and order. (Billiani 2007: 22)

Franco created a new organ that was to be in charge of the foreign productions that arrived in Spain: the Ministerio de Información y Turismo. This Ministry "further absorved the functions of all existing censorship organisms, for both foreign and domestic production of fiction and non-fiction alike" (Vandaele 2007: 280). The person in charge of controlling it was Minister Gabriel Arias Salgado.

In Spain the choice of dubbing over subtitling in the 1930s is deeply linked to the sense of nationalism: "it was also a political strategy 
designed to protect Spanish language and culture from foreign contamination" (Ballester 1995: 177). Dubbing was the method favored during Franco's regime, since all imported productions had to be evaluated by the Junta Superior de Censura Cinematográfica ${ }^{16}$ to determine whether they would be released or not. The Junta also favored certain authors and types of literature: it was they who controlled information and filtered cultural products (Merino \& Rabadán 2002). Francoist film translation was "protectionist, untruthful, deceptive and heavily 'domesticating' (Venuti 1998), since it manipulated 'alien' values represented in the original text" (Vandaele 2007: 281):

En algunos casos, los cambios de diálogos se confiaban a un censor cualificado, como ocurrió con las densas reflexiones fílmicas de Ingmar Bergman, que fueron tuteladas en España por la traducción del jesuita y teólogo Carlos María Stahelin, un censor a quien las víctimas de la censura llamábamos Padre Stalin. (Gubert 2001: 85)

Many were the films censored during Franco's regime, and Billy Wilder's productions were among the most punished ones:

\begin{abstract}
Ninguna actividad cultural o textual quedó libre de la influencia de esta omnipresente censura, pues tanto la traducción de textos extranjeros, como la creación original y la adaptación de textos en español (catalán, gallego o vascuence) estaban, desde su origen, condicionadas por la existencia de un filtro universal para todo producto cultural que se ofrecía al público modificado. (Merino 2001: 236-237)
\end{abstract}

\footnotetext{
${ }^{16}$ Committees composed of church representatives, lower-rank officials and men of letters functioning under the supervision of the authorities. (Merino \& Rabadán 2002)
} 
Nevertheless, it is important to mention that 1962 and 1963 were the years in which Spain was moving towards cultural openness (apertura), thanks to which previously taboo elements started to be translated, and film fiction began to experience a feeling of liberalization.

Nowadays, certain ratings may still be found, but the age restrictions are never respected in movie theatres, with the result that the audience is freer to choose and attend the film they like.

XIII. The Reception of Pedro Almodóvar's Films in the $\underline{\text { United States }}$

En el universo de Pedro Almodóvar hay monjas rebeldes, mujeres neuróticas, travestis, transexuales dispuestos a todo y más de un sicópata entrañable. En fin, personajes que siguen la lógica del deseo desenfrenado. Se trata de seres marginales en un mundo de excesos como lo era La Movida española de inicios de los 80. Su cine hilvana un melodrama que ha pasado del kitsch a lo sublime en dos décadas de cine. (Juan F. Jaramillo, La Vida, 1 de Septiembre 2006, Dallas, Texas)

Almodóvar's films have not always enjoyed the same success in Spain they do nowadays. For quite a long time he has received negative critiques here. He has also been considered a second rate director, whose works had no messages to transmit to the Spanish audience, and the treatment of his themes were marked by exaggeration and of bad taste. But it is now acknowledged that his pictures are not expected to deal with common subjects, for they are original in essence and content. Almodóvar has sometimes stated 
that his main goal is not to make shocking movies, rather he says: "I make movies for my needs" (Russo 1988: 15). His constant struggle with Spanish film critics has not affected his way of making films, instead he has continued to produce the movies he likes, and he has finally achieved the recognition of his works in his own country.

Conversely, in every article in US magazines, newspapers, and periodicals, Almodóvar has been praised for his work. And he was not even known in the US when his films were first released in Spain with a minimum success. The fact that he has been so underrated in Europe, and more precisely in Spain, and that his work was unknown outside Spain at the beginning of the 1980s has been a matter of surprise for US film critics (Holland 1998: 39). Some of them blame the rejection of his work by Spanish audiences on the fact that Spaniards have considered them to be “exaggerated jokes" (Cadalso 1988: 36).

The rejection of his work in his home country contrasts with the extraordinary acceptance by US audiences. Perhaps one of the reasons for his acceptance abroad is that US audiences were, and still are, tired of American productions that always deal with the same types of genres, storylines, and endings. His films are different, and respond to a desire of US audiences for a different type of picture:

He's transparent, tasteless, and Spanish, and therefore a quick sell to audiences who like their trash dressed up in European artiness, in pseudo-daring, the more exotic the better. (Cardullo 1991: 645)

Almodóvar's sense of freedom is "very distinctive and daring for his time" (Elgrably 1992: 18). His films are said to be full of energy and 
to embody a refreshing Spanish identity, which has contributed to his increasing success in the US film market (Morgan 1992: 28).

Almodóvar's humor has been catalogued as black humor by some US critics:

Catholicism, the family, emigration, the rural exodus and drug abuse all come into the firing line of his irreverent and transformative black humor. This anarchic brand of humour has a long Spanish pedigree [...]. (Morgan 1992: 28)

It is a special sense of humor, and context in which he places it is also significant. In his films there are examples of violence, scenes in which characters are taking drugs, or engaged in homosexual relationships, but all these are portrayed with black humor.

The main themes in Almodóvar's pictures are death, liberty, equality, beauty and love, with brushstrokes of sex, passion, neurotic urbanities and comedy. His unconventional subject matter, for example the inclusion of "freaky" characters, strange storylines, the presence of sex and drugs, have helped him to "insure the success of his movies in the United States" (Van Meter 1999: 67). There have been many comments and congratulations by critics such as John Waters, who has praised his way of presenting sex. For Waters his films are "gay and straight and all sexualities put together in the best possible way" (in Van Meter 1999: 28). It is as if Almodóvar had attained the almost impossible goal of showing the most bizarre elements as being the most usual ones.

Almodóvar has been compared to Buñuel, Fassbinder, and Douglas Sirk. Although he has always appreciated such positive comparisons, he has detached himself and his movies from these 
directors. As for Buñuel, all they share is their country of origin. Other than that, Buñuel's work has nothing to do with Almodóvar's:

\begin{abstract}
$\underline{\text { He [Buñuel] could do what Almodóvar cannot: combine surreal }}$ fantasy, religious irreverence, sexual commentary, and social criticism in meaningful, passionate ways. Almodóvar's is a camp sensibility out to do little more than express its own sense of homosexual disenfranchisement in a predominantly heterosexual world [.... . (Cardullo 1991: 646)
\end{abstract}

His works have just one thing in common with Sirk's films, and that is the ambiguity of their message. The irony present in Almodóvar's work is not present in Sirk's. And when the Spanish director is compared with Fassbinder, the only thing they had in common, according to Almodóvar, is their physical appearance: "Fassbinder was fat, like me $[\ldots]$, but we had nothing else in common" (Bayón 1989: 60). He also recalls Fassbinder's suicidal desperation which he does not possess, as well as the fact that his films are less existentialist than those of Fassbinder (ibid). The only characteristic that may link him with the German director would be that he is "the most talked about European director since the emergence of Fassbinder" (Ansen 1988b: 88). Other than that, the two filmmakers have nothing in common in terms of making movies. On the contrary, Almodóvar's works display his personal liking for Billy Wilder's comedies, as well as his inspiration derived from early Technicolor and Doris Day domestic comedies (Young 1990: 125). His preference for American comedies of the 50s and 60s is patent in Mujeres al borde de un ataque de nervios (1988) (Pitt 1988: 28). The New York photographer Garfunkel -also a friend of Almodóvar's stated that the Spanish filmmaker bears some resemblance to Andy 
Warhol, and others have compared him with John Waters (Van Meter 1999: 69).

As regards his characters, Almodóvar is "known for putting hard-to-believe characters, especially women in his films" (ibid). Most of his characters personify features that may seem strange to the audience - something he seeks deliberately, as he himself affirms:

All the freaks look up to me [...]. I remember in Rome, the most incredible fat girls that you can imagine came to my hotel. I've become sort of like the Saint of the Freaks. (Almodóvar's words, in Van Meter 1999: 69)

After Franco's death, the film industry in Spain underwent a radical change because of the new form of government that followed fascism. Spanish film-makers started shooting movies whose content was still anchored in the past, as most motion pictures dealt with the recent Spanish Civil War. There seemed to be no desire to focus on the future, only a certain desire to fix one's vision of the past. The Spanish Government started giving funds to those projects which, in their opinion, were worthy. Film-makers started a new fashion for adapting respectable novels for the screen: "What looked better than an adaptation for the screen of a respectable novel?" (Cadalso 1988: 36). The results of these adaptations were extraordinary, as they received awards and good reviews all over Europe (ibid). However, their themes were not attractive to audiences, which was a problem for the film industry. And it was at that moment, the beginning of the 80s, that Almodóvar made his appearance:

His uncontrolled and colourful films found a receptive audience in a population that was eager for spontaneity and light, for new 
stimuli could again bring joy to living. $[\ldots]$ Almodóvar $[\ldots]$ dared to show on screen all the passion that previously had been politically impossible for Spanish society or its arts to express. (ibid)

Nevertheless, the change the director would bring to the filmic panorama was not appreciated and praised until some time later. The film maker had to succeed abroad before his own country could realize the worth of his works (Elgrably 1992: 21), and his success in Spain was the result of his success and acceptance abroad (Cadalso 1988: 36).

The starting point of Almodóvar's success in the US film panorama was the release of Mujeres al borde de un ataque de nervios $^{17}$ (1988). This international triumph brought him an immediate and lasting success in the US film market. The movie opened in 1988 at the $26^{\text {th }}$ New York Film Festival, where the filmmaker was honored by the New York Film Critics Circle and by the National Board of Review of the US (Bayón 1989: 60). The film soon became an international hit and raised around $\$ 2,5$ million in ten weeks of limited US release (Corliss 1989: 68). He also gained recognition with US audiences, not only in experimental film circles, but also among cinema-goers all over the US. The rapid recognition and admiration for Mujeres encouraged audiences to rush into Blockbusters looking for other movies by him. His most sought after work then was Matador (1986), and its discovery increased admiration for the Spanish director (Menard 1998: 32). The following year Mujeres was nominated for the Academy Awards as Best Foreign Language Film, and even though it did not win the

${ }^{17}$ I will refer to this movie as Mujeres from now on. 
Oscar, its fame spread all over the US. It seemed that in the 1980s "the world was ready for saucy Pedro, or anyone with cojones for that matter" (O'Toole 1990: 270).

Mujeres was praised by every film critic in the US, and it received positive and constructive comments, since it "allowed audiences worldwide a benign fantasy of sexual playfulness" (O’Toole 1990: 270), and Almodóvar had clearly appeared on the US scene at the right time and "bearing the bracing news at the idea of sex isn't so dangerous" (O'Toole 1990: 271), as his film departed somewhat from the previous US tradition of keeping sex away from pictures. The film even broke house records in New York, and surprisingly it also became a big hit in Spanish box offices. It seemed as if Spain had started to accept and enjoy Almodóvar's work. The film was described as "anything but overtly political", and "a romp by turns sentimental madcap about a liberated woman who learns from an answering machine that she is being abandoned by her macho lover" (Pitt 1988: 1). It was also praised as "the most colourful, most accessible, and funniest film to date", which was "exclusively about women and their willingness to express dangerous emotion, illustrating his firm conviction that 'men cry, but I think women cry better"' (Russo 1988: 14). It is with Mujeres that he shows his preference for representing the world of women over that of men. With it, he delights audiences with a theme that had always interested him: "the universal problem of abandonment and loneliness" (Pitt 1988: 28), and even though it starts as a drama - the desperation of the female protagonist - , it develops into a comedy as the storyline progresses. Almodóvar asserted that he had found an inspiration in Jean Cocteau's La Voix Humaine, as well as in the American comedies of the 50s and 60s (Pitt 1988: 28) while writing the script. 
Matador (1986) was first released in 1988 in Los Angeles - two years after its release in Spain -, thanks to the success and recognition of Mujeres. The reaction of the audience and critics was unexpected: the main responses were "between those who roared with laughter and those who took it with dead earnestness" (Ansen 1988b: 88). This diversity of reaction did not surprise the film-maker since, as he stated, "everything's serious and everything's comic at the same time" (ibid). Matador was also considered to reflect a new Almodóvar "aesthetically slick, deeply romantic, short on laughs, and, yes, pretentious" (Holland 1988: 39).

¿Atame! (1990) was considered his master stroke in the US, and since the release "American critics and audiences have been hooked on Almodóvar" (Menard 1998: 32). The film showed a world full of tormented characters, and was considered as the antithesis of Mujeres in some sense. With it, Almodóvar "has tried something different, using a background of violence to tell a real love story yes, of a man and a woman - in which in his own words, 'tie me up means I love you"' (Riding 1990: 34). ¿Átame! is about social outsiders where unorthodox characters find themselves in a world of romantic comedy (Kauffman 1990: 30). Negative reviews showed up and considered the appearance of a picture with a strong religious content as being a transparent insult to Spanish religiosity (Klawans 1990: 754). But the most important aspect of the release of this film in the US was that it became a cause-célèbre since the MPAA (Motion Picture Association of America) gave the film an X-rating. This X-rating "guaranteed an even smaller audience than subtitled films usually receive" (Young 1990: 25). Almodóvar's reaction was immediate: he felt hurt and terribly upset, considering the $X$-rating to be "ridiculous and hypocritical" (ibid), and blamed the MPAA for acting as censors. The Spanish director together with his US 
distributor, Miramax, accused MPAA of having acted "arbitrarily and capriciously" (Elgrably 1992: 21), and they sued the MPAA for such an unfair rating.

The fact is that the most controversial scene of ;Atame! was the love scene between Ricky (Banderas) and Marina (Abril):

As evidence, Miramax screened the controversial sex scene between Antonio Banderas and Victoria Abril for a New York judge, along with a selection of erotic scenes from such R-rated film as "9 1/2 Weeks" and "Fatal Attraction", suggesting that "Tie me up!" was no more likely than those films to encourage depravity. In the end, the judge refused to overturn the $\mathrm{X}$-rating, and "Tie me up!" was released unrated. (ibid)

Almodóvar fought for his convictions and finally won. In Spain, the responses and reactions of film critics to ;Atame! were varied. Angel Fernández Santos (El País) affirmed that it had "both good and bad moments which, in the end, made it an unbalanced work, above all in structure" (Riding 1990: 34). On the other hand, Carlos Boyero (El Mundo) "praised the work as 'admirable and moving', saying it combined the grace of Mujeres with the strength and 'militant sadness' of ¿Qué he hecho yo para merecer esto?" (ibid).

Tacones lejanos (1991) was extraordinarily successful and received excellent critiques in Europe and the US. As expected, its acceptance in Spain was somehow different: it seemed that Tacones lejanos "perturba extrañamente a sus compatriotas que no siempre saben catalogar su producción" (Saz 1992: 575). Some critics judged it severely: Rafa Fernández $(E l$ Sol) affirmed: "pasa por ser un musical dramático bastante cutre, un melodramazo de los de antes del gasógeno, hasta un intento frustrado de Imitación a la vida (1959) 
de Douglas Sirk" (ibid). Quim Casas (El Periódico) stated that it was "un cóctel con sabor a folletín [...], un melodrama de calidad mediana tirando a baja [...] a distancias astronómicas de las cumbres del género más refinado que existe" (ibid). Similarly, the controversial writer Francisco Umbral declared that with Tacones lejanos "Almodóvar ha querido hacer al mismo tiempo un culebrón y la sátira de un culebrón" (Saz 1992: 576), an effect that is not achieved. In addition to these critiques dealing with the genre of Tacones lejanos, Rafa Fernández goes even further and criticizes Almodóvar's works in general:

"Los filmes de este director pecan siempre de lo mismo y ésta es la vez que adolece más de narración truculenta, enrevesada, telenovela al uso para el consumo directo de gentes sin el mínimo EGB o la siempre ponderada y falsa lectura de un yuppy cutre que trata de destacar antropológicamente...todo cuando subyace de tercermundista de este tipo de relato" (In Saz 1992: 575)

On the other hand, other film critics deemed the quality of the film to be good. According to Pere Vall, Tacones lejanos is not a “culebrón", as Almodóvar himself stated, but a melodrama (ibid). An anonymous critic certified the influence of Sirk in it, and also pointed out "la conexión deliberada entre Tacones y Sonata de Otoño, película de Ingmar Bergman que también trata la relación compleia de una madre famosa, en este caso concertista de piano, $y$ su hija menos talentosa, y que cita expresamente Rebeca en Tacones" (ibid). Faced with these critiques that had relegated Tacones Lejanos to the soap opera genre, the Spanish director firmly declared his personal dislike and rejection of such a genre as being "una auténtica porquería", thus agreeing that its growing popularity in 
Spain reflected "un atraso cultural" (ibid). Kaufman's opinion (1992b: 28) of Tacones leianos was that "the cleverness is sparse and the wickedness has fattened into melodrama". For him there is only one worthwhile feature: "the only charm is the daughter, Victoria Abril, who was the porno star in Tie Me Up! Tie Me Down! and whose sparkle does not fade" (ibid). Corliss (1992: 76) states that Tacones lejanos "careers like a runaway circus train over the rickety trestle of melodrama. Between giggles at the absurdity of it all, you're welcome to shudder". As regards sexual scenes, Jahiel ${ }^{18}$ draws attention to the one that takes place between Rebeca (Victoria Abril) and Lethal (Miguel Bosé):

Sex permeates the movie. There is, early on, a memorable, unexpected, funny, and acrobatically erotic scene between Rebecca and Femme Lethal. The previous scene takes place at the stage of the place where Lethal works. He imitates by means of a play-back a song by Rebeca's mother entitled "Un año de amor" while Lethals devotees mime right along his/her own imitation of Becky. Shades of The Rocky Horror Picture Show.

His first work Pepi, Luci, Bom y otras chicas del montón (1980) has so far been neither very popular nor widely seen in the US. Nevertheless, the film received some critiques:

It shows all the signs of cheap production: cinematography that's almost amateurish, erratic editing, a sound track that isn't quite perfection. $[. .$.$] and if there were an award for bad taste -$ chinaware Oscar, perhaps - this film should get it. (Kauffman 1992a: 28)

\footnotetext{
${ }^{18}$ In http://www.prairienet.org/ejahiel/highheel.htm
} 
Kauffman is right when he says that Almodóvar was at that time on a tight budget, and this, in addition to his insufficient experience, explains why the editing of the film was not as good as it is nowadays.

Laberinto de pasiones (1982) is a parody of the passion some Spaniards show when it comes to reading gossip magazines (Cadalso 1988: 36). It was considered a perfect reflection of the explosion of excess that accompanied the new Spain after Franco's death. Spain opened its borders to tourism and new lifestyles, and what had been forbidden and hidden for such a long time now started to open up. Sex began to be openly expressed, including homosexual relationships. With ¿Qué he hecho yo para merecer esto? (1984), the director's name "started to trickle into the international consciousness" (Holland 1998: 39); ¿Qué he hecho yo para merecer esto? and Matador were described as having "a kaleidoscopic quality, mixing moments of brooding drama with bizarre, often ribald, satire" (Pitt 1988: 28). For some experts, ¿Qué he hecho yo para merecer esto? was Almodóvar's most realistic work at that time. In it, he "includes cultural references and plays with Spanish stereotypes" (Cadalso 1988: 37), and these aspects may be the "reason why foreign audiences identify his imaginative stories with the current situation in Spain" (ibid). On the other hand, the film was also severely criticized:

[The film] is like a skilful team of comic acrobats, tumbling away furiously, defying laws of gravity [.... laugh once. (Kauffman 1985: 24) 
Entre tinieblas (1983) was shown to New York audiences in May 1988, and it was regarded as his first black comedy (Pitt 1988: 28), being described as a "lunatic story about a convent where very open-minded nuns try to redeem delinquent girls" (Cadalso 1988: 36). Its black humor lies in the grotesque appearance of corrupt nuns who are addicted to cocaine, and whose actions break all the rules.

In 1987 La lev del deseo (1987) was first shown in New York, and at that time this film and Matador were regarded as his most shocking movies so far, as they "inaugurate a more elaborate visual language" (Cadalso 1988: 37). Some critics stated that Almodóvar's achievement of cult status in the US was due to La lev del deseo and ¿Oué he hecho yo para merecer esto? (Reynaud 1988: 72). The opening scene of La lev del deseo shows a sequence in which a man is being sexually aroused by a male voice. As an opening scene it was regarded as shocking by some people, and for whom it produced a feeling of discomfort (Russo 1988: 15-16). When the film was screened at the Museum of Modern Art (MOMA), it "was immediately criticized by a well-known cinematographer as shocking for 'promoting homosexuality in this day and age', an obvious reference to the AIDS crisis" (ibid).

Kika (1993) represents a radical change in Almodóvar's work, and he himself described it as a "iigsaw" due to its narrative. Romney (1994: 33) notes this shift in Almodóvar's work:

Now the flouting of the narrative coherence and the courting of shock value are so transparent that it looks as though EI Deseo is running a sort of market survey to see which tricks work.

Whereas his previous films dealt with themes that are particularly Spanish, Kika is not a perfect representation of such Spanishness, 
nor do its characters resemble any other roles from previous films. In fact, "he has more thoroughly than ever before placed his characters in a world of pure cinema" (Levy 1994: 60). Other critics have not seen anything positive and worth praising in Kika:

Kika on the whole shows a weakness in Almodóvar. Often he is irreverent about stupidities in society, but sometimes he is merely irreverent. (Kauffman 1994: 27)

The modernity the director has achieved in the film was also praised:

The violent chic décor, unblinking sexual liberty, and hyperbolically trashy television programs he puts into Kika are presented as conditions common to all post-industrial metropolises. (ibid)

The attitude the film-maker adopts is "proof that the Iron Mantilla separating Spain from Western Europe and the US has fallen away without a trace" (ibid), but for US audiences there has never been such an "iron mantilla" because of the rapid and permanent acceptance of his films all over the States.

La flor de mi secreto (1995) is regarded as the point of departure from his earlier work ${ }^{19}$. It represents the struggle of a weak woman, Leo - played by Marisa Paredes -, trying to recover from a failed marriage. Her sense of desperation and defeat can only be overcome by the figure of the mother. In this there are none of Almodóvar's "freaky" characters, or surreal plots, and it marks a radical shift in his career. He explained that "this movie demonstrates that I'm as free as always, as independent as always -

${ }^{19}$ Michael Warren in http://www.canoe.ca/JamMoviesArtistsA/almodovar.html 
so independent that I can be serious when I want to" $" 20$ : La flor de mi secreto does not contain the particular doses of humor present in other films.

In 1997 Almodóvar made an adaptation of the novel Live Flesh by the British author Ruth Rendell that resulted in Carne trémula, a film that also keeps the novel's title in the English version. It could be said to be his only work in which the past and present of the two Spains, so common in his productions, are explicitly juxtaposed. It opens with a sequence from the Franco era in which a birth takes place, and ends with the birth of another baby in the post-Franco era, with a direct allusion to those times of repression, lack of freedom and prohibitions suffered by Spaniards for such a long time:

Mira cómo está la acera. Llena de gente. Cuando yo nací no había un alma por la calle. La gente estaba encerrada en su casa, cagada de miedo. Por suerte para ti, hijo, hace ya mucho tiempo que en España hemos perdido el miedo. (Víctor in Carne trémula)

The film was regarded as less audacious and more conservative than his previous productions, probably because "the message of freedom on the personal level speaks to a larger segment of the Spanish population" (Deveny 2000: 130).

The 2000 Oscar-winner Todo sobre mi madre (1999) was regarded as one of his most moving films. It was said to represent an "enormous transition for the bad boy of Spanish cinema" (Blake 2000: 21), as well as “Almodóvar's passionate redefinition of family values" (Ansen 1988a: 91). Kenneth Turan, a critic of Times, defined it as "a surprisingly satisfying combination of bawdy sexual humor, 
genuine emotion and a plot with mechanisms so excessive that Almodóvar himself calls it a 'screwball drama""21. For others, the film emanated freshness as well as "unconventional images of Spain and Spaniards" (D'Lugo 2002: 3). The argument of Todo sobre mi madre was described by Stuart:

\begin{abstract}
About the kindness of strangers, how random acts of compassion can transform, civilize, and redeem. All of the women Manuela encounters are, like herself, in great pain; all of them are rescued by sisterly love. (Stuart 1999: 87)
\end{abstract}

The way the director represents such themes is nothing if not original: "who else but he could combine in one picture a pregnant nun, a heroin-addicted lesbian actress and a transvestite father with AIDS?" (Turan ${ }^{22}$ ). Many professionals did not expect such a different kind of film, and some even stated that it was the director's most complete work so far (Romney 1999: 31), insinuating that the rest of his productions were unfinished. Whereas his previous characters embodied excesses, the characters in this production are "more fully human, in effect using melodrama as a vehicle for creating emotion that is deeper than we may be expecting" (Turan ${ }^{23}$ ). Others confirmed that with this film the director had established himself as a "major postmodern artist", as "he bases this current film not only on life, but on his audience's familiarity with earlier artifacts whose themes he can reiterate, examine and modify" (Blake 2000: 21). The film has also been regarded as indicative of Almodóvar's growth as an artist:

\footnotetext{
${ }^{21} \mathrm{http} / /$ events.calendarlive.com/top/1,1419,L-LATimes-Movies-X!

22 ibid

${ }^{23}$ ibid
} 
In the earlier films, he seemed to visit the world of prostitutes, lechers and drag queens on a tourist visa. They were clowns, mere spectacles presented to visitors as a kind of morbid amusement to be enjoyed at a distance. In this film, by contrast, he shows a profound humanism $[\ldots]$, but more a zany postmodern humanism of non-judgmental respect. (Blake 2000: $\underline{23)}$

\begin{abstract}
Almodóvar's reputation of being a "woman's director" is evident in this film, as it represents the lives and struggles of women. With the release of Todo sobre mi madre, the director fully established his career in the US. Its nomination and winning of the Oscar for Best Foreign Film in 2000 intensified admiration of his works by critics and audiences in general. With Todo sobre mi madre he wanted to make a picture exclusively about women, and a tribute to all those people who act, and especially to his mother, who unexpectedly died just as he was achieving the worldwide recognition the director had always longed for:
\end{abstract}

A Bette Davis, Gena Rowland, Romy Schneider...A todas las actrices que han hecho de actrices. A todas la mujeres que actúan. A los hombres que actúan y se convierten en mujeres. A todas las personas que quieren ser madres. A mi madre. (Almodóvar 1999: 122)

From 2000 onwards, Almodóvar's career has been more prolific. Hable con ella (2001) was a great success in the US and Europe, its reviews even more positive than previous ones of Todo sobre mi madre. While US audiences love his work, and its box offices rating is high, Spanish audiences have not shown the same enthusiasm - a fact that brings disillusion to the film director: 
"Es extraño que España hava sido, comparativamente, el país en el que Hable con ella ha funcionado peor, con 1,5 millones de euros [...]. Reconozco que hay gente que le cuesta verme con cierta objetividad, valorar mi película desde un punto de vista meramente cinematográfico. Quizás es que están cansados de verme" (Heraldo de Aragón, 21 January 2003)

Despite the increasing acceptance of his films in Spain, he still has to face the rejection and sometimes painful ignorance of some audiences. Nevertheless, Hable con ella has won several prizes all over Europe and the US, and 2003 was an important year for Almodóvar. At the Cesar's ceremony in France, Hable con ella was honored with the Cesar for Best European Film. The director gratefully thanked the jury for this prize:

"Quiero agradecerles su generosidad y espero que esta historia de amor no termine nunca. Muchas gracias a todos. Estoy muy contento de ser europeo en este momento". (El Mundo, 23 February 2003)

At the ceremony of the British Academy Film Awards, Hable con ella won the BAFTA awards for Best Film not in the English Language, as well as Best Screenplay (Original). The film also won the Golden Globe award as Best Foreign Film - as Todo sobre mi madre did in 2000. At the same ceremony, Almodóvar thanked US audiences for "Ia falta de prejuicios con la que han acogido la cinta" (El Mundo, 24 January 2003), prejudices that Spanish audiences still show. The nominations for the 2003 Film Academy awards surprised Almodóvar's supporters because of the two new nominations Hable 
con ella had received: Best Written Screenplay and Best Achievement in Directing. It finally won the Best Written Screenplay award.

The critiques of the film have been exceptional:

Es el trabajo más duro que su director ha llevado a la pantalla. $\underline{\text { Su audacia solía prestarse a argumentos tan extraños y radicales }}$ que podían hacer pensar que el director se estaba riendo de sí mismo, una especie de director cómico que le gustaba hacer películas como sin prestarles demasiada atención. ${ }^{24}$ (Elvis Mitchell, New York Times)

The film reflects the director's peak of serenity and constitutes "la evidencia de la evolución de su sensibilidad"25. The Familiar Cineaste $^{26}$ focuses on the dark and serious tone of the film, and some experts have affirmed that Almodóvar focuses on less sex, however, according to the director himself, this choice was not conscious:

A lot here is different. I didn't know that there was no sex, no drugs. Someone said to me, 'Pedro! Do you realize that this movie can be seen by our nephews?'. (Valby 2002: 34)

With his last two films so far, La mala educación (2004) and Volver (2006) Almodóvar has received lots of nominations and awards that can be seen in section 2.2.1, together with the nominations and awards of all his works.

The director has finally achieved great success both in Europe and the US, unlike Spain where his work continues to be rejected,

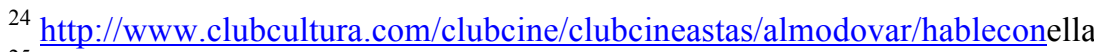

${ }^{25}$ ibid

${ }^{26} \mathrm{http}: / / \mathrm{www} . v a r i a g a t e . c o m / t a l k 2 h e r . h t m$
} 
though his acceptance there is slowly growing. He has been praised as being one of the few Spanish film-makers to have won critical attention, and to have achieved great success in box offices in the US (Morgan 1992: 28), which has to do with the enthusiasm US audiences show towards his productions. The themes, mostly dealing with human passions, and his special sense of humor that encourages the spectator to laugh at the inconveniences of life, are appealing to these audiences (Menard 1998: 32). Admiration for his characters is part of this charm:

He leads audiences to admire them in hopes that they will find sympathy for the more modest desires of their neighbors and themselves. (Pally 1988: 33)

The high rate of approval and the positive reaction that American audiences showed towards Almodóvar's works from the very beginning of his career surprise some of Spain's movie-going public, who have been unable to catalogue his films or to understand the messages they transmit. These reactions will probably never be overcome. Whereas Spanish audiences and critics might have been expected to be proud and to show support for his productions, which are extremely Spanish in content, it was American audiences and critics who discovered Almodóvar's possibilities and virtues. It is not that he chooses strange themes and strange ways of representing them, as he has specified, "what interests me most is the contemporary, what $I$ see in the streets, how it relates to this time and this place". It seems that some Spaniards have not been able to discern and admire this way of representing reality. Instead, it has taken time and recognition from abroad for Spanish audiences and critics to understand and appreciate what they have always had in their midst. 


\begin{tabular}{|c|c|c|c|c|c|}
\hline \multicolumn{6}{|c|}{ 2.2.1. Almodóvar's Films: Nominations and Awards } \\
\hline YEAR & FILM & RESULT & FESTIVAL & AWARD & CATEGORY \\
\hline 2007 & Volver & Nominated & $\begin{array}{ll}\text { Film Academy } \\
\text { Awards }\end{array}$ & Oscar & Best Actress \\
\hline 2007 & & Nominated & $\begin{array}{l}\text { César Awards, } \\
\text { France }\end{array}$ & César & Best Foreign Film \\
\hline 2006 & & Winner & Goya Awards & Goya & Best Film \\
\hline 2006 & & Winner & Goya Awards & Goya & Best Director \\
\hline 2006 & & Winner & Goya Awards & Goya & Best Actress \\
\hline 2006 & & Winner & Goya Awards & Goya & $\begin{array}{l}\text { Best Supporting } \\
\text { Actress }\end{array}$ \\
\hline 2006 & & Nominated & Goya Awards & Goya & $\begin{array}{l}\text { Best Supporting } \\
\text { Actress }\end{array}$ \\
\hline 2006 & & Nominated & Goya Awards & Goya & $\begin{array}{l}\text { Best Supporting } \\
\text { Actress }\end{array}$ \\
\hline 2006 & & Nominated & Goya Awards & Goya & \begin{tabular}{|ll} 
Best & Origina \\
Script & \\
\end{tabular} \\
\hline 2006 & & Nominated & Goya Awards & Goya & \begin{tabular}{|l|} 
Best Production \\
Supervision
\end{tabular} \\
\hline 2006 & & Winner & Goya Awards & Goya & \begin{tabular}{|ll} 
Best & Music \\
Original & \\
\end{tabular} \\
\hline 2006 & & Nominated & Goya Awards & Goya & $\begin{array}{l}\text { Best Screenplay } \\
\text { Original }\end{array}$ \\
\hline 2006 & & Nominated & Goya Awards & Goya & Best Art Direction \\
\hline 2006 & & Nominated & Goya Awards & Goya & \begin{tabular}{|ll} 
Best & Costum \\
Design & \\
\end{tabular} \\
\hline 2006 & & Nominated & Goya Awards & Goya & Best Photography \\
\hline 2006 & & Nominated & Goya Awards & Goya & $\begin{array}{l}\text { Best Make-up anc } \\
\text { Hairstyles }\end{array}$ \\
\hline 2006 & & Nominated & Goya Awards & Goya & \begin{tabular}{|ll} 
Best & Costum \\
Design & \\
\end{tabular} \\
\hline 2006 & & Nominated & Goya Awards & Goya & Best Sound \\
\hline 2006 & & Winner & Cannes Festival & & $\begin{array}{l}\text { Best Actress } \\
\text { (Group of } \\
\text { Actresses) }\end{array}$ \\
\hline 2006 & & Winner & Cannes Festival & & \begin{tabular}{|l|l|} 
Best Screenplay \\
Original
\end{tabular} \\
\hline
\end{tabular}




\begin{tabular}{|c|c|c|c|c|}
\hline 2006 & Winner & Cannes Festival & FIPRESCI & $\begin{array}{l}\text { Best Film of the } \\
\text { Year }\end{array}$ \\
\hline 2006 & Nominated & $\begin{array}{ll}\text { European } & \text { Film } \\
\text { Awards } & \end{array}$ & & $\begin{array}{l}\text { Best European } \\
\text { Film }\end{array}$ \\
\hline 2006 & Winner & $\begin{array}{l}\text { European } \\
\text { Awards }\end{array}$ & & Best Director \\
\hline 2006 & Winner & $\begin{array}{l}\text { European } \quad \text { Film } \\
\text { Awards }\end{array}$ & & Best Actress \\
\hline 2006 & Winner & $\begin{array}{ll}\text { European } & \text { Film } \\
\text { Awards } & \end{array}$ & & Best Composer \\
\hline 2006 & Nominated & $\begin{array}{ll}\begin{array}{l}\text { European } \\
\text { Awards }\end{array} & \text { Film } \\
\end{array}$ & & Best Photography \\
\hline 2006 & Winner & $\begin{array}{ll}\text { European } & \text { Film } \\
\text { Awards } & \end{array}$ & $\begin{array}{l}\text { People's } \\
\text { Choice to the } \\
\text { Best European } \\
\text { Film }\end{array}$ & $\begin{array}{l}\text { Best European } \\
\text { Film }\end{array}$ \\
\hline 2006 & Winner & $\begin{array}{l}\text { Círculo de } \\
\text { Escritores } \\
\text { Cinematográficos } \\
\text { (CEC) }\end{array}$ & CEC Award & Best Film \\
\hline 2006 & Winner & $\begin{array}{l}\text { Círculo de } \\
\text { Escritores } \\
\text { Cinematográficos } \\
(\mathrm{CEC})\end{array}$ & CEC Award & Best Director \\
\hline 2006 & Winner & $\begin{array}{l}\text { Círculo de } \\
\text { Escritores } \\
\text { Cinematográficos } \\
(\mathrm{CEC})\end{array}$ & CEC Award & Best Actress \\
\hline 2006 & Winner & $\begin{array}{l}\text { Círculo de } \\
\text { Escritores } \\
\text { Cinematográficos } \\
\text { (CEC) }\end{array}$ & CEC Award & $\begin{array}{l}\text { Best Supporting } \\
\text { Actress }\end{array}$ \\
\hline 2006 & Winner & $\begin{array}{l}\text { Círculo de } \\
\text { Escritores } \\
\text { Cinematográficos } \\
\text { (CEC) }\end{array}$ & CEC Award & $\begin{array}{l}\text { Best Screenplay } \\
\text { Original }\end{array}$ \\
\hline 2006 & Winner & $\begin{array}{l}\text { Círculo de } \\
\text { Escritores } \\
\text { Cinematográficos } \\
\text { (CEC) }\end{array}$ & CEC Award & Best Soundtrack \\
\hline 2006 & Winner & $\begin{array}{l}13^{\circ} \text { Festival } \\
\text { Internacional de } \\
\text { Cine de Valdivia } \\
\text { (Chile) }\end{array}$ & $\begin{array}{|lr|}\text { Premio } & \text { del } \\
\text { Público } & \mathrm{y} \\
\text { Especial } & \text { del } \\
\text { Jurado } & \end{array}$ & Best Film \\
\hline 2007 & Winner & $\begin{array}{ll}\text { Hollywood } & \text { Film } \\
\text { Festival }\end{array}$ & & Best Actress \\
\hline
\end{tabular}




\begin{tabular}{|c|c|c|c|c|c|}
\hline 2006 & & Winner & \begin{tabular}{|ll} 
Academia de las \\
Artes y las \\
Ciencias \\
Cinematográficas \\
\end{tabular} & & $\begin{array}{l}\text { To Represent } \\
\text { Spain at Academy } \\
\text { Awards }\end{array}$ \\
\hline 2005 & $\begin{array}{l}\text { La mala } \\
\text { educación }\end{array}$ & Nominated & BAFTA Awards & $\begin{array}{l}\text { BAFTA Film } \\
\text { Award }\end{array}$ & Best Foreign Film \\
\hline 2005 & & Nominated & $\begin{array}{l}\text { International } \\
\text { Online Cinema } \\
\text { Awards }\end{array}$ & & Best Foreign Film \\
\hline 2005 & & Nominated & $\begin{array}{l}\text { César Awards, } \\
\text { France }\end{array}$ & César & Best EU Film \\
\hline 2005 & & Winner & \begin{tabular}{|l} 
Italian National \\
Syndicate of Film \\
Journalists
\end{tabular} & Silver Ribbon & $\begin{array}{l}\text { Best Foreign Film } \\
\text { Best Director }\end{array}$ \\
\hline 2005 & & Nominated & $\begin{array}{l}\text { Círculo de } \\
\text { Escritores } \\
\text { Cinematográficos } \\
(\mathrm{CEC})\end{array}$ & CEC Award & \begin{tabular}{|l} 
Best Actor \\
Best Score \\
Best Editing
\end{tabular} \\
\hline 2005 & & Nominated & $\begin{array}{l}\text { Independent Spirit } \\
\text { Awards }\end{array}$ & $\begin{array}{l}\text { Independent } \\
\text { Spirit Award }\end{array}$ & Best Foreign Film \\
\hline 2005 & & Nominated & $\begin{array}{l}\text { Argentinean Film } \\
\text { Critics Association } \\
\text { Awards }\end{array}$ & Silver Condor & Best Foreign Film \\
\hline 2005 & & Winner & Chlotrudis Awards & $\begin{array}{l}\text { Chlotrudis } \\
\text { Award }\end{array}$ & Best Actor \\
\hline 2005 & & Nominated & Chlotrudis Awards & $\begin{array}{l}\text { Chlotrudis } \\
\text { Award }\end{array}$ & Best Movie \\
\hline 2005 & & Nominated & $\begin{array}{l}\text { Directors Guild of } \\
\text { Great Britain }\end{array}$ & DGGB Award & $\begin{array}{l}\text { Outstanding } \\
\text { Directorial } \\
\text { Achievement in } \\
\text { Foreign Language } \\
\text { Film }\end{array}$ \\
\hline 2005 & & Nominated & \begin{tabular}{|l|} 
European Film \\
Awards \\
\end{tabular} & $\begin{array}{l}\text { Audience } \\
\text { Award }\end{array}$ & \begin{tabular}{|l|} 
Best Actor \\
Best Director \\
\end{tabular} \\
\hline 2005 & & Nominated & $\begin{array}{l}\text { European Film } \\
\text { Awards }\end{array}$ & $\begin{array}{l}\text { European } \\
\text { Film Award }\end{array}$ & \begin{tabular}{|l|} 
Best \\
Cinematographer \\
Best Composer \\
Best Director \\
Best Film \\
Best Screenwriter \\
\end{tabular} \\
\hline 2005 & & Winner & $\begin{array}{l}\text { GLAAD Media } \\
\text { Awards } \\
\end{array}$ & $\begin{array}{l}\text { GLAAD } \\
\text { Media Award }\end{array}$ & Outstanding Film \\
\hline 2005 & & Winner & Glitter Awards & Glitter Award & \begin{tabular}{|l} 
Best Actor \\
Best Feature \\
Best Picture \\
\end{tabular} \\
\hline
\end{tabular}




\begin{tabular}{|c|c|c|c|c|c|}
\hline 2005 & & Nominated & $\begin{array}{l}\text { Polish Film } \\
\text { Awards }\end{array}$ & Eagle & $\begin{array}{l}\text { Best European } \\
\text { Film }\end{array}$ \\
\hline 2005 & & Winner & $\begin{array}{l}\text { Spanish Actors } \\
\text { Union }\end{array}$ & $\begin{array}{l}\text { Award of the } \\
\text { Spanish } \\
\text { Actors Union }\end{array}$ & $\begin{array}{l}\text { Film: Performance } \\
\text { in a Minor Role, } \\
\text { Male }\end{array}$ \\
\hline 2005 & & Nominated & $\begin{array}{l}\text { Spanish Actors } \\
\text { Union }\end{array}$ & $\begin{array}{l}\text { Award of the } \\
\text { Spanish } \\
\text { Actors Union }\end{array}$ & \begin{tabular}{|l} 
Film: Lead \\
Performance, \\
Male
\end{tabular} \\
\hline 2005 & & Nominated & $\begin{array}{l}\text { Golden Satellite } \\
\text { Awards }\end{array}$ & \begin{tabular}{|l|} 
Golden \\
Satellite \\
Award
\end{tabular} & \begin{tabular}{|l} 
Best Motion \\
Picture Foreign \\
Film
\end{tabular} \\
\hline 2005 & & Nominated & Goya Awards & Goya & \begin{tabular}{|l|} 
Best Film \\
Best Director \\
Best Production \\
Design \\
Best Production \\
Supervision \\
\end{tabular} \\
\hline 2004 & & Nominated & $\begin{array}{l}\text { People Choice } \\
\text { Awards }\end{array}$ & EFA & \begin{tabular}{|l} 
Best Film \\
Best Director \\
Best Screenplay \\
Best Music \\
Best Photography \\
Best Director \\
(People Choice) \\
Best Actor \\
(People Choice)
\end{tabular} \\
\hline 2004 & & Nominated & $\begin{array}{l}\text { London Film } \\
\text { Critics Circle }\end{array}$ & LFC Award & Best Foreign Film \\
\hline 2004 & & Nominated & $\begin{array}{l}\text { BBC World } \\
\text { Cinema Circle }\end{array}$ & \begin{tabular}{|l|} 
BBC World \\
Cinema \\
Award \\
\end{tabular} & Best Foreign Film \\
\hline 2004 & & Nominated & Nastro D'Argento & & Best Foreign Film \\
\hline 2004 & & Winner & $\begin{array}{l}\text { La navaja de } \\
\text { Buñuel }\end{array}$ & & Best Spanish Film \\
\hline 2004 & & Winner & $\begin{array}{l}\text { New York Film } \\
\text { Critics Circle }\end{array}$ & $\begin{array}{l}\text { NYFCC } \\
\text { Award }\end{array}$ & $\begin{array}{l}\text { Best Foreign } \\
\text { Language Film }\end{array}$ \\
\hline 2004 & & Winner & $\begin{array}{l}11^{\circ} \text { Festival } \\
\text { Internacional de } \\
\text { Cine de Valdivia } \\
\text { (Chile) }\end{array}$ & & Best Actor \\
\hline 2003 & $\begin{array}{l}\text { Hable con } \\
\text { ella }\end{array}$ & Nominated & $\begin{array}{l}\text { Film Academy } \\
\text { Awards }\end{array}$ & Oscar & $\begin{array}{l}\text { Best Achievement } \\
\text { in Directing }\end{array}$ \\
\hline 2003 & & Winner & $\begin{array}{l}\text { Film Academy } \\
\text { Awards }\end{array}$ & Oscar & $\begin{array}{l}\text { Best Writing, } \\
\text { Screenplay } \\
\text { Written Directly } \\
\text { for the Screen }\end{array}$ \\
\hline
\end{tabular}




\begin{tabular}{|c|c|c|c|c|}
\hline 2003 & Winner & Golden Globes & Golden Globe & $\begin{array}{l}\text { Best Foreign } \\
\text { Language Film }\end{array}$ \\
\hline 2003 & Winner & BAFTA Awards & $\begin{array}{l}\text { BAFTA } \\
\text { Award }\end{array}$ & $\begin{array}{l}\text { Best Film not in } \\
\text { the English } \\
\text { Language }\end{array}$ \\
\hline 2003 & Winner & BAFTA Awards & \begin{tabular}{|l|} 
BAFTA \\
Award \\
\end{tabular} & $\begin{array}{l}\text { Best Screenplay } \\
\text { (Original) }\end{array}$ \\
\hline 2003 & Winner & Bodil Awards & Bodil Award & $\begin{array}{l}\text { Best Non- } \\
\text { American Film }\end{array}$ \\
\hline 2003 & Winner & $\begin{array}{l}\text { César Awards, } \\
\text { France }\end{array}$ & César & $\begin{array}{l}\text { Best European } \\
\text { Union Film }\end{array}$ \\
\hline 2003 & Winner & Czech Lions & Czech Lion & $\begin{array}{l}\text { Best Foreign } \\
\text { Language Film }\end{array}$ \\
\hline 2003 & Nominated & $\begin{array}{l}\text { David di Donatello } \\
\text { Awards }\end{array}$ & David & Best Foreign Film \\
\hline 2003 & Winner & $\begin{array}{l}\text { Golden Satellite } \\
\text { Awards }\end{array}$ & \begin{tabular}{|l|} 
Golden \\
Satellite \\
Award
\end{tabular} & $\begin{array}{l}\text { Best Screenplay, } \\
\text { Original } \\
\text { Best Motion } \\
\text { Picture }\end{array}$ \\
\hline 2003 & Nominated & $\begin{array}{l}\text { Golden Satellite } \\
\text { Awards }\end{array}$ & $\begin{array}{l}\text { Golden } \\
\text { Satellite } \\
\text { Award }\end{array}$ & Best Director \\
\hline 2003 & Nominated & Goya Awards & Goya & $\begin{array}{l}\text { Best Director } \\
\text { Best Screenplay } \\
\text { Original } \\
\text { Best Actor } \\
\text { Best Film } \\
\text { Best Sound } \\
\text { Best Special } \\
\text { Effects }\end{array}$ \\
\hline 2003 & Winner & Goya Awards & Goya & $\begin{array}{l}\text { Best Original } \\
\text { Music }\end{array}$ \\
\hline 2003 & Winner & $\begin{array}{l}\text { Syndicat Français } \\
\text { de la Critique de } \\
\text { Cinéma }\end{array}$ & Critics Award & Best Foreign Film \\
\hline 2003 & Nominated & $\begin{array}{l}\text { Chicago Film } \\
\text { Critics Association } \\
\text { Awards }\end{array}$ & CFCA Award & $\begin{array}{l}\text { Best Foreign } \\
\text { Language Film }\end{array}$ \\
\hline 2003 & Nominated & Guldbagge Awards & $\begin{array}{l}\text { Guldbagge } \\
\text { Award }\end{array}$ & Best Foreign Film \\
\hline 2003 & Nominated & $\begin{array}{l}\text { Online Film } \\
\text { Critics Society } \\
\text { Awards }\end{array}$ & OFCS Award & $\begin{array}{l}\text { Best Foreign } \\
\text { Language Film }\end{array}$ \\
\hline 2003 & Winner & $\begin{array}{l}\text { Vancouver Film } \\
\text { Critics Circle } \\
\end{array}$ & VFCC Award & Best Foreign Film \\
\hline
\end{tabular}




\begin{tabular}{|c|c|c|c|c|c|}
\hline 2002 & & Winner & Sergio Amedei & & Best Screenplay \\
\hline 2002 & & Winner & Nastro D'Argento & & \begin{tabular}{|l|} 
Best European \\
Film \\
\end{tabular} \\
\hline 2002 & & Winner & $\begin{array}{l}\text { Vellocino de Oro, } \\
\text { Russia }\end{array}$ & & Best Foreign Film \\
\hline 2002 & & Winner & $\begin{array}{l}\text { FIPRESCI, } \\
\text { Uruguay }\end{array}$ & $\begin{array}{l}\text { FIPRESCI } \\
\text { Award }\end{array}$ & $\begin{array}{l}\text { Best Film } \\
\text { Best Director }\end{array}$ \\
\hline 2002 & & Winner & $\begin{array}{l}\text { Trophées Le Film } \\
\text { Français }\end{array}$ & & $\begin{array}{l}\text { Best European } \\
\text { Film }\end{array}$ \\
\hline 2002 & & Nominated & $\begin{array}{l}\text { London Film } \\
\text { Critics Association } \\
\text { Awards }\end{array}$ & & $\begin{array}{l}\text { Best Foreign Film } \\
\text { Best Director }\end{array}$ \\
\hline 2002 & & Winner & $\begin{array}{l}\text { National Board of } \\
\text { Review }\end{array}$ & NBR Award & $\begin{array}{l}\text { Best Foreign } \\
\text { Language Film } \\
\end{array}$ \\
\hline 2002 & & Winner & Ciak D’Oro & & Best Foreign Film \\
\hline 2002 & & Winner & Bogey Awards & Bogey Award & \\
\hline 2002 & & Nominated & $\begin{array}{l}\text { British } \\
\text { Independent Film } \\
\text { Awards }\end{array}$ & $\begin{array}{l}\text { British } \\
\text { Independent } \\
\text { Film Award } \\
\end{array}$ & $\begin{array}{l}\text { Best Film Not in } \\
\text { the English } \\
\text { Language } \\
\end{array}$ \\
\hline 2002 & & Winner & $\begin{array}{l}\text { Los Angeles Film } \\
\text { Critics Association } \\
\text { Awards } \\
\end{array}$ & $\begin{array}{l}\text { LAFCA } \\
\text { Award }\end{array}$ & Best Director \\
\hline 2002 & & Winner & $\begin{array}{l}\text { European Film } \\
\text { Awards }\end{array}$ & $\begin{array}{l}\text { Audience } \\
\text { Award }\end{array}$ & Best Actor \\
\hline 2002 & & Winner & $\begin{array}{l}\text { European Film } \\
\text { Awards }\end{array}$ & $\begin{array}{l}\text { European } \\
\text { Film Award }\end{array}$ & Best Director \\
\hline 2002 & & Winner & $\begin{array}{l}\text { European Film } \\
\text { Awards }\end{array}$ & $\begin{array}{l}\text { European } \\
\text { Film Award }\end{array}$ & Best Film \\
\hline 2002 & & Winner & $\begin{array}{l}\text { European Film } \\
\text { Awards }\end{array}$ & $\begin{array}{l}\text { European } \\
\text { Film Award }\end{array}$ & Best Screenwriter \\
\hline 2002 & & Nominated & $\begin{array}{l}\text { European Film } \\
\text { Awards }\end{array}$ & $\begin{array}{l}\text { European } \\
\text { Film Award }\end{array}$ & Best Actor \\
\hline 2002 & & Nominated & $\begin{array}{l}\text { European Film } \\
\text { Awards }\end{array}$ & $\begin{array}{l}\text { European } \\
\text { Film Award }\end{array}$ & $\begin{array}{l}\text { Best } \\
\text { Cinematographer }\end{array}$ \\
\hline 2001 & & Winner & $\begin{array}{l}\text { European Film } \\
\text { Awards }\end{array}$ & $\begin{array}{l}\text { Audience } \\
\text { Award }\end{array}$ & Best Director \\
\hline 2000 & $\begin{array}{l}\text { Todo sobre } \\
\text { mi madre }\end{array}$ & Nominated & $\begin{array}{l}\text { Academy Awards, } \\
\text { Mexico }\end{array}$ & Silver Ariel & \begin{tabular}{|l|} 
Best \\
Iberoamerican \\
Film \\
\end{tabular} \\
\hline 2000 & & Winner & $\begin{array}{l}\text { Film Academy } \\
\text { Awards }\end{array}$ & Oscar & Best Foreign Film \\
\hline 2000 & & Winner & Golden Globes & Golden Globe & Best Foreign Film \\
\hline 2000 & & Nominated & $\begin{array}{l}\text { Argentinian Film } \\
\text { Critics Association } \\
\text { Awards }\end{array}$ & Silver Condor & Best Foreign Film \\
\hline
\end{tabular}




\begin{tabular}{|c|c|c|c|c|}
\hline 2000 & Winner & Bodil Awards & Bodil & $\begin{array}{l}\text { Best Non- } \\
\text { American Film }\end{array}$ \\
\hline 2000 & Winner & $\begin{array}{l}\text { British Academy } \\
\text { Awards }\end{array}$ & $\begin{array}{l}\text { BAFTA Film } \\
\text { Award }\end{array}$ & $\begin{array}{l}\text { Best Film Not in } \\
\text { the English } \\
\text { Language }\end{array}$ \\
\hline 2000 & Winner & $\begin{array}{l}\text { British Academy } \\
\text { Awards }\end{array}$ & $\begin{array}{l}\text { David Lean } \\
\text { Award }\end{array}$ & Best Direction \\
\hline 2000 & Nominated & $\begin{array}{l}\text { British Academy } \\
\text { Awards }\end{array}$ & $\begin{array}{l}\text { BAFTA Film } \\
\text { Award }\end{array}$ & \begin{tabular}{|l|} 
Best Screenplay- \\
Original
\end{tabular} \\
\hline 2000 & Winner & $\begin{array}{l}\text { Chicago Film } \\
\text { Critics Association } \\
\text { Award }\end{array}$ & CFCA Award & $\begin{array}{l}\text { Best Foreign } \\
\text { Language Film }\end{array}$ \\
\hline 2000 & Winner & $\begin{array}{l}\text { Cinema Brazil } \\
\text { Grand Prize }\end{array}$ & $\begin{array}{l}\text { Cinema Brazil } \\
\text { Grand Prize }\end{array}$ & Best Foreign Film \\
\hline 2000 & Nominated & $\begin{array}{l}\text { Czech Film and } \\
\text { Television } \\
\text { Academy Awards }\end{array}$ & Czech Lion & $\begin{array}{l}\text { Best Foreign } \\
\text { Language Film }\end{array}$ \\
\hline 2000 & Winner & $\begin{array}{l}\text { César Awards, } \\
\text { France }\end{array}$ & César & Best Foreign Film \\
\hline 2000 & Winner & $\begin{array}{l}\text { David di Donatello } \\
\text { Awards }\end{array}$ & David & Best Foreign Film \\
\hline 2000 & Winner & $\begin{array}{l}\text { German Film } \\
\text { Awards }\end{array}$ & $\begin{array}{l}\text { Best Foreign } \\
\text { Film }\end{array}$ & Best Foreign Film \\
\hline 2000 & Winner & Goya Awards & Goya & Best Director \\
\hline 2000 & Nominated & Goya Awards & Goya & \begin{tabular}{|l|} 
Best Original \\
Screenplay
\end{tabular} \\
\hline 2000 & Nominated & $\begin{array}{l}\text { Independent Spirit } \\
\text { Awards }\end{array}$ & \begin{tabular}{|l|} 
Independent \\
Spirit Award
\end{tabular} & Best Foreign Film \\
\hline 2000 & Winner & Robert Festival & Robert & $\begin{array}{l}\text { Best Non- } \\
\text { American Film }\end{array}$ \\
\hline 2000 & Nominated & $\begin{array}{l}\text { Australian Film } \\
\text { Institute }\end{array}$ & $\begin{array}{l}\text { Best Foreign } \\
\text { Film Award }\end{array}$ & Best Foreign Film \\
\hline 2000 & Winner & $\begin{array}{l}\text { British Academy } \\
\text { Awards }\end{array}$ & $\begin{array}{l}\text { David Lean } \\
\text { Award For } \\
\text { Direction }\end{array}$ & Best Direction \\
\hline 2000 & Winner & $\begin{array}{l}\text { Broadcast Film } \\
\text { Critics Association } \\
\text { Awards } \\
\end{array}$ & BFCA Award & $\begin{array}{l}\text { Best Foreign } \\
\text { Language Film }\end{array}$ \\
\hline 2000 & Winner & $\begin{array}{l}\text { Cinema Brazil } \\
\text { Grand Prize }\end{array}$ & $\begin{array}{l}\text { Cinema Brazil } \\
\text { Grand Prize }\end{array}$ & Best Foreign Film \\
\hline 2000 & Nominated & $\begin{array}{l}\text { GLAAD Media } \\
\text { Awards }\end{array}$ & $\begin{array}{l}\text { GLAAD } \\
\text { Media Award }\end{array}$ & $\begin{array}{l}\text { Outstanding Film } \\
\text { - Limited Release }\end{array}$ \\
\hline 2000 & Winner & Golden Globes & Golden Globe & $\begin{array}{l}\text { Best Foreign } \\
\text { Language Film }\end{array}$ \\
\hline
\end{tabular}




\begin{tabular}{|c|c|c|c|c|}
\hline 2000 & Winner & $\begin{array}{l}\text { Golden Satellite } \\
\text { Awards }\end{array}$ & $\begin{array}{l}\text { Golden } \\
\text { Satellite } \\
\text { Award } \\
\end{array}$ & $\begin{array}{l}\text { Best Motion } \\
\text { Picture, Foreign } \\
\text { Language }\end{array}$ \\
\hline 2000 & Nominated & $\begin{array}{l}\text { Golden Satellite } \\
\text { Awards }\end{array}$ & $\begin{array}{l}\text { Golden } \\
\text { Satellite } \\
\text { Award }\end{array}$ & $\begin{array}{l}\text { Best Performance } \\
\text { by an Actress in a } \\
\text { Motion Picture }\end{array}$ \\
\hline 2000 & Nominated & $\begin{array}{l}\text { Golden Satellite } \\
\text { Awards }\end{array}$ & \begin{tabular}{|l|} 
Golden \\
Satellite \\
Award \\
\end{tabular} & $\begin{array}{l}\text { Best Performance } \\
\text { by an Actress in a } \\
\text { Supporting Role } \\
\end{array}$ \\
\hline 2000 & Winner & Goya Awards & Goya & $\begin{array}{l}\text { Best Actress in a } \\
\text { Main Role }\end{array}$ \\
\hline 2000 & Winner & Goya Awards & Goya & $\begin{array}{l}\text { Best Production } \\
\text { Direction }\end{array}$ \\
\hline 2000 & Winner & Goya Awards & Goya & $\begin{array}{l}\text { Best Original } \\
\text { Music }\end{array}$ \\
\hline 2000 & Winner & Goya Awards & Goya & Best Editing \\
\hline 2000 & Winner & Goya Awards & Goya & Best Film \\
\hline 2000 & Winner & Goya Awards & Goya & Best Sound \\
\hline 2000 & Nominated & Goya Awards & Goya & $\begin{array}{l}\text { Best Actress in a } \\
\text { Supporting Role }\end{array}$ \\
\hline 2000 & Nominated & Goya Awards & Goya & Best New Actress \\
\hline 2000 & Nominated & Goya Awards & Goya & \begin{tabular}{|l|} 
Best Artistic \\
Direction \\
\end{tabular} \\
\hline 2000 & Nominated & Goya Awards & Goya & $\begin{array}{l}\text { Best Costume } \\
\text { Design }\end{array}$ \\
\hline 2000 & Nominated & Goya Awards & Goya & \begin{tabular}{|l|} 
Best \\
Cinematography
\end{tabular} \\
\hline 2000 & Nominated & Goya Awards & Goya & $\begin{array}{l}\text { Best Make-up and } \\
\text { Hairstyles }\end{array}$ \\
\hline 2000 & Winner & Guldbagge Awards & Guldbagge & Best Foreign Film \\
\hline 2000 & Nominated & $\begin{array}{l}\text { Online Film } \\
\text { Critics Society } \\
\text { Awards } \\
\end{array}$ & OFCS Award & $\begin{array}{l}\text { Best Foreign } \\
\text { Language Film }\end{array}$ \\
\hline 2000 & Winner & \begin{tabular}{|l|} 
Santa Fe Film \\
Critics Circle \\
Awards
\end{tabular} & $\begin{array}{l}\text { SFFCC } \\
\text { Award }\end{array}$ & $\begin{array}{l}\text { Best Foreign } \\
\text { Language Film }\end{array}$ \\
\hline 2000 & Winner & \begin{tabular}{|l|} 
Santa Fe Film \\
Critics Circle \\
Awards
\end{tabular} & $\begin{array}{l}\text { SFFCC } \\
\text { Award }\end{array}$ & $\begin{array}{l}\text { Best Supporting } \\
\text { Actress }\end{array}$ \\
\hline 1999 & Winner & $\begin{array}{l}\text { Cannes Film } \\
\text { Festival }\end{array}$ & Best Director & Best Director \\
\hline 1999 & Winner & \begin{tabular}{|l|} 
Cannes Film \\
Festival
\end{tabular} & $\begin{array}{l}\text { Prize of the } \\
\text { Ecumenical } \\
\text { Jury }\end{array}$ & Best Director \\
\hline
\end{tabular}




\begin{tabular}{|c|c|c|c|c|c|}
\hline 1999 & & Winner & $\begin{array}{l}\text { European Film } \\
\text { Awards }\end{array}$ & $\begin{array}{l}\text { Audience } \\
\text { Award }\end{array}$ & Best Director \\
\hline 1999 & & Winner & \begin{tabular}{|l} 
Fort Lauderdale \\
International Film \\
Festival
\end{tabular} & \begin{tabular}{|l|} 
People's \\
Choice Award
\end{tabular} & Best Director \\
\hline 1999 & & Winner & $\begin{array}{l}\text { New York Film } \\
\text { Critics Circle } \\
\text { Awards }\end{array}$ & $\begin{array}{l}\text { NYFCC } \\
\text { Award }\end{array}$ & Best Foreign Film \\
\hline 1999 & & Winner & \begin{tabular}{|l|} 
San Sebastián \\
International Film \\
Festival
\end{tabular} & $\begin{array}{l}\text { FIPRESCI } \\
\text { Film of the } \\
\text { Year }\end{array}$ & \\
\hline 1999 & & Winner & $\begin{array}{l}\text { Boston Society of } \\
\text { Film Critics } \\
\text { Awards }\end{array}$ & BSFC Award & $\begin{array}{l}\text { Best Foreign } \\
\text { Language Film }\end{array}$ \\
\hline 1999 & & Winner & \begin{tabular}{|l} 
British \\
Independent Film \\
Awards
\end{tabular} & $\begin{array}{l}\text { British } \\
\text { Independent } \\
\text { Film Award }\end{array}$ & Best Foreign Film \\
\hline 1999 & & Nominated & Camerimage & Golden Frog & \\
\hline 1999 & & Nominated & \begin{tabular}{|l|} 
Cannes Film \\
Festival \\
\end{tabular} & Golden Palm & \\
\hline 1999 & & Winner & $\begin{array}{l}\text { European Film } \\
\text { Awards }\end{array}$ & $\begin{array}{l}\text { European } \\
\text { Film Award }\end{array}$ & Best Actress \\
\hline 1999 & & Winner & $\begin{array}{l}\text { European Film } \\
\text { Awards }\end{array}$ & $\begin{array}{l}\text { European } \\
\text { Film Award }\end{array}$ & Best Film \\
\hline 1999 & & Winner & $\begin{array}{l}\text { Los Angeles Film } \\
\text { Critics Association } \\
\text { Awards }\end{array}$ & $\begin{array}{l}\text { LAFCA } \\
\text { Award }\end{array}$ & $\begin{array}{l}\text { Best Foreign } \\
\text { Language Film }\end{array}$ \\
\hline 1999 & & Winner & \begin{tabular}{|l|} 
National Board of \\
Review, USA \\
\end{tabular} & NBR Award & $\begin{array}{l}\text { Best Foreign } \\
\text { Language Film } \\
\end{array}$ \\
\hline 1999 & $\begin{array}{l}\text { Carne } \\
\text { trémula }\end{array}$ & Nominated & $\begin{array}{l}\text { British Academy } \\
\text { Awards }\end{array}$ & $\begin{array}{l}\text { BAFTA Film } \\
\text { Award }\end{array}$ & $\begin{array}{l}\text { Best Film not in } \\
\text { the English } \\
\text { Language }\end{array}$ \\
\hline 1998 & & Nominated & $\begin{array}{l}\text { Golden Satellite } \\
\text { Awards }\end{array}$ & \begin{tabular}{|l|} 
Golden \\
Satellite \\
Award
\end{tabular} & $\begin{array}{l}\text { Best Motion } \\
\text { Picture Foreign } \\
\text { Language }\end{array}$ \\
\hline 1998 & & Winner & \begin{tabular}{|l} 
Italian National \\
Syndicate of Film \\
Journalists \\
\end{tabular} & Silver Ribbon & $\begin{array}{l}\text { Best Director- } \\
\text { Foreign Film }\end{array}$ \\
\hline 1998 & & Winner & $\begin{array}{l}\text { Popcorn Film } \\
\text { Festival }\end{array}$ & $\begin{array}{l}\text { Audience } \\
\text { Award }\end{array}$ & \\
\hline 1998 & & Nominated & \begin{tabular}{|l|} 
Sao Paulo \\
International Film \\
Festival \\
\end{tabular} & $\begin{array}{l}\text { Audience } \\
\text { Award }\end{array}$ & Best Feature \\
\hline
\end{tabular}




\begin{tabular}{|c|c|c|c|c|c|}
\hline 1998 & & Nominated & \begin{tabular}{|l} 
British \\
Independent Film \\
Awards
\end{tabular} & \begin{tabular}{|l} 
British \\
Independent \\
Film Award
\end{tabular} & \begin{tabular}{|l|} 
Best Foreign \\
Independent Film
\end{tabular} \\
\hline 1998 & & Nominated & $\begin{array}{l}\text { European Film } \\
\text { Awards }\end{array}$ & \begin{tabular}{|l} 
European \\
Film Award
\end{tabular} & Best Actor \\
\hline 1998 & & Nominated & $\begin{array}{l}\text { European Film } \\
\text { Awards }\end{array}$ & \begin{tabular}{|l} 
European \\
Film Award
\end{tabular} & Best Film \\
\hline 1998 & & Winner & Goya Awards & Goya & $\begin{array}{l}\text { Best Supporting } \\
\text { Actor }\end{array}$ \\
\hline 1998 & & Nominated & Goya Awards & Goya & Best Actor \\
\hline 1998 & & Nominated & Goya Awards & Goya & $\begin{array}{l}\text { Best Supporting } \\
\text { Actress }\end{array}$ \\
\hline 1998 & & Winner & \begin{tabular}{|l|} 
Italian National \\
Syndicate of Film \\
Journalists \\
\end{tabular} & Silver Ribbon & Best Actress \\
\hline 1996 & $\begin{array}{l}\text { La flor de } \\
\text { mi secreto }\end{array}$ & Nominated & \begin{tabular}{|l} 
Karlovy Vary \\
International Film \\
Festival
\end{tabular} & Crystal Globe & $\begin{array}{l}\text { Best Foreign } \\
\text { Actor }\end{array}$ \\
\hline 1996 & & Winner & $\begin{array}{l}\text { Karlovy Vary } \\
\text { International Film } \\
\text { Festival }\end{array}$ & Best Actress & $\begin{array}{l}\text { Best Foreign } \\
\text { Actor }\end{array}$ \\
\hline 1996 & & Nominated & Goya Awards & Goya & $\begin{array}{l}\text { Best Supporting } \\
\text { Actress }\end{array}$ \\
\hline 1996 & & Nominated & Goya Awards & Goya & Best Director \\
\hline 1996 & & Nominated & Goya Awards & Goya & Best Actress \\
\hline 1996 & & Nominated & Goya Awards & Goya & $\begin{array}{l}\text { Best Artistic } \\
\text { Direction }\end{array}$ \\
\hline 1996 & & Nominated & Goya Awards & Goya & $\begin{array}{l}\text { Best Make-up and } \\
\text { Hairstyles } \\
\end{array}$ \\
\hline 1996 & & Nominated & Goya Awards & Goya & Best Sound \\
\hline 1993 & \begin{tabular}{|l} 
Tacones \\
lejanos
\end{tabular} & Winner & $\begin{array}{l}\text { César Awards, } \\
\text { France }\end{array}$ & César & Best Foreign Film \\
\hline 1992 & & Winner & \begin{tabular}{|l|} 
Gramado Film \\
Festival
\end{tabular} & Golden Kikito & Best Director \\
\hline 1992 & & Nominated & $\begin{array}{l}\text { Gramado Film } \\
\text { Festival }\end{array}$ & Golden Kikito & \begin{tabular}{|l} 
Best Ibero- \\
American Film \\
\end{tabular} \\
\hline 1991 & ¡Átame! & Nominated & Goya Awards & Goya & $\begin{array}{l}\text { Best Original } \\
\text { Screenplay }\end{array}$ \\
\hline 1991 & & Nominated & Goya Awards & Goya & Best Director \\
\hline 1991 & & Nominated & $\begin{array}{l}\text { Berlin } \\
\text { International Film } \\
\text { Festival }\end{array}$ & $\begin{array}{l}\text { Golden Berlin } \\
\text { Bear }\end{array}$ & \\
\hline 1991 & & Nominated & $\begin{array}{l}\text { César Awards, } \\
\text { France }\end{array}$ & César & Best Foreign Film \\
\hline
\end{tabular}




\begin{tabular}{|c|c|c|c|c|c|}
\hline 1989 & $\begin{array}{l}\text { Mujeres al } \\
\text { borde de } \\
\text { un ataque } \\
\text { de nervios }\end{array}$ & Nominated & $\begin{array}{l}\text { British Academy } \\
\text { Awards }\end{array}$ & $\begin{array}{l}\text { BAFTA Film } \\
\text { Award }\end{array}$ & $\begin{array}{l}\text { Best Film Not in } \\
\text { the English } \\
\text { Language }\end{array}$ \\
\hline 1989 & & Winner & $\begin{array}{l}\text { David di Donatello } \\
\text { Awards }\end{array}$ & David & $\begin{array}{l}\text { Best Director- } \\
\text { Foreign Film }\end{array}$ \\
\hline 1989 & & Winner & Goya Awards & Goya & $\begin{array}{l}\text { Best Original } \\
\text { Screenplay }\end{array}$ \\
\hline 1989 & & Nominated & Goya Awards & Goya & Best Director \\
\hline 1989 & & Winner & $\begin{array}{l}\text { Italian National } \\
\text { Syndicate of Film } \\
\text { Journalists }\end{array}$ & Silver Ribbon & $\begin{array}{l}\text { Best Director- } \\
\text { Foreign Film }\end{array}$ \\
\hline 1989 & & Winner & $\begin{array}{l}\text { National Society } \\
\text { of Film Critics } \\
\text { Awards, USA }\end{array}$ & $\begin{array}{l}\text { Special } \\
\text { Award }\end{array}$ & \\
\hline 1989 & & Nominated & $\begin{array}{l}\text { Venice Film } \\
\text { Festival }\end{array}$ & Golden Osella & Best Screenplay \\
\hline 1988 & & Winner & \begin{tabular}{|l|} 
Toronto \\
International Film \\
Festival \\
\end{tabular} & $\begin{array}{l}\text { People's } \\
\text { Choice Award }\end{array}$ & \\
\hline 1988 & & Winner & $\begin{array}{l}\text { European Film } \\
\text { Awards }\end{array}$ & $\begin{array}{l}\text { European } \\
\text { Film Award }\end{array}$ & Best Young Film \\
\hline 1988 & $\begin{array}{l}\text { La ley del } \\
\text { deseo }\end{array}$ & Nominated & \begin{tabular}{|l} 
Bogota Film \\
Festival
\end{tabular} & $\begin{array}{l}\text { Golden } \\
\text { Precolumbian } \\
\text { Circle }\end{array}$ & Best Film \\
\hline 1988 & & Winner & \begin{tabular}{|l|} 
Bogota Film \\
Festival
\end{tabular} & $\begin{array}{l}\text { Golden } \\
\text { Precolumbian } \\
\text { Circle }\end{array}$ & Best Director \\
\hline 1988 & & Winner & $\begin{array}{l}\text { Bogota Film } \\
\text { Festival }\end{array}$ & $\begin{array}{l}\text { Golden } \\
\text { Precolumbian } \\
\text { Circle }\end{array}$ & Best Screenplay \\
\hline 1987 & & Winner & $\begin{array}{l}\text { Berlin } \\
\text { International Film } \\
\text { Festival } \\
\end{array}$ & Teddy & Best Feature Film \\
\hline 1987 & & Winner & $\begin{array}{l}\text { San Francisco } \\
\text { International } \\
\text { Lesbian \& Gay } \\
\text { Film Festival } \\
\end{array}$ & $\begin{array}{l}\text { Audience } \\
\text { Award }\end{array}$ & Best Feature \\
\hline 1988 & Matador & Nominated & $\begin{array}{l}\text { Bogota Film } \\
\text { Festival }\end{array}$ & \begin{tabular}{|l|} 
Golden \\
Precolumbian \\
Circle \\
\end{tabular} & Best Film \\
\hline 1988 & & Winner & $\begin{array}{l}\text { National Society } \\
\text { of Film Critics } \\
\text { Awards, USA }\end{array}$ & $\begin{array}{l}\text { Special } \\
\text { Award }\end{array}$ & \\
\hline
\end{tabular}




\begin{tabular}{|l|l|l|l|l|l|}
\hline 1987 & Winner & Fantasporto & $\begin{array}{l}\text { International } \\
\text { Fantasy Film } \\
\text { Award }\end{array}$ & Best Director \\
\hline 1987 & & Nominated & Fantasporto & $\begin{array}{l}\text { International } \\
\text { Fantasy Film } \\
\text { Award }\end{array}$ & Best Film \\
\hline 1986 & & Winner & Fantasporto & $\begin{array}{l}\text { International } \\
\text { Fantasy Film } \\
\text { Special Jury } \\
\text { Award }\end{array}$ & \\
\hline
\end{tabular}

\section{The Translation of Almodóvar's Films}

\subsection{Methodological Aspects}

\subsubsection{Corpus}

As already mentioned, Almodóvar has achieved great popularity in the US film market. So far, his films have been great box office success all over the US. Of the sixteen films he has directed, I have decided to include ten in the corpus of this study. The films analyzed here are in the original Spanish with English subtitles:

5. Laberinto de pasiones [Labyrinth of Passions] (1982). A parody of Spanish society of the 1980s obsessed with gossip magazines.

6. ¿Qué he hecho yo para merecer esto? [What Have I Done to Deserve This?] (1984). A tough drama about a low-class family and its economic and family problems. 
7. Matador [Matador] (1985). A dramatic thriller dealing with the obsessions of two people.

8. La ley del deseo [Law of Desire] (1987). A drama about the homosexual world.

9. Mujeres al borde de un ataque de nervios [Women on the Verge of a Nervous Breakdown] (1988). A desperate woman and her constant struggle to talk to the man who has abandoned her.

10. ¡Átame! [Tie me up! Tie me down!] (1990). A love story camouflaged as an obsession.

11. Tacones lejanos [High Heels] (1991). A thriller about the difficult relationship between a mother and her only daughter.

12. Kika $[K i k a]$ (1993). The life of a beautician victimized by men.

13. Carne trémula [Live Flesh] (1997). A shooting that leads to a beautiful love story.

14. Todo sobre mi madre [All About My Mother] (1999). The drama of a mother who, after losing her son, goes to Barcelona in search of her transsexual ex-husband.

\subsubsection{Delimitation of the Object of Analysis}

The dialogues of the ten films analyzed here have provided me with numerous and specific examples for my analysis of subtitles. I have decided not to include Hable con ella, La mala educación, or Volver since these films were released after I 
finished my study. Ten films constitute a substantial proportion of Almodóvar's work, and the examples taken from them are representative samples of the language and humor involved.

I have also decided not to include a macrostructural analysis, as the current study does not focus on stills, shots, scenes, and such an undertaking would exceed the limits of this dissertation. Nevertheless, I do consider such a macrostructural aspect to be part of my future research.

\subsubsection{Model of Analysis to be used in Almodóvar's} Films

There are several models of analysis of audiovisual translation proposed by scholars from which I have elaborated my own model, which I now propose to outline having studied the different models presented by Ballester (2001a), Gutiérrez (2000) and Díaz Cintas (1998).

\section{E) Preliminary Aspects}

All the films by Almodóvar are presented to US audiences with their corresponding titles in English ${ }^{27}$ : Labyrinth of Passions, What Have I Done to Deserve This?, Law of Desire, Women on the Verge of a Nervous Breakdown, Tie Me Up! Tie Me Down!, High Heels, Kika, Live Flesh, and All About My Mother. The examples in this analysis will only display the SL title, as well as the year when they were released in Spain.

\footnotetext{
${ }^{27}$ It will be seen that the corresponding titles in English are literal translations of the Spanish titles - though Matador is kept in English, and so is Kika.
} 
Just two of these films display the name of the translator: Laberinto de pasiones translated and adapted by Deidre MacCloskey, and ¿Qué he hecho yo para merecer esto? by Mathilde Grange. The other films do not reveal the name of the translator or group of translators. I remember watching a news report at the time Todo sobre mi madre was released; it stated that Laser Films was the company in charge of the subtitles. The fact that most of Almodóvar's films do not display the names of the translators in their credits has "a negative impact on the social recognition of subtitlers which is most patent in the lack of copyright for their work" (Díaz Cintas 2007: 40).

Before examining the English of the translations, it is necessary to formulate the respective positions of both cultures, the Spanish and the North American ${ }^{28}$, on the international scene. The US position nowadays is one of undisputed supremacy. After the disappearance of the Soviet Union, the US reached the superiority it had always longed for. Yet its economy is currently suffering increasing difficulty, due to the wars with Afghanistan and Iraq. On the other hand, the increasing recognition of Spanish as one of the most widely spoken languages in the world is progressively changing the international position of Spain. Due to the growing Hispanic population in the US, Spanish has become the most important language in the US after English. The Spanish speaking population in the US is now the biggest minority (around 34\%). Everything related to "lo latino", and obviously to Spain, is considered attractive in the US.

From 2000 to 2004 the relationship between Spain and the US could be defined as excellent, mainly due to the communication between George W. Bush and the former Spanish President José María Aznar.

\footnotetext{
${ }^{28}$ The films analyzed are the ones commercialised in the US, therefore from now on, the US culture will be the target one.
} 
Spain has always maintained good relations with the US, which were reinforced by Spain's former government's support to the war with Iraq. Indeed, anything connected with the Spanish speaking world is of significant concern to the US government. Today's new Spanish government - the PSOE - will undoubtedly change the former coalition since they oppose Spanish participation in the war in Iraq.

It is worth mentioning that just one of the films analyzed here has been adapted from a novel ${ }^{29}$; the rest of the films are based on original scripts and screenplays.

Most of Almodóvar's films belong to the genre of drama sometimes mixed with brushstrokes of comedy. Laberinto de pasiones could be defined as a witty parody of some aspects of Spanish society in the 1980s. ¿Qué he hecho yo para merecer esto?, La ley del deseo, ¡Átame!, and Carne trémula are dramas, with ¿Qué he hecho yo para merecer esto? as his toughest film so far. The plot of Todo sobre mi madre is shocking, while there are many humorous moments generated by some of the characters. Mujeres starts as a melodrama but shifts into comedy as the story develops. Kika is also a facetious movie, and Tacones lejanos belongs to the genre of the thriller. These various genres definitely exist in American cinema. However, Almodóvar used these categories with great originality ${ }^{30}$.

As for censorship, I presumed that the analysis of the dialogues and subtitles of the ten films included in this study would lead to significant conclusions regarding the appropriateness of the translation, or whether there had been omissions, or a softening of certain

\footnotetext{
${ }^{29}$ Carne trémula (1997) is based on the novel by the British writer Ruth Rendell Live Flesh, whose title is kept in the English version.

${ }^{30}$ Further research on genre is examined in section IV which includes results to the surveys of students of Spanish.
} 
expressions. What I do is to analyze whether the audiovisual translators have followed certain norms existing in the target culture.

\section{F) Microstructure}

The analysis of the microstructure deals with those fragments and instances that present relevant characteristics of Almodóvar's work, and, at the same time, it determines the process followed by the communicative translation from the $\mathrm{SL}$ into the TL. In my analysis, I follow some sections of Allinson's proposal (2001) and also add others. Due to their relevance in the study, the film dialogues have been divided into linguistic units that meet one or more of the following descriptions:

8. Insulting and scatological expressions

9. Expressions concerning sexual and bodily functions

10. Expressions related to rural life

11. Swearing

12. Slang

13. Accent

14. Culture bound references

- Food references

i. Vocabulary related to drugs

j. Wordplay and expressions

k. Errors in the subtitles of the films

The methodology in the following analysis is based on the assumption that equivalence is a dynamic concept, in contrast to previous theories where equivalence was considered to be a static and normative concept. In analyzing the films, I have occasionally found that some subtitles do not achieve the equivalent effect. 
Having said this, I am not sure whether there is a really correct version. Rather, out of the possible acceptable versions in the $T L$, some of the subtitles seem to be less good than others.

\title{
3.2. Application of the Model of Analysis
}

\author{
For anyone familiar with \\ both Spanish and English, a \\ random check on the \\ subtitles in any of the films \\ reveals how much is lost in \\ translation, how difficult is \\ to find equivalents in \\ English for the many colour \\ phrases which abound in \\ Almodóvar's films. \\ Mark Allinson, A Spanish \\ Labyrinth: The Films of \\ Pedro Almodóvar.
}

The film dialogues of Almodóvar are full of expletives and expressions which originally contained sexual or sexist connotations, but which have acquired a neutral status due to the frequency of their usage by most Spanish speakers:

In every language and culture there exist words and expressions judged, usually subjectively, as bad language. Vulgar and colloquial expressions, incorrect or inaccurate uses of lexis, grammar and 
pronunciation, malapropisms, sloppy speech, slang, jargon and swearing are just some examples of this universal phenomenon. [...] Bad language is assumed to be dangerous and certainly something to be avoided. (Fernández Dobao 2006: 222)

Swearing and everything related to bad language used to be avoided in the media; however, with the passing of time they have been appearing within the domains of public language as something more and more natural:

\footnotetext{
Nowadays, we are used to the use and sometimes even abuse of swear words not only in the cinema [...]. Writers and directors introduce in their works a much more informal and colloquial language, on behalf of naturalness and realism. (Fernández Dobao 2006: 223)
}

One of the difficulties in translating such words is "to determine exactly where they range on the scale of rudeness", and the only way to deal with such expression is "to find the idiomatic equivalent in the subtitler's own language" (Ivarsson \& Carroll 1998: 126-127). So when it comes to the translation of many swear words from Spanish into English, cultural differences and the lack of exact equivalents raise translatological problems.

\section{- Insulting and Scatological Expressions}

One of the most frequently occurring expressions in the film dialogues is the Spanish insult "hijo/a de puta", whose closest English equivalents would be "son of a bitch". In La ley del deseo, Tina gets really mad at the journalists who still focus on her sex change: 


\begin{tabular}{|l|l|l|}
\hline FILM AND YEAR & SOURCE TEXT & TARGET TEXT \\
\hline $\begin{array}{l}\text { La ley del deseo } \\
\text { (1987) }\end{array}$ & $\begin{array}{l}\text {-iHijos de perra! } \\
\text { (Tina) }\end{array}$ & Sons of bitches! \\
\hline
\end{tabular}

In Matador Diego finds out that one of his students has raped his girlfriend

\begin{tabular}{|l|l|l|}
\hline FILM AND YEAR & SOURCE TEXT & TARGET TEXT \\
\hline Matador (1986) & $\begin{array}{l}-¿ \text { Qué quiere que le diga? } \\
\text { Que es un hijo de perra } \\
\text { (Diego) }\end{array}$ & That he’s a s.o.b. \\
\hline
\end{tabular}

In this example, probably due to space constraints, the translator has decided to abbreviate the insult. In ;Átame!, the drug dealer, played by Rosy de Palma, shows her anger at Ricky when he robs her while making a deal:

\begin{tabular}{|l|l|l|}
\hline FILM AND YEAR & SOURCE TEXT & TARGET TEXT \\
\hline ¡Átame! (1990) & $\begin{array}{l}\text {-¡Hijo de perra! (Rosy } \\
\text { de Palma) }\end{array}$ & Son-of-a-bitch! \\
\hline
\end{tabular}

In Tacones lejanos one of the prisoners talks about a guy who betrayed some of his friends by working for the police. Her anger can be perceived in the way she talks about him:

\begin{tabular}{|l|l|l|}
\hline FILM AND YEAR & SOURCE TEXT & TARGET TEXT \\
\hline $\begin{array}{l}\text { Tacones lejanos } \\
(1991)\end{array}$ & $\begin{array}{l}\text {-No me digas que eres } \\
\text { amiga de ese hijo puta } \\
\text { (Prisoner) }\end{array}$ & What a son-of-a-bitch! \\
\hline
\end{tabular}


\begin{tabular}{|l|l|l|}
\hline & & \\
\hline
\end{tabular}

In Carne trémula David insults with emphasis when he realizes that the man who shot him has not only been released, but is working at the nursery owned by his wife:

\begin{tabular}{|l|l|l|}
\hline FILM AND YEAR & SOURCE TEXT & TARGET TEXT \\
\hline $\begin{array}{l}\text { Carne trémula } \\
\text { (1997) }\end{array}$ & $\begin{array}{l}\text { iQue hijo de la gran } \\
\text { puta! (David) }\end{array}$ & $\begin{array}{l}\text { Fucking son of a } \\
\text { bitch! }\end{array}$ \\
\hline
\end{tabular}

Here the translator has resorted to using the word "fucking" together with the main insult, while the ST displays the adjective "gran" which simply means "big". Yet, the target version insults the recipient himself, not the mother, by placing “fucking” before "son”. Similarly, La Agrado in Todo sobre mi madre utters the same insult twice when one of her "clients" tries to hurt her. In addition, her high pitched voice and her Andalusian accent make the insult sound funny in Spanish, while the comic aspect of the original is lost in the subtitle:

\begin{tabular}{|l|l|l|}
\hline FILM AND YEAR & SOURCE TEXT & TARGET TEXT \\
\hline $\begin{array}{l}\text { Todo sobre } m i \\
\text { madre (1999) }\end{array}$ & $-¡$ Hijo puta! (Agrado) & Son of a bitch! \\
\hline
\end{tabular}

"Bastard(s)" is another word, widely used throughout the

films, that does not nearly reflect the anger of the character, as it is less insulting a term than "son of a bitch": 


\begin{tabular}{|c|c|c|}
\hline FILM AND YEAR & SOURCE TEXT & TARGET TEXT \\
\hline Matador (1986) & -¡Hijos de puta! (Eva) & Bastards! \\
\hline ¡Átame! (1986) & -¡Hijo puta! (Marina) & Bastard! \\
\hline $\begin{array}{l}\text { Carne trémula } \\
\text { (1997) }\end{array}$ & -¡Jo puta! (Doña Centro) & Bastard! \\
\hline $\begin{array}{l}\text { Carne trémula } \\
\text { (1997) }\end{array}$ & -¡Hijo puta! (Víctor) & Bastard! \\
\hline
\end{tabular}

In Carne trémula "hijo de puta" can be found several times in different contexts with slight variations. However, the lack of adequacy is noticeable in two examples, both uttered by David:

\begin{tabular}{|l|l|l|}
\hline FILM AND YEAR & SOURCE TEXT & TARGET TEXT \\
\hline $\begin{array}{l}\text { Carne trémula } \\
(1997)\end{array}$ & $-¡$ iHijo de la gran puta! & Bastard! \\
\hline $\begin{array}{l}\text { Carne trémula } \\
(1997)\end{array}$ & $\begin{array}{l}\text {-¡Hijo puta! No sabes lo } \\
\text { que dices. }\end{array}$ & You stupid bastard! \\
\hline
\end{tabular}

In the first of these two examples the emphasis on the insult, expressed by the adjective "gran" in the ST, is not reflected in the TT. In the second one, the insult is not intensified by any adjective in the ST, but the TT has added the adjective "stupid", intensifying the insult. These two translations display inconsistencies, as the intensification of the insult in the TT should have been made in the first example, and not in the second one. 
"Bitch" appears as the English rendering of "hijo/a de puta" or "hijo/a de perra" on several occasions. Yet, it does not produce the equivalent effect since it does not offend the "mother" of the addressee in the way the source insult does:

\begin{tabular}{|l|l|l|}
\hline FILM AND YEAR & SOURCE TEXT & TARGET TEXT \\
\hline $\begin{array}{l}\text { Mujeres al borde } \\
\text { de un ataque de } \\
\text { nervios (1988) }\end{array}$ & $\begin{array}{l}\text {-Y usted tampoco es } \\
\text { una abogada justed es } \\
\text { una hija de perra! } \\
\text { (Pepa) }\end{array}$ & $\begin{array}{l}\text { You're certainly } \\
\text { no lawyer, you bitch! }\end{array}$ \\
\hline iAtame! (1990) & $\begin{array}{l}\text {-¡Hija de puta! } \\
\text { (Ricky) }\end{array}$ & Bitch! \\
\hline $\begin{array}{l}\text { Todo sobre mi } \\
\text { madre (1999) }\end{array}$ & $\begin{array}{l}\text {-¿Qué pasa? Si lo } \\
\text { tenías todo planeado } \\
\text { ¿eh? ¡hija puta!.. } \\
\text { (Nina) }\end{array}$ & $\begin{array}{l}\text { What’s up!// } \\
\text { You planned it all, bitch! }\end{array}$ \\
\hline
\end{tabular}

The force of the ST in these examples is stronger and more vulgar than the one in the TTs.

Depending on the context, there are also some examples in which the characters use this derogatory term in a friendly and funny way. In this case it has a neutral status in Spanish, as it is possible to call someone with whom you have a special relationship and complicity "hijo/a puta". Of course, this does not mean that the expression is not rude; it definitely is. But some people do use it in jest or to praise somebody for being lucky, for instance. The same could be said of the target culture: ostensibly insulting expressions can be used when addressing a close friend in a well-meaning and affectionate way. Indeed, in Todo sobre mi madre, it is mostly the character of Agrado who utters well meaning expressions. The TT displays again the word "bitch" which achieves the equivalent effect of the ST: 


\begin{tabular}{|l|l|l|}
\hline FILM AND YEAR & SOURCE TEXT & TARGET TEXT \\
\hline $\begin{array}{l}\text { Todo sobre } m i \\
\text { madre (1999) }\end{array}$ & $\begin{array}{l}\text {-iCreí que te } \\
\text { habías muerto, } \\
\text { hija puta! } \\
\text { (Agrado) }\end{array}$ & $\begin{array}{l}\text { I thought you were dead, } \\
\text { bitch! }\end{array}$ \\
\hline & $\begin{array}{l}\text {-...aunque solo } \\
\text { sea 'pa' } \\
\text { hincharme de } \\
\text { llorar, hija puta } \\
\text { (Agrado) }\end{array}$ & to cry my eyes out, bitch! \\
\hline
\end{tabular}

In the course of the film, the spectator of Todo sobre mi madre is witness to the special relationship between Manuela and Agrado, so that the 'particular' use Agrado makes of this insult to address her friend Manuela is easily understood.

In some of the films there are examples in which there is a questionable intensification of the insult in the TT:

\begin{tabular}{|l|l|l|}
\hline FILM AND YEAR & SOURCE TEXT & TARGET TEXT \\
\hline Matador (1986) & $\begin{array}{l}\text {-¿No irás a reunirte con } \\
\text { él, hija de la gran } \\
\text { puta? (Eva) }\end{array}$ & $\begin{array}{l}\text { You wouldn't go to him, } \\
\text { You fucking whore! }\end{array}$ \\
\hline $\begin{array}{l}\text { Tacones lejanos } \\
\text { (1991) }\end{array}$ & $\begin{array}{l}\text {-¡Te voy a matar hija } \\
\text { de puta! (Chon) }\end{array}$ & You goddamn bitch! \\
\hline $\begin{array}{l}\text { Todo sobre mi } \\
\text { madre (1999) }\end{array}$ & $\begin{array}{l}\text {-¡Hija de la gran puta! } \\
\text { (Manuela) }\end{array}$ & That lousy fucking bitch! \\
\hline
\end{tabular}

The STs do not display any gradations in the insult, merely the addition of the adjective "gran" in the third one. Indeed, they show certain homogeneity. The TTs, on the other hand, show different translations of 
the expression ("whore", "bitch") as well as additions ("fucking", "goddamn" and "lousy fucking"), which may be regarded as excessive.

Conversely, there are examples in which the insult is omitted in the TT. As mentioned in the introduction, dialogues that have been omitted and do not appear on the screen are represented by the symbol "...:...:...:.":

\begin{tabular}{|l|l|l|}
\hline FILM AND YEAR & SOURCE TEXT & TARGET TEXT \\
\hline $\begin{array}{l}\text { Mujeres al borde } \\
\text { de un ataque de } \\
\text { nervios (1988) }\end{array}$ & - ¡Hija de puta! (Ana) & $: \ldots: \ldots: \ldots::$ \\
\hline $\begin{array}{l}\text { Carne trémula } \\
\text { (1997) }\end{array}$ & - i...hijo de puta! (David) & $\ldots: \ldots: \ldots:::$ \\
\hline $\begin{array}{l}\text { Carne trémula } \\
\text { (1997) }\end{array}$ & - -iHijo puta! (David) & $: \ldots: \ldots: \ldots::$ \\
\hline
\end{tabular}

It would be hazardous to try to give a reason for this absence of translation. Perhaps if the insult is not uttered loudly, the translator ignores it in order to use the allotted space for more relevant information. Or perhaps if such insults are repetitions, the translator opts to omit them, or as in Tacones lejanos, in order to neutralize them:

\begin{tabular}{|l|l|l|}
\hline $\begin{array}{l}\text { FILM AND } \\
\text { YEAR }\end{array}$ & SOURCE TEXT & TARGET TEXT \\
\hline $\begin{array}{l}\text { Tacones lejanos } \\
(1991)\end{array}$ & $\begin{array}{l}\text {-¡No lo llames hijo puta! } \\
\text { (Paula) }\end{array}$ & Don’t call him that! \\
\hline
\end{tabular}


There are many examples of other insults addressed to women such as "puta", "putón", "zorra", and their translation is different too. "Puta" translated into English is "slut" or "whore", which also keeps the derogatory meaning.

\begin{tabular}{|l|l|l|}
\hline FILM AND YEAR & SOURCE TEXT & TARGET TEXT \\
\hline iAtame! (1990) & $\begin{array}{l}\text {-iMe has estado dando } \\
\text { largas, puta! (Ricky) }\end{array}$ & $\begin{array}{l}\text { You tricked me, you } \\
\text { whore! }\end{array}$ \\
\hline
\end{tabular}

In this example, Ricky is really mad at Marina because he is falling in love with her and she is not. Therefore the translator has intensified the aggressive behavior of Ricky -who does not hesitate to hurt her - with the insertion of the personal pronoun "you".

\begin{tabular}{|l|l|l|}
\hline$\underline{\text { FILM }} \underline{\text { YEAR }}$ & $\underline{\text { SOURCE TEXT }}$ & $\underline{\text { TARGET TEXT }}$ \\
\hline $\begin{array}{l}\text { Todo sobre } m i \\
\text { madre (1999) }\end{array}$ & $\begin{array}{l}\text {-Mejor, porque estas } \\
\text { monjas sólo ayudan a } \\
\text { putas y travestís. O sea } \\
\text { que... (Agrado) }\end{array}$ & $\begin{array}{l}\text { All the better. These } \\
\text { nuns only / } \\
\text { help whores and } \\
\text { transvestites. }\end{array}$ \\
\hline & $\begin{array}{l}\text {-Y si tuviéramos poca } \\
\text { competencia con las } \\
\text { putas... (Agrado) }\end{array}$ & $\begin{array}{l}\text { The whores were bad } \\
\text { enough, ... }\end{array}$ \\
\hline & $\begin{array}{l}\text {-Luego dejé el camión y } \\
\text { me hice puta (Agrado) }\end{array}$ & $\begin{array}{l}\text { Then I gave up the } \\
\text { truck / } \\
\text { and became a whore. }\end{array}$ \\
\hline
\end{tabular}

These examples from Todo sobre mi madre are all uttered by Agrado, who works as a prostitute. She refers to herself as being a "whore" in a way that is not derogatory at all, since it is what she does for a living. She also addresses her fellow colleagues as “whores”. Agrado's Andalusian 
accent, together with her personality and her way of speaking, produce continuous laughter in a Spanish-speaking audience every time she opens her mouth. Perhaps it might have been more courteous for her to address herself and her buddies as "prostitutas" ("prostitutes"), but the insertion of a rude word such as "puta" does nothing to distress the audience, and so the humor is kept. What is lost in the translation is the comical aspect of the accent and the natural way in which Agrado talks about her colleagues.

Other examples with "puta" can be found in the same film. They are uttered by Rosa's mother who belongs to high society, lives a respectable life, is the mother of a nun, and clearly shows her disrespect towards women who work as prostitutes. So when her daughter Rosa takes Manuela to her mother's house as her new cook, we hear:

\begin{tabular}{|l|l|l|}
\hline FILM AN YEAR & SOURCE TEXT & TARGET TEXT \\
\hline$\underline{\text { Todo sobre } \mathbf{m i}}$ & $\begin{array}{l}\text {-¿Cómo te atreves a traer } \\
\text { una puta a casa? (Rosa's } \\
\text { mother) }\end{array}$ & $\begin{array}{l}\text { How dare you } \\
\text { bring a whore home? }\end{array}$ \\
\hline & $\begin{array}{l}\text {-¡Pero una puta! (Rosa's } \\
\text { mother) }\end{array}$ & But a whore! \\
\hline
\end{tabular}

Even though Rosa's mother uses the word "puta", just as Agrado does, her tone of voice manifests her clear disrespect towards Manuela, and the way she utters the insult sounds definitely derogatory. Yet the subtitles do not transmit this difference. Later on, Manuela tries to make it clear to Rosa that she is not a prostitute. She also uses the word "puta", while the TTs shows "whore". In the following example she also uses the verb "putear" (active); its 
translation "to be fucked around" (passive) quite adequately maintains the original meaning.

\begin{tabular}{|l|l|l|}
\hline FILM AND & SOURCE TEXT & TARGET TEXT \\
\hline $\begin{array}{l}\text { Yodo sobre mi } \\
\text { madre (1999) }\end{array}$ & $\begin{array}{l}\text {-Propónmela. Yo no soy } \\
\text { puta. Me han puteado } \\
\text { mucho en la vida, pero } \\
\text { nunca he sido puta } \\
\text { (Manuela) }\end{array}$ & $\begin{array}{l}\text { Tell me. I'm not a } \\
\text { whore.// } \\
\text { I've been fucked } \\
\text { around a lot, / } \\
\text { but I'm not a whore. }\end{array}$ \\
\hline
\end{tabular}

In ¿Qué he hecho yo para merecer esto? the character of Juani embodies the quality of Catholic repression manifested by certain Spaniards of that period. Juani is a friend of Cristal's, who is a prostitute living in the same apartment block. But she does not approve of Cristal's way of earning her living. Juani also hates her only daughter - a young girl with supernatural powers - and treats her badly.

\begin{tabular}{|l|l|l|}
\hline FILM AND YEAR & SOURCE TEXT & TARGET TEXT \\
\hline $\begin{array}{l}\text { ¿Qué he hecho yo } \\
\text { para merecer esto? } \\
\text { (1984) }\end{array}$ & $\begin{array}{l}\text {-Claro que ésta antes de } \\
\text { servir, prefiere meterse a } \\
\text { puta (Juani) }\end{array}$ & $\begin{array}{l}\text { She'd whore around } \\
\text { before working! }\end{array}$ \\
\hline
\end{tabular}

In this example Juani is referring to her daughter Vanesa when she uses the informal expression "meterse a puta", literally "to start working as a whore". The TT translation "to whore around" does maintain the vulgarity of the original expression. Later on, Juani argues with Cristal because of Vanesa, and her tone of voice clearly shows her disrespect towards Cristal's profession: 


\begin{tabular}{|l|l|l|}
\hline FILM AND YEAR & SOURCE TEXT & TARGET TEXT \\
\hline $\begin{array}{l}\text { ¿Qué he hecho yo } \\
\text { para merecer esto? } \\
(1984)\end{array}$ & $\begin{array}{l}-¿ \text { Te critico yo a ti } \\
\text { porque eres puta? (Juani) }\end{array}$ & $\begin{array}{l}\text { Do I criticize you } \\
\text { 'cause you're a whore? }\end{array}$ \\
\hline
\end{tabular}

The same disrespect towards Cristal can be perceived in a comment by Antonio, Gloria's husband:

\begin{tabular}{|l|l|l|}
\hline FILM AND YEAR & SOURCE TEXT & TARGET TEXT \\
\hline $\begin{array}{l}\text { ¿Qué he hecho yo } \\
\text { para merecer esto? } \\
(1984)\end{array}$ & ¡iEs una puta! (Antonio) & She’s a whore! \\
\hline
\end{tabular}

"Putón" also appears very frequently in Almodóvar's dialogues, even though it is not as straightforward and aggressive a word as "puta":

\begin{tabular}{|l|l|ll|}
\hline FILM AND YEAR & SOURCE TEXT & TARGET TEXT \\
\hline $\begin{array}{l}\text { La ley del deseo } \\
\text { (1987) }\end{array}$ & $\begin{array}{l}\text {-¡Por culpa de ese putón, } \\
\text { la de las cartas! } \\
\text { (Antonio's mother) }\end{array}$ & $\begin{array}{l}\text { It's all that whore's } \\
\text { fault! }\end{array}$ \\
\hline Matador (1986) & $\begin{array}{l}\text {-La encuentro un poco } \\
\text { putón (Pilar) }\end{array}$ & $\begin{array}{l}\text { She looks a bit } \\
\text { whorish... }\end{array}$ \\
\hline
\end{tabular}

In these two examples the characters who utter these expressions are the mothers of two of the protagonists. Their age as well as their politeness may justify the use of "putón" in the ST. However, in both cases the TT displays "whore", a term that is stronger than the one used in the original text. In Mujeres the character of Marisa, who is constantly trying to show herself as well-mannered and socially superior, also uses "putón". But strikingly, here the translator has opted for "slut" instead of "whore". 


\begin{tabular}{|l|l|l|}
\hline FILM AND YEAR & SOURCE TEXT & TARGET TEXT \\
\hline $\begin{array}{l}\text { Mujeres al borde } \\
\text { de un ataque de } \\
\text { nervios (1988) }\end{array}$ & $\begin{array}{l}\text {-iAnda y ese putón ahí } \\
\text { arriba bailando en la } \\
\text { ventana! (Marisa) }\end{array}$ & $\begin{array}{l}\text { And that slut in the } \\
\text { window! }\end{array}$ \\
\hline
\end{tabular}

In Mujeres, "zorra", a word as vulgar and even more tasteless than "puta", is used. Here the TT uses the word "bitch", thus keeping the aggressive meaning, even though it does not convey the same rudeness:

\begin{tabular}{|l|l|l|}
\hline FILM AND YEAR & SOURCE TEXT & TARGET TEXT \\
\hline $\begin{array}{l}\text { Mujeres al borde } \\
\text { de un ataque de } \\
\text { nervios (1988) }\end{array}$ & $\begin{array}{l}\text {-Esa zorra con la que ha } \\
\text { estado liado Iván se ha } \\
\text { atrevido a llamar (Lucía) }\end{array}$ & $\begin{array}{l}\text { That bitch Ivan sleeps } \\
\text { with / } \\
\text { had the nerve to call } \\
\text { me. }\end{array}$ \\
\hline
\end{tabular}

Needless to say, it is extremely vulgar in Spanish to place the adjective "puto/a" before any noun in order to express anger. The most common translation of this adjective is "fucking", as is the case in the following examples:

\begin{tabular}{|l|l|l|}
\hline FILM AND YEAR & SOURCE TEXT & TARGET TEXT \\
\hline $\begin{array}{l}\text { Carne trémula } \\
(1997)\end{array}$ & $\begin{array}{l}\text {-¡Abran de una puta vez! } \\
\text { (Sancho) }\end{array}$ & $\begin{array}{l}\text { Just open the fucking } \\
\text { door! }\end{array}$ \\
\hline & $\begin{array}{l}\text {-...me encontré con } \\
\text { vuestro puto entierro por } \\
\text { casualidad (Víctor) }\end{array}$ & $\begin{array}{l}\text {...I just happened to be } \\
\text { near your fucking } \\
\text { funeral! }\end{array}$ \\
\hline & $\begin{array}{l}\text {-Sancho, dame la pistola } \\
\text { de una puta vez (David) }\end{array}$ & $\begin{array}{l}\text { Sancho, give me the } \\
\text { fucking gun! }\end{array}$ \\
\hline
\end{tabular}


Other expressions that convey the same effect as the original can also be found by translating "puta" by "slut of a..." or "goddamn", for example:

\begin{tabular}{|l|l|l|}
\hline FILM AND YEAR & SOURCE TEXT & TARGET TEXT \\
\hline $\begin{array}{l}\text { La ley del deseo } \\
\text { (1987) }\end{array}$ & $\begin{array}{l}-i \text { Que te sonría tu puta } \\
\text { madre! (Tina) }\end{array}$ & $\begin{array}{l}\text { Get your slut of a } \\
\text { mother / } \\
\text { to smile for you! }\end{array}$ \\
\hline $\begin{array}{l}\text { Tacones lejanos } \\
\text { (1991) }\end{array}$ & $\begin{array}{l}\text {-i...si se decide de una } \\
\text { puta vez a confesarnos la } \\
\text { verdad! (Eduardo) }\end{array}$ & $\begin{array}{l}\text {...by telling me } \\
\text { the goddamn truth! }\end{array}$ \\
\hline
\end{tabular}

In the first example, the translator has opted for "slut of a ..." in order to combine it with the noun that it refers to. But, in other texts the translator has omitted this vulgar term:

\begin{tabular}{|c|c|c|}
\hline $\begin{array}{ll}\text { FILM } & \text { AND } \\
\text { YEAR } & \end{array}$ & SOURCE TEXT & TARGET TEXT \\
\hline Kika (1993) & $\begin{array}{l}\text { - ¿Por qué no me dices de } \\
\text { una puta vez que esa } \\
\text { ridícula lesbiana eres tú? } \\
\text { (Andrea) }\end{array}$ & $\begin{array}{l}\text { Why not tell me you're } \\
\text { the ridiculous lesbian? }\end{array}$ \\
\hline $\begin{array}{l}\text { ¿Qué he hecho yo } \\
\text { para merecer esto? } \\
\text { (1984) }\end{array}$ & $\begin{array}{l}\text {-Guay abuela. De puta } \\
\text { madre (Tony) }\end{array}$ & Heavy, grandma... \\
\hline $\begin{array}{l}\text { Todo sobre mi } \\
\text { madre (1999) }\end{array}$ & $\begin{array}{l}\text {-¡Y qué hago! ¡La Lola } \\
\text { me ha dejado sin un puto } \\
\text { duro!.. (Agrado) }\end{array}$ & $\begin{array}{l}\text { What can I do?// } \\
\text { Lola cleaned me out. }\end{array}$ \\
\hline $\begin{array}{l}\text { Carne trémula } \\
\text { (1997) }\end{array}$ & $\begin{array}{l}\text {-...y echamos un polvo } \\
\text { de puta madre (Víctor) }\end{array}$ & $\begin{array}{l}\text {...we had a really great } \\
\text { fuck. }\end{array}$ \\
\hline
\end{tabular}


Maybe in the last two examples the translator thought it inaccurate to add another vulgar word, but in order to respect the film's cultural identity, every dirty word should have been translated thereby maintaining the speaker's rude tone.

"Cabrón" is also found in the films analyzed, but its translation is different in each example:

\begin{tabular}{|l|l|l|}
\hline FILM AND YEAR & SOURCE TEXT & TARGET TEXT \\
\hline $\begin{array}{l}\text { Mujeres al borde } \\
\text { de un ataque de } \\
\text { nervios (1988) }\end{array}$ & -Ese cabrón...(Pepa) & The jerk... \\
\hline $\begin{array}{l}\text { ¿Qué he hecho yo } \\
\text { para merecer esto? } \\
\text { (1984) }\end{array}$ & $\begin{array}{l}\text {-Anda, si el cabrón no se } \\
\text { mueve... (Tony) }\end{array}$ & $\begin{array}{l}\text { The fucker doesn’t } \\
\text { move... }\end{array}$ \\
\hline $\begin{array}{l}\text { Todo sobre mi } \\
\text { madre (1999) }\end{array}$ & $\begin{array}{l}\text {-¡El muy cabrón! } \\
\text { (Manuela) }\end{array}$ & The bastard! \\
\hline $\begin{array}{l}\text { Kika (1993) } \\
\text { (PA dónde vas cabrón? } \\
\text { (Policeman 2) }\end{array}$ & Come back, asshole! \\
\hline $\begin{array}{l}\text { ¿Qué he hecho yo } \\
\text { para merecer esto? } \\
\text { (1984) }\end{array}$ & $\begin{array}{l}\text {-Estoy todo el día } \\
\text { trabajando como un } \\
\text { cabrón ... (Antonio ) }\end{array}$ & $\begin{array}{l}\text { I work my ass off all } \\
\text { day long...// }\end{array}$ \\
\hline
\end{tabular}

From "jerk", "bastard", "asshole" to "fucker", the TTs show four different words for the same source adjective, and the expression "trabajar como un cabrón" is translated as "to work one's ass off", both extremely vulgar expressions. To express her happiness at Manuela's success in the theater, Agrado calls Manuela "cabrona". Translated as "bitch", it has the same effect as in the ST:

\begin{tabular}{|l|l|l|}
\hline FILM AND & SOURCE TEXT & TARGET TEXT \\
$\underline{\text { YEAR }}$ & & \\
\hline
\end{tabular}




\begin{tabular}{|l|l|l|}
\hline $\begin{array}{l}\text { Todo sobre } m i \\
\text { madre (1999) }\end{array}$ & - ¡Cabrona! (Agrado) & ..., bitch! \\
\hline
\end{tabular}

In all these examples, the TT keeps the vulgarity of the original text, thus respecting its original intent.

In Carne trémula there is another example of "cabrón" uttered by Víctor by way of endearment to his about-to-be-born child. In this case the translator has opted for an omission, probably considering that the target audience would not understand such a way to addressing a baby:

\begin{tabular}{|l|l|l|}
\hline FILM AND YEAR & SOURCE TEXT & TARGET TEXT \\
\hline $\begin{array}{l}\text { Carne trémula } \\
(1997)\end{array}$ & $\begin{array}{l}\text {-... cacho cabrón } \\
\text { (Víctor) }\end{array}$ & $: \ldots: \ldots: \ldots:::$ \\
\hline
\end{tabular}

The vulgar insult "maricón" is also to be found in Almodóvar's films. In all these examples this expression is used in an offensive way:

\begin{tabular}{|l|l|l|}
\hline FILM AND YEAR & SOURCE TEXT & TARGET TEXT \\
\hline $\begin{array}{l}\text { La ley del deseo } \\
\text { (1987) }\end{array}$ & $\begin{array}{l}\text {-¡Maricones! (Policeman } \\
1)\end{array}$ & Queers! \\
\hline Matador (1986) & $\begin{array}{l}\text {-Le demostraré que no } \\
\text { soy un maricón (Angel) }\end{array}$ & $\begin{array}{l}\text { I'll show you I'm no } \\
\text { fairy. }\end{array}$ \\
\hline Kika (1993) & -...maricones...(Juana) & ...faggots.. \\
\hline $\begin{array}{l}\text { Todo sobre mi } \\
\text { madre (1999) }\end{array}$ & $\begin{array}{l}\text {-¡Tú estás loco, maricón! } \\
\text { (Agrado) }\end{array}$ & $\begin{array}{l}\text { You're crazy, you } \\
\text { faggot! }\end{array}$ \\
\hline
\end{tabular}


Three different adjectives are used for the same insult in the ST: "queer", "faggot" and "fairy". All are as offensive as they are in the original, but there is a slight difference in usage: "queer" is an old-fashioned term used to relate to a homosexual man; "faggot" is used to refer to a homosexual man in informal American English; and "fairy" is not widely used in colloquial American English. The usage of one or the other word has to do with the translator's personal preferences. In Laberinto de pasiones there is an example that is worth mentioning:

\begin{tabular}{|l|l|l|}
\hline FILM AND YEAR & SOURCE TEXT & TARGET TEXT \\
\hline $\begin{array}{l}\text { Laberinto de } \\
\text { pasiones }(1987)\end{array}$ & $\begin{array}{l}-¿ \text { Y tú mariquita? } \\
\text { (Eusebio) }\end{array}$ & You watch it, faggot! \\
\hline
\end{tabular}

Whereas in the original version the character uses "mariquita", which is not as offensive as "maricón", the translator has opted for "faggot", a more vulgar term than the original one. In Todo sobre mi madre the insult "maricón" uttered by Agrado does not have a pejorative meaning. Agrado uses it to address one of her clients who is trying to beat her up, but who at the end is beaten up himself. As she tries to help him stand up and talks to him nicely, she uses the word "maricón" to calm him down. In this case, the translator has opted to omit the term:

\begin{tabular}{|l|l|l|}
\hline FILM AND YEAR & SOURCE TEXT & TARGET TEXT \\
\hline $\begin{array}{l}\text { Todo sobre } m i \\
\text { madre (1999) }\end{array}$ & $\begin{array}{l}\text {-¡Ayúdame a levantarlo } \\
\text { maricón! (Agrado) }\end{array}$ & Help me get him up! \\
\hline
\end{tabular}


The fact that Spaniards have no qualms about graphically sexual or scatological expressions is apparent from Almodóvar's films, which tend to use a naturalistic mode of dialogue. (Allinson 2001: 42)

Similarly, one finds lots of vulgar expressions that seem very natural for Spaniards, but which translated into English may sound dirty and indecent to an English-speaking audience. Some of these expressions in Almodóvar's films I consider worth mentioning:

\begin{tabular}{|l|l|l|}
\hline FILM AND YEAR & SOURCE TEXT & TARGET TEXT \\
\hline $\begin{array}{l}\text { ¿Qué he hecho yo } \\
\text { para merecer esto? } \\
\text { (1984) }\end{array}$ & $\begin{array}{l}\text {-¿Y tú por qué no te } \\
\text { metes la lengua en el } \\
\text { culo? (Juani) }\end{array}$ & $\begin{array}{l}\text { Why don't you stick } \\
\text { your / } \\
\text { tongue up your ass? }\end{array}$ \\
\hline $\begin{array}{l}\text { ¿Qué he hecho yo } \\
\text { para merecer esto? } \\
\text { (1984) }\end{array}$ & $\begin{array}{l}\text {-¿Por qué no te } \\
\text { maquillas tú la polla? } \\
\text { (Patricia) }\end{array}$ & $\begin{array}{l}\text { Why don't you make } \\
\text { up your cock? }\end{array}$ \\
\hline
\end{tabular}

These two "colorful" expressions have been translated literally for the target audience, even though their humorous effect does not travel well. Expressions such as "to stick one's tongue up one's ass" or "to make up one's cock" make no sense for the target audience, whereas the source audience enjoys these two unexpected comments because they are deeply rooted in colloquial Spanish. Nevertheless, these literal translations keep the original vulgar flavor even though the humor may have been lost.

In Spanish one finds many vulgar expressions in which the speaker literally "shits in something or somebody" in order to show anger; some are more vulgar than others. But blasphemous utterances in 
Spanish are intense and offensive, unlike English which does not have a varied supply of phrases of such intensity. I am referring to expressions such us "cagarse en la mar", "cagarse en la leche" and those that "shit" on Saints, God or the Virgin Mary. The translator thus faces the problem of rendering the same effect in the TT. To quote Bassnett-McGuire (1980), "the shock value of Italian or Spanish blasphemous expressions can only be rendered pragmatically in English by substituting expressions with sexual overtones to produce a comparable shock effect". One of these vulgar examples is found in ¿Qué he hecho yo para merecer esto? when Juani shouts at her broken vase:

\begin{tabular}{|l|l|l|}
\hline FILM AND YEAR & SOURCE TEXT & TARGET TEXT \\
\hline $\begin{array}{l}\text { ¿Qué he hecho yo } \\
\text { para merecer esto? } \\
\text { (1984) }\end{array}$ & $\begin{array}{l}\text {-¡Me cago en los } \\
\text { cáncomos de la } \\
\text { sepultura del Señor! } \\
\text { ¡Mi jarrón! (Juani) }\end{array}$ & $\begin{array}{l}\text { Fucking God } \\
\text { Almighty!/ } \\
\text { My vase! }\end{array}$ \\
\hline
\end{tabular}

Even though the TT does not show a literal translation, it keeps the dirty and vulgar sense of the expression by means of the expletive "fucking", followed by “God Almighty”. Substituting SL religious taboo with TL sexual taboo in films may thus imply a change in the cultural perspective - one that distorts the director's moral vision.

There are two examples, both from Carne trémula, whose TTs show the same translation, even though there is a great difference in the meaning and degree of offensiveness between the two source expressions: 


\begin{tabular}{|l|l|l|}
\hline FILM AND YEAR & SOURCE TEXT & TARGET TEXT \\
\hline $\begin{array}{l}\text { Carne trémula } \\
(1997)\end{array}$ & $\begin{array}{l}-; \text { Cago en la leche! } \\
\text { (Driver) }\end{array}$ & Fucking hell! \\
\hline & $\begin{array}{l}-¡ \text { Me cago en Dios! } \\
\text { (Víctor) }\end{array}$ & Fucking hell! \\
\hline
\end{tabular}

Whereas the driver in the first example literally "shits in the milk", Víctor "shits on God" in the second example. But despite the big difference in meaning between both expressions, the subtitles are identical. In the first instance "cago en la leche" has been translated with a taboo expression that is even stronger than the ST original. This case of overkill in the translation contrasts with the more frequent cases where the translator seems to overlook the original and opts to omit it in the subtitles.

A very recurrent expression that is equally offensive is "cagarse en la madre de uno", literally "to shit on somebody's mother":

\begin{tabular}{|l|l|l|}
\hline FILM AND YEAR & SOURCE TEXT & TARGET TEXT \\
\hline $\begin{array}{l}\text { Tacones lejanos } \\
\text { (1991) }\end{array}$ & $\begin{array}{l}-¿ \text { Y a ti no te dije que no } \\
\text { le vendieras? ¡Me voy a } \\
\text { cagar en tu puta madre! } \\
\text { (Chon) }\end{array}$ & $\begin{array}{l}\text { What did I tell you, } \\
\text { bastard? }\end{array}$ \\
\hline $\begin{array}{l}\text { Mujeres al borde } \\
\text { de un ataque de } \\
\text { nervios (1988) }\end{array}$ & $\begin{array}{l}\text {-¡Me cago en la puta } \\
\text { madre de esta señora! } \\
\text { (Paulina) }\end{array}$ & $\begin{array}{l}\text { That damn fucking } \\
\text { bitch! }\end{array}$ \\
\hline
\end{tabular}

In the first example the translator has opted for the insult "bastard" instead of displaying the literal translation of the ST. But in the second one, a more aggressive insult, "damn fucking bitch", has been 
introduced, ignoring the literal meaning. The insult in the first example is diminished by using "bastard" instead of "I'm gonna shit on your fucking mother" (my own literal translation). In the second example, "I shit on the fucking mother of this lady" (my own literal translation) is replaced by "damn fucking bitch". It may be that the translator's choice in both examples is due to space constraints - as both expressions are too long -, as well as to language barriers, since a literal translation would have made no sense to the target audience.

"Irse a cagar" is a vulgar expression used here as a kind of threat, of revenge. This vulgar expression is commonly used in informal Spanish:

\begin{tabular}{|l|l|l|}
\hline FILM AND YEAR & SOURCE TEXT & TARGET TEXT \\
\hline $\begin{array}{l}\text { Mujeres al borde } \\
\text { de un ataque de } \\
\text { nervios (1988) }\end{array}$ & $\begin{array}{l}\text {-iMira Pepa te voy a } \\
\text { meter un puro por lo de } \\
\text { los tres chítas que te vas } \\
\text { a cagar! (Paulina) }\end{array}$ & $\begin{array}{l}\text { Pepa, you'll pay dearly } \\
\text { for those three Shiites! }\end{array}$ \\
\hline
\end{tabular}

The neutralization of the TT contrasts with the colloquial expression of the ST. Similarly, another expression with the same verb - "cagarse" - is used in informal and vulgar Spanish to imply that somebody is "scared to death of something". Both of these examples exhibit the same translation, which in turn has the same equivalent effect of the original:

\begin{tabular}{|l|l|l|}
\hline FILM AND YEAR & SOURCE TEXT & TARGET TEXT \\
\hline Kika $(1993)$ & $\begin{array}{l}\text {-Yo me cago viva } \\
\text { (Client) }\end{array}$ & Scares me shitless \\
\hline
\end{tabular}




\begin{tabular}{|l|l|l|}
\hline & & \\
\hline $\begin{array}{l}\text { Carne trémula } \\
\text { (1997) }\end{array}$ & $\begin{array}{l}\text {-...cagada de miedo } \\
\text { (Víctor) }\end{array}$ & ....scared shitless. \\
\hline
\end{tabular}

The Spanish expression "irse a la mierda" -"go to hell", "fuck off" - also appears in Mujeres:

\begin{tabular}{|l|l|l|}
\hline FILM AND YEAR & SOURCE TEXT & TARGET TEXT \\
\hline $\begin{array}{l}\text { Mujeres al borde } \\
\text { de un ataque de } \\
\text { nervios (1988) }\end{array}$ & $\begin{array}{l}-i \text { Váyase a la mierda! } \\
\text { (Lucía) }\end{array}$ & Fuck off! \\
\hline & $\begin{array}{l}-i \text { Váyase a la mierda } \\
\text { usted también! (Pepa) }\end{array}$ & Fuck off, yourself! \\
\hline
\end{tabular}

In the second example Pepa (Carmen Maura) addresses her interlocutor Lucía with the same vulgar expression that had previously been used to her. However, Pepa shows her good manners when, despite her rudeness, she addresses Lucía as "usted". This is not reflected in the subtitles due to the non-existence of a formal "you" in modern English, nevertheless, as Ivarsson \& Carroll suggest: “in English, titles ('sir', 'madam', etc.) can sometimes be used to indicate the more formal type of address" (1998: 126).

The word "mierda" ("shit") is also present in some of the dialogues. It is a vulgarity used to refer to something or somebody who is useless or worthless: 


\begin{tabular}{|l|l|l|}
\hline FILM AND YEAR & SOURCE TEXT & TARGET TEXT \\
\hline Kika (1993) & $\begin{array}{l}\text {-Esta mierda, que me ha } \\
\text { vuelto a dejar } \\
\text { tirado...(Manuel } \\
\text { Bandera) }\end{array}$ & Car's dead and... \\
\hline $\begin{array}{l}\text { Carne trémula } \\
(1997)\end{array}$ & $\begin{array}{l}\text {-Pero ide dónde sales tú, } \\
\text { so mierda? (Elena) }\end{array}$ & What is this, you shit! \\
\hline $\begin{array}{l}\text { Todo sobre mi } \\
\text { madre (1999) }\end{array}$ & $\begin{array}{l}\text {-Menudo psicópata de } \\
\text { mierda estás hecho tú, } \\
\text { maricón (Agrado) }\end{array}$ & $\begin{array}{l}\text { What a fucking useless } \\
\text { psychopath! }\end{array}$ \\
\hline
\end{tabular}

In the first example the translator has opted to neutralize the vulgar term and has just replaced "esta mierda", referring to the character's car, for "car's dead". In the second example, the translator has achieved the equivalent derogatory effect of "so mierda" with "you shit". In the last one "mierda" is modifying the noun "psicópata", and the translation displays the adjective "fucking" in order to keep the vulgarity of the original.

There is another word that also belongs to the realm of blasphemous utterances that appear all over Almodóvar's films: "hostia", literally "host" or "consecrated wafer". It is common in Spanish to "threaten to give somone or more (hostias)" in anger:

\begin{tabular}{|l|l|l|}
\hline FILM AND YEAR & SOURCE TEXT & TARGET TEXT \\
\hline Matador (1986) & $\begin{array}{l}\text {-Anda, ve y dale un par } \\
\text { de hostias a ver si se } \\
\text { reanima (Doctor) }\end{array}$ & $\begin{array}{l}\text { Slap him hard, see } \\
\text { if he comes to. }\end{array}$ \\
\hline ¡Átame! (1990) & -¿Qué quieres, que te dé & You want me to \\
\hline
\end{tabular}




\begin{tabular}{|l|l|l|}
\hline & $\begin{array}{l}\text { otra hostia y te rompa } \\
\text { otra muela? (Ricky) }\end{array}$ & break another tooth? \\
\hline $\begin{array}{l}\text { Carne trémula } \\
(1997)\end{array}$ & $\begin{array}{l}\text {-¿Qué quieres, que te } \\
\text { meta otra hostia? } \\
\text { (Víctor) }\end{array}$ & $\begin{array}{l}\text { You want me to hit } \\
\text { you again? }\end{array}$ \\
\hline $\begin{array}{l}\text { Carne trémula } \\
(1997)\end{array}$ & $\begin{array}{l}\text {-Pero le ha dado un } \\
\text { rebote y me ha dado una } \\
\text { hostia con un neceser } \\
\text { (Sancho) }\end{array}$ & $\begin{array}{l}\text { But she flipped out...// } \\
\text { and belted me } \\
\text { with her beauty case. }\end{array}$ \\
\hline
\end{tabular}

It is interesting to note that the second example displays a neutralization of the blasphemous expression, while the rest exhibit euphemisms: "slap him hard", "hit you", "belted me". Thus the intensity of the original dialogues is completely lost in these translations. Maybe the insertion of the expression "to kick the shit out of somebody" would have been more in keeping with the flavor of the identity of the original text, but its length may have been one of the constraints that kept the translator from choosing it.

Another use of "hostia" is in the expression "ser la hostia" to refer to something that is "bloody amazing", implying admiration. By the same token, it can be used to express anger.

\begin{tabular}{|l|l|l|}
\hline FILM AND YEAR & SOURCE TEXT & TARGET TEXT \\
\hline $\begin{array}{l}\text { Carne trémula } \\
(1997)\end{array}$ & $\begin{array}{l}\text {-¡Es la hostia tío, el } \\
\text { Caminero es la hostia! } \\
\text { (Víctor) }\end{array}$ & $\begin{array}{l}\text { Caminero's a knock- } \\
\text { out! }\end{array}$ \\
\hline & -¡Esto es la hostia! & Fuck that! \\
\hline
\end{tabular}




\begin{tabular}{|l|l|l|}
\hline & (David) & \\
& & \\
\hline
\end{tabular}

In the first example, the admiration exhibited towards a soccer goal keeper is translated as "to be a knock-out", which implies a neutralization of the original vulgarity. In the second example, David's anger at Victor who is constantly chasing his wife retains a certain vulgarity in the subtitle with the expression "fuck that". As said above, in the latter example, the translator's strategy has been to substitute a SL religious taboo for a TL sexual taboo.

The rude expression "tener mala hostia" means to "be in a foul mood". In the following example the TT exhibits the expression "to have a filthy temper". Here the adjective "filthy" preserves the original meaning without completely transmitting the vulgarity of the source expression. It therefore constitutes a euphemism of the original expression:

\begin{tabular}{|l|l|l|}
\hline FILM AND YEAR & SOURCE TEXT & TARGET TEXT \\
\hline $\begin{array}{l}\text { Carne trémula } \\
(1997)\end{array}$ & $\begin{array}{l}\text {-Y te advierto que como } \\
\text { todos los cojos, tengo } \\
\text { muy mala hostia } \\
\text { (David) }\end{array}$ & $\begin{array}{l}\text { And like all cripples,/ } \\
\text { I've got a filthy } \\
\text { temper. }\end{array}$ \\
\hline
\end{tabular}

It may be said, then, by way of summary that some of the sexual and scatological expressions that appear in Almodóvar's films are translated adequately in the subtitles, so that in most cases the original vulgarity is transmitted. Indeed, most of the examples shown in this section display translations that attain the closest equivalent. There are 
also several instances that exhibit neutralizations of the original word or expression, implying a deviation from the ST by translators in their attempt to soften some of the vulgar terms of the original. As for blasphemous language, as English does not have as wide a range of blasphemous vocabulary, the translations tend to exhibit euphemisms or omissions. It is by means of these modifications in the TTs that the translators seem to soften Almodóvar's scatological language for the target audience in an attempt to conform to the target norms.

In other words, the translators of Almodóvar's films have for the most part procured an equivalent effect in the translation of the director's insulting and scatological expressions. While there are some instances in which, surprisingly, the translations display omissions or euphemisms, in the main the translators have respected the original version. Since the particular language conveyed in the original is central to the message and the action of Almodóvar's films, it is important that these audiovisual translators should try to be faithful to the language of the ST.

\subsubsection{Expressions Concerning Sexual and Bodily Functions}

There are many expressions in Spanish that refer to sexual or bodily functions, and numerous examples of these can be found in the dialogues of Almodóvar's films.

The word "coño" ("cunt") is very common in vulgar Spanish. As part of an expression it may show disagreement and anger, as in "qué coño...". I would like to analyze some instances in which the word 
"coño", or its synonym, "chocho" - which may be less vulgar than the former - appear. An equivalent translation for the word "chocho" could be "pussy", as seen in this example from Kika:

\begin{tabular}{|l|l|l|}
\hline FILM AND YEAR & SOURCE TEXT & TARGET TEXT \\
\hline Kika (1993) & $\begin{array}{l}\text {-Donde se ponga un buen } \\
\text { chocho que se quite todo } \\
\text { lo demás (Juana) }\end{array}$ & $\begin{array}{l}\text { Nothing compares to } \\
\text { good pussy... }\end{array}$ \\
\hline
\end{tabular}

Yet, the word "chocho" has usually been translated as "cunt" and "twat", both of which convey a more vulgar and dirty meaning than the original:

\begin{tabular}{|l|l|l|}
\hline FILM AND YEAR & SOURCE TEXT & TARGET TEXT \\
\hline Matador (1986) & ¡Chochos! (Chief) & Cunts! \\
\hline iÁtame! (1990) & $\begin{array}{l}\text {-Pues no sé qué es peor, } \\
\text { que se te noten las bragas } \\
\text { o que se te note el } \\
\text { chocho (Lola) }\end{array}$ & $\begin{array}{l}\text { What's worse, showing } \\
\text { your / panties or } \\
\text { showing your twat? }\end{array}$ \\
\hline $\begin{array}{l}\text { ¿Qué he hecho yo } \\
\text { para merecer esto? } \\
\text { (1984) }\end{array}$ & $\begin{array}{l}\text {-Mira Cristal, a veces } \\
\text { pienso que sólo tienes } \\
\text { sensibilidad en el chocho } \\
\text { (Juani) }\end{array}$ & $\begin{array}{l}\text { I think you only feel } \\
\text { with your cunt! }\end{array}$ \\
\hline
\end{tabular}

In the following examples, "coño"has been translated by "cunt":

\begin{tabular}{|l|l|l|}
\hline FILM AND YEAR & SOURCE TEXT & TARGET TEXT \\
\hline $\begin{array}{l}\text { ¿Qué he hecho yo } \\
\text { para merecer esto? } \\
\text { (1984) }\end{array}$ & $\begin{array}{l}\text {-Por eso tengo que ir con } \\
\text { prostitutas que tienen el } \\
\text { coño más dado de si por }\end{array}$ & $\begin{array}{l}\text { That's why I've got to } \\
\text { go with whores...// } \\
\text {....with big cunts }\end{array}$ \\
\hline
\end{tabular}




\begin{tabular}{|l|l|l|}
\hline & el uso... (Client) & stretched by use... \\
\hline ¡Átame! (1990) & $\begin{array}{l}\text { - A ver cómo la desato } \\
\text { sin tocarle el coño } \\
\text { (Ricky) }\end{array}$ & $\begin{array}{l}\text { Careful not to touch her } \\
\text { cunt! }\end{array}$ \\
\hline
\end{tabular}

Nevertheless, here is an example in which the word "coño" has been translated as "pussy", a less offensive meaning:

\begin{tabular}{|l|l|l|}
\hline FILM AND YEAR & SOURCE TEXT & TARGET TEXT \\
\hline $\begin{array}{l}\text { Carne trémula } \\
(1997)\end{array}$ & $\begin{array}{l}\text {-...no te lances al coño } \\
\text { tan pronto (Clara) }\end{array}$ & $\begin{array}{l}\text {...don't dive } \\
\text { at my pussy so fast. }\end{array}$ \\
\hline
\end{tabular}

In Almodóvar's films some of the translations into English are substituted by other expressions when literal translation is impossible:

\begin{tabular}{|l|l|l|}
\hline FILM AND YEAR & SOURCE TEXT & TARGET TEXT \\
\hline iÁtame! (1990) & $\begin{array}{l}\text {-...porque a la mujer del } \\
\text { productor se le ponga en } \\
\text { la pipa del coño que } \\
\text { quiere el sofá... (Lola) }\end{array}$ & $\begin{array}{l}\text { Just because the } \\
\text { producer's wife / } \\
\text { has hot pants for the } \\
\text { couch. }\end{array}$ \\
\hline
\end{tabular}

"To have hot pants" is a clever piece of substitution, as it keeps the matter in the field of the taboo or semi-taboo.

In Mujeres, there is a comment in which the word "chocho" is translated as "ass", a word that especially in American English does refer to the female genitals, and so respects the vulgarity of the original: 


\begin{tabular}{|l|l|l|}
\hline FILM AND YEAR & SOURCE TEXT & TARGET TEXT \\
\hline $\begin{array}{l}\text { Mujeres al borde } \\
\text { de un ataque de } \\
\text { nervios (1988) }\end{array}$ & $\begin{array}{l}\text {-Se lo tengo dicho. En } \\
\text { esa moto no se sube otro } \\
\text { chocho más que el mío } \\
\text { (Ana) }\end{array}$ & $\begin{array}{l}\text { My ass is the only one } \\
\text { allowed on that bike. }\end{array}$ \\
\hline
\end{tabular}

In $K i k a$ there is a comment uttered by the protagonist, through which she expresses her anger, and deception in a harsh tone after being raped:

\begin{tabular}{|l|l|l|}
\hline FILM AND YEAR & SOURCE TEXT & TARGET TEXT \\
\hline Kika (1993) & $\begin{array}{l}\text {-¡Me toca el coño la } \\
\text { publicidad! (Kika) }\end{array}$ & $\begin{array}{l}\text { I don’t give a fuck } \\
\text { about publicity! }\end{array}$ \\
\hline
\end{tabular}

The vulgar expression "not to give a fuck" is indeed the English equivalent for the original expression, thereby respecting the vulgarity of the original

On the other hand, there are expressions with "coño" that simply express the anger of the speaker: "qué coño..", “cómo coño...", "por qué coño...", “quién coño...", “cuándo coño...”. A good rendering of this into English should include "the fuck" in order to transmit the speaker's anger and rudeness and thus to produce the equivalent effect, as in the following examples:

\begin{tabular}{|l|l|l|}
\hline FILM AND YEAR & SOURCE TEXT & TARGET TEXT \\
\hline Tacones lejanos & $-¿$ Se puede saber qué & What the fuck are you \\
\hline
\end{tabular}




\begin{tabular}{|l|l|l|}
\hline (1991) & $\begin{array}{l}\text { coño estás haciendo? } \\
\text { (Alberto) }\end{array}$ & doing? \\
\hline Kika (1993) & $\begin{array}{l}\text {-iCuándo coño me } \\
\text { dejará en paz! (Ramón) }\end{array}$ & $\begin{array}{l}\text { When the fuck will } \\
\text { she } \\
\text { leave me alone!?? }\end{array}$ \\
\hline Kika (1993) & $\begin{array}{l}\text {-Entonces ¿qué coño has } \\
\text { dicho? (Nicholas) }\end{array}$ & $\begin{array}{l}\text { What the fuck did you } \\
\text { say? }\end{array}$ \\
\hline $\begin{array}{l}\text { Kika (1993) } \\
\text { (1997) }\end{array}$ & $\begin{array}{l}\text {-¿Qué coño estarán } \\
\text { diciendo? (Andrea) }\end{array}$ & $\begin{array}{l}\text { What the fuck are they } \\
\text { saying? }\end{array}$ \\
\hline $\begin{array}{l}\text { Carne trémula } \\
\text { (1997) }\end{array}$ & $\begin{array}{l}\text {-iPero a mi qué coño me } \\
\text { importa lo que diga Lou } \\
\text { Reed! (Elena) }\end{array}$ & $\begin{array}{l}\text { I don’t give a fuck } \\
\text { what Lou Reed says! }\end{array}$ \\
\hline $\begin{array}{l}\text {-Entonces ¿por qué coño } \\
\text { te vas a quedar conmigo? } \\
\text { (David) }\end{array}$ & $\begin{array}{l}\text { Then, why the fuck } \\
\text { stay with me? }\end{array}$ \\
\hline $\begin{array}{l}\text { ¿adre (1999) } \\
\text { para merecer esto? } \\
\text { (1984) }\end{array}$ & $\begin{array}{l}\text {-Lucas i¿qué coño haces } \\
\text { en la cocina?! (Patricia) }\end{array}$ & $\begin{array}{l}\text { What the fuck are you } \\
\text { doing in the kitchen! }\end{array}$ \\
(Nina) & $\begin{array}{l}\text {-¿Y tú quién coño eres? } \\
\text { Who the fuck are you? }\end{array}$ & \\
\hline
\end{tabular}

All these subtitles keep the same expression in English, thus showing a homogeneous quality in the translation of expressions with "coño".

Several translations, however, show the omission of the same vulgar expression:

\begin{tabular}{|l|l|l|}
\hline FILM AND YEAR & SOURCE TEXT & TARGET TEXT \\
\hline
\end{tabular}




\begin{tabular}{|c|c|c|}
\hline $\begin{array}{l}\text { La ley del deseo } \\
\text { (1987) }\end{array}$ & $\begin{array}{l}\text {-Pero ¿qué coño quieres? } \\
\text { (Juan) }\end{array}$ & What are you after? \\
\hline $\begin{array}{l}\text { Mujeres al borde } \\
\text { de un ataque de } \\
\text { nervios }(1988)\end{array}$ & $\begin{array}{l}\text {-Y si te atacan ¿cómo } \\
\text { coño te defiendes? (Ana) }\end{array}$ & What if you're held up? \\
\hline ;Átame! (1990) & $\begin{array}{l}\text {-i¿...o qué coño te } \\
\text { pasa?! (Max) }\end{array}$ & ...or what?! \\
\hline $\begin{array}{l}\text { Tacones lejanos } \\
\text { (1991) }\end{array}$ & $\begin{array}{l}\text {-ið’Pa' qué coño crees tú } \\
\text { que le he 'pegao' una } \\
\text { pedrada a ese pobre } \\
\text { hombre que casi lo } \\
\text { mato?! (Chon) }\end{array}$ & $\begin{array}{l}\text { Why do you think I } \\
\text { nearly } \\
\text { killed that poor man? }\end{array}$ \\
\hline $\begin{array}{l}\text { Carne trémula } \\
\text { (1997) }\end{array}$ & $\begin{array}{l}\text {-¿Qué coño haces aquí? } \\
\text { (Elena) }\end{array}$ & $\begin{array}{l}\text { What are you doing } \\
\text { here? }\end{array}$ \\
\hline $\begin{array}{l}\text { ¿Qué he hecho yo } \\
\text { para merecer esto? } \\
\text { (1984) }\end{array}$ & $\begin{array}{l}\text {-No sé qué coño hace tu } \\
\text { vecina Juani...(Antonio) }\end{array}$ & $\begin{array}{l}\text { Everytime your } \\
\text { neighbor } \\
\text { Juani gets in the lift,... }\end{array}$ \\
\hline $\begin{array}{l}\text { ¿Qué he hecho yo } \\
\text { para merecer esto? } \\
(1984)\end{array}$ & $\begin{array}{l}\text {-Y no quiero que vayas a } \\
\text { trabajar por ahí ¡No sé } \\
\text { cómo coño tengo que } \\
\text { decírtelo! (Antonio) }\end{array}$ & $\begin{array}{l}\text { And I don't want you } \\
\text { to } \\
\text { work anywhere, get } \\
\text { that? }\end{array}$ \\
\hline
\end{tabular}

In all of these examples the vulgar expressions are omitted, and it does not seem to be a matter of a particular translator's taste, or maybe due to space constraints. For in the same film both are present: examples of a 
perfectly adequate translation of an expression, as well as examples in which the same translator has opted for its omission. I consider that it would be preferable for the translators to be consistent. The best choice is fidelity to the original text in preserving its spirit in the translation. I believe that the subtitler's goal should be to focus on transmitting everything that exists in the original, taking into account the time and space constraints of subtitles.

As regards male genitals, there is a wide variety of vulgar synonyms such as "polla", "rabo", "pollón" in the dialogues. The most frequently used word seems to be "polla", its equivalents in English being "cock", "prick" or "dick".

\begin{tabular}{|l|l|l|}
\hline FILM AND YEAR & SOURCE TEXT & TARGET TEXT \\
\hline iÁtame! (1990) & $\begin{array}{l}\text {-Estos cabrones sólo me } \\
\text { han dejado sana la polla } \\
\text { (Ricky) }\end{array}$ & $\begin{array}{l}\text { The only thing the } \\
\text { bastards / } \\
\text { left alone was my cock. }\end{array}$ \\
\hline
\end{tabular}

In Todo sobre mi madre, there is a highly humorous dialogue for the source audience. It is between Agrado, Huma, Manuela and Sister Rosa who talk about penises and their relationship to them:

\begin{tabular}{|l|l|l|}
\hline FILM AND YEAR & SOURCE TEXT & TARGET TEXT \\
\hline $\begin{array}{l}\text { Todo sobre mi } \\
\text { madre (1999) }\end{array}$ & $\begin{array}{l}\text {-Hasta cuando me estoy } \\
\text { comiendo una polla sé } \\
\text { ser discreta (Agrado) }\end{array}$ & $\begin{array}{l}\text { I'm a model of } \\
\text { discretion, even / } \\
\text { when I'm sucking } \\
\text { someone's cock. }\end{array}$ \\
\hline
\end{tabular}




\begin{tabular}{|l|l|l|}
\hline & $\begin{array}{l}\text {-La cantidad de pollas } \\
\text { que me habré comido... } \\
\text { (Agrado) }\end{array}$ & $\begin{array}{l}\text { I've sucked lots } \\
\text { in public spaces... }\end{array}$ \\
\hline & $\begin{array}{l}\text {-¡El tiempo que hace que } \\
\text { no me como yo una } \\
\text { polla! (Huma) }\end{array}$ & $\begin{array}{l}\text { It's been ages since I } \\
\text { sucked one! }\end{array}$ \\
\hline & $\begin{array}{l}\text {-Pues a mi me encanta la } \\
\text { palabra "polla". Y } \\
\text { "pollón" (Rosa) }\end{array}$ & $\begin{array}{l}\text { I love the word cock.// } \\
\text { And prick. }\end{array}$ \\
\hline
\end{tabular}

The second and third examples exhibit a neutralization of the vulgar word in the TT: instead of including an equivalent, the translator has referred to it as "lots", and "one". Perhaps the translator thought it better to avoid repeating the same offensive word in a dialogue in which it appears several times, a substitution by pronouns sounding less vulgar. This film has numerous examples of this particular word. At one point Nina seems curious about Agrado's sexual condition: she is a transsexual but with a penis.

\begin{tabular}{|l|l|l|}
\hline FILM AND YEAR & SOURCE TEXT & TARGET TEXT \\
\hline $\begin{array}{l}\text { Todo sobre } m i \\
\text { madre (1999) }\end{array}$ & $\begin{array}{l}\text {-Agrado, enséñame la } \\
\text { polla (Nina) }\end{array}$ & Show me your cock. \\
\hline & $\begin{array}{l}\text {-Me voy, pero ¿luego me } \\
\text { enseñas la polla? (Nina) }\end{array}$ & $\begin{array}{l}\text { Will you show me } \\
\text { your cock later? }\end{array}$ \\
\hline & -Después te enseño la & I'll show it to you \\
\hline
\end{tabular}




\begin{tabular}{|l|l|l|}
\hline & $\begin{array}{l}\text { polla y te comes un pizco } \\
\text { (Agrado) }\end{array}$ & and you can lick it. \\
\hline
\end{tabular}

Once again, because of the continuous repetition of the word, the translator may have decided to substitute it for a pronoun, to avoid repeating it several times. Agrado is involved in another conversation about penises, and in this exchange Mario "begs" her to give him oral sex. "Polla" is translated as "cock" in every sentence. This conversation becomes truly humorous as Agrado talks about something so private in such a natural way:

\begin{tabular}{|l|l|l|}
\hline FILM AND YEAR & SOURCE TEXT & TARGET TEXT \\
\hline $\begin{array}{l}\text { Todo sobre } m i \\
\text { madre (1990) }\end{array}$ & $\begin{array}{l}\text {-¿Tú no me harías una } \\
\text { mamada? (Mario) }\end{array}$ & $\begin{array}{l}\text { Would you give me a } \\
\text { blow-job? }\end{array}$ \\
\hline & $\begin{array}{l}\text {-Oye, ¿aquí no os entra } \\
\text { en la cabeza que yo estoy } \\
\text { jubilada? (Agrado) }\end{array}$ & $\begin{array}{l}\text { Can't you get it into } \\
\text { your heads that I'm } \\
\text { retired? }\end{array}$ \\
\hline & $\begin{array}{l}\text {-No quiero que pienses } \\
\text { eso. Pero como llevo } \\
\text { todo el día nervioso } \\
\text { pues... creo que una } \\
\text { mamada me relajaría... } \\
\text { (Mario) }\end{array}$ & $\begin{array}{l}\text { I don't want you } \\
\text { to think that,...// } \\
\text {...but as I've been on } \\
\text { edge } \\
\text { all day...// } \\
\ldots \text {..I think a blow-job } \\
\text { would relax me. }\end{array}$ \\
\hline & $\begin{array}{l}\text {-Mámamela tú a mi, que } \\
\text { yo también estoy } \\
\text { nerviosa....(Agrado) }\end{array}$ & $\begin{array}{l}\text { You give me one, } \\
\text { I'm on edge too. }\end{array}$ \\
\hline
\end{tabular}




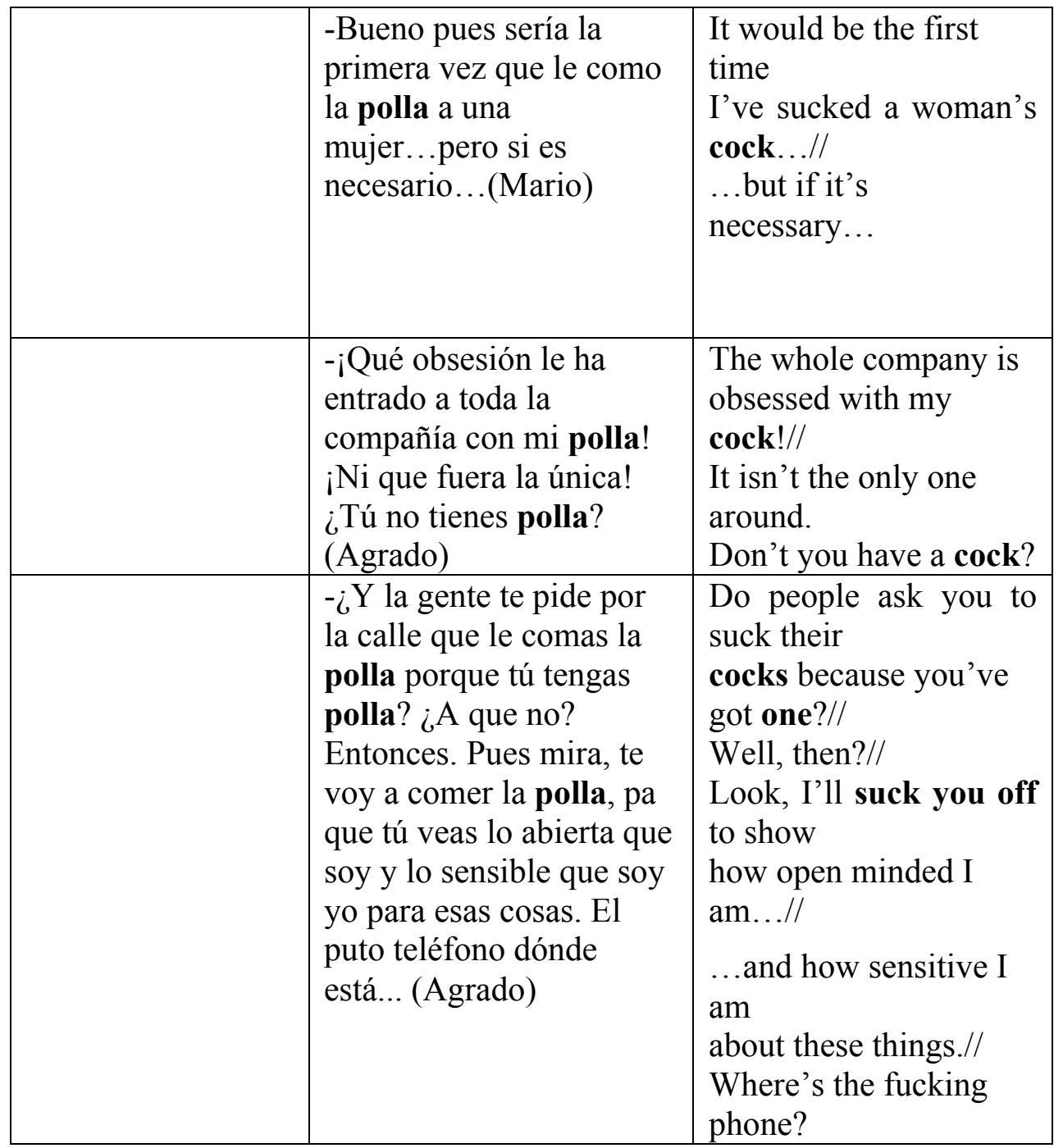

The subtitles keep the vulgarity of the original precisely by including the equivalents for dirty terms used in the ST. Only in one instance is there is a neutralization of the vulgar term by means of the pronoun "it" in the fourth example above.

There is an expression in Spanish with the word "polla" used in the plural, preceded by the word "ni" - "ni pollas" - that expresses disagreement with or rejection of someone. Such an example can be found in ¿Qué he hecho yo para merecer esto?, when Tony - a young 
drug dealer - gives some cocaine to his neighbor Cristal, who appreciates it but without offering to pay him for it. He replays by saying:

\begin{tabular}{|l|l|l|}
\hline FILM AND YEAR & SOURCE TEXT & TARGET TEXT \\
\hline $\begin{array}{l}\text { ¿Qué he hecho yo } \\
\text { para merecer esto? } \\
(1984)\end{array}$ & $\begin{array}{l}\text {-¡Qué gracias ni pollas! } \\
\text { (Tony) }\end{array}$ & Thanks, my ass! \\
\hline
\end{tabular}

Here, the translator has chosen "my ass" to convey the vulgarity of the ST.

In all of these examples there seems to be an agreement to translate "polla" as "cock". Similarly, some of the dialogues uttered by certain characters contain another synonym for penis: "rabo". According to dictionaries, the translation of "rabo" into English is "dick" or "cock", as can be seen in the examples that follow:

\begin{tabular}{|l|l|l|}
\hline FILM AND YEAR & SOURCE TEXT & TARGET TEXT \\
\hline $\begin{array}{l}\text { Tacones lejanos } \\
(1991)\end{array}$ & -Mira su rabo (Paula) & Look, his cock. \\
\hline Kika (1993) & $\begin{array}{l}\text {-Yo con que tengan buen } \\
\text { fondo y buen rabo, yo } \\
\text { me enamoro (Kika) }\end{array}$ & $\begin{array}{l}\text { A good heart, } \\
\text { a good dick, I fall in } \\
\text { love. }\end{array}$ \\
\hline $\begin{array}{l}\text { Todo sobre mi } \\
\text { madre (1999) }\end{array}$ & $\begin{array}{l}\text {-Para hacer la carrera no } \\
\text { hacen falta kilos, sino un } \\
\text { buen rabo (Esteban) }\end{array}$ & $\begin{array}{l}\text { You don't need pounds } \\
\text { for that / } \\
\text { you need a big dick. }\end{array}$ \\
\hline $\begin{array}{l}\text { Todo sobre mi } \\
\text { madre (1999) }\end{array}$ & $\begin{array}{l}\text {-...y además un buen } \\
\text { rabo (Agrado) }\end{array}$ & and a big dick as well. \\
\hline
\end{tabular}


\begin{tabular}{|l|l|l|}
\hline & & \\
\hline
\end{tabular}

All of these examples show consistency of translation, with either "cock" or "dick". However, there is an example in Kika in which the translator has opted for the synonym "pipe", instead of the two other ones. Here, the translation does not reflect the vulgarity of the original "rabo", as "pipe" is considered to be a milder version of the other English synonyms:

\begin{tabular}{|l|l|l|}
\hline FILM AND YEAR & SOURCE TEXT & TARGET TEXT \\
\hline $\begin{array}{l}\text { ¿Qué he hecho yo } \\
\text { para merecer esto? } \\
\text { (1984) }\end{array}$ & $\begin{array}{l}\text {-Si es que la pobre tiene } \\
\text { una necesidad de } \\
\text { rabo...(Cristal) }\end{array}$ & $\begin{array}{l}\text { What the poor thing } \\
\text { needs / } \\
\text { is a nice big pipe... }\end{array}$ \\
\hline
\end{tabular}

In my viewing of the films I could only find two examples in two different films in which the word "paquete" was used to refer to the male genitals. The English equivalent would be "bulge" or "lunchbox", words that in both Spanish and English are vulgar, although not very rude. Yet, the translations do not show these equivalents in the TT:

\begin{tabular}{|l|l|l|}
\hline FILM AND YEAR & SOURCE TEXT & TARGET TEXT \\
\hline $\begin{array}{l}\text { La ley del deseo } \\
\text { (1987) }\end{array}$ & $\begin{array}{l}\text {-Refriégate el paquete } \\
\text { contra el cristal (Voice) }\end{array}$ & $\begin{array}{l}\text { Rub your cock against } \\
\text { the glass. }\end{array}$ \\
\hline $\begin{array}{l}\text { Mujeres al borde } \\
\text { de un ataque de } \\
\text { nervios (1988) }\end{array}$ & $\begin{array}{l}\text {-iSi le está cogiendo el } \\
\text { paquete! (Ana) }\end{array}$ & $\begin{array}{l}\text { She's going for his } \\
\text { balls. }\end{array}$ \\
\hline
\end{tabular}


Here, even though "cock" and "balls" are not the exact equivalents for the original word, they do produce the same effect in the translation, as they are as vulgar as the source term.

On the other hand, there are occasions in which there is a word or expression whose meaning is not that vulgar in the ST, and yet surprisingly the translator has chosen a vulgar word to replace it. This can be seen in two dialogues from Tacones lejanos. In the first one Rebeca is surprised to see a mole on Letal's penis:

\begin{tabular}{|l|l|l|}
\hline FILM AND YEAR & SOURCE TEXT & TARGET TEXT \\
\hline $\begin{array}{l}\text { Tacones lejanos } \\
(1991)\end{array}$ & $\begin{array}{l}\text {-Anda, si tienes un lunar } \\
\text { en el glande (Rebeca) }\end{array}$ & $\begin{array}{l}\text { You have a mole on } \\
\text { your cock. }\end{array}$ \\
\hline
\end{tabular}

The dialogue takes place in jail. While Rebeca is talking to Paula she realizes that Letal, the man she has had sex with, is the same man that Paula used to live with. She finds this out because of the mole on his penis, and thanks to a photograph that Paula shows her:

\begin{tabular}{|l|l|l|}
\hline FILM AND YEAR & SOURCE TEXT & TARGET TEXT \\
\hline $\begin{array}{l}\text { Tacones lejanos } \\
(1991)\end{array}$ & $\begin{array}{l}-¿ \text { Y tenía un lunar en el } \\
\text { glande? (Rebeca) }\end{array}$ & $\begin{array}{l}\text { He had a mole on his } \\
\text { cock? }\end{array}$ \\
\hline & $\begin{array}{l}\text {-Lo importante es el } \\
\text { glande, no el lunar } \\
\text { (Paula) }\end{array}$ & $\begin{array}{l}\text { It's the cock that } \\
\text { counts. }\end{array}$ \\
\hline
\end{tabular}


It was astonishing to find the word "glande" in the ST - the formal and technical way of referring to a part of the penis - translated with vulgar word "cock", instead of "glans". This shows a clear inconsistency, as the translator included a vulgar term instead of preserving the lack of vulgarity in the ST.

After analyzing vulgar sexual words that refer to the male and female genitals, I will deal with the synonyms for the expression "to have sex". In Spanish, the most common vulgar terms to express this activity are "follar", "tirarse", "echar un polvo" and "joder". The following examples contain the verb "follar" in the ST:

\begin{tabular}{|l|l|l|}
\hline FILM AND YEAR & SOURCE TEXT & TARGET TEXT \\
\hline $\begin{array}{l}\text { Laberinto de } \\
\text { pasiones (1982) }\end{array}$ & $\begin{array}{l}\text {-...porque no pensaba en } \\
\text { nada más que en follar, } \\
\text { follar y follar (Guy 1) }\end{array}$ & $\begin{array}{l}\text {...She was } \\
\text { only interested in } \\
\text { screwing. }\end{array}$ \\
\hline $\begin{array}{l}\text { La ley del deseo } \\
\text { (1987) }\end{array}$ & $\begin{array}{l}\text {-Pídeme que te folle } \\
\text { (Voice) }\end{array}$ & Ask me to fuck you. \\
\hline $\begin{array}{l}\text { La ley del deseo } \\
\text { (1987) }\end{array}$ & -iFóllame! (Antonio) & Fuck me! \\
\hline $\begin{array}{l}\text { La ley del deseo } \\
\text { (1987) }\end{array}$ & $\begin{array}{l}\text {-¿No te importa que no } \\
\text { follemos? (Juan) }\end{array}$ & $\begin{array}{l}\text { You don't care if we } \\
\text { don't } \\
\text { screw, do you? }\end{array}$ \\
\hline $\begin{array}{l}\text { Matador (1986) } \\
\text { me folles (Julia) }\end{array}$ & $\begin{array}{l}\text {-No me importa que no } \\
\text { mou don't have to }\end{array}$ & Young \\
\hline
\end{tabular}




\begin{tabular}{|l|l|l|}
\hline & screw me. \\
\hline $\begin{array}{l}\text { Mujeres al borde } \\
\text { de un ataque de } \\
\text { nervios (1988) }\end{array}$ & $\begin{array}{l}\text {-...menos lo de follar... } \\
\text { (Pepa) }\end{array}$ & $\begin{array}{l}\text {..except for the } \\
\text { fucking, }\end{array}$ \\
\hline $\begin{array}{l}\text { Mujeres al borde } \\
\text { de un ataque de } \\
\text { nervios (1988) }\end{array}$ & $\begin{array}{l}\text {-Follamos todo el tiempo } \\
\text { sin parar, eso sí } \\
\text { (Candela) }\end{array}$ & $\begin{array}{l}\text { We fucked the whole } \\
\text { weekend. }\end{array}$ \\
\hline $\begin{array}{l}\text { Todo sobre mi } \\
\text { madre (1999) }\end{array}$ & $\begin{array}{l}\text {-iPero cómo se te ocurrió } \\
\text { follar con Lola! } \\
\text { (Manuela) }\end{array}$ & $\begin{array}{l}\text { Why the hell } \\
\text { did you screw Lola? }\end{array}$ \\
\hline $\begin{array}{l}\text { ¿Qué he hecho yo } \\
\text { para merecer esto? } \\
\text { (1984) }\end{array}$ & $\begin{array}{l}\text {-Pero un hombre no folla } \\
\text { con los brazos (Client) }\end{array}$ & $\begin{array}{l}\text { But a man doesn't } \\
\text { screw } \\
\text { with his arms. }\end{array}$ \\
\hline
\end{tabular}

The words "fuck" and "screw" are used here indiscriminately to translate the original verb, in order to produce the equivalent effect in the translation.

There are two examples in which the verb "follar" appears, while the translations display euphemisms that soften the vulgarity and distort the identity of the original:

\begin{tabular}{|l|l|l|}
\hline FILM AND YEAR & SOURCE TEXT & TARGET TEXT \\
\hline $\begin{array}{l}\text { Laberinto de } \\
\text { pasiones }(1982)\end{array}$ & $-¿$ Y qué tal folla? (Queti) & Is he good in bed? \\
\hline $\begin{array}{l}\text { Carne trémula } \\
(1997)\end{array}$ & $\begin{array}{l}-¿ \text { Qué quieres, que } \\
\text { esperemos a ver cómo } \\
\text { matan o se follan a esa } \\
\text { tía? (Sancho) }\end{array}$ & $\begin{array}{l}\text { You want to wait till } \\
\text { that girl / } \\
\text { is raped and killed? }\end{array}$ \\
\hline
\end{tabular}


\begin{tabular}{|l|l|l|}
\hline & \\
\hline
\end{tabular}

In Carne trémula Víctor desires to become "el mejor follador del mundo", because of a past disappointment with a girl. Every time he refers to this idea, the translator opts for a euphemism in the TT:

\begin{tabular}{|l|l|l|}
\hline FILM AND YEAR & SOURCE TEXT & TARGET TEXT \\
\hline $\begin{array}{l}\text { Carne trémula } \\
\text { (1997) }\end{array}$ & $\begin{array}{l}\text {-Quiero llegar a ser el } \\
\text { mejor follador del } \\
\text { mundo, el mejor (Víctor) }\end{array}$ & $\begin{array}{l}\text { I want to become / } \\
\text { the best lover in the } \\
\text { world. }\end{array}$ \\
\hline
\end{tabular}

"Lover" does not convey the same vulgar meaning as "follador" does.

Víctor belongs to a lower social class; from the beginning of the film the source audience is aware of this because of his tone. The vulgar and dirty expressions that he uses should be kept in the target version, in order to preserve the personality and condition of the character. Víctor does not want to be "el mejor amante del mundo", but rather "el mejor follador del mundo". His register is, therefore, lost in the subtitles which contain euphemisms or neutralizations.

There is another expression that constantly appears in the films: "echar un polvo". According to dictionaries, there are several translations of this expression into English:

\begin{tabular}{|l|l|l|}
\hline FILM AND YEAR & SOURCE TEXT & TARGET TEXT \\
\hline iÁtame! (1990) & $\begin{array}{l}\text {-..y echamos un polvo } \\
\text { (Ricky) }\end{array}$ & ...and screwed. \\
\hline
\end{tabular}




\begin{tabular}{|c|c|c|}
\hline ¡Átame! (1990) & $\begin{array}{l}\text {-Oye ¿echamos un polvo } \\
\text { y me das } 5000 \text { pesetas? } \\
\text { (Drug-addict) }\end{array}$ & $\begin{array}{l}\text { You wanna fuck me / } \\
\text { for } 5000 \text { pesetas? }\end{array}$ \\
\hline ¡Átame! (1990) & $\begin{array}{l}\text {-No puedo ir yo por ahí } \\
\text { echando polvos (Ricky) }\end{array}$ & $\begin{array}{l}\text { I can't go around } \\
\text { fucking people. }\end{array}$ \\
\hline Kika (1993) & $\begin{array}{l}\text {-...pensando que iba a } \\
\text { echar un polvo (Kika) }\end{array}$ & $\begin{array}{l}\text {...thinking// } \\
\text {..I was going to get } \\
\text { laid. }\end{array}$ \\
\hline Kika (1993) & $\begin{array}{l}\text {-...me pegas un polvo } \\
\text { (Juana) }\end{array}$ & ...you screw me. \\
\hline $\begin{array}{l}\text { Tacones lejanos } \\
\text { (1991) }\end{array}$ & $\begin{array}{l}\text { - ¿Echamos un polvo o } \\
\text { me pongo la barba? } \\
\text { (Eduardo) }\end{array}$ & $\begin{array}{l}\text { How about a quickie / } \\
\text { before I put on my } \\
\text { beard? }\end{array}$ \\
\hline $\begin{array}{l}\text { Carne trémula } \\
\text { (1997) }\end{array}$ & $\begin{array}{l}\text {-iUn polvo de puta } \\
\text { madre! (Elena) }\end{array}$ & A great fuck? \\
\hline $\begin{array}{l}\text { Carne trémula } \\
\text { (1997) }\end{array}$ & $\begin{array}{l}\text {-...cuántos polvos habrás } \\
\text { tenido que echar (Víctor) }\end{array}$ & $\begin{array}{l}\text { How many tricks / } \\
\text { you had to turn. }\end{array}$ \\
\hline
\end{tabular}

There seems to be no consistency as far as the translation of this expression is concerned: "fuck", "screw", “quickie", "get laid” and "trick" are used throughout the translations. The translators have opted for other expressions that are appropriate, and that achieve the equivalent effect. However, the last example from Carne trémula does not really show the vulgarity of the original: "tricks" are really the clients of the prostitutes, and thus the term refers to people, rather than to the act itself. 
There is another synonym that appears in some of the dialogues: "tirarse", whose meaning would be "to lay" or "to screw". These examples show that there is no clear agreement on the translation, and yet all the TTs maintain the vulgarity level of the original:

\begin{tabular}{|l|l|l|}
\hline FILM AND YEAR & SOURCE TEXT & TARGET TEXT \\
\hline $\begin{array}{l}\text { Laberinto de } \\
\text { pasiones (1982) }\end{array}$ & $\begin{array}{l}\text {-¿Que no te lo has } \\
\text { 'tirao'? (Queti) }\end{array}$ & $\begin{array}{l}\text { You haven't screwed } \\
\text { him? }\end{array}$ \\
\hline $\begin{array}{l}\text { La ley del deseo } \\
\text { (1987) }\end{array}$ & $\begin{array}{l}\text {-¿No te la tirarías? } \\
\text { (Policeman 2) }\end{array}$ & $\begin{array}{l}\text { Wouldn't you liketo } \\
\text { lay her? }\end{array}$ \\
\hline Kika (1993) & $\begin{array}{l}\text {-Ramón, que me he } \\
\text { tirado a Nicholas de vez } \\
\text { en cuando (Kika) }\end{array}$ & $\begin{array}{l}\text { I fucked Nicholas once } \\
\text { in a while... }\end{array}$ \\
\hline $\begin{array}{l}\text { Carne trémula } \\
\text { (1997) }\end{array}$ & $\begin{array}{l}\text {-Y pensar que cualquiera } \\
\text { de estos gilipollas podría } \\
\text { ir a tirarse a mi mujer } \\
\text { mientras yo estoy } \\
\text { currando (Sancho) }\end{array}$ & $\begin{array}{l}\text { To think that any of } \\
\text { those creeps / } \\
\text { could go screw my } \\
\text { wife while I'm } \\
\text { working. }\end{array}$ \\
\hline $\begin{array}{l}\text { Todo sobre mi } \\
\text { madre (1999) }\end{array}$ & $\begin{array}{l}\text {-...tirándose todo lo que } \\
\text { pillaba...(Manuela) }\end{array}$ & $\begin{array}{l}\text { screwing everything he } \\
\text { could... }\end{array}$ \\
\hline
\end{tabular}

There is also an example taken from Laberinto de pasiones in which the verb "tirarse" appears. Yet, the translation displays a euphemism again: 


\begin{tabular}{|l|l|l|}
\hline FILM AND YEAR & SOURCE TEXT & TARGET TEXT \\
\hline $\begin{array}{l}\text { Laberinto de } \\
\text { pasiones (1982) }\end{array}$ & $\begin{array}{l}\text {-iQuiero tirarme a tu } \\
\text { padre! (Susana) }\end{array}$ & $\begin{array}{l}\text {...I want to sleep } \\
\text { with your father. }\end{array}$ \\
\hline
\end{tabular}

"Huevos" and "cojones" are two vulgar ways of referring to testicles; they are used in several colorful expressions also present in Almodóvar's films. The expressions "tener hasta los huevos" or "estar hasta los cojones", meaning "to be fed up" or "to be pissed off" - very unrefined - are translated by means of euphemisms:

\begin{tabular}{|l|l|l|}
\hline FILM AND YEAR & SOURCE TEXT & TARGET TEXT \\
\hline $\begin{array}{l}\text { Mujeres al borde } \\
\text { de un ataque de } \\
\text { nervios (1988) }\end{array}$ & $\begin{array}{l}\text {-Me tiene hasta los } \\
\text { huevos (Ana) }\end{array}$ & I'm fed up. \\
\hline $\begin{array}{l}\text { /Todo sobre mi } \\
\text { madre (1999) }\end{array}$ & $\begin{array}{l}\text {-iEstoy hasta los } \\
\text { cojones de veros a las } \\
\text { dos cuchicheando delante } \\
\text { de mis narices! } \\
\text { (Kowalski) }\end{array}$ & $\begin{array}{l}\text { I'm tired of you two } \\
\text { whispering / } \\
\text { under my nose all the } \\
\text { time! }\end{array}$ \\
\hline
\end{tabular}

Due to these euphemisms, the target spectator remains unaware of the rudeness expressed by these characters. By not preserving the original register, there is a loss in the translation. However, in the next example, the vulgarity is maintained, as "tocar los cojones de uno mismo" is translated as "not to give a shit": 


\begin{tabular}{|l|l|l|}
\hline FILM AND YEAR & SOURCE TEXT & TARGET TEXT \\
\hline $\begin{array}{l}\text { Carne trémula } \\
(1997)\end{array}$ & $\begin{array}{l}\text {-Me toca los cojones que } \\
\text { disparases por accidente } \\
\text { (David) }\end{array}$ & $\begin{array}{l}\text { I don't give a shit } \\
\text { if you fired by accident. }\end{array}$ \\
\hline
\end{tabular}

By way of threatening his interlocutor, the speaker talks of "arrancar los huevos de cuajo", the equivalent being "to rip somebody else's balls out/off":

\begin{tabular}{|l|l|l|}
\hline FILM AND YEAR & SOURCE TEXT & TARGET TEXT \\
\hline $\begin{array}{l}\text { Carne trémula } \\
\text { (1997) }\end{array}$ & $\begin{array}{l}\text {-iComo no sueltes a la } \\
\text { chica te voy a arrancar } \\
\text { los huevos de cuajo! } \\
\text { (Sancho) }\end{array}$ & $\begin{array}{l}\text { Let her go, / } \\
\text { or I'll rip your balls } \\
\text { off! }\end{array}$ \\
\hline $\begin{array}{l}\text { Carne trémula } \\
\text { (1997) }\end{array}$ & $\begin{array}{l}\text {-Debería haberte } \\
\text { arrancado los huevos } \\
\text { aquella noche (Sancho) }\end{array}$ & $\begin{array}{l}\text { I should have ripped / } \\
\text { your balls off that } \\
\text { night. }\end{array}$ \\
\hline
\end{tabular}

In jÁtame! Ricky manifests his masculinity by informing his interlocutor that he has "dos cojones". The following example displays its equivalent:

\begin{tabular}{|l|l|l|}
\hline FILM AND YEAR & SOURCE TEXT & TARGET TEXT \\
\hline iÁtame! (1990) & $\begin{array}{l}\text {-Pues con dos cojones } \\
\text { (Ricky) }\end{array}$ & I've got balls. \\
\hline
\end{tabular}


As seen above, "huevos" and "cojones" are vulgar synonyms for testicles, "balls" being their most adequate translation ${ }^{31}$ :

\begin{tabular}{|l|l|l|}
\hline FILM AND YEAR & SOURCE TEXT & TARGET TEXT \\
\hline $\begin{array}{l}\text { Carne trémula } \\
(1997)\end{array}$ & $\begin{array}{l}\text {-Pero que ése deje de } \\
\text { apuntarme a los huevos } \\
\text { (Víctor) }\end{array}$ & $\begin{array}{l}\text { All right, but tell him / } \\
\text { to stop aiming at my } \\
\text { balls }\end{array}$ \\
\hline
\end{tabular}

As regards vulgar language concerning sexual and bodily functions, the subtitles for the most part exhibit close equivalents in English, thus preserving the original flavor of these films in the translations. On the other hand, the omissions of some of these words and expressions may simply be explained by repetition: the over-use of the same word may have led the translators to omit them sometimes. Euphemisms are sometimes used to soften the vulgarity of the original. These two strategies, omissions and euphemisms, threaten the preservation of the film's identity and spirit. The instances that show a more vulgar translation than that of the ST are the exception, rather than the rule, to the general strategies followed by these translators.

\subsubsection{Expressions Concerning Rural Life}

As previously mentioned, Almodóvar was born in a small village in Castilla La Mancha, in the central part of Spain. In some of his films he recreates that rural atmosphere by means of certain characters who

\footnotetext{
${ }^{31}$ I recommend a reading of Arturo Perez Reverte's article about the richness of the word "cojones" in Spanish ("Cuestión de cojones" El Semanal, 26/04/98)
} 
tend to embody wisdom, who give solace to those who have problems, and whose language is full of "earthy phrases" (Allinson 2001: 43).

In some of his films Almodóvar gives his own mother, doña Paquita, a small role, as in ¿Qué he hecho yo para merecer esto?, in ¡Átame!, and in Kika. She always represents an old woman born and raised in the country, but now living in Madrid. Her words are full of advice, and she comforts other characters. The actress Chus Lampreave also appears, together with doña Paquita, in some of his movies. Every comment she makes and every scene she appears in is a humorous one in the film. Lampreave always plays the role of an old rural woman like doña Paquita. In ¿Qué he hecho yo para merecer esto? and in La flor de mi secreto, she plays an old woman who lives in Madrid with her daughter, but who constantly wishes to go back to the countryside since she does not enjoy living in Madrid. Like doña Paquita, she plays a character who helps people overcome their problems.

In ¿Qué he hecho yo para merecer esto?, Doña Paquita has a small role in which she plays an old woman from the same village as Gloria's mother-in-law. When the protagonist Gloria goes to the dentist with her son, she meets Doña Paquita in the waiting room. She recognizes Gloria, but Gloria does not remember her until Doña Paquita introduces herself. Then she talks about Gloria's childhood in the village:

\begin{tabular}{|l|l|l|}
\hline FILM AND YEAR & SOURCE TEXT & TARGET TEXT \\
\hline $\begin{array}{l}\text { ¿Qué he hecho yo } \\
\text { para merecer } \\
\text { esto?(1984) }\end{array}$ & $\begin{array}{l}\text {-¡Cuántas veces me has } \\
\text { 'meao' el mandil, hija } \\
\text { mía! (Doña Paquita) }\end{array}$ & $\begin{array}{l}\text { The times you wetted } \\
\text { my } \\
\text { apron... }\end{array}$ \\
\hline
\end{tabular}


This is a very rural comment that recalls one's childhood, and the vocative "hija mía" with which doña Paquita tenderly addresses Gloria is especially common in rural places. Even though the subtitles adequately transmit the original idea (to wet an apron), they cannot preserve the rural feeling; nor do they translate the vocative. Later on in the same film, doña Paquita meets Gloria's mother-in-law at the open-air bus station. They are very happy to see each other, and to go back to their village. As they start talking about how things are going, the first question Paca asks is how many people have died in their village, to which Doña Paquita replies:

\begin{tabular}{|l|l|l|}
\hline FILM AND YEAR & SOURCE TEXT & TARGET TEXT \\
\hline $\begin{array}{l}\text { ¿Qué he hecho yo } \\
\text { para merecer esto? } \\
\text { (1984) }\end{array}$ & $\begin{array}{l}\text {-Se muere mucha gente. } \\
\text { No queda un viejo (Doña } \\
\text { Paquita) }\end{array}$ & $\begin{array}{l}\text { All the old ones are } \\
\text { dying... }\end{array}$ \\
\hline
\end{tabular}

Paca is really sorry, but doña Paquita says:

\begin{tabular}{|l|l|l|}
\hline FILM AND YEAR & SOURCE TEXT & TARGET TEXT \\
\hline $\begin{array}{l}\text { ¿Qué he hecho yo } \\
\text { para merecer esto? } \\
\text { (1984) }\end{array}$ & $\begin{array}{l}\text {-Pero lo que es menester } \\
\text { es que pare ahí, en los } \\
\text { viejos, que no se lleve los } \\
\text { jóvenes (Doña Paquita) }\end{array}$ & $\begin{array}{l}\text { Better for the old ones } \\
\text { to die....// } \\
\text {...than the young ones. }\end{array}$ \\
\hline
\end{tabular}

There is nothing more representative of rural life than this comment by doña Paquita. The expression "es menester" is part of the rural language that people from towns and cities are not used to. But this rural flavor is not kept in the TT, for no direct translation is possible. Thus the rural 
register of doña Paquita is lost in the translation. The standardization of the translation results in the neutralization of certain linguistic elements associated with rural speech. The standardization of the TT also implies an incomplete and distorted image of the character.

In the same film Chus Lampreave - Paca - plays the role of a rural grandmother who goes to Madrid to live with her son and his family. Even though ¿Qué he hecho yo para merecer esto? is about the hard life of a low class family, and all the problems they have to overcome daily, Lampreave gives a brushstroke of humor to the film. She has a good relationship with her grandson Tony, a teenage drug-dealer who does not want to go to school. Not only does his grandmother understand and support his decision, but their relationship is so good that they even hang out together. It is really amusing to see Tony with his grandmother, still in mourning after so many years, going to a bar together, or spending the afternoon out. But the most humorous thing about Paca is her language. The speech of Tony, the young drug-dealer from a lower-class family is full of slang, a slang from the 80 s and the "city's subculture" (Allinson 2001: 44). This slang is called "Cheli", and it originated in the Madrid "movida" filtering through conversational registers of the Spanish language, and giving new meanings to basic words. Nowadays it is still in use by some speakers. What is so humorous is that Paca adopts her grandson's slang. There are several scenes that illustrate this special use of language, like the following one that takes place when she drinks sparkling water:

\begin{tabular}{|l|l|l|}
\hline FILM AND YEAR & SOURCE TEXT & TARGET TEXT \\
\hline $\begin{array}{l}\text { ¿Qué he hecho yo } \\
\text { para merecer esto? } \\
(1984)\end{array}$ & $\begin{array}{l}\text {-¡Ay cómo flipo con las } \\
\text { burbujas! (Grandmother) }\end{array}$ & $\begin{array}{l}\text { Bubbles sure make me } \\
\text { flip! }\end{array}$ \\
\hline
\end{tabular}




\begin{tabular}{|l|l|l|}
\hline & & \\
\hline & $\begin{array}{l}\text {-¿A ti no te enrollan? } \\
\text { (Grandmother) }\end{array}$ & Don’t you dig them? \\
\hline
\end{tabular}

In the first example, the verb "flipar" ("to have a great time") has been translated as "to flip". However, the meaning of the informal use of this verb is "to become extremely upset or angry because of something that has happened". Unable to render the exact meaning of the original, the translator has included a "false friend"; perhaps, then, this is a case of a simple error. In the second example, the verb "enrollar" which means "to like" has been rendered as "to dig", to maintain the meaning and informality of the original. These examples try to convey the slang of the original by introducing two informal verbs. Also when Cristal, their prostitute neighbor, knocks on the door to ask for Gloria, Paca excuses herself for not letting her in:

\begin{tabular}{|l|l|l|}
\hline FILM AND YEAR & SOURCE TEXT & TARGET TEXT \\
\hline $\begin{array}{l}\text { ¿Qué he hecho yo } \\
\text { para merecer esto? } \\
(1984)\end{array}$ & $\begin{array}{l}\text {-No te digo que entres } \\
\text { porque estoy enrollada } \\
\text { con el punto } \\
\text { (Grandmother) }\end{array}$ & $\begin{array}{l}\text { I can't ask you in } \\
\text { 'cause/ I'm swamped } \\
\text { with my knitting... }\end{array}$ \\
\hline & $\begin{array}{l}\text {-Mira, paso total de } \\
\text { vosotras. Me aburrís } \\
\text { (Grandmother) }\end{array}$ & $\begin{array}{l}\text { I don't give a shit, } \\
\text { you bore me... }\end{array}$ \\
\hline & $\begin{array}{l}\text {-Paso total } \\
\text { (Grandmother) }\end{array}$ & You're out of it. \\
\hline
\end{tabular}


In the first example "estar enrollado/a" means "to be into something". Nevertheless, the subtitles display the expression "to be swamped", which means "to have more things than you can deal with". In other words, the TT here does not achieve the equivalent effect. The translation of the second example is extremely rude in comparison with the original expression, "paso total". Literally it means "I ignore you", instead of the unnecessarily vulgar expression, "I don't give a shit". In the third of these examples the TT again displays another inaccurate expression: "paso total" as said above means "I ignore you". Instead, the subtitles introduce "you are out of it", which means "to be intoxicated due to drink or drugs". In the TT, instead of ignoring the addressee as in the ST, Paca is insulting her by accusing her of being intoxicated.

Comments which accurately render the distinctive register of the speaker can also be found:

\begin{tabular}{|l|l|l|}
\hline FILM AND YEAR & SOURCE TEXT & TARGET TEXT \\
\hline $\begin{array}{l}\text { ¿Qué he hecho yo } \\
\text { para merecer esto? } \\
(1984)\end{array}$ & $\begin{array}{l}\text {-¡Dabuti, tío! } \\
\text { (Grandmother) }\end{array}$ & Right on, man! \\
\hline
\end{tabular}

This bizarre grandmother is especially tight-fisted. Her son and family are miserably poor, and sometimes don't even have anything to eat, but she keeps pastry and sparkling water locked in her room, and doesn't share her food with the family members who take care of her. In one scene Gloria gives her sexist husband, Antonio, a small chicken for dinner. Paca asks him to leave her the skin and bones so she can lick them for dessert. Although this moment shows the poverty they live in, it is Paca's character that makes it humorous. Even more comical are the 
comments she makes on how smelly her son's feet are. The hilarity of this comment lies in the tone in which she speaks:

\begin{tabular}{|l|l|l|}
\hline FILM AND YEAR & SOURCE TEXT & TARGET TEXT \\
\hline $\begin{array}{l}\text { ¿Qué he hecho yo } \\
\text { para merecer esto? } \\
\text { (1984) }\end{array}$ & $\begin{array}{l}\text {-En los pies has salido } \\
\text { entero a tu padre. Cuando } \\
\text { te descalzas...te huelen } \\
\text { igual, igual que a él. Un } \\
\text { olor intenso, fuerte. Yo } \\
\text { casi no puedo respirar } \\
\text { (Grandmother) }\end{array}$ & $\begin{array}{l}\text { Your feet are just like } \\
\text { your father's...// } \\
\text { The same smell, strong, } \\
\text { powerful...// } \\
\text { I can hardly breathe... }\end{array}$ \\
\hline
\end{tabular}

Besides, even though Paca does not share her food with her son, she constantly shows her admiration and love for him. At one point, when her son burps loudly in front of her, she replies:

\begin{tabular}{|l|l|l|}
\hline FILM AND YEAR & SOURCE TEXT & TARGET TEXT \\
\hline $\begin{array}{l}\text { ¿Qué he hecho yo } \\
\text { para merecer esto? } \\
\text { (1984) }\end{array}$ & $\begin{array}{l}\text {-¡Olé mi niño! } \\
\text { (Grandmother) }\end{array}$ & Bless you! \\
\hline
\end{tabular}

Yet that mixture of love and tenderness in the original comment is not kept in the translation: "olé" is a cultural exclamation in Spanish, and finding an equivalent in English is impossible. Instead, the translator has opted for as uncommon a reaction to this body function, since "bless you" is the appropriate exclamation when someone sneezes.

Elderly rural people tend to use a language that reflects a high degree of religiosity. Besides the influence of "Cheli" on Paca's idiolect, 
her interventions are full of religious sayings and superstitions. San Antonio is said to help people find lost things, and people resort to Santa Bárbara whenever there is a storm:

\begin{tabular}{|l|l|l|}
\hline FILM AND YEAR & SOURCE TEXT & TARGET TEXT \\
\hline $\begin{array}{l}\text { ¿Qué he hecho yo } \\
\text { para merecer esto? } \\
\text { (1984) }\end{array}$ & $\begin{array}{l}\text {-Me encomendaré a San } \\
\text { Antonio. Él lo encontrará } \\
\text { (Grandmother) }\end{array}$ & $\begin{array}{l}\text { I'll ask Saint Anthony } \\
\text { to find it. }\end{array}$ \\
\hline & $\begin{array}{l}\text {-No sé dónde tienes la } \\
\text { cabeza. Tendré que } \\
\text { recurrir a San Antonio } \\
\text { otra vez. A ver qué voy a } \\
\text { hacer... (Grandmother) }\end{array}$ & $\begin{array}{l}\text { I have no choice but to } \\
\text { ask St. Anthony to } \\
\text { find it... }\end{array}$ \\
\hline & $\begin{array}{l}\text { - ¡Uy, que relámpago! } \\
\text { ¡Santa Bárbara } \\
\text { bendita! (Grandmother) }\end{array}$ & Holy Barbara! What a \\
& \multicolumn{1}{l}{ lightning flash. } \\
\hline
\end{tabular}

The translator has decided to maintain the source Catholic references in the translation, and has faithfully reproduced the Spanish cultural context. By reflecting the linguistic and cultural values of the ST, the translation maintains the film's original flavor, but at the same time, this can create problems for the target audience who may not be familiar with Catholic figures and traditions.

Matador is another film in which rural life is present. The character of Pilar, played by Lampreave again, utters those earthy phrases so characteristic of the countryside. She plays the mother of Eva, a woman who has been raped, and even though her daughter is a grown 
up and has her own private life, Pilar is an overprotective mother who is always taking care of her daughter. She is very talkative, and every time she talks she generates a new funny scene. In one scene, two policemen go to her house to interview Eva about her rape experience. Eva replies in an aggressive way, and her mother agrees:

\begin{tabular}{|l|l|l|}
\hline FILM AND YEAR & SOURCE TEXT & TARGET TEXT \\
\hline Matador (1986) & $\begin{array}{l}-¡ \text { Y como vuelva a } \\
\text { ponerme las manos } \\
\text { encima, le castro! (Eva) }\end{array}$ & $\begin{array}{l}\text { And if he tries again, } \\
\text { I'll cut his balls off! }\end{array}$ \\
\hline
\end{tabular}

This example displays a more vulgar expression in the subtitles: while "castrar" is a formal verb meaning "to castrate": "to cut somebody's balls off' is stronger and more vulgar in meaning.

The two policemen insist on taking Pilar and Eva to the police station:

\begin{tabular}{|l|l|l|}
\hline FILM AND YEAR & SOURCE TEXT & TARGET TEXT \\
\hline Matador (1986) & $\begin{array}{l}\text {-Pero, ¡cómo quiere que } \\
\text { vayamos con usted } \\
\text { teniendo la casa manga } \\
\text { por hombro como la } \\
\text { tenemos! Mire estoy } \\
\text { blanqueando y estoy } \\
\text { haciéndolo sola porque } \\
\text { no tengo a nadie quien } \\
\text { me ayude (Pilar) }\end{array}$ & The place is a mess...// \\
\hline
\end{tabular}

Pilar complains about her condition to the policemen. Once again, the colloquial Spanish in the speech of the character is not transmitted in the 
subtitles, which talk about the state of the house in a neutral way. Meanwhile, Pilar keeps on groaning:

\begin{tabular}{|l|l|l|}
\hline FILM AND YEAR & SOURCE TEXT & TARGET TEXT \\
\hline Matador (1986) & $\begin{array}{l}\text {-Por si fuera poco que la } \\
\text { casa esté } \\
\text { empantanada...(Pilar) }\end{array}$ & :.:.:.:.:.:: \\
\hline & $\begin{array}{l}\text {-No insista señora. } \\
\text { Cállese (Policeman II) }\end{array}$ & Be quiet! \\
\hline & $\begin{array}{l}\text {-iNo me chille porque le } \\
\text { puedo meter un } \\
\text { paquete...! (Pilar) }\end{array}$ & $\begin{array}{l}\text { Don’t start with me...../ } \\
\text {...or you'll be in trouble! }\end{array}$ \\
\hline
\end{tabular}

In the first example there is a complete omission of the ST. Pilar is again complaining about the condition of her house, which implies how stupid she is: her daughter has been raped, and she says she can't go to the police station because her house is a mess. The target spectator is thus deprived of an opportunity to see the absurdity of this situation. Her second intervention with the colloquial expression in the ST, "meter un paquete", has been translated as to "be in trouble", which certainly reflects the meaning, but not the register. Finally, she agrees to go to the police station, but on condition that they dress properly:

\begin{tabular}{|l|l|l|}
\hline FILM AND YEAR & SOURCE TEXT & TARGET TEXT \\
\hline Matador (1986) & $\begin{array}{l}\text {-Porque ¿no querrán que } \\
\text { vayamos hechas unos } \\
\text { mamarrachos a toda una } \\
\text { señora comisaría? (Pilar) }\end{array}$ & $\begin{array}{l}\text { You don’t want us to } \\
\text { go } \\
\text { to the station...// } \\
\text {...looking a sight. }\end{array}$ \\
& & \\
\hline
\end{tabular}


Here the subtitles have successfully transmitted the original expression "estar hechas unos mamarrachos" by means of "to look a sight". Both ST and TT mean "to look untidy or ridiculous". Nevertheless, the humor of the source expression with the word "mamarrachos" is not kept in the translation, as there is no direct equivalent in English. Besides, the adjective "señora" that modifies the word "comisaría" ("station") has been omitted in the TT. By means of this adjective so characteristic of a rural register Pilar is giving her opinion about the station. Better to have translated "a toda una señora comisaría" with "to such a great big station", in order to emphasize the respect Pilar shows towards the police force. Unfortunately, this is neutralized in the translation.

Once at the police station it is Pilar who talks instead of her

\section{daughter:}

\begin{tabular}{|l|l|l|}
\hline FILM AND YEAR & SOURCE TEXT & TARGET TEXT \\
\hline Matador (1986) & $\begin{array}{l}\text {-Lo peor no es que te } \\
\text { violen. Es que lo tienes } \\
\text { que contar 'de 'p' a } \\
\text { 'pa's a todo el mundo } \\
\text { (Pilar) }\end{array}$ & $\begin{array}{l}\text { What's worst than } \\
\text { getting raped// } \\
\text {...is having to tell } \\
\text { everyone about it. }\end{array}$ \\
\hline
\end{tabular}

Again, the colloquial expression "contar de 'p' a 'pa"' ("to tell something with a wealth of detail") is omitted in the translation, thus losing the register characteristic of the original. Pilar continues addressing the policeman in a very natural way:

\begin{tabular}{|l|l|l|}
\hline FILM AND YEAR & SOURCE TEXT & TARGET TEXT \\
\hline Matador (1986) & $\begin{array}{l}\text {-Le agradecería que fuera } \\
\text { al grano (Pilar) }\end{array}$ & Get to the point. \\
\hline
\end{tabular}


Here, the source colloquial expression is translated by means of its equivalent. The policeman wants to know every single detail of the rape, so it is suggested that Pilar leave the room to keep her from collapsing. But she refuses:

\begin{tabular}{|l|l|l|}
\hline FILM AND YEAR & SOURCE TEXT & TARGET TEXT \\
\hline Matador (1986) & $\begin{array}{l}\text {-Desde luego no es plato } \\
\text { de gusto. Pero ya no soy } \\
\text { una niña (Pilar) }\end{array}$ & $\begin{array}{l}\text { It isn't, but I wasn't } \\
\text { born yesterday.... }\end{array}$ \\
\hline
\end{tabular}

In this example the translation does not achieve the equivalent effect. The expression "no ser plato de gusto" has an equivalent expression in English that is "not to be one's cup of tea". However, the translator has not resorted to this colloquialism. Later in the film Pilar goes to a fashion show where Eva works. Montesinos, the designer - played by Almodóvar himself - gives Eva what is supposed to be a wedding dress, to which Pilar replies:

\begin{tabular}{|l|l|l|}
\hline FILM AND YEAR & SOURCE TEXT & TARGET TEXT \\
\hline Matador (1986) & $\begin{array}{l}\text {-Desde luego, si esto es } \\
\text { un vestido de novia, que } \\
\text { venga Dios y lo vea } \\
\text { (Pilar) }\end{array}$ & $\begin{array}{l}\text { If that's a wedding dress, } \\
\text { my name's Jim. }\end{array}$ \\
\hline
\end{tabular}


Here again Pilar makes use of religious terms. But "que venga Dios y lo vea" is translated as "my name's Jim", an acceptable translation that makes sense to the target audience, but it does not involve God.

When Pilar sees María Cardenal, a famous lawyer, at the fashion show she says frankly:

\begin{tabular}{|l|l|l|}
\hline FILM AND YEAR & SOURCE TEXT & TARGET TEXT \\
\hline Matador (1986) & $\begin{array}{l}\text {-La encuentro un poco } \\
\text { putón (Pilar) }\end{array}$ & $\begin{array}{l}\text { She looks a bit } \\
\text { whorish.... }\end{array}$ \\
\hline & $\begin{array}{l}\text {-Reconozco que es } \\
\text { mona. Lo mismo que te } \\
\text { digo una cosa, te digo la } \\
\text { otra (Pilar) }\end{array}$ & $\begin{array}{l}\text {...pretty, but then, one } \\
\text { goes with the other. }\end{array}$ \\
\hline & $\begin{array}{l}\text {-Todo el tufo de esto no } \\
\text { me gusta nada (Pilar) }\end{array}$ & $\begin{array}{l}\text { There's a rotten smell } \\
\text { to this.... }\end{array}$ \\
\hline
\end{tabular}

The first and third examples display an equivalent expression in the translation, but the register of second example is not successfully transmitted.

Eva's boyfriend Diego, a retired bullfighter, finally breaks up with Eva, who becomes desperate and depressed. Pilar suffers for her daughter and suggests that she ignore him:

\begin{tabular}{|l|l|l|}
\hline FILM AND YEAR & SOURCE TEXT & TARGET TEXT \\
\hline Matador (1986) & $\begin{array}{l}\text {-Te encuentro un poco } \\
\text { 'p'allá (Pilar) }\end{array}$ & $\begin{array}{l}\text { You're a bit out of it, } \\
\text { Eva. }\end{array}$ \\
\hline & -...pasa de él (Pilar) & $\ldots . . j u s t$ forget him. \\
\hline
\end{tabular}


\begin{tabular}{|l|l|l|}
\hline & & \\
\hline
\end{tabular}

The translation of the first example does not succeed in keeping the register of the $S T$, as it is impossible to find a close natural equivalent for it. But the second example does display an equivalent. Seeing that her daughter is not happy, Pilar expresses her own suffering:

\begin{tabular}{|l|l|l|}
\hline FILM AND YEAR & SOURCE TEXT & TARGET TEXT \\
\hline Matador (1986) & $\begin{array}{l}\text {-¡Cuántas sofocaciones } \\
\text { me das, hija mía, } \\
\text { cuántas! (Pilar) }\end{array}$ & $\begin{array}{l}\text { What can a poor } \\
\text { mother do? }\end{array}$ \\
\hline
\end{tabular}

Once again the register of the source expression is lost in the subtitles, which just exhibit a synopsis of Pilar's feelings, losing any trace of either the colloquial and the humorous comment.

In Mujeres Lampreave also plays a small role. Here she plays a Jehova's witness janitor, and is in charge of transmitting Pepa's messages to Iván. Her comments are extraordinarily hilarious. Iván does not want to see Pepa, since he is leaving her because of another woman. Pepa is supposed to leave his suitcase with the janitor, but she does not do so as she wants to talk to Iván personally. He in turn calls the janitor to check if she has the suitcase, and begs her not to tell Pepa about his visit. The janitor replies:

\begin{tabular}{|l|l|l|}
\hline FILM AND YEAR & SOURCE TEXT & TARGET TEXT \\
\hline $\begin{array}{l}\text { Mujeres al borde } \\
\text { de un ataque de } \\
\text { nervios (1988) }\end{array}$ & $\begin{array}{l}\text {-Lo siento señorito, pero } \\
\text { yo mi religión me prohibe } \\
\text { mentir (Janitor) }\end{array}$ & $\begin{array}{l}\text { Sir. I'm a Jehovah's } \\
\text { witness / } \\
\text { and cannot tell lies. }\end{array}$ \\
\hline
\end{tabular}


The subtitles here reflect the exact meaning of the original; nevertheless there are many cultural references in the ST that convey the humor of this speech. In order to react in the same way as the source spectator, the target audience should be aware that there are few Jehova's witnesses in Spain, and that Catholics tend to reject them. Trying to get people to convert, they knock on doors to say that the day of the doom is coming, and that only Jehova's witnesses are going to be saved. It is religion taken to the extreme. The janitor even uses the feminine of "testigo", which sounds really comical, and expresses the prohibition to lie. Iván does not expect this response, and again begs the janitor not to tell Pepa the truth, to which she says:

\begin{tabular}{|l|l|l|}
\hline FILM AND YEAR & SOURCE TEXT & TARGET TEXT \\
\hline $\begin{array}{l}\text { Mujeres al borde } \\
\text { de un ataque de } \\
\text { nervios (1988) }\end{array}$ & $\begin{array}{l}\text {-Pero si me pregunta lo } \\
\text { tendré que contar todo } \\
\text { con pelos y señales. Eso } \\
\text { es lo malo de las testigas, } \\
\text { que no podemos (Janitor) }\end{array}$ & $\begin{array}{l}\text { If she asks I have to } \\
\text { tell the gospel truth. } \\
\text { The bad thing about } \\
\text { my religion is...// } \\
\text {...that we can't. }\end{array}$ \\
\hline & $\begin{array}{l}\text {-Si no, aquí iba a estar } \\
\text { yo.jBah! (Janitor) }\end{array}$ & :.:.:.:.:.:: \\
\hline
\end{tabular}

The janitor's answers are completely unexpected: as a Jehova's witness she is forbidden to tell lies; so if Pepa asks her something, she will have to tell it as it is. What she does not like about her religion is that she cannot lie. Even though the subtitles of the first example faithfully recreate the source message, any trace of the humor of the original is lost because of the cultural gap between source and target cultures. She finishes with "si no, aquí iba a estar yo", meaning that if she were not a 
Jehova's witness, she would not be there. But the translator has omitted this sentence, thus depriving the target audience of its comicality.

Doña Paquita has a small role in jÁtame! too. She plays Marina's (Victoria Abril) mother. Marina is kidnapped by Ricky and kept tied up in her own house, but everybody thinks she went away without having said anything. Bothered by Marina's desperation, Ricky allows her to make a phone call. A porno actress, Marina has led a life of drugs, sex and all kind of vices. But when she calls her mother her face changes, and she looks like a little girl; she even bursts into tears when her mother picks up the phone. Doña Paquita is cooking in the kitchen; with her is one of her granddaughters who is touching the food, which upsets doña Paquita:

\begin{tabular}{|l|l|l|}
\hline FILM AND YEAR & SOURCE TEXT & TARGET TEXT \\
\hline ¡Átame! (1990) & $\begin{array}{l}\text {-iQué manera de } \\
\text { sobarlo! ¡Cojones! } \\
\text { (Doña Paquita) }\end{array}$ & $\begin{array}{l}\text { Don't mess with it! } \\
\text { Damn! }\end{array}$ \\
\hline
\end{tabular}

The source expression "que manera de sobarlo" is translated with a different expression that does not carry the register of the original. Besides, doña Paquita shows her bad-temper at her granddaughter and swears. Swearing is common with elderly country people; in that sense it could be said that old people in cities are more "refined". While she says "cojones", the subtitles display a softer exclamation "damn".

The granddaughter keeps on bothering her grandma, and she shouts again: 


\begin{tabular}{|l|l|l|}
\hline iÁtame! (1990) & $\begin{array}{l}- \text { iCuidado que niña! } \\
\text { (Doña Paquita) }\end{array}$ & What a brat! \\
\hline
\end{tabular}

The equivalent effect is produced in the subtitles by means of "what a brat!". Marina asks her mother what she is cooking:

\begin{tabular}{|l|l|l|}
\hline FILM AND YEAR & SOURCE TEXT & TARGET TEXT \\
\hline iÁtame! (1990) & $\begin{array}{l}\text {-¿Qué hay? Pues pisto } \\
\text { (Doña Paquita) }\end{array}$ & It's “pisto”. \\
\hline
\end{tabular}

The translator has decided not to translate the name of this Spanish dish of peppers, zucchini, onions, eggs and olive oil, as the subtitle keeps its Spanish name in inverted comas. This insertion of a cultural nonequivalent, or the actual SL word, in the translation may indicate that its meaning is not essential to the understanding of the film's content. At the same time, maintaining the source references enhances the value of the film's cultural identity. Marina seems to black out at the sound of the word "pisto" and she would like to have some. Doña Paquita offers to put some in the freezer so she can pick it up later. The image of mothers preparing food for their children is one that is deeply rooted in Spanish culture, so the target spectator may not understand Marina's insistence on knowing what her mother has cooked. When Marina has to hang up, Doña Paquita replies “don't forget me”, so Marina says good-bye and starts sobbing again. Her conversation with her mother has made her realize how important she is for her. Indeed, Almodóvar was very close to his mother, which is the reason he repeatedly includes a mother figure 
in his films. Doña Paquita embodies both the rural life that has no place in the city as well as the importance of the family.

Kika is the last film in which Doña Paquita appears. She is the hostess of a TV program entitled "Hay que leer más", translated as "Let's read more". She has to interview Nicholas, an American writer who lives in Spain. She expresses her difficulty in pronouncing foreign names and offers him some "chorizo":

\begin{tabular}{|l|l|l|}
\hline FILM AND YEAR & SOURCE TEXT & TARGET TEXT \\
\hline Kika $(1993)$ & $\begin{array}{l}\text {-Cómase un choricillo } \\
\text { (Doña Paquita) }\end{array}$ & Have some chorizo. \\
\hline
\end{tabular}

The translator has here included a cultural non-equivalent probably because it is irrelevant in terms of the action, and yet enriching for the target culture. The absurdity of this comment lies in the fact that it is unusual to find a TV program on literature in which the hostess is an old woman who offers food to her guests. Nicholas refuses but she insists:

\begin{tabular}{|l|l|l|}
\hline FILM AND YEAR & SOURCE TEXT & TARGET TEXT \\
\hline Kika $(1993)$ & $\begin{array}{l}\text {-Son manchegos, como } \\
\text { yo. Están muy ricos } \\
\text { (Doña Paquita) }\end{array}$ & $\begin{array}{l}\text { It's from La } \\
\text { Mancha, like me. } \\
\text { It's delicious! }\end{array}$ \\
\hline
\end{tabular}

Doña Paquita says that she is from La Mancha just like the 'chorizos'. The subtitle reflects the name of the region, not the name of the inhabitants "manchegos" related to the "chorizo". Of course, it is more comprehensible for the audience to read the name of the region instead of the name of its inhabitants or its products. Then they talk about Nicholas' 
recently published book, and she frankly says that she is not going to read it. This is a funny thing to say to her host, and her frankness is surprising.

The various short comments made by these characters can be seen as symbols of Almodóvar's rural origins. The love he has always had for his mother persuaded her to play small roles in some of his films. Thus the characters played by Lampreave and doña Paquita embody the wisdom of the older generation, and give brushstrokes of comicality to the storyline. In this way they build their private microcosms. The language of these characters is full of "earthy phrases" that symbolize their life experiences, and their mission is to give advice and understanding to their loved ones. Every time they utter a word, they come up with a natural humorous comment. Their language has a natural flow that produces hilarious effects and reflects maturity and wisdom.

However, these characters lack originality and humor in the translations. Achieving the equivalent effect is usually impossible because of the non-nexistence of an equivalent register in English, and the difficulty of reflecting it in the subtitles. On balance, the translations usually convey the original message but are unable to produce the same effect as the ST. The register is completely lost, together with all trace of humor. Some subtitles display incongruities, as if the translators were not aware of the real meaning of the expression. Others exhibit cultural nonequivalents that preserve the film's cultural identity and enrich the target culture.

\subsubsection{Swearing}


Swearing is much more common in Spain than in many other Western nations, and this is also reflected in Almodóvar. (Allinson 2001: 43)

Of all the swear words in Spanish, "joder" could be said to be the most common one of them all, its equivalent in English being "fuck". Spanish also makes use of synonyms of both male and female genitals in order to express anger, surprise or disappointment - "coño" ("cunt"), “cojones" ("balls") -, as well as the word "mierda" ("shit").

In Almodóvar's films there are numerous examples in which "joder" appears, and "fuck" seems to be its closest translation:

\begin{tabular}{|l|l|l|}
\hline FILM AND YEAR & SOURCE TEXT & TARGET TEXT \\
\hline Matador (1986) & -¡Joder! (Diego) & Fuck! \\
\hline $\begin{array}{l}\text { Carne trémula } \\
\text { (1997) }\end{array}$ & -¡Joder! (Driver) & Fuck! \\
\hline $\begin{array}{l}\text { Carne trémula } \\
\text { (1997) }\end{array}$ & -¡Joder! (Sancho) & Fuck! \\
\hline $\begin{array}{l}\text { Carne trémula } \\
\text { (1997) }\end{array}$ & $\begin{array}{l}\text {-¡Perdóname, joder! } \\
\text { (Sancho) }\end{array}$ & Fuck, forgive me! \\
\hline $\begin{array}{l}\text { Todo sobre mi } \\
\text { madre (1999) }\end{array}$ & $\begin{array}{l}\text {-¡Joder, el bolso! } \\
\text { (Manuela) }\end{array}$ & Fuck, my purse! \\
\hline $\begin{array}{l}\text { Todo sobre mi } \\
\text { madre (1999) }\end{array}$ & \begin{tabular}{l}
-¡Joder! (Mario) \\
\hline
\end{tabular} & Fuck! \\
\hline
\end{tabular}




\begin{tabular}{|l|l|l|}
\hline $\begin{array}{l}\text { ¿Qué he hecho yo } \\
\text { para merecer esto? } \\
(1984)\end{array}$ & -¡Joder! (Antonio) & Fuck! \\
\hline
\end{tabular}

All these subtitles contain the vulgarity of the original, and preserve the register of the individual speakers.

At other times the translator(s) opt(s) for the word "Christ" or even "God", giving a religious connotation to the original swear word:

\begin{tabular}{|l|l|l|}
\hline FILM AND YEAR & SOURCE TEXT & TARGET TEXT \\
\hline $\begin{array}{l}\text { ¿Qué he hecho yo } \\
\text { para merecer esto? } \\
\text { (1984) }\end{array}$ & $\begin{array}{l}\text {-¡Joder, qué vicio tienes } \\
\text { con peinarme, abuela! } \\
\text { (Tony) }\end{array}$ & $\begin{array}{l}\text { Christ, grandma! } \\
\text { You're } \\
\text { hooked! }\end{array}$ \\
\hline $\begin{array}{l}\text { Mujeres al borde } \\
\text { de un ataque de } \\
\text { nervios (1988) }\end{array}$ & -¡Joder! (Candela) & Christ! \\
\hline $\begin{array}{l}\text { iAtame! (1990) } \\
\text { iÁtame! (1990) }\end{array}$ & -¡jJoder! (Ricky) & Christ! \\
\hline Matador (1986) & -¡Joder! (Doctor) & Christ! \\
\hline
\end{tabular}

While "Christ" is as vulgar as the ST word "joder", "God" is not as offensive, since it is a expression used in exclamations for emphasis or to express surprise, fear, shock, or excitement.

"Shit" as well as "damn" can also be found in several examples as translations of "joder": 


\begin{tabular}{|l|l|l|}
\hline FILM AND YEAR & SOURCE TEXT & TARGET TEXT \\
\hline ¡Átame! (1990) & -¡Joder! (Ricky) & Damn! \\
\hline ¡Átame! (1990) & $\begin{array}{l}\text {-¡Qué putada, joder! } \\
\text { (Ricky) }\end{array}$ & Damn! \\
\hline $\begin{array}{l}\text { Tacones lejanos } \\
\text { (1991) }\end{array}$ & -¡Joder! (Eduardo) & Shit! \\
\hline $\begin{array}{l}\text { Carne trémula } \\
\text { (1997) }\end{array}$ & $\begin{array}{l}\text {-¡Venga tío, Sancho, } \\
\text { joder! (David) }\end{array}$ & Cool it, Sancho, shit! \\
\hline $\begin{array}{l}\text { Carne trémula } \\
\text { (1997) }\end{array}$ & -¡Joder! (Víctor) & Shit! \\
\hline
\end{tabular}

These two words found in the translations are not as offensive and unrefined as the ST word. Surprisingly the translators have softened the ST, in contrast to previous instances in which the vulgarity of the ST was preserved. At other times the TTs reflect an omission of the swear word, probably because the translators thought their rendering was not crucial to the on-going action. But in so doing they have deprived the target audience of the real register of the character:

\begin{tabular}{|l|l|l|}
\hline $\begin{array}{l}\text { FILM AND } \\
\text { YEAR }\end{array}$ & SOURCE TEXT & TARGET TEXT \\
\hline $\begin{array}{l}\text { La ley del deseo } \\
\text { (1987) }\end{array}$ & $\begin{array}{l}\text {-...y creo que lo he } \\
\text { cumplido a lo largo de } \\
\text { todos estos años ijoder! } \\
\text { (Pablo) }\end{array}$ & $\begin{array}{l}\text {..and I've kept my } \\
\text { bargain } \\
\text { over the years. }\end{array}$ \\
\hline $\begin{array}{l}\text { La ley del deseo } \\
\text { (1987) }\end{array}$ & $\begin{array}{l}\text {-iJoder, con todo lo que } \\
\text { te has metido esta }\end{array}$ & After all you've taken \\
\hline
\end{tabular}




\begin{tabular}{|c|c|c|}
\hline & noche...! (Pablo) & tonight...!? \\
\hline ;Átame! (1990) & $\begin{array}{l}\text {-¡Joder, qué carrerón! } \\
\text { (Marina) }\end{array}$ & What a career! \\
\hline ¡Átame! (1990) & -¡Joder! (Driver) & ::::::::::: \\
\hline Kika (1993) & $\begin{array}{l}\text {-¡Que por qué no dejas } \\
\text { de beber, joder! (Ramón) }\end{array}$ & $\begin{array}{l}\text { Why don't you stop } \\
\text { drinking! }\end{array}$ \\
\hline $\begin{array}{l}\text { Carne trémula } \\
\text { (1997) }\end{array}$ & $\begin{array}{l}\text {-¡Joder, cómo se rompe } \\
\text { la cintura! (Víctor) }\end{array}$ & $\begin{array}{l}\text { Did you see that } \\
\text { dribble? }\end{array}$ \\
\hline $\begin{array}{l}\text { Carne trémula } \\
\text { (1997) }\end{array}$ & -¡Joder! (David) & 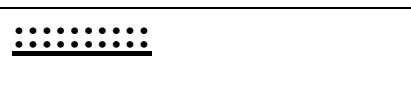 \\
\hline $\begin{array}{l}\text { ¿Qué he hecho yo } \\
\text { para merecer esto? } \\
(1984)\end{array}$ & $\begin{array}{l}\text {-¡Joder, cómo se lo } \\
\text { monta el niño! (Tony) }\end{array}$ & $\begin{array}{l}\text { That kid's got it } \\
\text { made! }\end{array}$ \\
\hline
\end{tabular}

"Cojones", literally "balls", is also a very common swear word in Spanish. There is an equivalent in English, but it is not used so frequently as an expletive as this Spanish word, and its literal translation would make no sense to the target spectator. Instead, the translators have used terms that have already appeared in the analysis:

\begin{tabular}{|l|l|l|}
\hline $\begin{array}{l}\text { FILM AND } \\
\text { YEAR }\end{array}$ & SOURCE TEXT & TARGET TEXT \\
\hline iÁtame! (1990) & - -iCojones! (Doña Paquita) & Damn! \\
\hline $\begin{array}{l}\text { Carne trémula } \\
\text { (1997) }\end{array}$ & $-i C o j o n e s !($ David) & Fuck! \\
\hline
\end{tabular}


While the second example displays a swear word with the same intensity as the original, the TT of the first example is not as offensive as the ST.

As regards "coño", it must be said once again that its literal translation would make no sense to the target audience, as it is not used as an expletive. Nevertheless, the translators of these films have displayed many different options:

\begin{tabular}{|c|c|c|}
\hline FILM AND YEAR & SOURCE TEXT & TARGET TEXT \\
\hline $\begin{array}{l}\text { ¿Qué he hecho yo } \\
\text { para merecer esto? } \\
\text { (1984) }\end{array}$ & $\begin{array}{l}\text {-iQué raro, coño...! } \\
\text { (Psychologist) }\end{array}$ & Weird... \\
\hline $\begin{array}{l}\text { ¿Qué he hecho yo } \\
\text { para merecer esto? } \\
\text { (1984) }\end{array}$ & $\begin{array}{l}\text {-¡Con quién cenaría yo } \\
\text { aquí anoche, coño! } \\
\text { (Psychologist) }\end{array}$ & $\begin{array}{l}\text { Whom did I have } \\
\text { supper with? }\end{array}$ \\
\hline $\begin{array}{l}\text { Carne trémula } \\
\text { (1997) }\end{array}$ & -¡Deja, coño! (Sancho) & Lay off! \\
\hline $\begin{array}{l}\text { Carne trémula } \\
\text { (1997) }\end{array}$ & $\begin{array}{l}\text {-¡Para, coño, para! } \\
\text { (D.Centro) }\end{array}$ & Stop, dammit! \\
\hline $\begin{array}{l}\text { Tacones lejanos } \\
\text { (1991) }\end{array}$ & $\begin{array}{l}\text {-¡Estate quieta, coño! } \\
\text { (Chon) }\end{array}$ & Stop it, my ass! \\
\hline $\begin{array}{l}\text { Todo sobre mi } \\
\text { madre (1999) }\end{array}$ & $\begin{array}{l}\text {-¡Coño, que es imposible } \\
\text { aprendérselo sólo } \\
\text { oyéndolo por los } \\
\text { altavoces! (Nina) }\end{array}$ & $\begin{array}{l}\text { It's fucking impossible } \\
\text { to learn } \\
\text { it over the } \\
\text { loudspeakers!// }\end{array}$ \\
\hline
\end{tabular}


These examples show different translations. In the first three there is a complete omission of the term. The other three instances display swear words that clearly convey the same intensity of the original.

The word "hostia" ("Host") was previously dealt with in the section on sexual and scatological expressions. It is also used as a common swear word, and exemplifies the common use of religious terms in Spanish:

Only a people with an intimate sense of religion, like Spaniards, could blaspheme so much and so well. (Allinson 2001: 44)

These examples show one of the "strongest and one of the most common expletives" (ibid):

\begin{tabular}{|l|l|l|}
\hline FILM AND YEAR & SOURCE TEXT & TARGET TEXT \\
\hline $\begin{array}{l}\text { La ley del deseo } \\
\text { (1987) }\end{array}$ & $\begin{array}{l}- \text {-iQue estoy muy loco, } \\
\text { hostias! (Antonio) }\end{array}$ & I'm crazy, damn it! \\
\hline $\begin{array}{l}\text { La ley del deseo } \\
\text { (1987) }\end{array}$ & - -Hostia! (Antonio) & Christ! \\
\hline $\begin{array}{l}\text { Mujeres al borde } \\
\text { de un ataque de } \\
\text { nervios (1988) }\end{array}$ & $-¡$ Hostias! (Carlos) & Christ! \\
\hline $\begin{array}{l}\text { Carne trémula } \\
\text { (1997) }\end{array}$ & $\begin{array}{l}-¡ \text { iHostias, la sartén! } \\
\text { (Víctor) }\end{array}$ & Christ, the frying pan! \\
\hline $\begin{array}{l}\text { Carne trémula } \\
\text { (1997) }\end{array}$ & $-¡ H o s t i a s !$ (Víctor) & Christ! \\
\hline
\end{tabular}


"Christ" seems to be the closest translation for "hostia(s)", as it preserves both the religious connotations and the intensity of the original.

Spaniards are said to swear more than English speakers in the UK and the USA. The literal translation of the meaning of some swear words used in Spanish as expletives (cojones, coño) would make no sense to an English-speaking person (balls, cunt), as they do not exist as swear words in the target culture. In Almodóvar's films, for the most part translators keep the vulgarity of the original swear words by means of their equivalents in English. But there are certain Spanish words that do not have such an equivalent, and whose translations are as unrefined as the source ones. Due to the limited variety of taboo expletives in English, translators have to use the same unrefined target word for different Spanish expletives. Occasionally the source expletive has simply not been translated, perhaps in the interests of avoiding repetition, but this implies a loss in the characters' register. Another such loss is produced by the softening of some of this bad language. Indeed, as a result of these two translation strategies, Almodóvar's characters do not appear as offensive and rude in translation as they really are in the original Spanish.

\subsubsection{Slang and Colloquial Expressions}

[...] People's background will have an influence on how they speak, but also the situation in which they find themselves. Film makes good use of this, carefully manipulating linguistic styles and registers to narrative ends. (Díaz Cintas \& Remael 2007: 187) 
Because the language of the characters in these films is full of slang and colloquial expressions, the audiovisual translator has a hard task. It is not always possible to find an equivalent for these words and expressions in English, so the translator has to come up with strategies to preserve the register of the original.

Laberinto de pasiones (1982) is a good example of a film in which slang and colloquial expressions are to be found everywhere. The ambiance of the film is the 80 s "movida":

"La Movida", the all-purpose phrase coined in Madrid to signify life after Franco, sexual freedom, punk rockers, sunshine, great food, good times, and the general explosion of creative expression that a nation experiences when moving from a dark past of repression into the light of freedom. (Russo 1988: 13)

It is a combination of new age, new music, new fashion, a new life for the Spanish society that had been repressed for a long time. This film deals with people whose lives are interconnected. All the characters belonging to the world of music, such as Sexi and her band, are characterized by their tone. Sexi, a rich, young nymphomaniac, is the leader of a band. Almost every comment she makes is couched in highly colloquial Spanish, whose translation into English can often only convey the information of the ST, leaving aside all those socio-linguistic markers that are part of her identity:

\begin{tabular}{|l|l|l|}
\hline FILM AND YEAR & SOURCE TEXT & TARGET TEXT \\
\hline $\begin{array}{l}\text { Laberinto de } \\
\text { pasiones }(1982)\end{array}$ & $\begin{array}{l}\text {-Es que hoy no tengo el } \\
\text { cuerpo para esto, de }\end{array}$ & I'm not in the mood. \\
\hline
\end{tabular}




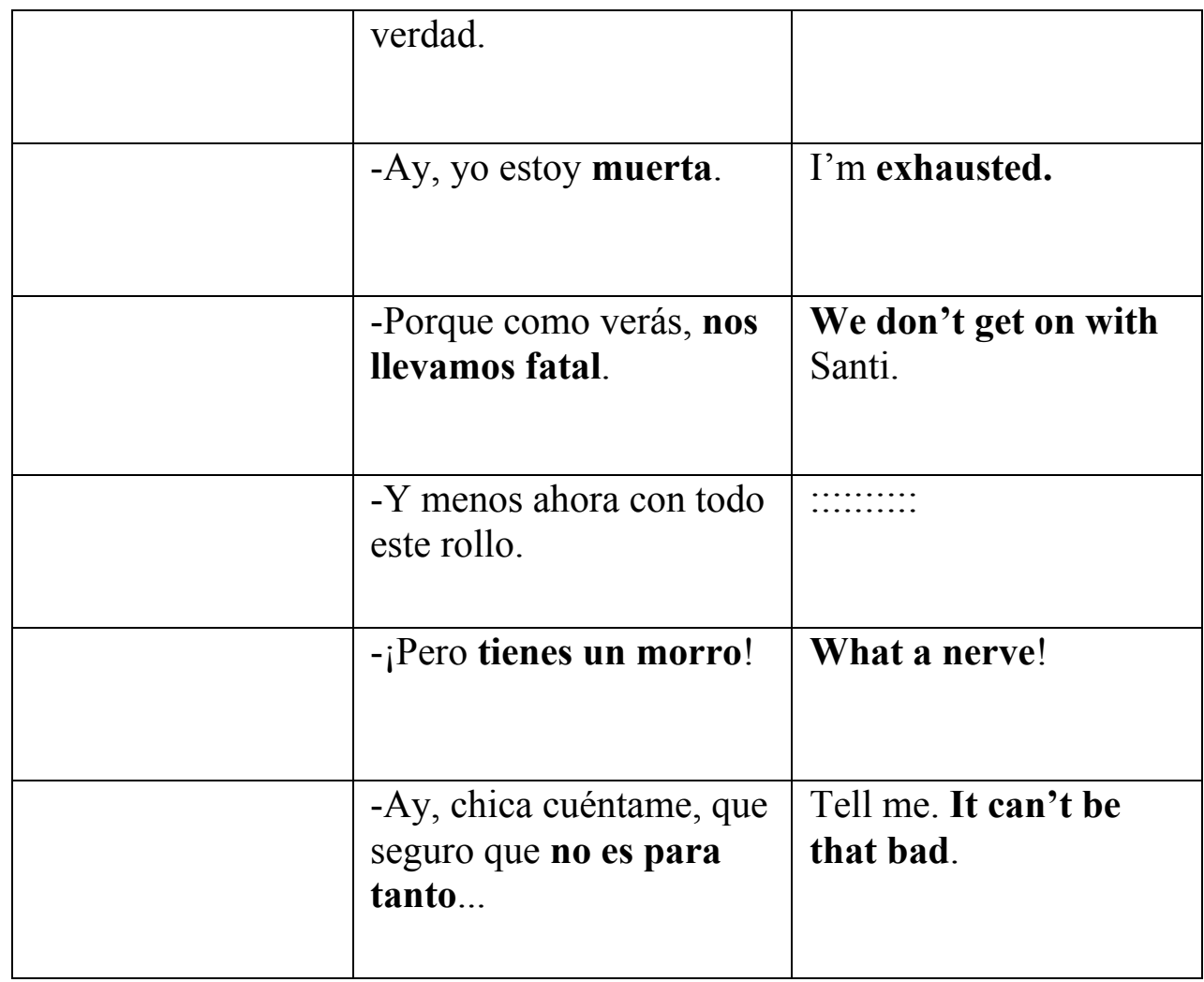

When somebody asks Sexi how she is, she always replies "divina", a word that started to be widely used in the 80 s to express one's excellent condition. Toraya asks her how she is:

\begin{tabular}{|l|l|l|}
\hline FILM AND YEAR & SOURCE TEXT & TARGET TEXT \\
\hline $\begin{array}{l}\text { Laberinto de } \\
\text { pasiones (1982) }\end{array}$ & -¡Divina! & Wonderful! \\
\hline
\end{tabular}

So instead of using the word "divine", the subtitles contain the word "wonderful" that does not transmit the exaggerated 80s expression of the original. When her band mates ask her the same question, Sexi replies: 


\begin{tabular}{|l|l|l|}
\hline FILM AND YEAR & SOURCE TEXT & TARGET TEXT \\
\hline $\begin{array}{l}\text { Laberinto de } \\
\text { pasiones (1982) }\end{array}$ & $\begin{array}{l}\text {-Pues mira, divina, } \\
\text { cansada pero encantada. }\end{array}$ & Tired, but happy. \\
\hline
\end{tabular}

Here the translator has even omitted the adjective, bringing about a real loss in register. When her new friend Queti, who is her fan and firmly admires her, is so happy with their just-born friendship that she uses Sexi's clothes and even adopts her tone, the subtitles again fail to reflect it:

\begin{tabular}{|l|l|l|}
\hline FILM AND YEAR & SOURCE TEXT & TARGET TEXT \\
\hline $\begin{array}{l}\text { Laberinto de } \\
\text { pasiones (1982) }\end{array}$ & -Divino... & It's beautiful. \\
\hline
\end{tabular}

When Sexi invites Queti to see her place, Queti is astonished at the colors and ornaments in Sexi's room:

\begin{tabular}{|l|l|l|}
\hline FILM AND YEAR & SOURCE TEXT & TARGET TEXT \\
\hline $\begin{array}{l}\text { Laberinto de } \\
\text { pasiones (1982) }\end{array}$ & $\begin{array}{l}\text {-Pero bueno ¡qué } \\
\text { monada de paredes! } \\
\text { ¡Uy que colores más } \\
\text { divinos! }\end{array}$ & $\begin{array}{l}\text { Oh! What pretty } \\
\text { walls. And } \\
\text { such gorgeous colors. }\end{array}$ \\
\hline
\end{tabular}

In this example, the adjective "gorgeous", however, does convey the tone of the original. Queti is equally impressed when she meets Sexi's dad: 


\begin{tabular}{|c|c|c|}
\hline FILM AND YEAR & SOURCE TEXT & TARGET TEXT \\
\hline $\begin{array}{l}\text { Laberinto de } \\
\text { pasiones (1982) }\end{array}$ & $\begin{array}{l}\text {-¡Uy cómo es de guapo! } \\
\text { Me ha 'encantao'. }\end{array}$ & He's so goodlooking! \\
\hline & $\begin{array}{l}\text {-Jo, qué increíble. } \\
\text { ¿Tiene mucho éxito? ¿Y } \\
\text { tu madre no se } \\
\text { mosquea? }\end{array}$ & $\begin{array}{l}\text { Really? And your } \\
\text { mother } \\
\text { doesn't mind? }\end{array}$ \\
\hline
\end{tabular}

But here the colloquial force of these texts has disappeared in the translations, which merely reflect the message of the ST.

Queti's social condition is not like Sexi's. The former belongs to a working class family, while Sexi's father is a well-known doctor. This comes through in the way she talks. When Queti tries to adopt Sexi's register, her way of speaking gives her away, and despite their usual vulgarity, Sexi's comments seem more refined than Queti's. Surprisingly, this distinction can be detected in the translation by the insertion of colloquialisms in the first of the following examples, while the second shows a neutralization of the colloquial register is present in the second one:

\begin{tabular}{|l|l|l|}
\hline FILM AND YEAR & SOURCE TEXT & TARGET TEXT \\
\hline $\begin{array}{l}\text { Laberinto de } \\
\text { pasiones (1982) }\end{array}$ & $\begin{array}{l}\text {-Seguro que le tienes } \\
\text { salido todo el día. Lo que } \\
\text { pasa que te has vuelto } \\
\text { tan, tan discreta que... } \\
\text { (Queti) }\end{array}$ & $\begin{array}{l}\text { You got him hot for } \\
\text { it./ } \\
\text { But since you've } \\
\text { gotten so cool... }\end{array}$ \\
\hline & $\begin{array}{l}\text {-¿Que tú le dijiste eso? } \\
\text { ¡Uy por Dios, qué cosa } \\
\text { más antigua! Tú chica }\end{array}$ & $\begin{array}{l}\text { That's an old trick! } \\
\text { You really have } \\
\text { changed. }\end{array}$ \\
\hline
\end{tabular}




\begin{tabular}{|l|l|l|}
\hline & $\begin{array}{l}\text { no pareces la } \\
\text { misma...(Queti) }\end{array}$ & \\
\hline
\end{tabular}

There are several other characters who also belong to Sexi's world, and whose comments are rich in slang words and expressions. Early on in the film Fabio says:

\begin{tabular}{|l|l|l|}
\hline FILM AND YEAR & SOURCE TEXT & TARGET TEXT \\
\hline $\begin{array}{l}\text { Laberinto de } \\
\text { pasiones (1982) }\end{array}$ & $\begin{array}{l}\text {-Sin dinero nena, no } \\
\text { coche, no chica, no tate, } \\
\text { no bici, no rimmel. }\end{array}$ & $\begin{array}{l}\text { No money, sweetie, so } \\
\text { no car, no girl, no } \\
\text { dope, no vices. }\end{array}$ \\
\hline & $\begin{array}{l}-i \text { Sírveme alcohol por un } \\
\text { tubo! }\end{array}$ & $\begin{array}{l}\text { Alcohol by the } \\
\text { bucketful! }\end{array}$ \\
\hline
\end{tabular}

The first of these examples exhibits equivalents for the source slang words, even though the subtitles do not display the translation of words such as "bici" ("bike") and "rimmel" ("mascara"). Probably they are not significant for an understanding of the message, and their insertion in the subtitles would constitute a constraint for the target spectator. Here the translator has decided to translate only the slang part of this comment, so as not to provide the spectator with secondary information whose presence in the subtitles would be irrelevant in its reading. In the second example, an equivalent effect has been attained, and the target audience is not deprived of the character's register.

Different characters share the same tone: 


\begin{tabular}{|c|c|c|}
\hline $\begin{array}{l}\text { Laberinto de } \\
\text { pasiones (1982) }\end{array}$ & $\begin{array}{l}\text {-Busque en las saunas, en } \\
\text { los bares de locas. } \\
\text { Bueno, ya } \\
\text { sabe...(Mohamed) }\end{array}$ & $\begin{array}{l}\text { Try the saunas, kinky } \\
\text { bars, } \\
\text { You know the kind of } \\
\text { place... }\end{array}$ \\
\hline & $\begin{array}{l}\text {-Déjate de chorradas, } \\
\text { hombre (Manager) }\end{array}$ & ::::::::::::: \\
\hline & $\begin{array}{l}\text {-¡Déjate de bobadas! } \\
\text { (Guy 1) }\end{array}$ & Cut it out! \\
\hline & $\begin{array}{l}\text {-...Y total qué...ni un } \\
\text { duro...(Girlfriend) }\end{array}$ & and never got a penny \\
\hline & $\begin{array}{l}\text {-¿Te estás quedando } \\
\text { conmigo? (Eusebio) }\end{array}$ & $\begin{array}{l}\text { Are you putting me } \\
\text { on? }\end{array}$ \\
\hline
\end{tabular}

In the first example the subtitles obtain the equivalent effect by means of a fluid style and the word "kinky" as the equivalent for "de locas".

Whereas the second example displays an omission of the source expression, the third one exhibits "cut it out", which is the equivalent for both expressions (the second and the third). The last two examples also exhibit equivalent translations, thereby preserving the register of the characters.

\begin{tabular}{|l|l|l|}
\hline FILM AND YEAR & SOURCE TEXT & TARGET TEXT \\
\hline $\begin{array}{l}\text { Laberinto de } \\
\text { pasiones (1982) }\end{array}$ & $\begin{array}{l}\text {-Bueno tío, ya está bien. } \\
\text { Yo soporto a los } \\
\text { 'colgaos', pero ya está } \\
\text { bien de montar } \\
\text { números. iAnda, } \\
\text { piérdete por ahí! } \\
\text { (Eusebio) }\end{array}$ & $\begin{array}{l}\text { OK. I've had enough } \\
\text { of this shit.// }\end{array}$ \\
\hline
\end{tabular}




\begin{tabular}{|l|l|l|}
\hline & $\begin{array}{l}\text {-Ay, mira chica, tú eres } \\
\text { una borde (Angustias) }\end{array}$ & $\begin{array}{l}\text { You've got a big } \\
\text { mouth. }\end{array}$ \\
\hline & $\begin{array}{l}\text {-Y tienes más morro } \\
\text { que una zorra. Como no } \\
\text { te calles te voy a romper } \\
\text { la lamparería (Angustias) }\end{array}$ & $\begin{array}{l}\text { If you don't shut it, I'll } \\
\text { bust up your shop...// } \\
\text { and your mouth. }\end{array}$ \\
\hline
\end{tabular}

In the first example the subtitles show a synopsis of the ST. While the ST contains slang words and relatively inoffensive expressions, the TT displays coarse and vulgar language, which is remarkable given the tendency of translators to ignore slang and to soften vulgar terms. The second example displays a translation that has nothing to do with the ST: while the ST says "Hey girl, you are a nasty piece of work" (my own translation), the TT exhibits a different insult. In the third example there is no trace of the slang expression used in the ST.

In ¿Qué he hecho yo para merecer esto? (1984) Toni, one of the protagonist's sons, uses "Cheli", which is rich in neologisms and Anglicisms. While these words are easily understood by natives, as well as by foreign speakers proficient in Spanish, they are so closely bound to local cultural phenomena that they are very difficult to deal with in the process of translation. Toni is a young drug-dealer with a special relationship to his grandmother who lives with the family. He addresses his parents as "viejo/a" ("old man/woman"), uses the word "guay" to refer to something that he likes, and is constantly complaining about school and homework.

\begin{tabular}{|l|l|l|}
\hline FILM AND YEAR & SOURCE TEXT & TARGET TEXT \\
\hline
\end{tabular}




\begin{tabular}{|l|l|l|}
\hline $\begin{array}{l}\text { ¿Qué he hecho yo } \\
\text { para merecer esto? } \\
(1984)\end{array}$ & -Cantidad de chungos. & Just wack.... \\
\hline & -Sí, cantidad de fácil... & It sure is... \\
\hline & -Chungo, como siempre. & Wack, as usual. \\
\hline
\end{tabular}

Toni complains that his homework is "chungo", a Cheli word widely understood by Spanish speakers as meaning "difficult". The translation displays the word "wack" in an attempt to preserve the register of the original, and thus successfully transmits Toni's way of speaking. In the third example, the translation also exhibits the equivalent effect, yet the second example does not keep the same register as the slang shown in the ST is neutralized. When Toni talks about money, he does not use “pesetas", but "duros" (an old five-peseta coin) and "talego"(an old one thousand-peseta note):

\begin{tabular}{|l|l|l|}
\hline FILM AND YEAR & SOURCE TEXT & TARGET TEXT \\
\hline $\begin{array}{l}\text { ¿Qué he hecho yo } \\
\text { para merecer esto? } \\
(1984)\end{array}$ & $\begin{array}{l}\text {-¿Sólo cien duros? } \\
\text { Pásame un talego, por lo } \\
\text { menos. }\end{array}$ & $\begin{array}{l}\text { No more? A ten } \\
\text { at least... }\end{array}$ \\
\hline & $\begin{array}{l}\text {-Y te cobro un talego } \\
\text { porque eres vecina mía, } \\
\text { que si no, te cobraría } \\
\text { mínimo el } 25 \% .\end{array}$ & $\begin{array}{l}\text { And I'm giving you a } \\
\text { special price...// } \\
\text {...usually, it's 25\%. }\end{array}$ \\
\hline
\end{tabular}

Because of the difficulty of translating slang terms for different currencies, the translator may have decided to leave out these words and their possible equivalents, thus omitting any mention of the source 
currency. Only the first example contains a quantity of money, "a ten", but without specifying "of what", and the second one omits any mention of currency. In both these examples there is a loss of register. After selling cocaine to his neighbor Cristal, Toni washes his hands of it in case of trouble:

\begin{tabular}{|l|l|l|}
\hline FILM AND YEAR & SOURCE TEXT & TARGET TEXT \\
\hline $\begin{array}{l}\text { ¿Qué he hecho yo } \\
\text { para merecer esto? } \\
\text { (1984) }\end{array}$ & $\begin{array}{l}\text {-Si hay alguna movida } \\
\text { yo no quiero saber nada. } \\
\text { Que soy un chinorri. }\end{array}$ & $\begin{array}{l}\text { I don't wanna know } \\
\text { nothing. I'm a kid. }\end{array}$ \\
\hline
\end{tabular}

There is an omission for the expression "si hay alguna movida", the equivalent of which would be "if there is trouble", even though it would not reflect the original slang. "Chinorri" is translated as "kid", which again does not reflect the ST register. In addition, the TT exhibits a double negation, an ungrammatical form, perhaps intended to reflect Toni's register. Yet, Toni is simply using slang, and thus not breaking any grammatical rules. Later on he makes a deal with Cristal:

\begin{tabular}{|l|l|l|}
\hline FILM AND YEAR & SOURCE TEXT & TARGET TEXT \\
\hline $\begin{array}{l}\text { ¿Qué he hecho yo } \\
\text { para merecer esto? } \\
\text { (1984) }\end{array}$ & $\begin{array}{l}\text {-Mira, si te tiras a mi } \\
\text { hermano, te paso una } \\
\text { papelina de un talego. }\end{array}$ & $\begin{array}{l}\text { If you screw my } \\
\text { brother,/ } \\
\text { I'll give you a line... }\end{array}$ \\
\hline
\end{tabular}

Once again the translator has omitted any equivalent for "talego" and opted for "a line" as a substitute for "una papelina de un talego", or a one thousand-peseta cocaine bag. Probably an exact translation would not be 
relevant to the action, and there is no harm in depriving the spectator of this information. The subtitles in this instance satisfactorily transmit both the message and the register with "to screw" and "a line".

\begin{tabular}{|l|l|l|}
\hline FILM AND YEAR & SOURCE TEXT & TARGET TEXT \\
\hline $\begin{array}{l}\text { ¿Qué he hecho yo } \\
\text { para merecer esto? } \\
(1984)\end{array}$ & -Yo quiero el talego. & $\begin{array}{l}\text {...Gimme } \\
\text { the dough! }\end{array}$ \\
\hline & $\begin{array}{l}\text {-Que va, que va, que va. } \\
\text { Yo quiero el talego. }\end{array}$ & The money. \\
\hline
\end{tabular}

These examples show two different translations for the same word "talego". Whereas the first one exhibits the slang word "dough" which is an equivalent for the source one, the second one displays the neutral word "money", so that the register is not kept in the subtitle. Taken together, these examples show an inconsistency in the translation of "talego", a difficulty in translation that might have been overcome by using the word "dough" in its colloquial usage.

One day Toni wakes up with a strange itch and refuses to attend school:

\begin{tabular}{|l|l|l|}
\hline FILM AND YEAR & SOURCE TEXT & TARGET TEXT \\
\hline $\begin{array}{l}\text { ¿Qué he hecho yo } \\
\text { para merecer esto? } \\
\text { (1984) }\end{array}$ & $\begin{array}{l}\text {-Oye vieja, que paso de } \\
\text { ir al colegio. }\end{array}$ & I ain't going to school. \\
& & \\
\hline
\end{tabular}


We see an omission of the vocative "vieja", a derogatory word used to address old people, and which has slang connotations. The translator has opted for an ungrammatical form, "ain't" instead of "am not", in order to reflect the character's particular tone. When he says good-bye to his mother as he is leaving with his grandmother to go to the village, she wants to know if he will attend school, to which he replies:

\begin{tabular}{|l|l|l|}
\hline FILM AND YEAR & SOURCE TEXT & TARGET TEXT \\
\hline $\begin{array}{l}\text { ¿Qué he hecho yo } \\
\text { para merecer esto? } \\
(1984)\end{array}$ & $\begin{array}{l}\text {-No. Me buscaré un } \\
\text { curro en el campo. }\end{array}$ & No. I'll work the land. \\
\hline
\end{tabular}

Again, the subtitles do not reflect the slang of the original and only include the neutral expression "to work the land", which in Spanish would be "trabajar la tierra, el campo".

In La ley del deseo (1985) all the characters in the film have their own way of talking. The film introduces two members of a family: Pablo, who is a homosexual porno film-maker, and his transsexual sister, Tina. Pablo's success in the film industry has enabled him to reach a good economic and social position. His sister Tina, however, who is in charge of a little girl called Ada, receives a monthly payment from her brother as she does not have any income. Dialogues such as the following are good examples of their use of slang and colloquialisms: 


\begin{tabular}{|l|l|l|}
\hline $\begin{array}{l}\text { La ley del deseo } \\
(1985)\end{array}$ & $\begin{array}{l}\text {-Bueno, si os } \\
\text { amuermáis, dadme un } \\
\text { toque (Pablo) }\end{array}$ & $\begin{array}{l}\text { If you get bored } \\
\text { give me a call. }\end{array}$ \\
\hline & $\begin{array}{l}\text {-Ni un tío ni una tía... } \\
\text { (Tina) }\end{array}$ & Neither guys nor girls, \\
\hline & $\begin{array}{l}\text {-No, es que se ha } \\
\text { enrollado con el altar.... } \\
\text { (Tina) }\end{array}$ & She's into an altar thing, \\
\hline & $\begin{array}{l}\text {-Me trae negra con el } \\
\text { voto de silencio. Todo el } \\
\text { día con la pizarra (Tina) }\end{array}$ & All day with \\
her blackboard! \\
\hline
\end{tabular}

While the colloquial expression "me trae negra" ("she makes me upset") is omitted in the last example, the other three do exhibit a colloquial English expression that attempts to respect the register of the original. Even the TV hostess exhibits colloquialisms that are reflected in the translation:

\begin{tabular}{|l|l|l|}
\hline FILM AND YEAR & SOURCE TEXT & TARGET TEXT \\
\hline $\begin{array}{l}\text { La ley del deseo } \\
(1985)\end{array}$ & $\begin{array}{l}\text {-¿Qué es lo que más te } \\
\text { chifla y lo que más te } \\
\text { amuerma del amor? (TV } \\
\text { hostess) }\end{array}$ & $\begin{array}{l}\text { What's an upper } \\
\text { for you...?// } \\
\text {...and a downer } \\
\text { for you in love? }\end{array}$ \\
\hline
\end{tabular}

At some point Ada's mother comes to visit them and wants to take her daughter back with her. Her language also exhibits colloquial expressions:

\begin{tabular}{|l|l|l|}
\hline FILM AND YEAR & SOURCE TEXT & TARGET TEXT \\
\hline
\end{tabular}




\begin{tabular}{|l|l|l|}
\hline $\begin{array}{l}\text { La ley del deseo } \\
(1985)\end{array}$ & $\begin{array}{l}\text {-Sí. ¿Y tú de qué vas? } \\
\text { (Bibiana) }\end{array}$ & $\begin{array}{l}\text { You too. What are you } \\
\text { dressed up as? }\end{array}$ \\
\hline & $\begin{array}{l}\text {-Estáis como dos cabras } \\
\text { (Bibiana) }\end{array}$ & You two are crazy. \\
\hline & $\begin{array}{l}\text {-No seas resabida } \\
\text { (Bibiana) }\end{array}$ & Don't be pretentious. \\
\hline & $\begin{array}{l}\text {-Esta niña me pone } \\
\text { histérica (Bibiana) }\end{array}$ & $\begin{array}{l}\text { I can't stand } \\
\text { that girl! }\end{array}$ \\
\hline
\end{tabular}

All of these translations display the original content of the ST, but the original colloquial tone is not kept since the expressions used are neutral.

Tina's language, as mentioned above, is full of slang and colloquialisms, and almost all her comments contain a word or expression of this type:

\begin{tabular}{|c|c|c|}
\hline FILM AND YEAR & SOURCE TEXT & TARGET TEXT \\
\hline \multirow[t]{4}{*}{$\begin{array}{l}\text { La ley del deseo } \\
\text { (1985) }\end{array}$} & $\begin{array}{l}\text { - } \text { Vaya pejiguera que le } \\
\text { ha salido a la Virgen } \\
\text { contigo, niña! }\end{array}$ & $\begin{array}{l}\text { The Virgin's got a } \\
\text { nuisance / } \\
\text { on her hands with } \\
\text { you! }\end{array}$ \\
\hline & -¡Vamos pedigüeña! & Let's go, you pest! \\
\hline & $\begin{array}{l}-¿ \text { ¿No se asa con esa } \\
\text { chaqueta? }\end{array}$ & $\begin{array}{l}\text { Aren't you hot with } \\
\text { that jacket on? }\end{array}$ \\
\hline & $\begin{array}{l}\text {-Lo que me deprime es ir } \\
\text { siempre de } \\
\text { zarrapastrosa. }\end{array}$ & $\begin{array}{l}\text { What I don't like is } \\
\text { always / } \\
\text { being slovenly. }\end{array}$ \\
\hline
\end{tabular}


Except for the second example in which the translation does not correspond with the original ("pest" in Spanish it means "pelma, fastidio", and "pedigüeña" is "mooching"), the other examples for the most part convey the register of the original.

The character of Antonio, despite his high class origins, also speaks in this way:

\begin{tabular}{|c|c|c|}
\hline FILM AND YEAR & SOURCE TEXT & TARGET TEXT \\
\hline \multirow[t]{5}{*}{$\begin{array}{l}\text { La ley del deseo } \\
(1985)\end{array}$} & $\begin{array}{l}\text {-¿Qué pasa? ¿Que me } \\
\text { estás dando marcha? }\end{array}$ & $\begin{array}{l}\text { What's wrong? Are } \\
\text { you } \\
\text { trying to fade me out? }\end{array}$ \\
\hline & $\begin{array}{l}\text {-Sargento, vamos a entrar } \\
\text { adentro que estoy en } \\
\text { pelotas. }\end{array}$ & Let's go inside. \\
\hline & -...se mosqueó. & ...he got uptight. \\
\hline & $\begin{array}{l}\text {-Yo tuve un rollo con } \\
\text { ella. }\end{array}$ & $\begin{array}{l}\text { I was getting it on } \\
\text { with her. }\end{array}$ \\
\hline & $\begin{array}{l}\text { - ¡Si alguien se mueve, le } \\
\text { vuelo la cabeza! }\end{array}$ & $\begin{array}{l}\text { If someone moves, } \\
\text { I'll shoot! }\end{array}$ \\
\hline
\end{tabular}

In general, these translations convey the meaning and register of the original, with the following exceptions. In the second example, the character informs the police that he is naked, information that is omitted in the TT. In the third example, the translation is not the right one since "mosquearse" means "to get pissed off/upset", not to "get uptight", which in Spanish would be "ponerse nervioso". In the last example, where "volar la cabeza" means to "blow one's head off", while the 
subtitle uses the general term "shoot" without specifying what is going to be shot.

Antonio's mother, with her strong Andalusian accent, also has a particular way of speaking. (I have tried to reproduce the accent orthographically):

\begin{tabular}{|l|l|l|}
\hline FILM AND YEAR & SOURCE TEXT & TARGET TEXT \\
\hline $\begin{array}{l}\text { La ley del deseo } \\
(1985)\end{array}$ & -¡A que va a sé un porro! & It isn't a joint, is it? \\
\hline & -¡Me vai a quitá la vida! & It'll be death of me! \\
\hline & $\begin{array}{l}\text {-¡Hiho de mi arma! ¡Qué } \\
\text { te han esho! }\end{array}$ & $\begin{array}{l}\text { What did they do to } \\
\text { you, } \\
\text { son? }\end{array}$ \\
\hline & $\begin{array}{l}\text { ¡Cómo que ná! } \\
\text { mu raro úrtimamente. }\end{array}$ & $\begin{array}{l}\text { What do you mean? } \\
\text { strange } \\
\text { lately. }\end{array}$ \\
\hline & $\begin{array}{l}\text {-Ya desía que ehtaba tú } \\
\text { vé con ese corrompío. }\end{array}$ & $\begin{array}{l}\text { My son isn't involved } \\
\text { in perverted business. }\end{array}$ \\
\hline & \begin{tabular}{l}
-No se ha movío de casa. \\
\hline
\end{tabular} & \begin{tabular}{l} 
He stayed home. \\
\hline
\end{tabular} \\
\hline
\end{tabular}

The question of accent will be commented on in the next section (3.2.6). The colloquial quality of these expressions is not kept in the subtitles; instead, the translator has opted for a translation that reflects the original content, leaving aside the peculiarities of accent and colloquial speech. 
Matador (1986) is a film about crime and bullfighting. At the beginning, the audience sees a bullfighting school in which the students are learning this art with the help of their "maestro" Diego. One of his female students refers to him as "matao", and the subtitle reflects the English equivalent of the literal meaning of 'matao':

\begin{tabular}{|l|l|l|}
\hline FILM AND YEAR & SOURCE TEXT & TARGET TEXT \\
\hline Matador (1986) & -Está más ‘matao'. & The man's beaten up. \\
& & \\
\hline
\end{tabular}

Diego shows his sexist personality when he refers to his female students as:

\begin{tabular}{|l|l|l|}
\hline FILM AND YEAR & SOURCE TEXT & TARGET TEXT \\
\hline Matador (1986) & $\begin{array}{l}\text {-Éstas hoy tienen ganas } \\
\text { de guerra. }\end{array}$ & $\begin{array}{l}\text { Those chicks want } \\
\text { a good time. }\end{array}$ \\
\hline
\end{tabular}

The translator here has opted for "chicks" (tías), even though the ST only displays the pronoun "éstas" ("these"). The expression "tener ganas de guerra" has sexual connotations implied in the TT by means of "chicks" and "have a good time". The effect is more or less equivalent. Diego constantly shows his sexist attitude every time he refers to women as "tías", and the subtitles show consistency in the translation of "tías" as "chicks":

\begin{tabular}{|l|l|l|}
\hline FILM AND YEAR & SOURCE TEXT & TARGET TEXT \\
\hline Matador (1986) & $\begin{array}{l}\text {-¿Nunca has estado con } \\
\text { una tía? }\end{array}$ & $\begin{array}{l}\text { You've never been } \\
\text { with }\end{array}$ \\
\hline
\end{tabular}




\begin{tabular}{|l|l|l|}
\hline & & a chick? \\
\hline & $\begin{array}{l}\text {-A las tías hay que } \\
\text { tratarlas como a los toros. }\end{array}$ & $\begin{array}{l}\text { Chicks are just like } \\
\text { bulls// }\end{array}$ \\
\hline
\end{tabular}

Indeed, Diego talks about women in a derogatory way that is accurately transmitted in the translation:

\begin{tabular}{|l|l|l|}
\hline FILM AND YEAR & SOURCE TEXT & TARGET TEXT \\
\hline Matador (1986) & $\begin{array}{l}\text {-Las pone cachondas } \\
\text { que haya sido torero. }\end{array}$ & $\begin{array}{l}\text { Knowing I was a } \\
\text { bullfighter } \\
\text { fires them up. }\end{array}$ \\
\hline
\end{tabular}

Eva, Diego's girlfriend, works as a model. In one of her shows she has to wear a red wedding dress by Montesinos - played by Almodóvar himself. Eva's mother is worried about the dress, which she thinks is not appropriate. Montesinos replies:

\begin{tabular}{|l|l|l|}
\hline FILM AND YEAR & SOURCE TEXT & TARGET TEXT \\
\hline Matador (1986) & $\begin{array}{l}\text {-No te preocupes, no te } \\
\text { preocupes. Que así te } \\
\text { queda divino y sales así } \\
\text { a la pasarela } \\
\text { (Montesinos) }\end{array}$ & $\begin{array}{l}\text { Don't worry, go out } \\
\text { like this...// } \\
\ldots \text { you look divine. }\end{array}$ \\
\hline & $\begin{array}{l}\text {-Me voy. Que es que } \\
\text { tengo un mogollón... } \\
\text { (Montesinos) }\end{array}$ & I'm off. \\
\hline
\end{tabular}

Here the slang in the second example has not been kept in the translation. Instead, the shortness of the subtitle implies that the translator did not consider the original slang to be relevant to the action of the film. 
In Mujeres (1988), Pepa, the protagonist, has a conversation with the secretary of the studio where she works. The secretary's language is full of colloquial expressions that a Spanish audience would find amusing:

\begin{tabular}{|l|l|l|}
\hline FILM AND YEAR & SOURCE TEXT & TARGET TEXT \\
\hline $\begin{array}{l}\text { Mujeres al borde } \\
\text { de un ataque de } \\
\text { nervios (1988) }\end{array}$ & $\begin{array}{l}\text {-A quien tienes } \\
\text { atacadísimo es a tu } \\
\text { director. }\end{array}$ & $\begin{array}{l}\text { But your director is } \\
\text { here } \\
\text { and he's having a fit. }\end{array}$ \\
\hline & $\begin{array}{l}\text {-iPero qué morrazo } \\
\text { tienes Pepa! }\end{array}$ & $\begin{array}{l}\text { You've got some } \\
\text { nerve! }\end{array}$ \\
& $\begin{array}{l}\text {-Servidora está aquí } \\
\text { para eso. }\end{array}$ & At your service! \\
\hline
\end{tabular}

Even though these subtitles convey the content of the ST, the original humor of the comments is lost. Exaggerated expressions such as "atacadísimo", "morrazo", and the special use of "servidora", all carry humorous connotations when uttered by Lola, but they cannot be reproduced in the translation.

Pepa is also the protagonist of a TV commercial in which she plays the mother of the famous murderer of Cuatro Caminos. She complains about her son's clothes:

\begin{tabular}{|c|c|c|}
\hline FILM AND YEAR & SOURCE TEXT & TARGET TEXT \\
\hline $\begin{array}{l}\text { Mujeres al borde } \\
\text { de un ataque de } \\
\text { nervios (1988) }\end{array}$ & $\begin{array}{l}\text {-...me trae la ropa que } \\
\text { es una pena. }\end{array}$ & $\begin{array}{l}\text {..his clothes are just } \\
\text { filthy... }\end{array}$ \\
\hline
\end{tabular}




\begin{tabular}{|l|l|l|}
\hline & $-¡$ iMire qué hermosura! & Sparkling clean! \\
\hline
\end{tabular}

Again, the colloquialism of such comments is lost in the subtitles that simply reflect the content of the original, and without trying to reproduce the colloquial quality of the Spanish original. Pepa's interventions all throughout the film present this colloquial tone:

\begin{tabular}{|l|l|l|}
\hline FILM AND YEAR & SOURCE TEXT & TARGET TEXT \\
\hline $\begin{array}{l}\text { Mujeres al borde } \\
\text { de un ataque de } \\
\text { nervios }(1988)\end{array}$ & $\begin{array}{l}\text {-Claro que lo sabía. Pero } \\
\text { tragaba. }\end{array}$ & $\begin{array}{l}\text { Sure, but } \\
\text { I put up with it. }\end{array}$ \\
\hline & $\begin{array}{l}\text {-iPues si tú estás } \\
\text { desesperada, yo también } \\
\text { yor me da por tirarme } \\
\text { por la terraza! }\end{array}$ & $\begin{array}{l}\text { So am I, but I don't } \\
\text { jump off terraces. }\end{array}$ \\
\hline & $-i Y$ que dé la cara! & And show his face! \\
\hline
\end{tabular}

The linguistic characteristics of Pepa's way of speaking are once again not reflected in the translations. Besides, the last of these examples contains the expression "dar la cara", which really means "to face something or somebody": instead, the translator has opted for a literal translation from Spanish that makes no sense in this context in the TL ("And show his face!").

Some of the sentences that contain colloquialisms and slang uttered by Pepa have not been translated:

\begin{tabular}{|l|l|l|}
\hline FILM AND YEAR & SOURCE TEXT & TARGET TEXT \\
\hline $\begin{array}{l}\text { Mujeres al borde } \\
\text { de un ataque de }\end{array}$ & $\begin{array}{l}\text {-Hasta que pase el } \\
\text { follón. }\end{array}$ & $: \ldots: \ldots: \ldots::$ \\
\hline
\end{tabular}




\begin{tabular}{|l|l|l|}
\hline nervios (1988) & & \\
\hline & $\begin{array}{l}\text {-...y a dar una vuelta a } \\
\text { los animales. }\end{array}$ & $\ldots \ldots: \ldots: \ldots:$ \\
\hline
\end{tabular}

The reason for this omission is not clear. In general, the translator of the film has shown proficiency in both Spanish and English, and most of the translations are appropriate. But then why omit the translation of these two sentences? Perhaps the translator did not see them as relevant to the plot.

Candela, Pepa's friend, is in trouble and asks for her hospitability. A hilarious character from Málaga with a strong Andalusian accent, uses expressions which are lively and full of colloquialisms and slang:

\begin{tabular}{|c|c|c|}
\hline FILM AND YEAR & SOURCE TEXT & TARGET TEXT \\
\hline \multirow{4}{*}{$\begin{array}{l}\text { Mujeres al borde } \\
\text { de un ataque de } \\
\text { nervios (1988) }\end{array}$} & $\begin{array}{l}\text {-¿A dónde vá tan } \\
\text { puehta? }\end{array}$ & Why so dressed up? \\
\hline & $\begin{array}{l}\text {-Se lo ehtá pasando } \\
\text { pipa. }\end{array}$ & She's having a ball. \\
\hline & $\begin{array}{l}\text {-¿Qué pico tiene la } \\
\text { Pepa! }\end{array}$ & Pepa's some talker! \\
\hline & $\begin{array}{l}\text {-Con el cuadro que hay } \\
\text { en frente, la polisía, tu } \\
\text { madre, tu novia... }\end{array}$ & $\begin{array}{l}\text { In front of your } \\
\text { mother, } \\
\text { the cops, your fiancée! }\end{array}$ \\
\hline
\end{tabular}

But here we see that the humor implied in the linguistic subtleties of Candela's speech is not transmitted in the TT. Not only her accent, but her expressions are full of humor. Yet the translations do not render the same meaning. 
Towards the end of the film Lucía pours "gazpacho" into Pepa's eyes. So as soon as Pepa gets in a taxi with her neighbor Ana, she asks for help:

\begin{tabular}{|l|l|l|}
\hline FILM AND YEAR & SOURCE TEXT & TARGET TEXT \\
\hline $\begin{array}{l}\text { Mujeres al borde } \\
\text { de un ataque de } \\
\text { nervios (1988) }\end{array}$ & $\begin{array}{l}\text {-Sóplame en los ojos, que } \\
\text { me escuecen una } \\
\text { burrada. }\end{array}$ & Blow on my eyes. \\
\hline
\end{tabular}

"Escocer una burrada" is a colloquial expression meaning "to sting in an exaggerate way". But the translator has decided to translate just the beginning of the sentence, omitting that expression. Pepa explains to Anna what has happened:

\begin{tabular}{|c|c|c|}
\hline FILM AND YEAR & SOURCE TEXT & TARGET TEXT \\
\hline $\begin{array}{l}\text { Mujeres al borde } \\
\text { de un ataque de } \\
\text { nervios (1988) }\end{array}$ & $\begin{array}{l}\text {-Mira cómo voy yo, } \\
\text { bañada de gazpacho, } \\
\text { medio ciega y descalza. } \\
\text { ¿Oué crees que voy así } \\
\text { para llamar la } \\
\text { atención? No. Me lo ha } \\
\text { hecho ella. }\end{array}$ & $\begin{array}{l}\text { Look what she did to } \\
\text { me!// } \\
\text { You think I go around } \\
\text { like this for fun? }\end{array}$ \\
\hline
\end{tabular}

Again, the translator has opted to omit some parts of Pepa's speech, such as the description of her present condition and who did it to her. Nor is her speech pattern - her high fluency in Spanish reflected in the subtitles, which is not a synopsis in which bits have been omitted, probably due to space constraints. By contrast, Ana is mad at her boyfriend and says: 


\begin{tabular}{|c|c|c|}
\hline FILM AND YEAR & SOURCE TEXT & TARGET TEXT \\
\hline $\begin{array}{l}\text { Mujeres al borde } \\
\text { de un ataque de } \\
\text { nervios (1988) }\end{array}$ & $\begin{array}{l}\text {-Mira, pienso hacerme } \\
\text { un business, sacar pasta } \\
\text { y comprarle la moto a él. } \\
\text { Y después ipuerta! } \\
\text { ¿Para qué necesito yo a } \\
\text { un tío teniendo una } \\
\text { moto? }\end{array}$ & $\begin{array}{l}\text { I'm gonna get myself } \\
\text { some quick cash...// } \\
\text {...buy myself his bike } \\
\text { and split. With a } \\
\text { bike...// } \\
\text {...who needs a man? }\end{array}$ \\
\hline
\end{tabular}

In some sense Ana's appearance justifies her language. Her leather clothes, her fluffy hair and all her fake jewels give the spectator a clue as to which group of society she belongs to - heavy metal and hard rock were very common in the late 80s. Expressions such as "hacerse un business" - an Anglicism -, "sacar pasta" and "puerta" belong to "Cheli". Although the subtitles here try to convey the register of the original by means of colloquial expressions, it is impossible to avoid the loss of such cultural phenomena.

Ana, who is mad at Lucía for forcing her boyfriend to take her to the airport, says:

\begin{tabular}{|l|l|l|}
\hline FILM AND YEAR & SOURCE TEXT & TARGET TEXT \\
\hline $\begin{array}{l}\text { Mujeres al borde } \\
\text { de un ataque de } \\
\text { nervios (1988) }\end{array}$ & $\begin{array}{l}\text {-¡Pero mira cómo se } \\
\text { agarra! ¡Si le está } \\
\text { cogiendo el paquete! }\end{array}$ & $\begin{array}{l}\text { She's going for his } \\
\text { balls. }\end{array}$ \\
\hline
\end{tabular}

The vulgarity of Ana's comment is reflected in the translation by means of the coarse expression "to go for one's balls", to which Pepa replies:

\begin{tabular}{|l|l|l|}
\hline FILM AND YEAR & SOURCE TEXT & TARGET TEXT \\
\hline Mujeres al borde & -Hombre, eso no creo. Se & I think she's just \\
\hline
\end{tabular}




\begin{tabular}{|l|l|l|}
\hline $\begin{array}{l}\text { de un ataque de } \\
\text { nervios (1988) }\end{array}$ & $\begin{array}{l}\text { agarra para no caerse, } \\
\text { que no nos caerá esa } \\
\text { breva. }\end{array}$ & trying to hang on. \\
\hline
\end{tabular}

We see here that the expression "caer una breva" has been left out in the subtitles, as the translator has decided not to use an expression like "no such luck", for instance, even though it would not have the same colloquial strength as the original. While this omission does not really detract from the flow of the action, it is another example that shows the numerous omissions of translations of slang words and colloquialisms in these films. ¿Atame! (1988) deals with the life of Ricky, a disturbed young man who is released from the mental institution where he has lived for most of his life. He immediately goes out in search of a woman he once met and had sex with. This woman, Marina, is an actress who has had trouble with drugs. Ricky kidnaps her in her own apartment, as he wants her to fall in love with him, so he can have the family he had always dreamt of. Ricky has a particular speech pattern full of slang and colloquialisms:

\begin{tabular}{|l|l|l|}
\hline FILM AND YEAR & SOURCE TEXT & TARGET TEXT \\
\hline Átame (1988) & $-\ldots$. me lo montaré bien. & I'll manage. \\
\hline & - ¡Mola! & Cool! \\
\hline & $-\ldots$. pero pasaste. & You ignored me! \\
& $\begin{array}{l}\text {-A veces me tiro esos } \\
\text { rollos. }\end{array}$ & $\begin{array}{l}\text { Yeah, sometimes I } \\
\text { show off. }\end{array}$ \\
\hline
\end{tabular}




\begin{tabular}{|c|c|c|}
\hline & -Un puntito ¿eh? & Super, eh? \\
\hline & -Ésta está frita. & She's out cold. \\
\hline & -....estoy apañado. & ....hell. \\
\hline & $\begin{array}{l}\text { - ¡Me has estado dando } \\
\text { largas, ....! }\end{array}$ & You tricked me, ....! \\
\hline
\end{tabular}

All this slang and colloquial language is really difficult to translate. Thus the subtitles do not reflect the original register of the character. The problem is that the original flavor of the film is threatened by neutral translations, and the response of the target audience will differ greatly from that of the source one. The same could be said about Marina's and Lola's comments:

\begin{tabular}{|c|c|c|}
\hline FILM AND YEAR & SOURCE TEXT & TARGET TEXT \\
\hline \multirow[t]{5}{*}{ Átame (1988) } & $\begin{array}{l}\text {-Voy a meterles } \\
\text { caña...(Lola) }\end{array}$ & $\begin{array}{l}\text { I'll have to keep after } \\
\text { them. }\end{array}$ \\
\hline & $\begin{array}{l}\text {-Por un tubo (referring } \\
\text { to blood) (Lola) }\end{array}$ & Lots. \\
\hline & $\begin{array}{l}\text {-¡Pues estamos } \\
\text { apañadas! (Lola) }\end{array}$ & What a mess! \\
\hline & $\begin{array}{l}\text {-Se ha mosqueado } \\
\text { (Marina) }\end{array}$ & She's pissed. \\
\hline & $\begin{array}{l}\text {-¡Joder, qué carrerón! } \\
\text { (Marina) }\end{array}$ & What a career! \\
\hline
\end{tabular}




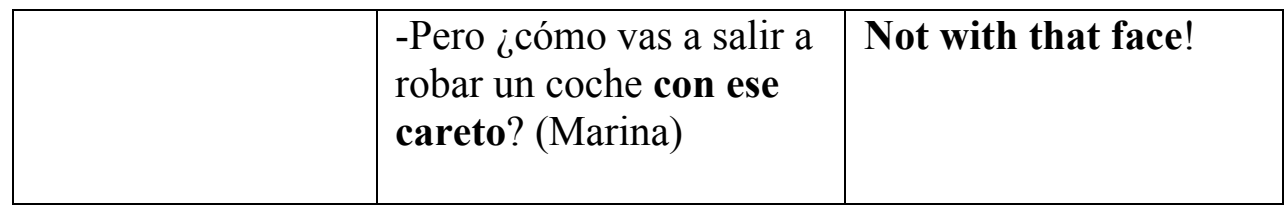

The word "pela" is colloquial for "peseta", and it appears several times all over the film, the first time at a pastry shop:

\begin{tabular}{|l|l|l|}
\hline FILM AND YEAR & SOURCE TEXT & TARGET TEXT \\
\hline Átame (1988) & $\begin{array}{l}\text {-600 pelas, cariño (Shop } \\
\text { assistant) }\end{array}$ & 60 pelas. \\
\hline & $\begin{array}{l}\text {-Mamá ¿qué son 'pelas'? } \\
\text { (Boy) }\end{array}$ & What are pelas, Mom? \\
\hline & -Pesetas, cariño (Mother) & Pesetas, darling. \\
\hline
\end{tabular}

Besides the mistake shown in the first subtitle - 60 instead of 600 -, the foreign audience finds two words that have not been translated in the subtitles: "pelas" and "pesetas". I believe that the outdated Spanish "peseta" may be known to the foreign audience, and I agree with the idea of keeping the original currency instead of an adaptation for the target audience. On the other hand, "pelas" may not be as well-known; so the most suitable option would be to keep both words in the original language - as the translator has done. By means of these words the translator is preserving the film's cultural identity, while enriching the target culture. Later on "pelas" appears again:

\begin{tabular}{|l|l|l|}
\hline FILM AND YEAR & SOURCE TEXT & TARGET TEXT \\
\hline Átame (1988) & $-¿$ Una bolsa de 5000 & A 5000 peseta bag? \\
\hline
\end{tabular}




\begin{tabular}{|l|l|l|}
\hline & pelas? (Drug-dealer) & \\
\hline & $\begin{array}{l}\text {-Dame las 5000 pelas } \\
\text { (Rosy) }\end{array}$ & Give me the dough. \\
\hline & $\begin{array}{l}\text {-A ver, enséñame la } \\
\text { pasta que llevas (Rosy) }\end{array}$ & You got any dough? \\
\hline
\end{tabular}

In the first example, the translator has again included the word "peseta" instead of "pela", whereas in the second one, the option has been to use "dough" without the '5000' to convey the message and the register of the ST. On the other hand, the equivalent translation of "dough" would be "pasta" as in the third example.

There are some characters like Berta, Marina's doctor, whose comments contain slang and colloquial expressions:

\begin{tabular}{|l|l|l|}
\hline FILM AND YEAR & SOURCE TEXT & TARGET TEXT \\
\hline Átame (1988) & $\begin{array}{l}\text {-Más sola que la una, } \\
\text { hija mía. }\end{array}$ & Very much alone! \\
\hline & $\begin{array}{l}\text {-Uy, 'cuidao' con la } \\
\text { mesa que es muy } \\
\text { traicionera. }\end{array}$ & $\begin{array}{l}\text { Careful! The table } \\
\text { has a mind of its own. }\end{array}$ \\
\hline & $\begin{array}{l}\text {-Pues estáis buenos los } \\
\text { dos... }\end{array}$ & You're quite a pair. \\
\hline
\end{tabular}

Berta's particular speech full of colloquialisms is successfully rendered in the subtitles (especially in the second one). The way she speaks is humorous in itself, and the pictorial information adds to it. Berta is a doctor who has helped Marina get over a drug habit, and she is now offering her a joint. The words of the drug-dealer, played by Rosy de Palma, exhibits the same type of speech: 


\begin{tabular}{|l|l|l|}
\hline FILM AND YEAR & SOURCE TEXT & TARGET TEXT \\
\hline Átame (1988) & $\begin{array}{l}\text {-Estad al loro que voy a } \\
\text { ver. }\end{array}$ & $\begin{array}{l}\text { Stick around. I'll } \\
\text { check. }\end{array}$ \\
\hline & $\begin{array}{l}\text {-Soy la del palo de la } \\
\text { otra noche. }\end{array}$ & You roughed me up! \\
\hline
\end{tabular}

It is De Palma's social condition that accounts for her "Cheli" language. The first example reproduces the original message without keeping the informal expression "estar al loro" ("to keep one's eyes open") by means of a colloquial equivalent in the TT. In the second example, even though the translation is not an exact equivalent, it successfully conveys the colloquialism and message of the ST.

The protagonists of Tacones lejanos (1991) belong to a socially respectable family: Becky del Páramo, a famous singer, her daughter Rebeca who is a news hostess, and judge Domínguez. Throughout the film colloquialisms and slang can be heard. Becky's personality shows a certain lack of integrity: she seems to be a cold woman, who has left her only daughter in Spain to go to Mexico for a short time. But this short time becomes an eternity, as she does not come back to Spain until her daughter, Rebeca, is already grown-up. We see in her words and actions that Becky is conceited and calculates her words and actions. While the source audience is aware of her use of Mexican colloquialisms adopted because of her long stay in that country, the subtitles only reflect the message of the original. The use of different types of standard Spanish is not reflected in the subtitles, and although it does not really ruin the final text, it does deprive the target audience of some of the most distinctive features of Becky's personality: 


\begin{tabular}{|l|l|l|}
\hline FILM AND YEAR & SOURCE TEXT & TARGET TEXT \\
\hline $\begin{array}{l}\text { Tacones lejanos } \\
(1991)\end{array}$ & $\begin{array}{l}\text {-Estás reguapa con ese } \\
\text { Chanel. }\end{array}$ & That Chanel suits you, \\
\hline & $\begin{array}{l}\text {-Me enteré de purita } \\
\text { casualidad. }\end{array}$ & $::::::::::$ \\
\hline
\end{tabular}

Either the translator has decided not to focus on these colloquialisms and simply to render the original message -as in the first example-, or to omit the whole comment, as is the case in the second example. By contrast Rebeca uses Spanish colloquialisms:

\begin{tabular}{|c|c|c|}
\hline FILM AND YEAR & SOURCE TEXT & TARGET TEXT \\
\hline \multirow[t]{5}{*}{$\begin{array}{l}\text { Tacones lejanos } \\
\text { (1991) }\end{array}$} & $\begin{array}{l}\text {-Pensé que preferías que } \\
\text { no hubiera follón. }\end{array}$ & But I thought.... \\
\hline & $\begin{array}{l}\text { - ¡A la hija le da un } \\
\text { apuro! }\end{array}$ & The daughter refuses. \\
\hline & -¡Eres una negada! & You're worthless! \\
\hline & $\begin{array}{l}-¿ \text { Cómo te atreves a } \\
\text { poner tus dedazos...? }\end{array}$ & How dare you distort? \\
\hline & $\begin{array}{l}\text { - } i \ldots . . \text { con el jamacuco } \\
\text { que tengo! }\end{array}$ & $\begin{array}{l}\text { when I'm so stressed } \\
\text { out? }\end{array}$ \\
\hline
\end{tabular}

But these are not shown in the subtitles. This might suggest that the translator considered Rebeca's speech pattern to be of little significance for the target audience, while the source spectator hears her natural discourse full of colloquial language. 
Judge Domínguez's mother uses those colloquialisms that are especially common among old people. Sick and bedridden for many years, she looks for news about Becky del Páramo in magazines, and then glues her clippings into albums. Here are some of her remarks:

\begin{tabular}{|l|l|l|}
\hline FILM AND YEAR & SOURCE TEXT & TARGET TEXT \\
\hline $\begin{array}{l}\text { Tacones lejanos } \\
(1991)\end{array}$ & $\begin{array}{l}\text {-Porque últimamente no } \\
\text { me encuentro muy } \\
\text { católica. }\end{array}$ & I feel erratic lately. \\
\hline & $\begin{array}{l}\text {-Anda, dame las tijeritas } \\
\text { que tengo en el altarillo } \\
\text { ese, corazón. }\end{array}$ & $\begin{array}{l}\text { Hand me the scissors, } \\
\text { son. }\end{array}$ \\
\hline & $\begin{array}{l}\text {-Y la hija iqué cara de } \\
\text { sota tiene! }\end{array}$ & $\begin{array}{l}\text { The daughter looks } \\
\text { like a sourpuss. }\end{array}$ \\
\hline
\end{tabular}

"No encontrase católico/a" (not to feel well) is a colloquial expression used mostly by older people, but the TT does not keep the meaning of the original. The use of the adjective "erratic" ("imprevisible, voluble, irregular") has nothing to do with the meaning of the ST. Neither does the second example, in which she says that her scissors are in "el altarillo", a little altar - a reference that the translator has decided to omit. Similarly, the vocative by which the mother addresses her son, "corazón" ("heart"), is translated with the neutral word "son" ("hijo"), which definitely does not convey the tenderness of the source. "Tener cara de sota" in the last example has been translated as "to look like a sourpuss", which certainly keeps the original content, and the colloquial sense of the ST. Here the source expression is a reference to the suit of "clubs" in a deck of cards. The "sota" would be the corresponding queen, and the expression "tener 
cara de sota (de bastos)" is used to refer to somebody who looks angry. The cultural dimension of such an expression makes it impossible for the translator to find an equivalent in English.

Rebeca is accused of murdering her husband and is then taken to prison. There she socializes with different female prisoners belonging to a variety of social classes, mostly disadvantaged ones. Their language is full of slang and colloquialisms, like the conversation between the two prisoners, Luisa and Chon, about money:

\begin{tabular}{|l|l|l|}
\hline FILM AND YEAR & SOURCE TEXT & TARGET TEXT \\
\hline $\begin{array}{l}\text { Tacones lejanos } \\
(1991)\end{array}$ & -Diez mil pelas (Luisa) & One hundred. \\
\hline & $\begin{array}{l}\text {-Oye, que a mí me costó } \\
\text { quince mil (Chon) }\end{array}$ & I paid 150 for it. \\
\hline & $\begin{array}{l}\text {-Es verdad. Diecisiete } \\
\text { mil, perdona (Luisa) }\end{array}$ & Sorry, 170. \\
\hline
\end{tabular}

In this film the translator has opted for a conversion in dollars at that time, without displaying the currency itself. As for the translation of currency, the translators of Almodóvar's films use either the cultural non-equivalent in the subtitles, or a colloquial equivalent, or they give the figure of the conversion in dollars, for example.

Paula, one of the social workers in the prison holds a conversation with one of the prisoners who is a drug-dealer. She has a very peculiar way of speaking: 


\begin{tabular}{|l|l|l|}
\hline FILM AND YEAR & SOURCE TEXT & TARGET TEXT \\
\hline $\begin{array}{l}\text { Tacones lejanos } \\
(1991)\end{array}$ & $\begin{array}{l}\text {-Era de un tío que la } \\
\text { palmó. }\end{array}$ & Some guy who died. \\
\hline & $\begin{array}{l}\text {-Cuando él trapicheaba } \\
\text { cogieron a muchos }\end{array}$ & $\frac{\text { Lots of us got caught }}{\text { when he was pushing. }}$ \\
\hline
\end{tabular}

In the first example the slang language ("tío", "palmar") is not rendered in the translation, so the target audience does not perceive that the prisoner's speech pattern is as different from that of the other characters in the film. However, in the second example the slang expression "to push" does faithfully transmit the register of the original. Paula's tone is more educated than that of the other prisoners, even though she does use a slang word:

\begin{tabular}{|l|l|l|}
\hline FILM AND YEAR & SOURCE TEXT & TARGET TEXT \\
\hline $\begin{array}{l}\text { Tacones lejanos } \\
(1991)\end{array}$ & $\begin{array}{l}\text {-La chupa roja que lleva } \\
\text { era de él. Se la regalé yo. }\end{array}$ & f bought that jacket \\
\hline
\end{tabular}

"Chupa" refers to a leather jacket, but the subtitle just reflects the neutral word "jacket". By using slang Rebeca tries to adopt a lower class term in an effort to adapt to the speech of the other prisoners. But the target audience is not aware of this as it is not rendered in the subtitles. Another example which may be humorous for the original audience is uttered by a gipsy prisoner, who instead of the word "megafonía" ("loudspeakers") says "agrofonía". This humorous malapropism is not kept in the translation, and therefore does not produce any humorous effect in the target audience. The translation only offers a replacement of the equivalent for 
"loudspeaker" with "that speaking thing" - an attempt to reflect the linguistic difficulty of the speaker without succeeding:

\begin{tabular}{|l|l|l|}
\hline FILM AND YEAR & SOURCE TEXT & TARGET TEXT \\
\hline $\begin{array}{l}\text { Tacones lejanos } \\
(1991)\end{array}$ & $\begin{array}{l}\text {-¡No sabes que te están } \\
\text { llamando allá arriba, en } \\
\text { la agrofonía ésta! }\end{array}$ & $\begin{array}{l}\text { That speaking thing } \\
\text { is calling you! }\end{array}$ \\
\hline
\end{tabular}

In Kika (1993) the protagonist is a humorous character in virtue mostly of her style of speaking. Her comments are hilarious, full of colloquialisms, and uttered in quite a high pitched voice:

\begin{tabular}{|l|l|l|}
\hline FILM AND YEAR & SOURCE TEXT & TARGET TEXT \\
\hline Kika (1993) & $\begin{array}{l}\text {-...a una mujer con el ojo } \\
\text { caído así para abajo, tipo } \\
\text { perro pachón. }\end{array}$ & $\begin{array}{l}\text {..to one with a spaniel } \\
\text { eye. }\end{array}$ \\
\hline & $\begin{array}{l}\text {-Yo he tenido la manga } \\
\text { muy ancha. }\end{array}$ & $\begin{array}{l}\text { I haven't been very } \\
\text { selective. }\end{array}$ \\
\hline & $\begin{array}{l}\text {-Tu padrasto también } \\
\text { para darle de comer } \\
\text { aparte. }\end{array}$ & $\begin{array}{l}\text { Your stepfather } \\
\text { is another ball-game. }\end{array}$ \\
\hline & $\begin{array}{l}\text {-Eso sí, en la cama muy } \\
\text { bien, tiene mucho } \\
\text { morbo, las cosas como } \\
\text { son. }\end{array}$ & $\begin{array}{l}\text { Great in bed, very } \\
\text { sexy. }\end{array}$ \\
\hline & \begin{tabular}{l}
-iQué morro tiene! \\
\hline
\end{tabular} & He's so cheeky! \\
\hline
\end{tabular}


But the colloquialisms of these examples have not been kept in the TT, thus losing all trace of their humor. It is the impossibility of finding a close natural equivalent in the TL that accounts for this loss. Extraordinarily funny for the source audience is the conversation Kika holds with her cleaning lady Juana, who is not very pretty:

\begin{tabular}{|l|l|l|}
\hline FILM AND YEAR & SOURCE TEXT & TARGET TEXT \\
\hline Kika (1993) & $\begin{array}{l}\text {-Si fueras menos cardo, } \\
\text { ahora que se llevan las } \\
\text { caras raras, hasta podrías } \\
\text { ser modelo. }\end{array}$ & $\begin{array}{l}\text { If you were less rough, } \\
\text { you could } \\
\text { be a model with that } \\
\text { face. }\end{array}$ \\
\hline & -iQué heavy eres! & You are so heavy! \\
\hline
\end{tabular}

When Kika tells Juana frankly that she is a bit "cardo", she uses a colloquialism (about a thistle) to refer to Juana's appearance. The TT does not convey the humor, as the word "rough" does not sound as funny as the original. Kika uses the Anglicism "heavy" in the ST to refer to Juana's attitude, and the same word has been kept in the TT. There are more examples of Kika exhibiting these colloquialisms and humor:

\begin{tabular}{|l|l|l|}
\hline FILM AND YEAR & SOURCE TEXT & TARGET TEXT \\
\hline Kika (1993) & $\begin{array}{l}\text {-..no me paso el día run- } \\
\text { run, run-run, dándole a } \\
\text { la lavadora. }\end{array}$ & $\begin{array}{l}\text {...don't spend } \\
\text { all day turning it over } \\
\text { in my head. }\end{array}$ \\
\hline & $\begin{array}{l}\text {-...me estás poniendo } \\
\text { perdida de babas. }\end{array}$ & Stop drooling on me. \\
\hline
\end{tabular}




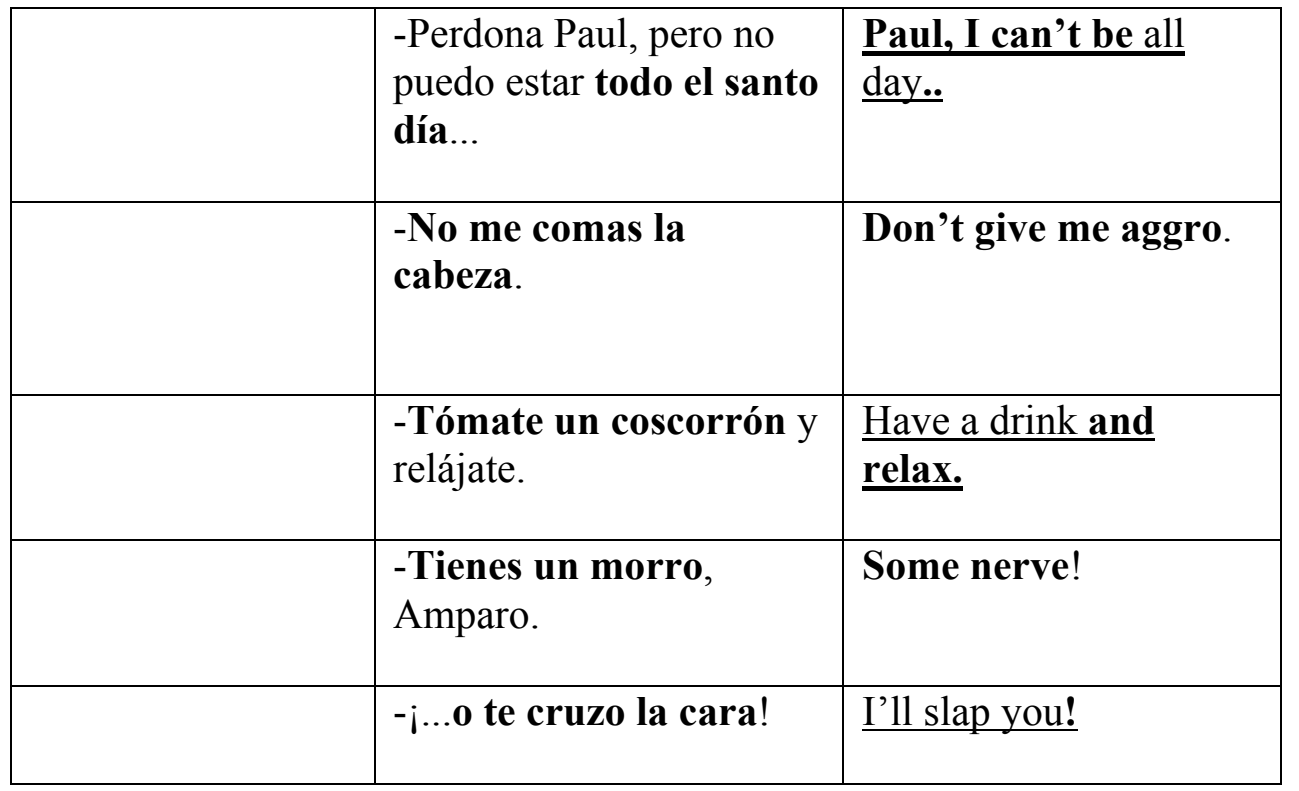

Here we see that there is no trace of any of the original humor left in the subtitles, as it is very difficult for the audiovisual translator to convey the exact comical sense and content of the original. Not only is it difficult, it is sometimes impossible to translate a humorous comment made by a character, and to produce the same effect in the target version. According to Nida's concept of dynamic equivalence based upon the "equivalent effect principle", the main concern for the translator is to create a translation that produces an identical effect on the TT reader (or spectator) that is identical to "the effect which is understood to have existed in the response of the original hearers" (Nida 1964: 7). As Nida points out, this effect sets up the meaning of the ST. Therefore, in these translations, the equivalent for the most part is not achieved. In Kika the translator has chosen a natural and fluid style in the TL, and has left aside the stylistic characteristics of the ST, the domestication of the translation resulting in the loss of the original humor and speech pattern. 
Carne trémula (1997) also includes numerous examples of slang and colloquial language. Víctor, one of the protagonists, has been released after several years in prison:

\begin{tabular}{|c|c|c|}
\hline FILM AND YEAR & SOURCE TEXT & TARGET TEXT \\
\hline \multirow[t]{10}{*}{$\begin{array}{l}\text { Carne trémula } \\
\text { (1997) }\end{array}$} & $\begin{array}{l}\text {-Ahora estoy enrollado } \\
\text { con el Génesis. }\end{array}$ & $\begin{array}{l}\text { Right now, I'm into } \\
\text { Genesis. }\end{array}$ \\
\hline & $\begin{array}{l}\text {-Creerás que estoy } \\
\text { majara ¿verdad? }\end{array}$ & $\begin{array}{l}\text { You must think I'm } \\
\text { cracked. }\end{array}$ \\
\hline & -Buen rollo. & Cool, dude. \\
\hline & -Mejor rollo todavía. & Even cooler. \\
\hline & -¡Qué guay! & Great! \\
\hline & -¡...qué palo! & ..., what a putdown! \\
\hline & $\begin{array}{l}\text {-...te quedarías colgada } \\
\text { de mí. }\end{array}$ & you would fall for me. \\
\hline & $\begin{array}{l}\text {-Es que he tenido un } \\
\text { movidón en casa... }\end{array}$ & I'd a problem at home. \\
\hline & $\begin{array}{l}\text {-Solamente me estoy } \\
\text { aturdiendo. }\end{array}$ & I'm getting tipsy. \\
\hline & $\begin{array}{l}\text {-Piérdete con tu churri } \\
\text { ¿eh? }\end{array}$ & Go see your girl. \\
\hline
\end{tabular}

Víctor's social condition as the son of a prostitute justifies his speech style. Except for examples two, three, and four, where the 
$\underline{\text { translations achieve the equivalent effect by means of colloquialisms, }}$ the rest do not transmit the character's speech style; they simply state the content of the ST. However, there are other characters in high social positions whose speech also contains slang and colloquial expressions. Sancho, a policeman, is one of them:

\begin{tabular}{|c|c|c|}
\hline FILM AND YEAR & SOURCE TEXT & TARGET TEXT \\
\hline \multirow[t]{5}{*}{$\begin{array}{l}\text { Carne trémula } \\
\text { (1997) }\end{array}$} & $\begin{array}{l}\text {-Es la única manera de } \\
\text { que una mujer no te la } \\
\text { pegue. }\end{array}$ & $\begin{array}{l}\text { It's the only way } \\
\text { a woman won't cheat. }\end{array}$ \\
\hline & $\begin{array}{l}\text {-..mientras yo estoy } \\
\text { currando. }\end{array}$ & ...while I'm working. \\
\hline & $\begin{array}{l}\text {-...o voy a hacer tortilla } \\
\text { francesa con ellos. }\end{array}$ & $\begin{array}{l}\text { or I'll bounce them off } \\
\text { the wall! }\end{array}$ \\
\hline & -¡Que se te va la bola! & You've flipped! \\
\hline & $\begin{array}{l}\text {-...con el tute que te } \\
\text { pegas bailando. }\end{array}$ & $\begin{array}{l}\text {...you've been busting } \\
\text { your ass dancing. }\end{array}$ \\
\hline
\end{tabular}

The first two examples do not achieve the equivalent effect due to the neutral register that does not correspond to that of the ST. The third example exhibits a cultural referent "tortilla francesa" whose closest translation would have been "I'd make scramble eggs out of them". Instead, the translation shows an equivalent expression in which there is no trace of the "meal" present in the original. The fourth example shows the closest equivalent for the source expression. However, the last of these examples presents a different translation. The character has to dance for a living and works really hard at it, and as a result her husband is worried because she works so much. 
But while the meaning of the ST is not offensive, the expression in the TT is a little vulgar.

The character of Clemen, who works at Elena's nursing home, exhibits a speech pattern full of slang words and colloquial expressions:

\begin{tabular}{|c|c|c|}
\hline FILM AND YEAR & SOURCE TEXT & TARGET TEXT \\
\hline \multirow[t]{5}{*}{$\begin{array}{l}\text { Carne trémula } \\
\text { (1997) }\end{array}$} & $\begin{array}{l}\text {-Le voy a tener que dar } \\
\text { otro sablazo a la Elena } \\
\text { al final. }\end{array}$ & $\begin{array}{l}\text { We'll have to hit } \\
\text { Elena } \\
\text { for money again. }\end{array}$ \\
\hline & $\begin{array}{l}\text {-Y no sé tía, a mi me ha } \\
\text { 'dao' buen rollito. }\end{array}$ & $\begin{array}{l}\text { I took a real shine to } \\
\text { him. }\end{array}$ \\
\hline & $\begin{array}{l}\text {-Se lo están pasando } \\
\text { pipa. Están flipando. }\end{array}$ & $\begin{array}{l}\text { They're having a ball. } \\
\text { They're crazy about } \\
\text { him. }\end{array}$ \\
\hline & $\begin{array}{l}\text {-La que corta el } \\
\text { bacalao. }\end{array}$ & She's the big boss. \\
\hline & $\begin{array}{l}\text {-La italiana está 'forrá'. } \\
\text { Que se estire. }\end{array}$ & $\begin{array}{l}\text { That Italian woman's } \\
\text { loaded. }\end{array}$ \\
\hline
\end{tabular}

Again, the speech of the character is not reproduced in the translations, even though they reflect the original content. In the third example the expression "to have a ball" is equivalent in meaning and register to the Spanish "pasárselo pipa". But in the last example the subtitles show an omission of the colloquialism "que se estire".

Looking at the totality of Almodóvar's work, there seems to be a gradual decrease in slang and colloquialisms in his films, as if 
the director had undergone a gradual refinement. Nevertheless, Todo sobre mi madre (1999), the last of his films to be analyzed in this thesis, has several examples of colloquialisms. One of the characters, Agrado, a retired transsexual prostitute, is a good example of this slang-filled style, as well as a good vehicle for the humor in the film:

\begin{tabular}{|c|c|c|}
\hline FILM AND YEAR & SOURCE TEXT & TARGET TEXT \\
\hline \multirow[t]{6}{*}{$\begin{array}{l}\text { Todo sobre mi } \\
\text { madre (1999) }\end{array}$} & $\begin{array}{l}\text {-Dieciocho años sin } \\
\text { decir ni mú, ni una } \\
\text { mala carta, ni una mala } \\
\text { llamada... }\end{array}$ & $\begin{array}{l}18 \text { years, not a word, } \\
\text { not a letter, not a } \\
\text { fucking call. }\end{array}$ \\
\hline & $\begin{array}{l}\text {-...con tó lo que se } \\
\text { mete... }\end{array}$ & $\begin{array}{l}\text { with all the shit she } \\
\text { takes. }\end{array}$ \\
\hline & $\begin{array}{l}\text {-... aunque solo sea pá } \\
\text { hincharme de llorá... }\end{array}$ & $\begin{array}{l}\text {...even if it's only } \\
\text { to cry my eyes out... }\end{array}$ \\
\hline & $\begin{array}{l}\text { ¿Dónde voy con este } \\
\text { careto? }\end{array}$ & $\begin{array}{l}\text {..Where can I go } \\
\text { with a mug like this? }\end{array}$ \\
\hline & $\begin{array}{l}\text { - ¿No os he seguido la } \\
\text { corriente como una } \\
\text { inglesa, para que Doña } \\
\text { Sumé no se coscara de } \\
\text { nada? }\end{array}$ & $\begin{array}{l}\text { I play along like an } \\
\text { English lady } \\
\text { so she wouldn't catch } \\
\text { on! }\end{array}$ \\
\hline & $\begin{array}{l}\text {-Hay que cogernos el } \\
\text { punto. }\end{array}$ & $\begin{array}{l}\text { You have to get to } \\
\text { know us. }\end{array}$ \\
\hline
\end{tabular}

Agrado's chice of words and expressions as well as her strong Andalusian accent - as will be seen in section 3.2.6. -, make for extremely humorous comments. Yet the natural flow of her language is not well transmitted in the translations, even though some of them 
make a good attempt to convey the peculiarities of her character. The first and second examples display an offensive translation, while the STs do not contain any such vulgarity. Nor is the humor is conveyed in the subtitles.

On the other hand, the protagonist Manuela is a respectable nurse and a friend of Agrado's. Her speech generally does not present as many colloquialisms and slang as Agrado's, with a few exceptions such as the following:

\begin{tabular}{|c|c|c|}
\hline FILM AND YEAR & SOURCE TEXT & TARGET TEXT \\
\hline \multirow[t]{3}{*}{$\begin{array}{l}\text { Todo sobre mi } \\
\text { madre (1999) }\end{array}$} & -¡Estás hecha un Cristo! & ::::::::::: \\
\hline & $\begin{array}{l}\text {-Él se pasaba el día } \\
\text { embutido en un bikini } \\
\text { microscópico, tirándose } \\
\text { todo lo que pillaba... }\end{array}$ & $\begin{array}{l}\text { He spent the day in a } \\
\text { tiny bikini } \\
\text { screwing everything } \\
\text { he could... }\end{array}$ \\
\hline & $\begin{array}{l}\text {-Está puesta hasta las } \\
\text { trancas. }\end{array}$ & She's bombed. \\
\hline
\end{tabular}

The omission of the exclamation with religious connotations of the first example contrasts with the mostly successful equivalence of the rest of the examples. The reason for such an omission is hard to explain, since there is an equivalent for the expression in English ("to be in a terrible mess"), even though it does not have any religious component. Here time and space constraints do not seem to account for the omission, as it is an isolated comment that would fit perfectly in the space allowed for the subtitle.

Nina is a junkie actress who has a homosexual relationship with her colleague, Huma. Unlike Huma, the drug-addict Nina uses slang and colloquial expressions: 


\begin{tabular}{|l|l|l|}
\hline FILM AND YEAR & SOURCE TEXT & TARGET TEXT \\
\hline $\begin{array}{l}\text { Todo sobre } m i \\
\text { madre (1999) }\end{array}$ & $\begin{array}{l}\text {-Bueno ial loro con la } \\
\text { puerta! }\end{array}$ & $\begin{array}{l}\text { All right! } \\
\text { Keep an eye on the } \\
\text { door! }\end{array}$ \\
\hline & $\begin{array}{l}\text {-A lo mejor a mi también } \\
\text { me mola. }\end{array}$ & Maybe I'll like it too. \\
\hline & $\begin{array}{l}\text {-Al público le } \\
\text { encanta...no ves que } \\
\text { hago de preñada. Se } \\
\text { creen que es por el papel } \\
\text { y flipan. }\end{array}$ & $\begin{array}{l}\text { The audience loves it. } \\
\text { pregnant. }\end{array}$ \\
\hline
\end{tabular}

But Nina's colloquial style is entirely lost in the subtitles. Rather than reflecting her rudeness, the English version comes across as simply neutral. Thus the target audience cannot experience the character in the same way as the source audience does; it is as if the character in the subtitles were a very different one.

Typically, the slang and colloquial language present in Almodóvar's films - more predominant in some films than in others - is linked to the characters' social condition. The speech styles of these characters reflect and portray the world in which they live. Sometimes the non-existence of slang and "Cheli" equivalents in English accounts for the standardization and neutralization of the subtitles. Most translations seem to convey the information present in the ST, but fail to reproduce subtleties of register, style or dialect. The colloquial force of the ST, rich in the vernacular language, is generally lost in the translation. On the other hand, some subtitles achieve the equivalent effect by means of a fluid and colloquial style. The omission of some words and expressions is difficult to explain, in 
view of the basic tendency in most translations either to respect the register, or simply to convey the information of the ST.

As regards inconsistencies in translations, some TTs display more offensive and unrefined language than that of the ST, and others present wrong translations probably associated with the translator's unawareness of the SL meaning. There are also inconsistencies in the translation of the same word within the same film ("talego" as "dough", "monev", "::::::::"), which could have been avoided by using the same translation in every instance. The neutralizations and omissions of slang words and expressions may be accounted for by the translator's feeling that its rendering would not be relevant for the plot. However, it has been demonstrated that such strategies lead to the loss of the film's cultural identity and spirit. It can be said that, on the whole, the attempt to translate the humor of the characters has for the most part failed. The hilarity that these characters evoke in the source audience is not likelv to be reproduced by reading the subtitles. In general, by means of domestication translators have chosen a natural and fluid style in the TT, thereby sacrificing the stylistic traits that characterize the speech of most of the characters.

\subsubsection{Accent}


Barcelona, que hable como en

Barcelona."

Pedro Almodóvar, in Nuria

Vidal, El cine de Pedro

Almodóvar.

Accents provide a wealth of information about the speaker both in

life generally and in film specifically. (Bravo 2002: 208)

Accent is very significant in Peninsular Spanish due to the various dialects and languages spoken in such a small country, e.g. Basque, Catalan and Galician. The speech of some of the characters in Almodóvar's films is characterised by social and geographical varieties of the Spanish language. Yet, Almodóvar "chooses not to represent the pluralities of national identities and languages which is contemporary Spain" (Allinson 2001: 44), and therefore he does not commit himself to the problems related to them. Instead, the director presents characters that have an Andalusian accent, considered a humorous accent in Spain.

The linguistic idiosyncrasies present some characters' speeches are by and large impossible to reproduce in the TT: "Accents and pronunciation are tricky to render in subtitles, and yet they may be important. Luckily, marked accents often go hand in hand with marked vocabulary" (Díaz Cintas \& Remael 2007: 194). The regional accent of characters such as Juani, Candela, or Agrado cannot be represented in subtitles in a manner easily understood by the target audience. Only an audience with a good knowledge of Spanish can tell that there is something different in the way a particular character speaks, as the presence of the original 
soundtrack helps in this regard ${ }^{32}$. By contrast, the representation of a regional or foreign accent in a dubbed film is easier to achieve, and audiovisual translators usually resort to presenting accents that exist in the TL in order to represent the source ones.

In ¿Qué he hecho yo para merecer esto? (1984), Juani has a strong Andalusian accent, and her interventions are full of colloquial expressions. Her bitter and disrespectful words produce shock in the Spanish audience, as she touches on all sexual and scatological taboos. And even though her role is that of an abusive and cruel mother, her strong accent and her use of southern rural expressions contribute to the humor of certain scenes. Addressing her only child, Vanesa:

\begin{tabular}{|l|l|l|}
\hline $\begin{array}{l}\text { FILM AND } \\
\text { YEAR }\end{array}$ & SOURCE TEXT & TARGET TEXT \\
\hline $\begin{array}{l}\text { iQué he hecho yo } \\
\text { para merecer esto? } \\
\text { (1984) }\end{array}$ & $\begin{array}{l}\text {-Que te he disho que no } \\
\text { hagah mohineh. }\end{array}$ & $\underline{\text { Don't make faces! }}$ \\
\hline & $\begin{array}{l}\text {-iQuinqui, que ereh una } \\
\text { quinqui! }\end{array}$ & She drives me nuts! \\
\hline & $\begin{array}{l}\text {-¡Oshe, qué mala } \\
\text { condisión tiene! }\end{array}$ & Damn brat! \\
\hline
\end{tabular}

While the first example displays an equivalent expression, even though there is no trace of accent involved, the following two do not even exhibit equivalents in the TT.

\footnotetext{
${ }^{32}$ In the following examples I have tried to represent accentual features orthographically.
} 
The way Juani addresses Vanesa is always offensive and cruel, and her threats towards her daughter are numerous, but her cruelty is diminished in the TT:

\begin{tabular}{|l|l|l|}
\hline $\begin{array}{l}\text { FILM } \\
\text { YEAR }\end{array}$ & $\underline{\text { SOURCE TEXT }}$ & TARGET TEXT \\
\hline $\begin{array}{l}\text { ¿Qué he hecho yo } \\
\text { para merecer esto? } \\
\text { (1984) }\end{array}$ & $\begin{array}{l}\text {-No te creah que te vah a } \\
\text { quedah tú de rositah. }\end{array}$ & :.:.:.:.:::: \\
\hline & $\begin{array}{l}\text {-iCómo le mensiones } \\
\text { otra veh te cruso la cara! }\end{array}$ & $\begin{array}{l}\text { Don't you mention } \\
\text { him again! }\end{array}$ \\
\hline & $\begin{array}{l}\text {-Eah, lo disho ¡Cómo te } \\
\text { muevah te ehtampo } \\
\text { contra la paréh! }\end{array}$ & $\begin{array}{l}\text { If you move, I'll } \\
\text { smash you } \\
\text { against the wall! }\end{array}$ \\
\hline & $\begin{array}{l}\text {-iMardita sea tu ehtampa } \\
\text { puñalera! }\end{array}$ & Goddam you!.... \\
\hline
\end{tabular}

The whole ST has been omitted in the first example, and half the second one ("o te cruzo la cara") has remained untranslated. The third one displays an equivalent expression, even though the expression "eah, lo dicho" has not been translated ("as I said"). The impossibility of finding an exact equivalent for this particular form of cursing has possibly led the translator to include an English curse as well, even though the regional characteristic is lost. Juani's bad manners also show when she talks with other characters, such as her neighbor Cristal:

\begin{tabular}{|c|c|c|}
\hline FILM $\quad$ AND & SOURCE TEXT & TARGET TEXT \\
\hline$\underline{\text { YEAR }}$ & & \\
\hline ¿Qué he hecho yo & -Para que lo sepah, yo & Listen, I raise her th \\
\hline
\end{tabular}




\begin{tabular}{|l|l|l|}
\hline $\begin{array}{l}\text { para merecer esto? } \\
(1984)\end{array}$ & $\begin{array}{l}\text { educo a mi niña como me } \\
\text { sale der... Bueno, no } \\
\text { quiero blahfemá. }\end{array}$ & $\begin{array}{l}\text { way I } \\
\text { fucking well please!// } \\
\text { But I don't want to } \\
\text { swear... }\end{array}$ \\
\hline & -¡Y tú a mí, so pendón! & $\begin{array}{l}\text { I'm sick of you too, } \\
\text { slut! }\end{array}$ \\
\hline
\end{tabular}

The anger present in the first example is maintained in the TT by means of the coarse language. While Juani avoids saying the end of the offensive expression "lo que me sale del ....", the TT displays its offensiveness by means of the expression "fucking". The second example also carries the meaning of the ST. Her use of "colourful expressions" - analyzed in section 3.2.1 - and the misuse of religious terms - in section 3.2.4. - are also worth mentioning. Despite Juani's cruelty, these words sound humorous to the original audience, their hilarity being entirely linked to social factors related to her speech:

\begin{tabular}{|l|l|l|}
\hline$\underline{\text { FILM AND }}$ & $\underline{\text { SOURCE TEXT }}$ & TARGET TEXT \\
\hline $\begin{array}{l}\text { ¿Qué he hecho yo } \\
\text { para merecer esto? } \\
\text { (1984) }\end{array}$ & $\begin{array}{l}\text {-¿Y tú por qué no te } \\
\text { meteh la lengua en er } \\
\text { culo? }\end{array}$ & $\underline{\text { Why don't you stick }}$ \\
\hline & $\begin{array}{l}\text {-iMe cago en loh } \\
\text { cáncamoh de lah } \\
\text { sepurturah der Señó! }\end{array}$ & Fucking God Almighty! \\
\hline
\end{tabular}

Even though the TTs preserve the vulgarity and rudeness of the original, the target audience probably does not react in the same way as the source audience would, since the character's accent makes the vulgarity sound comical, while there is no trace of such humor in the translation. 
In La ley del deseo (1987) there is also a character with a strong Andalusian accent, Antonio's mother:

\begin{tabular}{|l|l|l|}
\hline$\underline{\text { FILM }}$ ANA & SOURCE TEXT & TARGET TEXT \\
\hline $\begin{array}{l}\text { La ley del deseo } \\
(1987)\end{array}$ & $\begin{array}{l}\text {-Ya desía yo que ehtabah } \\
\text { mu raro úrtimamente. }\end{array}$ & $\begin{array}{l}\frac{\text { You've been acting }}{\text { strange }} \\
\text { lately. }\end{array}$ \\
\hline & -¡Me vaih a quitá la vía! & It'll be the death of me! \\
\hline & $\begin{array}{l}\text {-Mi hiho no tiene ná que } \\
\text { vé con ese corrompío. }\end{array}$ & $\begin{array}{l}\text { My son isn't involved } \\
\text { in perved business. }\end{array}$ \\
\hline & -No se ha movío de casa. & He stayed home. \\
\hline
\end{tabular}

The fluid colloquial style of her speech is not conveyed in the TTs. Neither is her naturalness, so significant of this character, reflected in the subtitles.

Two of the most humorous characters in Almodóvar's films so far are, in my opinion, Candela (Mujeres al borde de un ataque de nervios) and Agrado (Todo sobre mi madre), both of whom have an Andalusian accent. In Mujeres al borde de un ataque de nervios Pepa has a friend called Candela, played by María Barranco, who is in the apartment where the action takes place:

El personaje es una mezcla deliciosa de ingenuidad y sabiduría, de candor y sexualidad primitiva, a la vez muy infantil pero muy adulta y esta contradicción se refleja en su lenguaje. El hecho de que Andalucía fuera y dentro de España se considere como el área más agrícola y que las sociedades agrícolas se consideran en general como las menos desarrolladas, con menos cultura, menos maleadas por la sociedad de consumo y por lo tanto más inocentes y primitivas hace 
que el acento de Candela sea tan importante para la interpretación y comprensión de su personaje como lo fue el acento polaco de Meryl Streep en su representación de Sophie en Sophie's Choice. (Hart 1994: 266)

The source audience finds out that she is from Málaga, since she mentions it at some point ${ }^{33}$. Her origins are borne out by her strong accent (characterized by ellipses, and the use of the "s" sound ("seseo") to mention two easily recognisable features).

\begin{tabular}{|l|l|l|}
\hline $\begin{array}{l}\text { FILM } \\
\text { YEAR }\end{array}$ & SOURCE TEXT & TARGET TEXT \\
\hline $\begin{array}{l}\text { Mujeres al borde } \\
\text { de un ataque de } \\
\text { nervios (1988) }\end{array}$ & $\begin{array}{l}\text {-Ehtoy sube p'arriba y } \\
\text { baha p'abaho y no sé... }\end{array}$ & $\begin{array}{l}\underline{\text { I don't know which }} \\
\text { end } \\
\text { is up anymore! }\end{array}$ \\
\hline & $\begin{array}{l}\text {-iEh que ehtoy metía en } \\
\text { un apuro mu gordo, } \\
\text { Pepa! }\end{array}$ & $\begin{array}{l}\text { I'm in big trouble, } \\
\text { Pepa! }\end{array}$ \\
\hline $\begin{array}{l}\text {-Cuando se fue yo no } \\
\text { sabía ni su nombre ni ná } \\
\text { de ná. Pero me quedé } \\
\text { corgaíta Mary... }\end{array}$ & $\begin{array}{l}\underline{\text { I didn't know his }} \\
\text { or anything, but after } \\
\text { he left...// }\end{array}$ \\
\hline
\end{tabular}

We see that the translations only display the information of the ST, while the wit and warmth of her speech and her accent are lost in the subtitles. Her interventions are simply hilarious, especially the one when she talks about her brief relationship with a Shiite terrorist:

\footnotetext{
${ }^{33}$ The referent to Málaga, province of Andalucía, is nevertheless not reflected in the TT. This will be dealt in section 3.2.7.
} 


\begin{tabular}{|l|l|l|}
\hline $\begin{array}{l}\text { FILM AND } \\
\text { YEAR }\end{array}$ & SOURCE TEXT & TARGET TEXT \\
\hline $\begin{array}{l}\text { Mujeres al borde } \\
\text { de un ataque de } \\
\text { nervios (1988) }\end{array}$ & $\begin{array}{l}\text {-Porque si eh terrorihta, } \\
\text { viví en continuo peligro, } \\
\text { Pepa, pues se te entrega } \\
\text { musho má que un } \\
\text { hombre cuarquiera. }\end{array}$ & $\begin{array}{l}\frac{\text { Because his life is }}{\text { always in danger// }} \\
\text { than other more intense }\end{array}$ \\
\hline & $\begin{array}{l}\text {-Me puse atacá. Dioh } \\
\text { mío, cómo me puse. }\end{array}$ & $\frac{\text { I flipped }}{\text { I really did. }}$ \\
\hline -iQué pico tiene la Pepa! & Pepa's some talker! \\
\hline
\end{tabular}

But there is no trace of such humor in the TTs, and the result is an insipid text with no dialectal varieties.

One of the most humorous moments in the film, I believe, takes place when two policemen enter Pepa's house and Candela thinks they are coming for her. She is totally terrified and bursts into tears. Pepa tries to pretend that nothing is happening, but the policemen are puzzled about her crving:

\begin{tabular}{|l|l|l|}
\hline $\begin{array}{l}\text { FILM } \\
\text { YEAR }\end{array}$ & SOURCE TEXT & TARGET TEXT \\
\hline $\begin{array}{l}\text { Mujeres al borde } \\
\text { de un ataque de } \\
\text { nervios (1988) }\end{array}$ & $\begin{array}{l}\text {-Nada. Comentábamos el } \\
\text { modelo de la señora... } \\
\text { (Pepa) }\end{array}$ & $\begin{array}{l}\text { Nothing,... just } \\
\text { discussing } \\
\text { the lady's dress. }\end{array}$ \\
\hline & $\begin{array}{l}\text {-Eh horroroso, horroroso } \\
\text { (Candela) }\end{array}$ & It's awful. \\
\hline & $\begin{array}{l}\text {-Bueno, ella es libre de } \\
\text { ponerse el traje que } \\
\text { quiera (Carlos) }\end{array}$ & Maybe she likes it. \\
\hline $\begin{array}{l}\text {-Pero eh horroroso } \\
\text { (Candela) }\end{array}$ & But it's awful. \\
\hline
\end{tabular}


Clearly, the foreign spectator does not enjoy Candela's talk as much as the Spanish spectator does. For her accent and her particular use of language convey most of the humor of her talk, most of which is lost in translation.

Agrado is an extraordinarily witty character. As Almodóvar himself says referring to this character in the script of Todo sobre mi madre (1999): "porque en la película también hay humor $[$... ] mucho humor [...] siempre que aparece la Agrado". She is a transsexual exprostitute with an Andalusian accent, and her natural way of acting and speaking turns farcical with every comment she makes. After being beaten up by one of her clients, Agrado goes to a pharmacy with Manuela, and when she sees that the pharmacist does not want to get too close to the door, Agrado says to her:

\begin{tabular}{|c|c|c|}
\hline $\begin{array}{ll}\text { FILM } & \text { AND } \\
\underline{\text { YEAR }} & \end{array}$ & SOURCE TEXT & TARGET TEXT \\
\hline $\begin{array}{l}\text { Todo sobre mi } \\
\text { madre (1999) }\end{array}$ & -Oye, ven acá p'acá. & Hey, come over here. \\
\hline & $\begin{array}{l}\text {-Que vengah, hombre, } \\
\text { que no te vamoh a comé. }\end{array}$ & $\begin{array}{l}\text { We're not going to eat } \\
\text { you. }\end{array}$ \\
\hline
\end{tabular}

Manuela, who wants some medicine to cure Agrado's injuries, asks her if she has some alcohol at home:

\begin{tabular}{|l|l|l|}
\hline $\begin{array}{l}\text { FILM } \\
\text { YEAR }\end{array}$ & SOURCE TEXT & TARGET TEXT \\
\hline $\begin{array}{l}\text { Todo sobre } m i \\
\text { madre (1999) }\end{array}$ & $\begin{array}{l}\text {-No. Anoshe ehtaba fatá } \\
\text { y me lo bebí. }\end{array}$ & $\begin{array}{l}\text { No, I drank it all last } \\
\text { night. }\end{array}$ \\
\hline
\end{tabular}


What Agrado has at home are these things:

\begin{tabular}{|l|l|l|}
\hline $\begin{array}{l}\text { FILM AND } \\
\text { YEAR }\end{array}$ & SOURCE TEXT & TARGET TEXT \\
\hline $\begin{array}{l}\text { Todo sobre } m i \\
\text { madre (1999) }\end{array}$ & $\begin{array}{l}\text {-Tengo vaselina, } \\
\text { condoneh y musho, } \\
\text { musho 'ehparatrapo'. }\end{array}$ & $\begin{array}{l}\text {...I've got.... } \\
\text {..vaseline, condoms// } \\
\begin{array}{l}\text { and lots of sticking } \\
\text { plaster. }\end{array}\end{array}$ \\
\hline
\end{tabular}

Unfortunately in all these examples the standardization of the TTs results not only in the neutralization of Agrado's accent, but also in the loss of humor conveyed in the STs. In the last example the funny way Agrado says "ehparatrapo", instead of "esparadrapo", is not conveyed in the TT, and therefore the same humorous effect is not produced in the target audience.

Later on Manuela and Agrado start talking about Lola. Agrado tells Manuela that she took Lola in, as she was sick because of her drug addiction. One day Agrado comes back home to find out that Lola has disappeared, taking with her all of Agrado's belongings, even a Statue of the Virgin Mary. The description of the stolen things is amusing:

\begin{tabular}{|c|c|c|}
\hline $\begin{array}{ll}\text { FILM } & \text { AND } \\
\underline{\text { YEAR }} & \end{array}$ & SOURCE TEXT & TARGET TEXT \\
\hline $\begin{array}{l}\text { Todo sobre mi } \\
\text { madre (1999) }\end{array}$ & $\begin{array}{l}\text {-Lo que má me duele eh } \\
\text { que se llevara una tasha } \\
\text { de la Virgen del Pino que } \\
\text { mi madre me había } \\
\text { regalao... que pa qué } \\
\text { coño la querrá, si ella no } \\
\text { cree en ná. ¡A no seh que } \\
\text { ehté metida en una sehta } \\
\text { satánica y la quiera para }\end{array}$ & $\begin{array}{l}\text { What hurt most was.../ } \\
\text {... she took a statue of } \\
\text { the Virgin } \\
\text { that my mother gave } \\
\text { me./ } \\
\text { What for? } \\
\text { She doesn't believe in } \\
\text { anything./ } \\
\text { Unless she's in a }\end{array}$ \\
\hline
\end{tabular}




\begin{tabular}{|l|l|l|}
\hline & una seremonia de ésah! & $\begin{array}{l}\text { satanic sect } \\
\text { and wanted it for some } \\
\text { ritual. }\end{array}$ \\
\hline
\end{tabular}

Her over-use of the aspirated sound " $h$ ", the religious connotations, the rudeness of some of her comments, all of them make up the humor of this speech. However, there is no trace of any of this in the subtitles. Another humorous scene is when Agrado complains about the diet she has to follow because of her profession:

\begin{tabular}{|c|c|c|}
\hline $\begin{array}{ll}\text { FILM } & \text { AND } \\
\underline{\text { YEAR }} & \end{array}$ & SOURCE TEXT & TARGET TEXT \\
\hline $\begin{array}{l}\text { Todo sobre mi } \\
\text { madre (1999) }\end{array}$ & $\begin{array}{l}\text {-Uh... Dehde que te } \\
\text { fuihte no he vuerto a } \\
\text { comé como Dioh manda. } \\
\text { Bueno, también, porque, } \\
\text { claro, al seh modelo } \\
\text { tengo que cuidamme. Eh } \\
\text { lo malo de ehta } \\
\text { profesión, ique tieneh } \\
\text { que ehtá mona por } \\
\text { cohoneh! ¡Y siempre al } \\
\text { loro de los úrtimoh } \\
\text { avanseh ternológicoh en } \\
\text { sirugía y cohmética! }\end{array}$ & $\begin{array}{l}\text { Since you left, } \\
\text { I haven't had a decent } \\
\text { meal./ } \\
\text { Well, also, as a model, } \\
\text { I have to watch my } \\
\text { figure./ } \\
\text { got to look cute } \\
\text { advances in surgery } \\
\text { and cosmetics. }\end{array}$ \\
\hline
\end{tabular}

Here Agrado is showing off about her work: besides being a prostitute, she fancies herself a model. Once again, Agrado's speech is characterised by a vulgar tone ("por cojones"), colloquial speech ("mona", "estar al loro"), and religious connotations ("como Dios manda"). But these are not kept in the subtitles, which simply exhibit a synopsis of the ST, leaving aside any particularities of her speech. When Agrado goes with Manuela to see Sister Rosa in order to find a new job, she tells her that the street is getting very difficult these days: 


\begin{tabular}{|c|c|c|}
\hline $\begin{array}{ll}\text { FILM } & \text { AND } \\
\underline{\text { YEAR }}\end{array}$ & SOURCE TEXT & TARGET TEXT \\
\hline $\begin{array}{l}\text { Todo sobre mi } \\
\text { madre (1999) }\end{array}$ & $\begin{array}{l}\text {-¡Aquí la calle ehtá cada } \\
\text { día peó, hemmana! Y si } \\
\text { tuviéramoh poca } \\
\text { competensia con lah } \\
\text { putah... Lah dragh noh } \\
\text { ehtán barriendo. ¡No } \\
\text { puedo con lah dragh! Son } \\
\text { unah mamarrashah. Han } \\
\text { confundido sirco con } \\
\text { travestismo. ¡Qué digo } \\
\text { sirco!¡Mimo! }\end{array}$ & $\begin{array}{l}\text { The street is getting } \\
\text { worse } \\
\text { every day here./ } \\
\text { The whores were bad } \\
\text { enough, } \\
\text { but the drags are } \\
\text { wiping us out./ } \\
\text { I can't stand the drags. } \\
\text { They're sleazebags./ } \\
\text { They confuse } \\
\text { transvestism } \\
\text { with a circus. Worse, } \\
\text { with mime!/ }\end{array}$ \\
\hline & $\begin{array}{l}\text { Una muher eh un pelo, } \\
\text { una uña, una buena } \\
\text { bemba, pa mamahla o } \\
\text { criticah. Pero vamo a vé } \\
\text { ¿dónde se habrá vihto } \\
\text { una muher calva? ¡No } \\
\text { puedo con ellah! ¡Son } \\
\text { unah mamarrashah! }\end{array}$ & $\begin{array}{l}\text { A woman is her hair, } \\
\text { her nails,.../ } \\
\text {..lips for sucking } \\
\text { or bitching./ } \\
\text { I mean, have you ever } \\
\text { seen } \\
\text { a bald woman?/ } \\
\text { stand them. } \\
\text { They're all sleazebags! }\end{array}$ \\
\hline
\end{tabular}

One could have expected a different kind of speech from Agrado when addressing someone like Rosa, a nun. But her naturalness always breaks through: she addresses Rosa as she would anyone else. She makes use of certain phrases which are repeated, such as "no puedo...." - meaning "I can't stand", which only appears once in the TT - "son unas mamarrachas" - meaning "they are all sleazebags". "Mamarracha" is always translated like this in the films under review. These comments, together with many others, contribute to the humor of her speech. But unfortunately, the vulgarity of the ST 
is diminished in the TT: "una buena bemba para mamarla" is more offensive than "lips for sucking". When Agrado's friends complain about her inability to keep a secret, she replies:

\begin{tabular}{|c|c|c|}
\hline $\begin{array}{ll}\text { FILM } & \text { AND } \\
\text { YEAR } & \end{array}$ & SOURCE TEXT & TARGET TEXT \\
\hline $\begin{array}{l}\text { Todo sobre mi } \\
\text { madre (1999) }\end{array}$ & $\begin{array}{l}\text {-¡Yo sé mu bien cómo } \\
\text { tené la boca serrah! ¿No } \\
\text { oh he seguido la } \\
\text { corriente, como una } \\
\text { inglesa, para que Doña } \\
\text { Sumé no se cohcara de } \\
\text { ná? ¡Pero si soy un } \\
\text { modelo de dihcresión! } \\
\text { Hahta cuando me ehtoy } \\
\text { comiendo una posha sé } \\
\text { ser dihcreta. }\end{array}$ & $\begin{array}{l}\text { I know very well } \\
\text { how to keep it shut.// } \\
\text { I play along like a } \\
\text { English lady } \\
\text { so she wouldn't catch } \\
\text { on!// } \\
\text { I'm a model of } \\
\text { discretion, even } \\
\text { when I'm sucking } \\
\text { someone's cock.// }\end{array}$ \\
\hline
\end{tabular}

Agrado's use of dirty language also conveys the humor that identifies her as a character. What in other characters may sound ordinary and vulgar, in Agrado sounds funny and graceful. However, with only the subtitles to guide them, the target audience may regard Agrado as a very coarse character, and thus may not perceive how hilarious she is because of the impossibility of rendering most of those linguistic characteristics that carry humor. Thus the neutralization in the TT implies a loss of the original humor.

Agrado talks about her professional business as well as her transsexuality in a very natural way:

\begin{tabular}{|l|l|l|}
\hline$\underline{\text { FILM AND }}$ & $\underline{\text { SOURCE TEXT }}$ & $\underline{\text { TARGET TEXT }}$ \\
\hline $\begin{array}{l}\text { Yedo sobre } m i \\
\text { madre (1999) }\end{array}$ & $\begin{array}{l}\text {-Sí... de hoven fui } \\
\text { camionero (Agrado) }\end{array}$ & $\begin{array}{l}\text { I used to be a truck } \\
\text { driver. }\end{array}$ \\
\hline
\end{tabular}




\begin{tabular}{|l|l|l|}
\hline & & \multicolumn{1}{|c|}{ In Paris, } \\
\hline $\begin{array}{l}\text {-En Paríh, juhto anteh de } \\
\text { ponerme lah tetah. Luego } \\
\text { dehé er camión y me hise } \\
\text { puta (Agrado) }\end{array}$ & $\begin{array}{l}\text { Then I gave up the } \\
\text { before I got my tits.// } \\
\text { truck } \\
\text { and became a whore. }\end{array}$ \\
\hline
\end{tabular}

It is this natural style of hers that brings about the humor of these speeches. She talks about her sex change in the same spontaneous way, which undoubtedly makes the target audience laugh. In addition, Agrado's body language - she is always moving her hands when she speaks - also contributes to the humor, and that is certainly a language understood by the target audience.

Agrado has suffered a lot during her difficult life; her words are full of good advice and wisdom. She is worried about Nina's addiction and wants her to quit:

\begin{tabular}{|c|c|c|}
\hline $\begin{array}{ll}\text { FILM } & \text { AND } \\
\underline{\text { YEAR }} & \end{array}$ & SOURCE TEXT & TARGET TEXT \\
\hline $\begin{array}{l}\text { Todo sobre mi } \\
\text { madre (1999) }\end{array}$ & $\begin{array}{l}\text {-Ya sé que cuando se eh } \\
\text { joven, bueno, tampoco } \\
\text { ereh una niñata...esah } \\
\text { cosah no tienen való. } \\
\text { Pero ereh mona, } \\
\text { proporsionaita, } \\
\text { shiquitina, pero mona. } \\
\text { Hah adergasao, bueno } \\
\text { ¡con tó lo que te meteh!, } \\
\text { ¡cómo no vah a adergasá! } \\
\text { Pero bueno, lo } \\
\text { importante eh que hah } \\
\text { adergasao. }\end{array}$ & $\begin{array}{l}\text { I know that when } \\
\text { you're young... } \\
\text { Well, you're no child.// } \\
\text {...you don't value } \\
\text { these things...// } \\
\text {..but you're cute, } \\
\text { well proportioned,...// } \\
\text {...kind of small, } \\
\text { but cute.// } \\
\text { You're lost weight.// } \\
\text { Well, with all the } \\
\text { drugs...// } \\
\text { But } \\
\text { important thing is } \\
\text { you've lost } \\
\text { weight.// }\end{array}$ \\
\hline & Tieneh talento, limitaito, & You've got talent...// \\
\hline
\end{tabular}




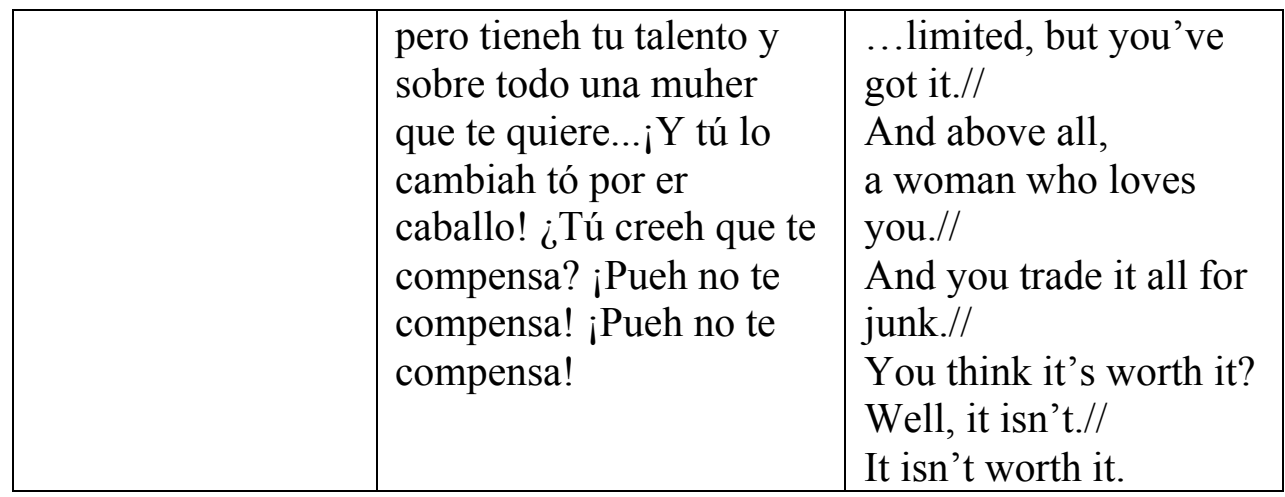

This monologue is addressed to Nina, who is listening through the door while taking drugs. Agrado's words of advice and their naturalness sound funny and tender at the same time. So much so that, the comments repeated at the end of her speech also provoke a sense of hilarity and affection in the source audience. However, their translation, even though it is a literal one, does no produce the same effect in the target audience.

Especially amusing and relevant is Agrado's monologue in the theatre, when she tells the audience "the story of her life":

\begin{tabular}{|c|c|c|}
\hline $\begin{array}{ll}\text { FILM } & \text { AND } \\
\text { YEAR } & \end{array}$ & SOURCE TEXT & TARGET TEXT \\
\hline $\begin{array}{l}\text { Todo sobre mi } \\
\text { madre (1999) }\end{array}$ & $\begin{array}{l}\text {-Me llaman La Agrado } \\
\text { porque toa mi vida sólo } \\
\text { he pretendío hasehle la } \\
\text { vida agradable a loh } \\
\text { demáh. Ademáh de } \\
\text { agradable, soy mu } \\
\text { auténtica. ¡Miren qué } \\
\text { cuerpo! ¡Tó hesho a } \\
\text { medida! }\end{array}$ & $\begin{array}{l}\text { They call me La } \\
\text { Agrado// } \\
\text {...because I've always } \\
\text { tried } \\
\text { to make people's lives } \\
\text { agreeable.// } \\
\text { As well as being } \\
\text { agreeable, } \\
\text { I'm very authentic! } \\
\text { Look at this body!// } \\
\text { All made to measure. }\end{array}$ \\
\hline & $\begin{array}{l}\text { Continúo. Tetah, doh, } \\
\text { pohque no soy ningún }\end{array}$ & $\begin{array}{l}\text { I'll continue// } \\
\text { Tits, two, }\end{array}$ \\
\hline
\end{tabular}




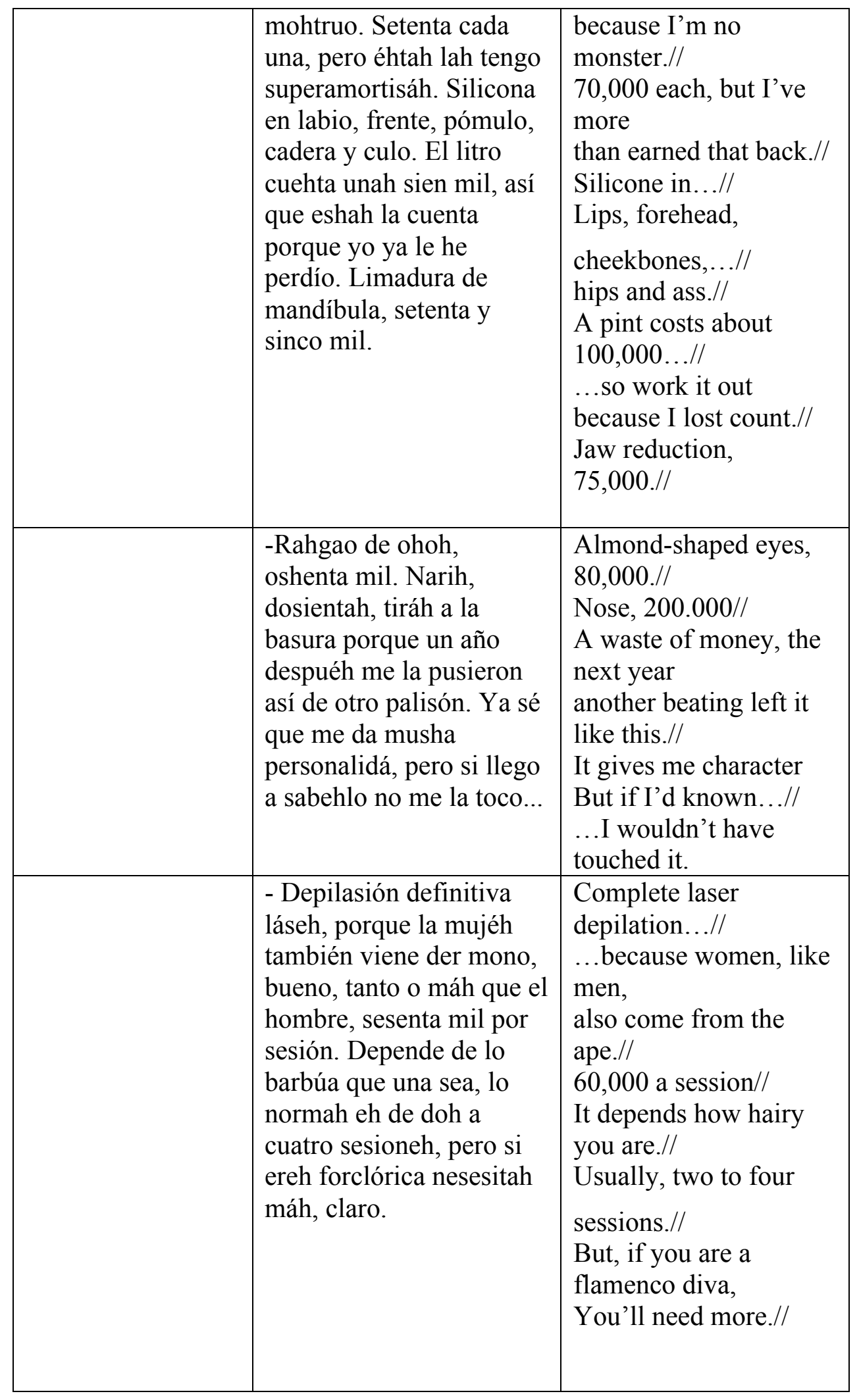




\begin{tabular}{|l|l|l|}
\hline & $\begin{array}{l}\text {-Bueno, lo que leh ehtaba } \\
\text { disiendo, ique cuehta } \\
\text { musho ser auténtica, } \\
\text { señora! Y en esah cosah } \\
\text { no } \\
\text { hay que seh rácana. } \\
\text { Pohque una es máh } \\
\text { auténtica cuando máh se } \\
\text { parese a lo que ha soñao } \\
\text { de sí mihma.... }\end{array}$ & $\begin{array}{l}\text {...it costs a lot } \\
\text { to be authentic, } \\
\text { ma'am.// } \\
\text { And one can't be stingy } \\
\text { with these things...// } \\
\ldots \text {..because you are } \\
\text { more authentic...// } \\
\ldots \text {.the more you } \\
\text { resemble } \\
\text { what you've dreamed } \\
\text { you are. }\end{array}$ \\
& \\
\hline
\end{tabular}

The exceptional hilarity of this monologue is impossible to render in the translation. Even though the translator has tried to be faithful to the original, and has respected the message of the ST, the attempt to translate the humor of the original has on the whole failed.

The humor in Almodóvar's films is intended to be transmitted to the viewer by means of linguistic and phonetic features in the SL, and through the characters' speech style. Indeed, the linguistic idiosyncrasies in the language of some of the characters are for the most part impossible to reproduce in subtitles because of the textual character of the subtitling process. It is impossible to represent the Andalusian accent of the characters in a way that could be understood and appreciated by the target audience. By the same token, the audience's own aural comprehension and inferential abilities may facilitate the appreciation of a regional accent in a subtitled film which also has the original soundtrack. When subtitling a film the problem of geographical varieties is usually solved by omitting the dialectal features. Here the translators have opted for an adequate translation of the original content, ignoring the question of accents, but consequently losing a good part of the humor of the ST. In these films the loss of regional accents has ruined the final 
text; for even though the geographical origin of the characters is not central to the storyline, it is essential to the humor of the films. If these films were to be dubbed, the problem of the regional accent could be solved by providing the character with the closest corresponding TL accent in the dubbed version, thus ensuring an appreciation of the humor.

\subsubsection{Culture Bound References}

Cultura es por naturaleza aquello que nos hace "nosotros", aquello que se "disfruta" en monopolio (por eso está adjetivada), que nos diferencia, y por lo tanto carece de parangón allende nuestra colectividad humana e idiomática. (Santoyo 1994: 142)

Culture-bound terms are "extralinguistic references to items that are tied up with a country's culture, history, or geography, and tend therefore to pose serious translation challenges" (Díaz Cintas \& Remael 2007: 200). Problems in translations arise when there is no similar term in the target culture or such term in unknown to the target viewers. This is what Rabadán has termed "vacíos referenciales" (1991: 164). In such cases, translators should then "find an alternative that will allow the viewers to fill in the target culture gap as adequately as possible" (Díaz Cintas \& Remael 2007: 201).

Whenever a culture-bound reference needs to be translated, several are the strategies devised by scholars:

- Loan

- Calque or literal translation

- Explicitation

- Substitution

- Transposition

- Lexical recreation 
- Compensation

- Omission

- Addition

All of Almodóvar's films take place in Madrid - even though the story line may develop in other cities, as is the case of Barcelona with Todo sobre mi madre:

Crecí, gocé, sufrí, engordé y me desarrollé en Madrid. Y muchas de estas cosas las realicé al mismo tiempo que la ciudad. Mi vida y mis películas están ligadas a Madrid como las dos caras de una moneda. (Almodóvar 1999: 136)

Thus constant references to Madrid can be heard throughout his films:

Madrid has figured prominently in Pedro Almodóvar's cinema $[\ldots]$. In these films, the city is regularly imaged as a cultural force, producing forms of expression and action that challenge traditional values by tearing down and rebuilding the moral institutions of Spanish life: the family, the Church, and the law. (D’Lugo 1991: 47)

In Mujeres al borde de un ataque de nervios, for example, a comment by Pepa reminds the audience where the action is taking place:

\begin{tabular}{|l|l|l|}
\hline FILM AND YEAR & SOURCE TEXT & TARGET TEXT \\
\hline $\begin{array}{l}\text { Mujeres al borde } \\
\text { de un ataque de } \\
\text { nervios (1989) }\end{array}$ & $\begin{array}{l}\text {-Llevo dos días y dos } \\
\text { noches esperándote, } \\
\text { buscándote por todo } \\
\text { Madrid y dejándote } \\
\text { recados por todas partes. }\end{array}$ & $\begin{array}{l}\text { I've spent two days } \\
\text { waiting...// } \\
\text { looking for you, } \\
\text { leaving messages. }\end{array}$ \\
\hline
\end{tabular}


But it is only the source spectator who is informed that the story is taking place in Madrid. The target audience is deprived of this information as the name of the city is not mentioned in the TT. Later on in the film Pepa appears in a TV commercial playing the role of the mother of the killer of "Cuatro Caminos", a famous borough in Madrid. It_is one of the most active and popular neighborhoods outside the center of Madrid where the stardard of living is reasonable. But here, the translator has opted to substitute "Cuatro Caminos" with its literal word in English, namely "crossroads", thus treating it as secondary information not relevant to the plot:

\begin{tabular}{|l|l|l|}
\hline FILM AND YEAR & SOURCE TEXT & TARGET TEXT \\
\hline $\begin{array}{l}\text { Mujeres al borde } \\
\text { de un ataque de } \\
\text { nervios (1989) }\end{array}$ & $\begin{array}{l}\text {-Hola. Soy la madre del } \\
\text { famoso asesino de } \\
\text { Cuatro Caminos. }\end{array}$ & $\begin{array}{l}\text { Hello. I'm the mother } \\
\text { of the } \\
\text { notorious “Crossroads } \\
\text { killer”. }\end{array}$ \\
\hline
\end{tabular}

Also Candela, Pepa's friend, makes a reference to her city Málaga, which explains her particular accent:

\begin{tabular}{|l|l|l|}
\hline FILM AND YEAR & SOURCE TEXT & TARGET TEXT \\
\hline $\begin{array}{l}\text { Mujeres al borde } \\
\text { de un ataque de } \\
\text { nervios (1989) }\end{array}$ & $\begin{array}{l}\text {-Yo no puedo ir a } \\
\text { Málaga con esta } \\
\text { papeleta. }\end{array}$ & I couldn't face my folks. \\
\hline
\end{tabular}

Yet the TT does not show any place reference, which deprives the target audience of information. While the ST indicates that Candela is not originally from Madrid, but from the south of Spain, the TT 
ignores this geographical reference that is essential for an understanding of Candela's accent as well as the ambiance of the film. Indeed, as the subtitles do not reflect her accent, the translator may have thought this geographical information irrelevant.

In La ley del deseo there is a reference to Conil - a town in Cádiz, Andalucía -, but the TT does not display that name either:

\begin{tabular}{|l|l|l|}
\hline FILM AND YEAR & SOURCE TEXT & TARGET TEXT \\
\hline $\begin{array}{l}\text { La ley del deseo } \\
\text { (1987) }\end{array}$ & $\begin{array}{l}\text {-Si me pides que me } \\
\text { quede no me voy a Conil } \\
\text { (Juan) }\end{array}$ & I'll stay if you want. \\
\hline
\end{tabular}

The Spanish spectator is provided with extra information about Juan's departure: he is leaving Madrid to go to Conil, a place on the Andalusian coast, to work as a summer waiter. But by omitting this geographical reference in the subtitles, the target audience is deprived of information that contributes to the ambience and setting of the film.

In ¿Qué he hecho yo para merecer esto?, the grandmother is constantly expressing her desire to go back to her village and leave Madrid, a city she does not like at all:

\begin{tabular}{|l|l|l|}
\hline FILM AND YEAR & SOURCE TEXT & TARGET TEXT \\
\hline $\begin{array}{l}\text { ¿Qué he hecho yo } \\
\text { para merecer esto? } \\
(1984)\end{array}$ & $\begin{array}{l}\text {-Tengo un vicio...Es lo } \\
\text { único que me gusta de } \\
\text { Madrid. }\end{array}$ & $\begin{array}{l}\text { I'm hooked, it's the } \\
\text { best thing in Madrid... }\end{array}$ \\
\hline & $\begin{array}{l}\text {-No quiero quedarme en } \\
\text { Madrid y que me } \\
\text { entierren lejos de casa } \\
\text { como a mi pobre hijo. }\end{array}$ & $\begin{array}{l}\text { I don't want to be } \\
\text { buried } \\
\text { here like my poor } \\
\text { son... }\end{array}$ \\
\hline
\end{tabular}


Whereas in the first example the translator has opted to keep the place reference, in the second example "Madrid" is replaced by "here". The translator may have taken for granted that the target spectator was already aware of the city where the film takes place. At some point there is also a reference to "la Escuela de Bellas Artes", but the TT shows neither an equivalent in the target culture, nor the original concept:

\begin{tabular}{|l|l|l|}
\hline FILM AND YEAR & SOURCE TEXT & TARGET TEXT \\
\hline $\begin{array}{l}\text { ¿Qué he hecho yo } \\
\text { para merecer esto? } \\
\text { (1984) }\end{array}$ & $\begin{array}{l}\text {-No te preocupes Miguel. } \\
\text { Te matricularé en la } \\
\text { Escuela de Bellas Artes } \\
\text { (Dentist) }\end{array}$ & $\begin{array}{l}\text { Don’t worry...// } \\
\text {...you'll have them. }\end{array}$ \\
\hline
\end{tabular}

Matador also has some allusions to Madrid and to a particular street in that city:

\begin{tabular}{|l|l|l|}
\hline FILM AND YEAR & SOURCE TEXT & TARGET TEXT \\
\hline Matador (1986) & $\begin{array}{l}\text {-Recién llegada a } \\
\text { Madrid, vi un suicidio } \\
\text { en este puente (María) }\end{array}$ & $\begin{array}{l}\text { I saw someone commit } \\
\text { suicide here. }\end{array}$ \\
\hline & $\begin{array}{l}\text {-Si es cierto lo que dice } \\
\text { Eva, hace media hora } \\
\text { que se han reunido. } \\
\text { Pueden estar ya fuera de } \\
\text { Madrid. }\end{array}$ & $\begin{array}{l}\text { If they met half an } \\
\text { hour ago...// } \\
\text {..they're far away } \\
\text { by now. }\end{array}$ \\
\hline & $\begin{array}{l}\text {-Eso es Mariano de } \\
\text { Cavia (Chief) }\end{array}$ & :.:::.:.:.: \\
\hline
\end{tabular}


None of these three examples exhibits the place references of the TT, as if the translator considered the proper names to be irrelevant for the target audience. Once again, there is a lack of information that results in a loss in the flavor of the film in the TT.

In Kika there is an allusion to La Mancha - previously mentioned - by Doña Paquita:

\begin{tabular}{|l|l|l|}
\hline FILM AND YEAR & SOURCE TEXT & TARGET TEXT \\
\hline Kika (1993) & $\begin{array}{l}\text {-Son manchegos, como } \\
\text { yo. Están muy ricos. }\end{array}$ & $\begin{array}{l}\text { It's from La Mancha, } \\
\text { like me. }\end{array}$ \\
\hline
\end{tabular}

Doña Paquita tells her interlocutor about the origin of the "choricillos" she is offering by using the adjective "manchegos". But the translator opts for the name of the region "La Mancha" as more appropriate for the target audience than the name of the inhabitants (or products) of that region.

There is also a reference to Madrid in this film:

\begin{tabular}{|l|l|l|}
\hline FILM AND YEAR & SOURCE TEXT & TARGET TEXT \\
\hline Kika (1993) & $\begin{array}{l}\text {-...cuando estés lejos de } \\
\text { Madrid (Andrea) }\end{array}$ & $\begin{array}{l}\text { when you're far from } \\
\text { here. }\end{array}$ \\
\hline
\end{tabular}

As in previous examples, "Madrid" is replaced by "here" in the TT.

In Tacones lejanos Becky uses the adjective that refers to the inhabitants of Cataluña (Catalonia), which in the TT comes out as "Barcelona", probably to facilitate the target audience's comprehension:

\begin{tabular}{|l|l|l|}
\hline FILM AND YEAR & SOURCE TEXT & TARGET TEXT \\
\hline
\end{tabular}




\begin{tabular}{|l|l|l|}
\hline $\begin{array}{l}\text { Tacones lejanos } \\
\text { (1991) }\end{array}$ & -Es catalana (Becky) & She's from Barcelona. \\
\hline
\end{tabular}

Here the TT generalizes: Becky's assistant is from Catalonia, but she does not say whether or not she comes from Barcelona. Later in the same film there is a reference to a famous clinic, the "Clínica Ruber", a cultural reference due to its popularity with the upper classes of Spanish society, as well as the name of a famous theatre in Madrid, the "María Guerrero", which takes the name of a famous $19^{\text {th }}$ century Spanish actress:

\begin{tabular}{|c|c|c|}
\hline FILM AND YEAR & SOURCE TEXT & TARGET TEXT \\
\hline $\begin{array}{l}\text { Tacones lejanos } \\
\text { (1991) }\end{array}$ & $\begin{array}{l}\text {-La actriz Becky del } \\
\text { Páramo acaba de ser } \\
\text { ingresada de urgencia en } \\
\text { la Clínica Ruber, } \\
\text { después de sufrir un } \\
\text { infarto en el escenario del } \\
\text { María Guerrero, el } \\
\text { teatro donde actuaba con } \\
\text { gran éxito (TV host) }\end{array}$ & $\begin{array}{l}\text { Becky del Páramo....// } \\
\text {....has been rushed } \\
\text { to the hospital....// } \\
\text {...after collapsing } \\
\text { on the stage...// } \\
\text {...where she was } \\
\text { enjoying } \\
\text { great success. }\end{array}$ \\
\hline
\end{tabular}

But neither the name of the clinic nor the name of the theatre appear in the TT. The name of the clinic has been substituted for by "the hospital", and there is no mention whatsoever of the name of the theatre.

In Laberinto de pasiones there are also allusions to geographical places in Spain, for example "Madrid" and "la Costa del Sol":

\begin{tabular}{|l|l|l|}
\hline FILM AND YEAR & SOURCE TEXT & TARGET TEXT \\
\hline $\begin{array}{l}\text { Laberinto de } \\
\text { pasiones }(1982)\end{array}$ & $\begin{array}{l}\text {-Sí. Fue un verano en la } \\
\text { Costa del Sol (Doctor) }\end{array}$ & Yes, one summer on \\
\hline
\end{tabular}




\begin{tabular}{|l|l|l|}
\hline & & the coast. \\
\hline & $\begin{array}{l}\text {-Yo no vivo en Madrid. } \\
\text { (Riza) }\end{array}$ & I don't live here. \\
\hline
\end{tabular}

"Madrid" is again replaced by "here", while "Costa del Sol" - which anyone familiar with the geography of Spain knows is in the south, in Andalucía - is translated as "the coast", without giving any further information to the target audience.

These examples have shown some of the losses and inconsistencies as regards geographical references in the subtitles of Almodóvar's films. There are more allusions to other cities and places in Spain, but they are reflected in Spanish in the subtitles.

In some films there are also references to famous peoplecharacters from history, folklore, culture:

\begin{tabular}{|l|l|l|}
\hline FILM AND YEAR & SOURCE TEXT & TARGET TEXT \\
\hline $\begin{array}{l}\text { Laberinto de } \\
\text { pasiones (1982) }\end{array}$ & $\begin{array}{l}\text {-¿Yo? Como no me lo } \\
\text { monte como Marujita } \\
\text { Díaz...(Guy) }\end{array}$ & $\begin{array}{l}\text { I'm the Julie Andrews } \\
\text { type. }\end{array}$ \\
\hline $\begin{array}{l}\text { Laberinto de } \\
\text { pasiones (1982) }\end{array}$ & $\begin{array}{l}\text {-Y yo Genoveva de } \\
\text { Bravante (Alicia) }\end{array}$ & $\begin{array}{l}\text { And I'm the Queen of } \\
\text { Sheba. }\end{array}$ \\
\hline $\begin{array}{l}\text { Tacones lejanos } \\
\text { (1991) }\end{array}$ & $\begin{array}{l}\text {-Su padre fue el famoso } \\
\text { Doctor Forner, } \\
\text { republicano, que se exilió } \\
\text { cuando la guerra (Becky) }\end{array}$ & $\begin{array}{l}\text { Her Dad was a famous } \\
\text { doctor } \\
\text { who left after the war. }\end{array}$ \\
\hline $\begin{array}{l}\text { Tacones lejanos } \\
\text { (1991) }\end{array}$ & $\begin{array}{l}\text {-Como en la canción de } \\
\text { Concha Piquer, "Soy lo } \\
\text { que quieras llamarme" } \\
\text { (Letal) }\end{array}$ & $\begin{array}{l}\text { Like in the old song...// } \\
\text { "..'I'm whatever you } \\
\text { call me". }\end{array}$ \\
\hline
\end{tabular}


Marujita Díaz mentioned in the first example is a well-known Spanish actress and singer who makes her living doing sexy slapstick scenes. Surprisingly the translator has decided to display "Julie Andrews", a British actress and singer who has always led a quiet life without scandals, in the subtitles. This is astonishing as Díaz and Andrews have nothing in common: probably a better equivalent for Díaz would have been Joan Collins, both women having quite similar lives in some respects.

The second example displays as a cultural equivalent for the source reference "Genoveva de Bravante" - a heroine of a popular medieval legend: "The Queen of Sheba". Clearly, for the translator both figures share the same force of personality: "Genoveva de Bravante" was a heroine, and "the Queen of Sheba" a wealthy queen who by not accepting King Solomon's proposal, showed her feminine power. In these two examples the TTs display the domestication of the cultural referents, achieving a clear and fluid style that is acceptable for the target spectator, even though the first example does not achieve such an equivalent effect in the TT. In the example from Tacones lejanos the name of the popular doctor Forner is not reflected in the subtitle; nor is the fact that he was a republican and had to leave Spain at the start of the Civil War. But the TT completely omits this important cultural reference. In the last example the translator has also opted for an omission of the cultural reference this time, by mentioning only the title of the song, not the artist. Thus these last two examples contribute to the loss of the cultural identity of the film because of their omission of cultural references.

There are numerous speeches in Almodóvar's films that contain words that carry a special relationship to Spanish culture: 


\begin{tabular}{|c|c|c|}
\hline FILM AND YEAR & SOURCE TEXT & TARGET TEXT \\
\hline $\begin{array}{l}\text { Mujeres al borde } \\
\text { de un ataque de } \\
\text { nervios (1988) }\end{array}$ & $\begin{array}{l}\text {-Es que tengo de todo: } \\
\text { música heavy, rock, soul, } \\
\text { cumbias, tengo } \\
\text { sevillanas, technopop, } \\
\text { jotas...(Taxi-driver) }\end{array}$ & $\begin{array}{l}\text { I've got everything: } \\
\text { heavy metal, rock, } \\
\text { soul... } \\
\text {...cumbias, } \\
\text { even sevillanas... } \\
\text { salsa.... } \\
\text {...techno-pop... }\end{array}$ \\
\hline
\end{tabular}

Here the TT does exhibit a cultural non-equivalent, "sevillanas", but it is significant that the word "jotas" is omitted, instead of materializing as another cultural non-equivalent, such as "sevillanas". This omission may be due to space limitations, or because it might be a type of music too alien and distant for an Anglo-Saxon culture to connect with - as opposed to sevillanas, far more popular all over the world. Nevertheless, there is another example in which the word "sevillanas" appears, and its translation does not correspond with the previous example:

\begin{tabular}{|l|l|l|}
\hline FILM AND YEAR & SOURCE TEXT & TARGET TEXT \\
\hline $\begin{array}{l}\text { La ley del deseo } \\
\text { (1987) }\end{array}$ & $\begin{array}{l}\text {-Me voy a ensayar las } \\
\text { sevillanas para la fiesta } \\
\text { de la vendimia } \\
\text { (Antonio's mother) }\end{array}$ & $\begin{array}{l}\text { I'm going to rehearse } \\
\text { dancing } \\
\text { for the grape harvest. }\end{array}$ \\
\hline
\end{tabular}

Here, the translator of La ley del deseo has used the generic word "dancing" in the subtitle, resulting in a loss of the original flavor of the film. Similarly, the word "flamenca", related to the well-known "flamenco", appears in Tacones lejanos:

\begin{tabular}{|l|l|l}
\hline FILM AND YEAR & SOURCE TEXT & TARGET TEXT \\
\hline
\end{tabular}




\begin{tabular}{|l|l|l|}
\hline $\begin{array}{l}\text { Tacones lejanos } \\
\text { (1991) }\end{array}$ & $\begin{array}{l}\text {-iQué flamenca vas a } \\
\text { estar! (Becky) }\end{array}$ & Boy, you look pretty! \\
\hline
\end{tabular}

Leaving aside any dialectal characteristic, the translator has opted for the generalization of the content by substituting "flamenca" for "pretty".

In La ley del deseo, Juan tells his boyfriend that he is leaving for the coast in order to get a summer job at a "chiringuito" - a place where one can eat and drink, usually on the beach:

\begin{tabular}{|l|l|l|}
\hline FILM AND YEAR & SOURCE TEXT & TARGET TEXT \\
\hline $\begin{array}{l}\text { La ley del deseo } \\
(1987)\end{array}$ & $\begin{array}{l}\text {-Prométeme que vendrás } \\
\text { a verme al chiringuito } \\
\text { (Juan) }\end{array}$ & $\begin{array}{l}\text { Promise you'll } \\
\text { come to see me. }\end{array}$ \\
\hline
\end{tabular}

But the target spectator is not given this information constrained in the ST, and thus is not aware of why Juan is leaving, or that he is going to work in a "chiringuito" for the summer. Thus the spectator is left to wonder, whereas the source audience is in the know.

The "Opus Dei", founded by the recently canonized José María Escribá de Balaguer, is a very prominent and powerful religious institution in Spain. It owns one of the best universities in Spain, as well as one of the best clinics. Its members are fervently religious. In Matador the character of Ángel, who has been accused of raping his neighbor Eva, has a very strict mother. Ángel's lawyer, Julia, blames her for her son's action because of the repression she exerts on him:

\begin{tabular}{|l|l|l|}
\hline FILM AND YEAR & SOURCE TEXT & TARGET TEXT \\
\hline Matador (1986) & $\begin{array}{l}\text {-Claro que con una } \\
\text { madre del Opus, no es } \\
\text { raro. }\end{array}$ & $\begin{array}{l}\text { No wonder, his } \\
\text { mother's } \\
\text { a member of Opus Dei. }\end{array}$ \\
\hline
\end{tabular}


The Opus Dei reference is kept in the TT, even in its full form, as the translator may have assumed that the target spectator would be aware of its connotations and meaning.

In ¿Qué he hecho yo para merecer esto?, two characters mention one of Madrid's most popular freeways, the M30. A Spaniard knows right away what "la M30" is, but a foreigner unfamiliar with Madrid will probably not know. That might be why the translator has opted for the "freeway" idea every time it is mentioned, as it is secondary information:

\begin{tabular}{|l|l|l|}
\hline FILM AND YEAR & SOURCE TEXT & TARGET TEXT \\
\hline $\begin{array}{l}\text { ¿Qué he hecho yo } \\
\text { para merecer esto? } \\
(1984)\end{array}$ & $\begin{array}{l}\text {-Le daré una vuelta por la } \\
\text { M30 (Antonio) }\end{array}$ & $\begin{array}{l}\text { We'll drive on the } \\
\text { freeway, }\end{array}$ \\
\hline & $\begin{array}{l}\text {-Nada, con la M30 aquí } \\
\text { pegada... (Gloria) }\end{array}$ & $\begin{array}{l}\text { Nothing. With the } \\
\text { freeway } \\
\text { right here... }\end{array}$ \\
\hline
\end{tabular}

In Kika one of the characters makes a comment about the popular Holy Week in Spain. Andrea mentions the well-known Spanish tradition of parading the different "pasos" representing the Passion of Jesus Christ:

\begin{tabular}{|l|l|l|}
\hline FILM AND YEAR & SOURCE TEXT & TARGET TEXT \\
\hline Kika (1993) & $\begin{array}{l}\text {-Mucha Virgen, mucho } \\
\text { paso de Semana Santa y } \\
\text { mucho Ángel de la } \\
\text { Guarda, pero tú no te } \\
\text { has librado, bonita } \\
\text { (Andrea) }\end{array}$ & $\begin{array}{l}\text { All these saints } \\
\text { weren't } \\
\text { much help, honey. }\end{array}$ \\
\hline
\end{tabular}


The translator has clearly included an abbreviation of all religious figures present in the original. "Virgen", "pasos de Semana Santa" and "Ángel de la Guarda" are translated as "all these saints", thus saving space while transmitting the general religious content of the ST, but losing its colloquialism. This abbreviation of the ST may be due to the multireligiosity of the target audience. A literal translation of all Catholic references may not make any sense to an audience that is not Catholic, while a general allusion to saints may indeed convey the religiosity of the original.

It seems that cultural equivalence is not considered of primary importance when translating for subtitles, and because subtitling involves evaluating the amount of information the target viewer can assimilate, a loss of information may occur. For the most part, the translators of these films regard cultural references as secondary information, and therefore as not essential to the plot. Yet, by ignoring them, they are contributing to the loss of the film's flavor and spirit. Most of Almodóvar's films lose their cultural identity in the subtitled version. In some instances there are clear domestications of scenes in which source cultural references are replaced by target culture ones. By means of this strategy the translator has chosen a fluid and natural style in the TL, but has left aside the cultural references that characterize the ST.

\subsubsection{Food References}

La gastronomía en general responde no sólo a características individualizadas de elaboración, sino con frecuencia a la utilización de materiales alimenticios que están ligados a la zona de cultura, como los garbanzos o las lentejas, nada frecuentes, por ejemplo, en Canadá. (Santoyo 1994: 142) 
Food and beverages are lexical elements deeply linked to the culture of a specific country. According to Nida (1964: 216), food and drink references entail serious difficulties for the translator "not only because the basic systems are often so different, but also because the extensions of meaning appropriate to one system rarely work in another". For Newmark (1998: 97), these elements are "the most sensitive and important expression of national culture; food terms are subject to the widest variety of translation procedures.

There are numerous references to Spanish food in Almodóvar's films, and their rendering creates problems for the translator "not only because the basic systems are often so different, but also because the extensions of meaning appropriate to one system rarely work in another" (Nida 1964: 216). From "gazpacho", "pisto", to "turrón", all these types of food that are part of the gastronomy of Spain, produce problems in the translation process, because of the difficulty of finding equivalents in the TL.

In Laberinto de pasiones two typical Spanish dishes appear in the dialogues, "fabada" and "empanada gallega":

\begin{tabular}{|l|l|l|}
\hline FILM AND YEAR & SOURCE TEXT & TARGET TEXT \\
\hline $\begin{array}{l}\text { Laberinto de } \\
\text { pasiones (1982) }\end{array}$ & $\begin{array}{l}\text {-Entonces fulanita te } \\
\text { llama y tal para charlar } \\
\text { contigo y para invitarte a } \\
\text { un cutre bar a comeros } \\
\text { una ensalada de algo. En } \\
\text { fin, bueno, una } \\
\text { empanada gallega mejor } \\
\text { casi (Almodóvar) }\end{array}$ & $\begin{array}{l}\text { So-and-so has a chat } \\
\text { with you,// } \\
\text { and invites you to a } \\
\text { cheap café// } \\
\text { for a salad or } \\
\text { something.// } \\
\text { Better, a Cornish } \\
\text { pastry. }\end{array}$ \\
\hline & -¡Una fabada! (Fabio) & Tripe and onions! \\
\hline
\end{tabular}


In the first example, the translator has chosen to give an approximate equivalent for "empanada gallega" in the target culture with "Cornish pastry". Nevertheless, these two dishes have nothing in common: as the "empanada gallega" is sour, and the "Cornish pastry" is sweet. I wonder if the target spectator knows that Cornish pastry is British in origin. In the second example, the translation does not succeed despite the mention of the main ingredients of the source meal.

In La ley del deseo examples of different foods used in comic blessings before a meal:

\begin{tabular}{|l|l|l|}
\hline FILM AND YEAR & SOURCE TEXT & TARGET TEXT \\
\hline $\begin{array}{l}\text { La ley del deseo } \\
\text { (1987) }\end{array}$ & $\begin{array}{l}\text {-Bendice señor la sopa } \\
\text { de fideos... }\end{array}$ & $\begin{array}{l}\text { Oh, Lord, bless the } \\
\text { chicken soup... }\end{array}$ \\
\hline & -El lenguado meunier... & The sole meunière... \\
\hline & $\begin{array}{l}\text {-Y el flan que vamos a } \\
\text { tomar de vuestra } \\
\text { liberalísima mano por } \\
\text { Cristo nuestro señor... }\end{array}$ & $\begin{array}{l}\text { and the custard which } \\
\text { we are about to partake. }\end{array}$ \\
\hline
\end{tabular}

In the first and third examples, "sopa de fideos" and "flan" are substituted for their closest equivalents in the target culture: "chicken soup" and "custard", whereas "lenguado meunière" is translated directly in the TT.

¿Qué he hecho yo para merecer esto? exhibits several dialogues in which some common pastry and dishes appear:

\begin{tabular}{|l|l|l|}
\hline FILM AND YEAR & SOURCE TEXT & TARGET TEXT \\
\hline $\begin{array}{l}\text { ¿Qué he hecho yo } \\
\text { para merecer esto? } \\
\text { (1984) }\end{array}$ & $\begin{array}{l}\text {-¿Quieres una } \\
\text { magdalena? } \\
\text { (Grandmother) }\end{array}$ & Want a cup cake? \\
\hline
\end{tabular}




\begin{tabular}{|l|l|l|}
\hline & $\begin{array}{l}\text {-Qué va abuela, no me } \\
\text { hacen las magdalenas } \\
\text { (Toni) }\end{array}$ & I'm not into cakes. \\
\hline & $\begin{array}{l}\text {-Pídele un bollo a la } \\
\text { abuela, a ver si se apiada } \\
\text { de ti (Gloria) }\end{array}$ & $\begin{array}{l}\text { Ask grandma for a } \\
\text { cake... }\end{array}$ \\
\hline
\end{tabular}

The grandma in the film keeps "magdalenas" and "bollos", two pastry specialties, locked in her room. These two types of very common Spanish pastries are simply translated as "cakes", which is the most appropriate target equivalent.

\begin{tabular}{|l|l|l|}
\hline FILM AND YEAR & SOURCE TEXT & TARGET TEXT \\
\hline $\begin{array}{l}\text { ¿Qué he hecho yo } \\
\text { para merecer esto? } \\
\text { (1984) }\end{array}$ & $\begin{array}{l}\text {-Juani ¿me dejas un poco } \\
\text { de laurel que estoy } \\
\text { haciendo un caldo? } \\
\text { (Gloria) }\end{array}$ & $\begin{array}{l}\text { Can you lend me a } \\
\text { bay leaf or two? }\end{array}$ \\
\hline & $\begin{array}{l}\text {-Pues este caldo no huele } \\
\text { nada mal (Policeman 1) }\end{array}$ & It smells lovely. \\
\hline & $\begin{array}{l}\text {-¿Quiere una taza de } \\
\text { caldo? (Gloria) }\end{array}$ & Want a little soup? \\
\hline
\end{tabular}

On the other hand, the word "caldo" (a Spanish soup) creates different options for the translator every time it appears in the film. In the first instance, the translator opts for a complete omission of the "caldo" reference in the TT; in the second instance it is replaced by "it". Not until the last example does the audience become aware that Gloria is cooking "soup". Indeed, the translator has decided to omit the food reference until Gloria offers it to the policemen. 
In Matador "morcillas", "chorizos" and "pipas" appear in some of the dialogues:

\begin{tabular}{|l|l|l|}
\hline FILM AND YEAR & SOURCE TEXT & TARGET TEXT \\
\hline Matador (1986) & $\begin{array}{l}-¿ \text { Me das una ristra de } \\
\text { morcis que a mi madre la } \\
\text { privan? }\end{array}$ & $\begin{array}{l}\text { Can I take some } \\
\text { sausages? } \\
\text { Mom loves them. }\end{array}$ \\
\hline & $\begin{array}{l}\text {-Si quieres te doy una } \\
\text { ristra de morcillas } \\
\text { (Diego) }\end{array}$ & $\begin{array}{l}\text { I can give you some } \\
\text { sausages. }\end{array}$ \\
\hline & $\begin{array}{l}-¿ \text { Y los chorizos y las } \\
\text { morcillas? (Policeman 2) }\end{array}$ & $\begin{array}{l}\text { What about the } \\
\text { sausages? }\end{array}$ \\
\hline & $-¿$ Quieres pipas? (Pilar) & Want some? \\
\hline
\end{tabular}

In the examples containing "morcillas", one sees that the translator has chosen "sausages". In the third example both "chorizos" and "morcillas" are translated as "sausages". The non existent equivalents for these two Spanish products may have determined the translator's choice of the same word for both. In the last example, there is an omission of the word "pipas" (sunflower seeds) in the TT, probably because this product is not consumed by people in the target culture, whereas it is very popular in Spain.

Mujeres has several examples in which "gazpacho" - a refreshing summer soup made with vegetables and served chilled - appears:

\begin{tabular}{|l|l|l|}
\hline FILM AND YEAR & SOURCE TEXT & TARGET TEXT \\
\hline $\begin{array}{l}\text { Mujeres al borde } \\
\text { de un ataque de } \\
\text { nervios } \text { (1988) }\end{array}$ & $\begin{array}{l}\text {-El gazpacho estaba } \\
\text { dopado con somníferos } \\
\text { (Pepa) }\end{array}$ & $\begin{array}{l}\text { It was spiked with } \\
\text { barbiturates. }\end{array}$ \\
\hline
\end{tabular}




\begin{tabular}{|l|l|l|}
\hline & $\begin{array}{l}\text {-Mira cómo voy yo, } \\
\text { bañada de gazpacho, } \\
\text { medio ciega y descalza } \\
\text { (Pepa) }\end{array}$ & $\begin{array}{l}\text { Look what she did to } \\
\text { me! }\end{array}$ \\
\hline & $\begin{array}{l}\text {-Jefe, a este gazpacho le } \\
\text { han echado algo } \\
\text { (Policeman 2) }\end{array}$ & $\begin{array}{l}\text { Chief, this stuff } \\
\text { has been spiked. }\end{array}$ \\
\hline
\end{tabular}

The word "gazpacho" is not kept in the subtitles, it is omitted every time it appears. Probably the reason for its omission is that it is a Spanish specialty that not everyone in the target audience is acquainted with.

Both "turrón", a Christmas delicacy in Spain, and "pisto" are found in Atame:

\begin{tabular}{|l|l|l|}
\hline FILM AND YEAR & SOURCE TEXT & TARGET TEXT \\
\hline Átame (1990) & $\begin{array}{l}-¿ \text { Cuánto es el turrón? } \\
\text { (Boy) }\end{array}$ & How much is that? \\
\hline & $\begin{array}{l}-¿ \text { Que hay? Pues pisto } \\
\text { (Doña Paquita) }\end{array}$ & It's “pisto". \\
\hline
\end{tabular}

Whereas in the first example the translator opts to omit "turrón" in the TT, by displaying the demonstrative "that", the second example exhibits a cultural non-equivalent by using the Spanish word, and thus enriching the TT.

In Tacones lejanos there is just one example of a dialogue containing a food reference. But it was worth mentioning:

\begin{tabular}{|l|l|l|}
\hline FILM AND YEAR & SOURCE TEXT & TARGET TEXT \\
\hline Tacones lejanos & -Perdone que no le haya & I forgot to send you \\
\hline
\end{tabular}




\begin{tabular}{|l|l|l|}
\hline (1991) & $\begin{array}{l}\text { mandado algún jamón } \\
\text { (Rebeca) }\end{array}$ & a thank you note! \\
\hline
\end{tabular}

This example, apart from presenting a food reference, has deep cultural connotations in the SL. In Spain there is no culture of "card notes", as in Anglo-Saxon countries. In Spain when someone is thanked for having done a big favor, for someone else, the usual way to show appreciation is to give that person a "jamón" (ham). This is why Rebeca ironically tells the judge she is sorry for "not sending him a ham". What makes sense in the original culture may not make sense in the target one, which might be why the translator has opted for the cultural equivalent in the target culture of "a thank you note". Thus the subtitler has given an acceptable translation instead of an adequate one (a ham), as it may cause problems for the target audience who may not understand the meaning of giving someone a ham.

The word "chorizo", "choricillo" more precisely, appears in Kika - it was also commented on in section 3.2.3. about rural life -:

\begin{tabular}{|l|l|l|}
\hline FILM AND YEAR & SOURCE TEXT & TARGET TEXT \\
\hline Kika (1993) & $\begin{array}{l}\text {-Cómase un choricillo } \\
\text { (Doña Paquita) }\end{array}$ & Have some chorizo. \\
\hline
\end{tabular}

Here the diminutive of "chorizo", which is "choricillo", is not kept in the TT, even though the translator has opted for the inclusion of a cultural non-equivalent, considering perhaps the familiarity of the target audience with the product, or simply because its presence in the film is irrelevant.

Todo sobre mi madre, also exhibits a food reference, in this case by Huma: 


\begin{tabular}{|l|l|l|}
\hline FILM AND YEAR & SOURCE TEXT & TARGET TEXT \\
\hline $\begin{array}{l}\text { Todo sobre } m i \\
\text { madre (1999) }\end{array}$ & $\begin{array}{l}\text {-Para mi solo una } \\
\text { esqueixada de Cal } \\
\text { Pinxo. }\end{array}$ & $\begin{array}{l}\text { I'll just have an } \\
\text { "esqueixada". }\end{array}$ \\
\hline
\end{tabular}

Once again the TT displays a cultural non-equivalent, as it is secondary information. And yet the translation problem could have been solved by means of the word "salad", since an "exqueixada" is a summer salad from Catalonia.

Most of the instances analyzed in this section exhibit target equivalents for the source food reference. Translators seem to resort to this strategy when the food reference has a close equivalent in the TL, even though both references may not be really similar. At other times, the complexity of translating food references seems to compel the subtitlers of Almodóvar's films to use cultural non-equivalents in the subtitles. The impossibility of finding an equivalent in the TL, and its irrelevance to the action of the film, may have encouraged translators to introduce the source reference in the TT. When these source references are kept, they serve to enrich the target culture and to respect the cultural identity of the film. Besides, the presence of the visual item supports the ST reference, which may also encourage the translators to include the source reference as such. Therefore, the presence of these references in the TTs contributes to the ambiance of the subtitled version without threatening the source information.

\subsubsection{Vocabulary Related to Drugs}

The cruel reality of drug-addiction in Spanish society is clearly reflected by characters who are addicted to different drugs, and whose 
speech shows vocabulary connected to the world of drugs. Instead of avoiding the problem of drugs, Almodóvar represents it with naturalness. In Spain drugs started to be a problem in the $80 \mathrm{~s}$, so the director introduces drug addicts in his cinema, but always as something natural, never as a dramatic fact.

"Caballo" appears in several instances, and it is usually translated as "smack" or "junk", the former being the equivalent for the source word, and the latter meaning "rubbish":

\begin{tabular}{|l|l|l|}
\hline FILM AND YEAR & SOURCE TEXT & TARGET TEXT \\
\hline $\begin{array}{l}\text { Todo sobre } m i \\
\text { madre (1999) }\end{array}$ & $\begin{array}{l}\text {-No lo comentes, pero } \\
\text { Nina tiene problemas con } \\
\text { el caballo (Huma) }\end{array}$ & $\begin{array}{l}\text { Don’t tell anyone, but } \\
\text { Nina's } \\
\text { got problems with } \\
\text { junk. }\end{array}$ \\
\hline $\begin{array}{l}\text { Todo sobre mi } \\
\text { madre (1999) }\end{array}$ & $\begin{array}{l}\text {-Ella está enganchada al } \\
\text { caballo,...(Huma) }\end{array}$ & She's hooked on junk, \\
\hline $\begin{array}{l}\text { Atame (1990) } \\
\text {-Antes de la película } \\
\text { tomaba caballo (Marina) }\end{array}$ & $\begin{array}{l}\text { I was hooked on } \\
\text { smack. }\end{array}$ \\
\hline $\begin{array}{l}\text { Átame (1990) } \\
\text { ¿Qué he hecho yo } \\
\text { para merecer esto? } \\
\text { (1984) }\end{array}$ & $\begin{array}{l}\text {-¿No habrás tomado } \\
\text { caballo? (Cristal) }\end{array}$ & $\begin{array}{l}\text {-..Been } \\
\text { sniffing some smack? }\end{array}$ \\
\hline
\end{tabular}

The choice seems to be a matter of the translator's personal preference: the translation of "caballo" in Todo sobre mi madre is "junk", which diminishes the meaning of the original word. Its equivalent "smack" is used in Átame and in ¿Qué he hecho yo para merecer esto?. The words "coca" (cocaine) or "raya" (a line, fix, dose) also appear in the ST: 


\begin{tabular}{|l|l|l|}
\hline $\begin{array}{l}\text { Carne trémula } \\
\text { (1997) }\end{array}$ & $-¿$ Coca? (David) & Coke? \\
\hline $\begin{array}{l}\text { La ley del deseo } \\
\text { (1987) }\end{array}$ & $\begin{array}{l}\text {-...o si has dejado ya la } \\
\text { coca (Juan) }\end{array}$ & ...or given up snow? \\
\hline $\begin{array}{l}\text { La ley del deseo } \\
\text { (1987) }\end{array}$ & -¡Más raya! (Tina) & More coke! \\
\hline
\end{tabular}

"Coke" is the most common translation for "coca" or "raya". But in one example "snow" is another equivalent for "coke". Similarly, "chino" (a dose) is translated by its equivalent "fix" on both occasions:

\begin{tabular}{|l|l|l|}
\hline FILM AND YEAR & SOURCE TEXT & TARGET TEXT \\
\hline $\begin{array}{l}\text { Todo sobre } m i \\
\text { madre }(1999)\end{array}$ & $\begin{array}{l}-¡ \text { A ti te ha sentado fatal } \\
\text { ese chino! (Agrado) }\end{array}$ & $\begin{array}{l}\text { That fix didn’t agree } \\
\text { with you. }\end{array}$ \\
\hline $\begin{array}{l}\text { Carne trémula } \\
(1997)\end{array}$ & $\begin{array}{l}\text { - } \text { (Un chino, por Dios! } \\
\text { (Elena) }\end{array}$ & Oh, God, I need a fix. \\
\hline
\end{tabular}

There are also isolated examples that deal with different types of drugs, and exhibit their direct equivalents in the translations:

\begin{tabular}{|l|l|l|}
\hline FILM AND YEAR & SOURCE TEXT & TARGET TEXT \\
\hline $\begin{array}{l}\text { Todo sobre } m i \\
\text { madre (1999) }\end{array}$ & $\begin{array}{l}\text {-También tengo bolso, } \\
\text { éxtasis, } \\
\text { farlopa...(Junkie) }\end{array}$ & $\begin{array}{l}\text { Yeah, I got a purse...// } \\
\text {...ecstasy, toot,... }\end{array}$ \\
\hline Átame (1990) & -¿Queréis porro? (Berta) & $\begin{array}{l}\text { Would you like a } \\
\text { joint? }\end{array}$ \\
\hline
\end{tabular}




\begin{tabular}{|l|l|l|}
\hline Átame (1990) & $\begin{array}{l}\text {-No, pero si quieres } \\
\text { choco o burro (Drug- } \\
\text { dealer) }\end{array}$ & $\begin{array}{l}\text { No, I got hash and } \\
\text { scag. }\end{array}$ \\
\hline
\end{tabular}

We see that the colloquialism of the terms relating to the world of drugs is kept in the subtitles, which show the closest equivalents for the source terms. Translators have not omitted any reference to drugs, and have chosen existing equivalents in English in order to preserve the content and ambiance of the ST. Thus the characters' way of life is perfectly transmitted through the subtitles.

\subsubsection{Wordplay and Sayings}

Wordplay is the general name for the various textual phenomena in which structural features of the language(s) used are exploited in order to bring about a communicatively significant confrontation of two (or more) linguistic structures with more or less similar forms and more or less different meanings. (Delabastita 1996: 128)

Translating wordplays turns out to be one of the most difficult tasks for any translator. Delabastita (1996: 127) reflects upon the idea of the translatability of wordplay, but other scholars and $\underline{\text { translators simply advocate its untranslatability. Some prefer to omit }}$ the wordplay in the TT, whereas others opt for an explanatory footnote. There are even translators who opt for the introduction of wordplay in the TT when there is none in the ST. Nevertheless, the translator who wants to be faithful to the ST, and keep the wordplay where it really appears, will have to be unfaithful: 
The only way to be faithful to the original text (i.e. to its verbal playfulness) is paradoxically to be unfaithful to it (i.e. to its vocabulary and grammar). (Delabastita 1996: 135).

It could be said that translating sayings is not as difficult as translating wordplay because of the possible equivalents in many languages. However, when analyzing sayings one can see that it is not always easy:

\begin{tabular}{|l|l|l|}
\hline $\begin{array}{l}\text { FILM AND } \\
\text { YEAR }\end{array}$ & SOURCE TEXT & TARGET TEXT \\
\hline $\begin{array}{l}\text { ¿Qué he hecho yo } \\
\text { para merecer esto? } \\
\text { (1984) }\end{array}$ & $\begin{array}{l}\text {-En mi pueblo dicen que } \\
\text { "el que no ha visto } \\
\text { Graná no ha visto ná" } \\
\text { (Grandma) }\end{array}$ & $\begin{array}{l}\text { If you haven't seen } \\
\text { Granada } \\
\text { you haven't seen } \\
\text { nothing. }\end{array}$ \\
\hline $\begin{array}{l}\text { Tacones lejanos } \\
\text { (1991) }\end{array}$ & $\begin{array}{l}\text {-Culo veo, culo quiero } \\
\text { (Alberto) }\end{array}$ & $\begin{array}{l}\text { She sees it, she wants } \\
\text { it. }\end{array}$ \\
\hline $\begin{array}{l}\text { Laberinto de } \\
\text { pasiones (1982) }\end{array}$ & $\begin{array}{l}\text {-Más vale que sobre que } \\
\text { no que falte (Fabio) }\end{array}$ & $\begin{array}{l}\text { Better too much than } \\
\text { too little. }\end{array}$ \\
\hline $\begin{array}{l}\text { Laberinto de } \\
\text { pasiones (1982) }\end{array}$ & $\begin{array}{l}\text {-Burro grande ande o } \\
\text { no ande (Fabio) }\end{array}$ & $\begin{array}{l}\text { Quantity not quality } \\
\text { is what it counts. }\end{array}$ \\
\hline
\end{tabular}

In the first example the saying is deeply rooted in the Spanish culture. It contains ellipses of the word "Granada" as "Graná", and "nada" as "ná", which represent an imitation of the Andalusian accent. Needless to say, because of subtitling limitations these features cannot be represented in the translation. The character also mentions her village at the beginning of her speech which is omitted 
in the TT, thereby undermining the strong feeling the character has towards her village, present throughout the film. What the TT displays is merely a literal translation of the source saying that does not convey the equivalent effect of the character's register. Similarly, the hilarity of the second saying is lost in the TT, as it only displays the content of the original without any of its spirit. The meaning of the third saying is conveyed in the TT, but it is flavourless. In addition, the fourth saving is also lost in the translation which merely displays the content.

There is a comment in ¿Qué he hecho yo para merecer esto? where wordplay is present. The wordplay is uttered by the grandmother who plays her own game by changing the colloquial word "verdularia" into "perdularia" (from "perder"- to lose):

\begin{tabular}{|l|l|l|}
\hline $\begin{array}{l}\text { FILM AND } \\
\text { YEAR }\end{array}$ & SOURCE TEXT & TARGET TEXT \\
\hline $\begin{array}{l}\text { ¿Qué he hecho yo } \\
\text { para merecer esto? } \\
\text { (1984) }\end{array}$ & $\begin{array}{l}\text {-¡Perdularia, que eres } \\
\text { una perdularia! ¡Lo } \\
\text { pierdes todo! (Grandma) }\end{array}$ & Scatter brain, always \\
losing things... \\
\hline
\end{tabular}

The translation of this wordplay is clearly not kept in the TT due to the difficulty involved. Instead, the translation displays an equivalent for the meaning of the original wordplay, but without its hilarity.

In Matador Ángel's mother tells her son off:

\begin{tabular}{|l|l|l|}
\hline FILM AND & SOURCE TEXT & TARGET TEXT \\
$\underline{\text { YEAR }}$ & & \\
\hline
\end{tabular}




\begin{tabular}{|l|l|l|}
\hline Matador (1986) & $\begin{array}{l}\text {-La tormenta...jTú sí } \\
\text { que me atormentas! } \\
\text { (Angel's mother) }\end{array}$ & $\begin{array}{l}\text { The storm! You } \\
\text { certainly } \\
\text { are stormy! }\end{array}$ \\
\hline
\end{tabular}

Here the wordplay is kept by means of the words "storm" and "stormy". There is a linguistic transposition of the verb "atormentar" to the adjective "stormy", as well as a change in the character to which this wordplay refers. In this particular exchange the translator has been able to render an equivalent wordplay of the source one.

Kika also presents some of this wordplay, and in this case it has a vulgar content:

\begin{tabular}{|c|c|c|}
\hline $\begin{array}{l}\text { FILM } \\
\text { YEAR }\end{array}$ & SOURCE TEXT & TARGET TEXT \\
\hline Kika (1993) & $\begin{array}{l}\text {-...nombre artístico, Paul } \\
\text { Bazzo (Andrea) }\end{array}$ & $\begin{array}{l}\text { stage name Paul } \\
\text { Bazzo. }\end{array}$ \\
\hline & $\begin{array}{l}\text {-¿Recuerdan } \\
\text { “Raboterapia"? } \\
\text { (Andrea) }\end{array}$ & $\begin{array}{l}\text { Remember } \\
\text { "Dickotherapy"? }\end{array}$ \\
\hline & $\begin{array}{l}\text {-...y "Haz el amor y no } \\
\text { la guarra"? (Andrea) }\end{array}$ & $\begin{array}{l}\text {...and "Spill the } \\
\text { sperm"? }\end{array}$ \\
\hline
\end{tabular}

The pun in the first example has been translated literally, which can make no sense to the target audience. It is a question of homophony, since the name and last name "Paul Bazzo" pronounced together is a homophone of "polvazo" ("a screw, a shag"), which is impossible to render in the translation. However, the second example does communicate the source pun by means of a suitable equivalent in English, preserving the pun and the rudeness of the original. The third example displays an approximate pun: the content is not the 
same, as it would be impossible to find an equivalent in the TL. But the vulgarity is kept.

In Laberinto de pasiones and in Todo sobre mi madre there are two characters whose names have a special meaning in the SL. In Laberinto de pasiones one finds the name "Patty Diphusa", a pun that in English means "astounded". Nevertheless, the TT shows no change or adaptation in the TL; nor does it convey the same sense as the ST. Similarly in Todo sobre mi madre the character of Huma explains the reason that made her choose this stage name:

\begin{tabular}{|c|c|c|}
\hline $\begin{array}{ll}\text { FILM } & \text { AND } \\
\underline{\text { YEAR }}\end{array}$ & SOURCE TEXT & TARGET TEXT \\
\hline $\begin{array}{l}\text { Todo sobre mi } \\
\text { madre (1999) }\end{array}$ & $\begin{array}{l}\text {-Empecé a fumar por } \\
\text { culpa de Bette Davis. Por } \\
\text { imitarla. A los dieciocho } \\
\text { ya fumaba como un } \\
\text { carretero. Por eso me } \\
\text { puse Huma. Humo es lo } \\
\text { único que ha habido en } \\
\text { mi vida (Huma) }\end{array}$ & $\begin{array}{l}\text { I started smoking } \\
\text { because of Bette } \\
\text { Davis.// } \\
\text { To imitate her.// } \\
\text { At } 18 \text {, I was smoking } \\
\text { like a chimney.// } \\
\text { That's why } \\
\text { I called myself } \\
\text { Huma.// } \\
\text { Smoke is all there's } \\
\text { been } \\
\text { in my life. }\end{array}$ \\
\hline
\end{tabular}

The explanation is perfectly clear for the Spanish audience; yet, the foreign spectator probably won't understand it, not knowing that in Spanish "Huma" comes from "humo" (smoke). The TT seems to be unsuited for the transmission of the ST, since "Huma" has nothing in common with "smoke". The pun is therefore lost in the translation.

At the very beginning of Laberinto de pasiones, the spectator sees a crazy Fabio trying to flirt with an unknown man. In order to "break the ice", Fabio sends him a note in which the spectator reads: 


\begin{tabular}{|l|l|l|}
\hline $\begin{array}{l}\text { FILM AND } \\
\text { YEAR }\end{array}$ & SOURCE TEXT & TARGET TEXT \\
\hline $\begin{array}{l}\text { Laberinto de } \\
\text { pasiones (1982) }\end{array}$ & $\begin{array}{l}\text {-Sí, me gustaría hacerte } \\
\text { phelix (Taylor) exta } \\
\text { tarde. }\end{array}$ & $\begin{array}{l}\text { I would really like to } \\
\text { make } \\
\text { you happy this } \\
\text { afternoon. }\end{array}$ \\
\hline
\end{tabular}

The pun with "phelix (Taylor)" (Liz Taylor) in the ST is not kept in the TT because of the difficulty in finding a suitable equivalent to convey the same meaning. Instead, the translator opts to transmit the content by leaving out any hint of the original wordplay.

Most puns in these films are rendered literally, which makes it impossible for the target spectator to understand what is going on. The target viewer may sometimes feel lost or confused, not to mention deprived of any humor conveyed through the puns. While the translator sometimes chooses to transmit the content of the original one, thus, every trace of the original is lost. Thus the main focus of the translators is the achievement of acceptability to the detriment of adequacy in the TT. Sometimes the translation also displays a pun, even though it may differ from the source one, due mainly to cultural differences. Most of the humor in these puns is not transmitted through the TTs, thereby producing a different effect on the target audience, which cannot appreciate the hilarity of the original. 
It is worth mentioning that there were errors in the subtitles of Almodóvar's films. There is a scene in ¿Qué he hecho yo para merecer esto? in which the synchronicity of the subtitles with the characters' speeches fails:

When there is more than one person speaking at the same time the spotter has to make the difficult decision of deciding which information will make it to the target language and which will have to be deleted. In addition, the timing will have to be done in as clear a way as possible so as not to confuse the viewer, who can hear several voices at the same time and may not know who is saying what. In these cases, good layout of the subtitles is also essential. (Díaz Cintas \& Remael 2007: 91)

It is the scene when Gloria, the protagonist, is in her bedroom asking her husband for money as she does not have enough to buy food. The spectator who knows both Spanish and English can perceive that every time the characters speak, the subtitle that appears on the screen is not the right one. Every intervention by Gloria shows the wrong subtitle, and the same happens with her husband's words. It is strange to find such a blatant error, and one wonders whether these films are revised once the subtitles are inserted.

Apart from this error of synchronization, there are other examples in which the subtitles, far from expressing an inappropriate translation, exhibit a wrong one. These errors have to do with grammar and vocabulary, and are due either to the translator's ignorance, or to a possible lapse. The following example shows a misunderstanding of the ST on the part of the translator: 


\begin{tabular}{|l|l|l|}
\hline$\underline{\text { FILM }}$ YEAR & SOURCE TEXT & TARGET TEXT \\
\hline $\begin{array}{l}\text { Laberinto de } \\
\text { pasiones (1982) }\end{array}$ & $\begin{array}{l}\text {-Y tienes más morro } \\
\text { que una zorra. Como no } \\
\text { te calles te voy a romper } \\
\text { la lamparería (Angustias) }\end{array}$ & $\begin{array}{l}\text { If you don't shut it, I'll } \\
\text { bust up your shop...// } \\
\text { And your mouth. }\end{array}$ \\
\hline
\end{tabular}

In the ST the character Angustias threatens a shop assistant with busting up her shop; she does not say anything about the shop assistant's mouth. But what she says at the beginning, "tienes más morro que una zorra" ("to have a nerve" in a vulgar way), may have been misunderstood by the translator as "morro" is the right word to refer to the mouth of some animals. The literal meaning of the expression would make no sense in the TT.

Three errors can be found in Matador that are all related to the word "excitado/a". "Estar excitado/a" means "to be horny/turned on"; however, in the examples where this expression appears the translator has mistakenly used the word "excited" which in Spanish means "entusiasmado". Thus the sexual connotations of the ST have been lost:

\begin{tabular}{|l|l|l|}
\hline $\begin{array}{l}\text { FILM } \\
\text { YEAR }\end{array}$ & SOURCE TEXT & TARGET TEXT \\
\hline Matador (1986) & $\begin{array}{l}\text {-Él estaba muy } \\
\text { excitado...(Ángel) }\end{array}$ & He was very excited... \\
\hline & $\begin{array}{l}\text {-...y me había excitado } \\
\text { (Ángel) }\end{array}$ & ...I was very excited. \\
\hline & $\begin{array}{l}\text {-Perdona, es que estoy } \\
\text { tan excitada que no sé lo } \\
\text { que digo (María) }\end{array}$ & $\begin{array}{l}\text { I'm so excited I'm } \\
\text { losing my mind. }\end{array}$ \\
\hline
\end{tabular}


Somebody with a good knowledge of English easily notices such mistakes, and one wonders how the translator could not know the right word for "excitado" in English.

There is an utterance in Mujeres which is wrongly translated as well. In this scene Pepa is informing Lucía that Carlos' girlfriend had better do something, or she will lose her boyfriend:

\begin{tabular}{|l|l|l|}
\hline $\begin{array}{l}\text { FILM AND } \\
\text { YEAR }\end{array}$ & SOURCE TEXT & TARGET TEXT \\
\hline $\begin{array}{l}\text { Mujeres al borde } \\
\text { de un ataque de } \\
\text { nervios (1988) }\end{array}$ & $\begin{array}{l}\text {-Tendrá que espabilarse } \\
\text { (Pepa) }\end{array}$ & She'd better wake up. \\
\hline
\end{tabular}

The exact meaning of the verb "espabilarse" in the above example is "buck up", not "wake up" as the TT shows. The reason for this misunderstanding may be that the character who should "buck up" is sleeping during the scene.

To sum up, the errors of synchronization which appear in some of Almodóvar's films show a lack of revision of the final subtitled version. On the other hand, errors in grammar and vocabulary are definite evidence of a lack of proficiency in either Spanish or English (or both) on the part of the translator. They may also be due to negligence on the part of the translator. 


\title{
3.3. Summary of Methods and Conclusions
}

\author{
Esteban: ¡Qué manía de \\ cambiar el título! ;All about Eve \\ significa "Todo sobre Eva"! \\ Manuela: Todo sobre Eva suena \\ raro. (Todo sobre mi madre)
}

Almodóvar's films are original in style and content. They show Spanish society as it really is by illustrating its virtues and defects, and by presenting characters from the disadvantaged classes. The language of these characters, which is full of colloquialisms, slang, dirty words, accent particularities and colorful expressions, represents serious difficulties for the audiovisual translator.

The dirty and vulgar language that defines most of the characters in these films is difficult to reproduce in the translation because of the marked differences that exist between Spanish and English: they share basic meanings, but differ in the use of resources to express these meanings, as well as in the frequency of use of such resources (Rabadán 2002b: 39). And yet these differences are being 
overcome by the audiovisual translators, as most dirty and vulgar expressions are successfully translated.

In the subtitled versions of these films, the translations of insulting and scatological expressions are reasonably successful, despite certain incongruities. Most subtitles display the closest natural equivalents of the source expressions: whenever there is a close equivalent for a vulgar term, translators decide to display it in the TT. Nevertheless, there are some instances in which this dirty language is neutralized in the TT, probably because the translator decided not to show as many vulgar allusions as the original presents in an effort to bring about a more neutral subtitled version. As regards blasphemous language, the wide variety of curse words in Spanish contrasts with their scarcity in English. In such instances the translations usually exhibit euphemisms or omissions, so that both strategies diminish the vulgarity of the original speech. As for insulting and scatological language, there seems to be no consistency among translators: while most translations achieve an equivalent effect of the original by presenting the same kind of language in the TT, others either show euphemisms for the source expression or omissions, which explains the loss of the original flavor of the film.

As for sexual and bodily functions, subtitles exhibit close equivalents whenever possible. The existence of English equivalents for most of these expressions has led translators to keep the original flavor of the film by showing their equivalents in the TT. Nevertheless, the continuous repetition of the same dirty word in the ST has usually been avoided in the TT. Perhaps translators regarded it as unnecessary to repeat these same obscenities so many times, as over-use would sound unnatural for the target audience. Sometimes the translations have displayed euphemisms that also diminish the vulgarity of the original. By means of these two strategies translators 
have subscribed to the target norms. For the target audience is not used to as much foul language as the source audience, an over-use of such language could create problems for the target spectator's understanding. Yet the omission and neutralization of such language does deprive the target audience of an appreciation of the full identity and originality of the film.

While swearing is very common in the Spanish language, and there is a great variety of swear words and expressions, English does not have exact equivalents for all of them. Nevertheless, as Díaz Cintas \& Remael (2007: 199) suggest, "swearwords, taboo words and interjections will $[. .$.$] often have to be translated differently in$ different contexts, and their meanings can be a matter of interpretation". Whenever there is an equivalent, the TT displays it, and thus maintains the vulgar tone of the original. But some Spanish swear words do not have exact equivalents in English, and such a problem is overcome by means of introducing another obscenity in the TT. In contrast to the wide sampling of swear words that appear in Almodóvar's films, the subtitles do not exhibit such a variety of expletives due to their non-existence in English. Nevertheless, despite this scarcity in English, for the most part, these translations do preserve the lack of refinement of the ST. On other occasions, the subtitles either present omissions or softer versions of the vulgar $\underline{\text { term: }}$

[...] Not each and every swearword needs to be translated in order to convey characters' registers and/or personalities: peppering their speech with the occasional well-placed expletive will often do the trick. Moreover, using synonyms is also a way out [...]. (Díaz Cintas \&Remael 2007: 200) 
Due to these strategies, some of the characters do not appear as offensive and unrefined in the subtitled version. In addition, there are cases in which the TT uses an expression that is surprisingly even more vulgar and violent than the source one, but it is difficult to know exactly why translators chose it.

In some of Almodóvar's works, there are characters that represent the Spanish rural lifestyle. These characters are usually played by Lampreave and by the director's real mother, doña Paquita, and their language is full of culture-rooted remarks that usually have no equivalent in the TL. They embody wisdom and advice, and humor pervades almost all their speeches. In the subtitles, however, these speeches lack the same originality and humor. The equivalent effect is difficult to achieve due to the nonexistence of an equivalent register in English. The TT usually displays the content of the ST, but the idiosyncratic speech is totally lost, and thus the source humor is not transmitted in the subtitles. In certain cases the TT displays a wrong translation of the ST, as if the translator were not aware of the real meaning. In other cases translators have decided to display a cultural non-equivalent that may make no sense for the target spectator, but which preserves the cultural identity of the film. In other words, a target audience not conversant with Spanish will be deprived of the humor and particularities of the rural language so characteristic of Almodóvar's films.

Most of the characters' speech pattern is linked to their social condition and lifestyle, so that their speeches are usually full of slang and colloquial expressions whose equivalents in the TL are sometimes nonexistent: 
Colloquial language always carries the mark of a certain time and a certain generation, and $[\ldots]$ this fact must be taken into account when translating. (Bravo 2002: 201)

In such cases, the translators have usually decided to transmit the original content of the ST, leaving out these particularities. The Madrid slang dialect that originated in the 1980s - Cheli - is impossible to render in the translations. Because of its nonexistence in the TL, most translations display standardizations or neutralizations. Thus, such strategies entail the loss of the original flavor of the film in the subtitled version. On the other hand, some translators have at times been able to achieve the equivalent effect of the original register by choosing a fluid and colloquial style in the TT that also transmits the original content. By contrast, these same translators have surprisingly omitted some of the original speeches. In such cases, translators may have thought it unnecessary to repeat the same word as many times as in the ST for reasons of irrelevance. By in so doing, they have not respected the uniqueness of the film. In fact, the humor present in this type of language is not well transmitted in the subtitles, mostly because of the translators' strategy of transmitting the message of the ST by leaving aside any stylistic characteristic of the speech. Once again there are inconsistencies in the translation: some words or expressions are not always translated in the same way, while others are simply wrong translations.

EI trasvase de acentos y dialectos, para cuya traducción aún no se ha encontrado una solución satisfactoria, aunque los lingüistas hayan demostrado que los acentos y los dialectos no son elementos decorativos o toques de exotismo, sino que constituyen 
una verdadera mina de información en la vida, en general, $y$ en el cine, en particular, $[. .$.$] porque transmiten gran cantidad de$ información sobre el hablante $y$, si sabemos leer los códigos correspondientes, nos revelan inmediatamente su procedencia geográfica, extracción social, educación, preparación cultural, etc. (Bravo 2005:137)

As regards accents, subtitles are unable to reproduce them. The Andalusian accent of many characters in these films, and the humor linked to them, is not rendered in the translations. Indeed, the textual character of the subtitling process presents difficulties in its representation. Even though the geographical references to the place of origin of some characters are not essential to the storyline, they contribute to the humor of the film. Indeed, Andalusian is a humorous accent in Spain, and only the target audience's knowledge of Spanish can help in the appreciation of such a regional accent and the humor it contains. In fact, in most cases the translators deal with the dialectal features in the speech of some characters by omitting them in the subtitling process. Thus, the translations of these speeches usually only transmit the original content, ignoring any dialectal aspect of the ST.

Though it may be true that the world today is undergoing a process of globalization and that, pushed along by the existence of mass media, the various and diverse world cultures would seem to integrating into a sort of shared process and which remain unique to a given culture. Among these, humor occupies an important position [...]. (Bravo 2002: 202)

Because most translators choose to communicate the original content of the films, while disregarding other particularities, humor is not 
fully transferred in the translations, even though there are some strategies translators may follow: "[... evaluating the importance of humorous passages $[\ldots]$ will help produce adequate translations and will limit frustration about unsolvable problems, since some jokes are not as important as others" (Díaz Cintas \& Remael 2007: 215). As previously stated, humor does not usually depend on what is said, but on how it is said, and most humorous comments and allusions are hilarious precisely because of the presence of colloquialisms or particular accents. If these characteristics are not transmitted in the translations, the target spectator is deprived of this humor. The speeches of characters such as Candela in Mujeres al borde de un ataque de nervios, and of Agrado, the most witty character in Todo sobre mi madre, are not as amusing in the TT. By contrast, the Spanish spectator enjoys every one of the speeches by these characters, unlike the target spectator who is not given such an opportunity.

Cualquier texto cinematográfico puede contener referentes culturales inexistentes en la cultura meta, y la consecuencia de todo lo anterior es que, dado su carácter de textos híbridos de naturaleza verboicónica, al traducir las películas, en cierta medida, las convertimos en productos bi-culturales, pues la imagen, que es intocable para el traductor, representa a una cultura determinada y la traducción está escrita en una lengua distinta y es portadora de otra cultura, fenómeno que, a veces, coloca al traductor ante problemas insalvables o muy difíciles de solventar sin poner en grave peligro el equilibrio estilístico del film. (Bravo 2005: 137)

Cultural equivalence does not seem to be of primary importance in subtitling, as it involves evaluating all the information the target 
spectator can assimilate; a loss of information is usually expected. In the translations of Almodóvar's films, cultural references seem to be secondary information, so that the atmosphere of the film is threatened in the target version. Most cultural references are not translated by means of a suitable equivalent in the target culture. Equivalents of popular Spanish personalities such as Marujita Díaz, Concha Piquer, or historic characters such as Genoveva de Bravante, may not have a suitable counterpart in an Anglo-Saxon or Anglo-American culture because of the obvious differences between the source and the target cultures. Yet translators do try to find the most appropriate target character, even though some translations are not adequate in content, as leaving his or her name in the subtitle may be mystifying (Díaz Cintas \& Remael 2007: 205). Most cultural references have been domesticated in the subtitles, so that a natural and fluid style can be provided in the TL, while leaving aside any stylistic characteristic of the ST. The allusions made to specific geographical places in Spain are usually abbreviated for the target audience, and places such as "la Costa del Sol" are displayed as "coast" in the subtitles. The mentions of cities such as Madrid where most of his films take place -, Barcelona or Málaga, are usually not reflected in the TT, thus depriving the target audience of the geographical reference. However, it seems that:

[...]The trend to keep cultural references unchanged in the subtitles is also becoming more pronounced in languages like Italian and Spanish, raising issues regarding comprehensibility of the translation as well as prominence of the English language and cultures. The fact that the soundtrack is heard and the audience might spot the discrepancy between subtitle and dialogue is one of 
the common reasons put forward to justify this type approach. (Díaz Cintas \& Remael 2007: 205-206)

As for gastronomv, the translators' favorite alternative seems to be to find the equivalent for the Spanish food in the target culture, therefore depriving the film of any reference to the foreign context. But, there are, of course, cases when such equivalence does not exist, which forces the translators either to omit the food reference, and thus loses the content, or to display the source reference in the TT, thus enriching the target culture, and at the same time, respecting the cultural identity of the film.

The wordplay found in the dialogues of some films is sometimes hard to communicate in the TT:

El juego de palabras, como figura literaria, se basa en la singularidad semiótica que ciertos componentes léxicos adquieren en un texto determinado, en función de sus características fonéticas y gráficas, así como de sus significados. Descifrar este recurso estilístico constituye un extraordinario desafío para el traductor de textos audiovisuales, puesto que tiene que reproducir en su traducción, los distintos significados de las palabras, la disposición de los significantes y lar relevancia ideológica y cultural que el término tiene en el guión original.(Rodríguez Espinosa 2001: 111).

Wordplay having to do with Spanish culture seems to be untranslatable, forcing the translator to focus on the transmission of the content of the original, which sometimes is not sufficient for the foreign spectator's comprehension. Because of this strategy, the target audience may feel lost or confused, as well as deprived of the humor that most puns bring about. At other times the translations exhibit puns that do not carry the same humor as the original, thus 
depriving the audience of the farce once again. On the other hand, savings are not so difficult to translate, as most of them do have equivalents in other languages. However, since there are some sayings without a TL equivalent, translators usually opt to forget about the form in order to communicate only the content.

As no work of art is completely perfect, there are errors in the translations of some of his films; these have to do either with synchronization, or with the use of grammar and vocabulary. Errors in synchronization are possibly due to a lack of revision by the $\underline{\text { translator: }}$

Poor timing, with subtitles that come in too early or too late, or leave the screen without following the original soundtrack are confusing, detract from enjoying a programme, and have the potential of ruining what may otherwise be an excellent linguistic transfer. Accurate time is curcial for optimal subtitling since it reinforces the internal cohesion of the translated programme and plays the essential role of helping the viewer identify who is saving what in the programme. (Díaz Cintas \& Remael 2007: 90)

As for other mistakes, they may have to do with a possible lack of grammatical and lexical proficiency.

All the films dealt with in this research show consistency in the translation of greetings and other formulaic expressions. These elements are usually not reflected in the TT, possibly due to the lack of information they transmit. Greetings are polite forms where translation might not be necessary, since their constant appearance on the screen may be distracting to the foreign audience. Nor are the direct addresses with proper names translated, as their translations are really irrelevant for an understanding of the story. Formulaic 
expressions such as "icómo estás?" (how are you?), "gracias" (thank you), "de nada" (you're welcome) are not translated either.

In addition to the gradual refinement in language that one observes in Almodóvar's films, there is also an evident change in the translations themselves: the older the films, the greater the number of omissions in the subtitles. In Laberinto de Pasiones, one of his first films, a large number of dialogues are not translated. It could be said that the newer the films, the better the translations. The impression is that the subtitles seem to have improved as well, probably due to the growing acceptance and celebrity of Almodóvar's works in the US. The greater the consumption of and demand for a product, the better its quality. 


\section{Conclusions}

Quienes invierten en cinematografía lo hacen con la intención de rentabilizar su inversión al máximo, para lo cual es imprescindible la traducción cinematográfica que $[\ldots]$ tiene entre otras la misión de ayudar a universalizar el film, de manera que pueda llegar, en las mejores condiciones, a la mayor cantidad de mercados que sea posible y competir con las producciones de otros países. (Bravo 2005: 127-128)

Almodóvar's way of making movies broke with the traditional film making in Spain. His irruption into foreign film markets, and more precisely into the US, began in 1989 when Mujeres al borde de un ataque de nervios was nominated for the Academy Awards. Henceforth, his productions have been characterized as original and innovative works of art. Since the US film market does not import a large number of foreign productions, the expansion of Almodóvar's works has set a precedent.

The US film market today subtitles almost all productions that are not in the English language. While the dubbing method had tried unsuccessfully to make its way into the market, audience reaction forced distribution companies to establish the subtitling method as the one to be used for foreign language productions. The origin of the subtitling method can be traced back to the appearance of sound cinema at the beginning of the $20^{\text {th }}$ century, and to the subsequent arrival of foreign productions in every country. The spectators who watched films in languages they did not understand experienced dissatisfaction, and this led film studios to think of subtitling as a solution. Yet this method met with a serious drawback: the illiteracy of the majority of the population, which 
resulted in the beginning of dubbed productions. But this still did not solve the problem, as the poor quality of dubbed versions brought about a negative audience reaction. The Hollywood industry was thus forced to produce multilingual versions of the same film, shot several times in different languages with different actors. But these multilingual versions were not a success, either, and Hollywood had to go back to subtitling as the best way of dealing with cinematographic translation. This is the method still used today in the US. Thus after the abortive attempt to dub Almodóvar's films that resulted in anger and a sense of being defrauded on the part of the spectators, all Almodóvar's films are now subtitled.

Subtitling consists in the translation of the spoken ST into a written TT superimposed on the lower part of the images of the original product. In addition to the change from the SL into the TL, there is necessarily a change from oral to written language. Herein lies the difficulty for the subtitler. Interlingual subtitling, initially seen as an elite method for those familiar with the TL, is now accepted by more and more audiences because of the growing interest in the study of languages. This method is regarded as the only one that preserves the original product, since the spectator hears the SL soundtrack while reading the subtitles in the TL.

Subtitling is cheaper than dubbing, but it poses problems for the translator. Each subtitle has to transmit the source information in two lines, each containing a maximum of 35 taps, which implies the synthesization of the ST to fit a limited space. This synthesization has to be done perfectly, or the target audience will not receive the essential information of the original. Thus this ability to synthesize on the part of the translator is of primary importance. In addition to the constrained space, the time factor is another limitation that the subtitler has to cope with, for the subtitle has to remain on the screen around 6 seconds, 
during which time the spectator is supposed to read and internalize the information received. The subtitles have to synchronize with the development of the action and the real dialogue; at the same time, they have to adjust to a reading speed that is appropriate for the spectator. In addition to these technical and textual constraints, there are other constraints for the subtitler, such as the cultural gap between SL and TL, the expressiveness of the dialogue, the style of the original, the role of the audience, etc. These restrictions also include speech patterns the preservation of which becomes a serious problem, as the subtitler is supposed to keep the 'oral flavor' of the original spoken language. The translators of Almodóvar's films have obviously faced these constraints, and I have confirmed that some subtitles have been remarkably well synthesized given the space and time limits, while others have been inaccurately translated.

While the US film market favors the subtitling of foreign productions over dubbing, the European film market presents a varied panorama in the usage of both of these two methods: countries such as Belgium, Finland, Denmark, Greece, Portugal and Sweden favor subtitling; while Spain, Germany, France and Italy prefer dubbing. The choice of one method or the other depends on economic, cultural and/or ideological factors. Besides, even though subtitling is the method chosen to translate the foreign productions that arrive in the US, censorship is still latent in this film industry. This can be verified in the analysis of the films studied.

In my analysis of the English subtitles in ten Almodóvar films, I have studied some of the characteristics of the dialogues of these films: insulting and scatological expressions, expression concerning sexual and bodily functions, rural language, swear words, slang and colloquial expressions, accent, cultural references, vocabulary related to drugs, and wordplay and sayings. My overall objective has 
been to determine what the policy governing these translations has been. In other words, I have tried to find out whether the translations of the films of Almodóvar follow the principle of dynamic equivalence, and in terms of the polysystem theory, whether the target productions adhere to the criteria of adequacy or acceptability. I wanted to corroborate whether Almodóvar's translators' general policy was to subscribe to the ST norms, and thus produce an adequate or foreignizing translation, or conversely, whether they subscribed to the TT norms of producing an acceptable or domesticated translation. By providing a micro structural level of analysis, norms help us make clear the translator's behavior in the process of translation, as it should be born in mind that "the initial norm decides the basic choice of a translator, that is, whether he or she gives priority to the original language and culture or to the target language and culture" (Agost 2004: 69).

Most of the films analyzed reflect the middle and lower class life. Almodóvar belongs to a middle class family who had to migrate in search of a better life. He loyally represents his own family in his productions, introducing characters whose lives are not easy, and who have low grade jobs and trouble trying to survive until the next pay check. Some of them are addicted to drugs, some work as prostitutes. The audience cannot expect them to talk in a refined style, as most of them are not educated. Some characters are not proficient in Spanish, and their dialogues are full of bad grammar and vocabulary. This film-maker portrays an innovative and different image of a country that was for a long time ruled by a dictatorship. This may be the clue to his success outside Spain, as his cinematic language has been described as exhilarating, extremely amusing, and eclectic, to name just a few of the adjectives used. 
Spaniards, in general, have a tendency to use "dirty" language in their everyday speech, no matter which social class they belong to. It goes without saving that the language that distinguishes Almodóvar's characters is full of expressions that are considered dirty and vulgar. However, when it comes to their translation, an objective evaluation of their translation is problematic because the studies dealing with the social and communicative function of swear words are scarce. Resorting to dictionaries is not sufficient, as they usually give neutral translations that in general do not correspond to the speaker's intention, or to the specific situation in which they are produced. As for the translation of taboo terms:

First, the translator must determine whether a given term has its own semantic content or if it is simply a means of conveying emphasis. If it is functional [...], it must be translated with care. An additional problem emerges when there is an accumulation, or concentration, of a large number of these terms over a limited amount of screen time. The translator must decide whether or not it is appropriate to shower the audience with such a torrent of obscenities. (Bravo 2002: 203-204)

In the best of worlds, the production company or customer commissioning the subtitles will supply a dialogue list that also contains a glossary, explaining all such instances of marked language, and a host of other linguistic and cultural particularities [...]. It remains up to the subtitler to determine how to translate a given term or expression. (Díaz Cintas \& Remael 2007: 187)

It is not the subtitler's work to act as a censor, so "if a producer or director has chosen this particular level of expression, the subtitler should not try to raise it" (Ivarsson \& Carroll 1998: 127). 
After my research, I have come to the conclusion that there is a gradual change in the language of Almodóvar's characters, as well as a change in tone and style. While his first films are full of indelicate language, the characters in the latest ones manifest a much more neutral speech pattern, easily confirmed in the examples I give in my analysis.

La investigación ha demostrado que los principales focos de irradiación de dificultades [en la traducción cinematográfica] son los siguientes: una serie de problemas microlingüísticos especialmente: las interferencias de la LO sobre la LM; el argot; el humor; los términos tabú y los apelativos cariñosos -; los problemas culturales; los dialectos y los acentos; la subordinación a la imagen. (Bravo 2005: 136)

In my study, I have found out that the subtitles do not always exactly reflect Almodóvar's language:

If all characters speak the same linguistic variant, not that much may be lost, but if one or a few stand out because of the type of language they speak, this should somehow be reflected in the dialogue exchanges. In such cases connotative meaning contributes to denotative meaning. (Díaz Cintas \& Remael 2007: 186)

In the films analyzed, I have noted a tendency on the part of some subtitlers to eliminate unrefined language. However:

The translation of taboo words and swearwords is crucial when they contribute to characterization or when they fulfill a thematic function in a film. This happens, for instance, in many Almodóvar's 
films where women use macho language normally associated with men (Arnáiz 1998). [...] Rendering [the] idiosyncratic use of expletives and taboo words is therefore crucial both from a narrative and a thematic viewpoint. (Díaz Cintas \& Remael 2007: $\underline{197)}$

These translators have resorted to various strategies when dealing with this type of speech. On the one hand, when there are obvious equivalents in the TL, the tendency is to use them, and thus keeping the vulgarity of the ST. But this is not always the case: in some instances such language is softened by means of euphemisms, and even deletions of the source terms can also be observed in other instances. By means of such neutralization, the translations are made more acceptable for the target audience. These findings demonstrate that the translators of Almodóvar's films are aware of the film industry they are working for, and of the target norms and conventions that need to be followed in the translation process.

Nevertheless, it is interesting to find censorship of vulgar language in the translation of Almodóvar's films. By contrast, it is also interesting to find that many of the most recent US productions do exhibit vulgar speech patterns that are uttered once in a while, and are not even justified in the plot. I have confirmed that the translations of some of the, what I call, colorful expressions in Almodóvar's films usually follow the norm of acceptability, thus losing the colorfulness of the original. Sometimes the subtitles reflect an even more violent and vulgar language than that of the ST ("fuck off" as the translation for "ianda, piérdete por ahí!" or "cock" as the translation for "glande"), which is a striking departure, from the strategy used by these translators. One can only wonder why some subtitles display unrefined language in instances in which the ST 
does not even contains any such vulgarity. These translators seem to be contradicting the target norms they have largely subscribed to, thereby confusing the target audience.

As regards the presence of mature or elderly people, it is noteworthy that even though Almodóvar does not include many such characters in his films, the presence of characters such as the grandmother in ¿Qué he hecho yo para merecer esto?!, or Almodóvar's own mother in some films, is part of his social observation (García de León \& Maldonado 1989: 86). The speech of the few elderly characters in Almodóvar is so rich in rural expressions that, at first sight, its translation is thought to be impossible. In most of these cases, I have noted that the translators have not opted for an adequate translation that adheres to the ST norms; instead, they usually provide an acceptable translation that obviously involves the loss of any hint of rural speech. Because of these strategies, Almodóvar's rural characters seem very different in the subtitled version: there is no trace of their wisdom and humor in the subtitles, and in this way the TT is depriving the target audience of their real personalities.

Whenever Almodóvar thinks of a new character, he does so in terms of his or her voice and speech pattern. All of his characters, Andalusians, people from the lower class, pimps, transvestites, etc, have many personal characteristics, the most significant being the way they express themselves. In the translation of slang and colloquial words ${ }^{34}$ and expressions, I have observed that the TTs present mostly acceptable translations, subscribing to the norms of the target culture. By means of these acceptable translations, the

\footnotetext{
34، The colloquial word is above all oral and informal, and it is identified partly with daily life; it is understood as a set of activities which are performed routinely rather than exceptionally". (Agost 1995: 188)
} 
subtitles transmit the content of the ST to the target audience. It is important to remark that colloquial language is always linked to a certain time and generation (for the most part the 1980s in Almodóvar's films). The particular speech patterns that identify the various characters are of primary importance, as they relate to their geographical, temporal and social origins. Yet they are lost in the subtitles because of the focus on the acceptability of the translation. I presume that the nonexistence of equivalents to such speech patterns in the TT accounts for the neutralizations and standardizations in the subtitles. I have come to the conclusion that, as a rule, translators have for the most part ignored the stylistic characteristics in the speech of some characters, and by doing so, have deprived the target audience of relevant information about their lifestyle and social condition. Indeed, because of this stylistic omission the reception by the target audience will significantly differ from that of the source one.

Dialects and accents provide important information about the speaker both in daily life and in films. Some of Almodóvar's characters have a distinctive Andalusian accent (Candela in Mujeres al borde de un ataque de nervios and Agrado in Todo sobre mi madre, for example), which reflects their social position and place of origin. Such an accent is difficult to show in the subtitles, mainly because of the textual character of subtitling (although it could be equated to a TL accent and set out in written form). Even though this accent is not relevant to the development of the plot, the source spectator is in a position to enjoy the speeches of characters that have such humorous intonations in Spanish. The hilarious effect of their speech has to do with the way something is said, rather than with what is said. So it is evident that the target audience will not be able to appreciate the humor of the ST. Speech patterns in Almodóvar's films are such important sources of entertainment for the source 
audience, that the humor is inevitably lost in the subtitled version. Only a target spectator with enough knowledge of Spanish will be able to perceive an Andalusian accent, or a defective use of Spanish.

During my study I have found many cultural references in Almodóvar's films. When audiovisual translators find themselves before cultural icons which may not exist in the target culture. After examining the function of the cultural reference to be translated: either its purpose is to give a touch of local flavor to the film, or it plays a functional role:

In the first of the cases above, the simplest course of action would be to provide a semantic translation or an equivalent translation using referents that are familiar in the target culture [...]. In the second case, there is no other course of action than to seek new referents which are both present and equivalent in the target culture, an ambitious and risky operation. (Bravo 2002: 208)

I have also come to the conclusion that, despite the differences between the source and target cultures, most of his translators chose acceptable translations of cultural references. Instead of trying to maintain the cultural identity of the ST, translators have usually included a US nonequivalent culture-bound reference in the TT. Food references are usually translated by using their equivalents in the target culture (domestication). However, in the absence of a TL equivalent, the source element has been kept (foreignization), usually within inverted comas. This proves that some translators have hesitated between faithfulness to the ST (foreignization) and producing a text acceptable to the target audience (domestication) to translate cultural references, - even though domestication seems to be the strategy of most translators. These translators need to be careful not to introduce cultural non-equivalents that may interfere with the understanding of the TT, or domestications of 
a reference irrelevant to the storyline. For by using domestications, the translator will tend to facilitate the target viewer's comprehension, but at the same time, sacrifice the film's cultural identity.

Almodóvar is said to have a contagious sense of humor, sometimes called "black humor", which is deeply rooted in the Spanish culture. He himself has confessed that Spaniards have a distinctively humorous way of reacting even to the worst moments, and he relates it to the Spanish 'national character'. His films are full of references to Catholicism, the family, emigration, the rural exodus and drug abuse, and the way they are portrayed in his films is a perfect example of this black humor.

Now the goal of every translator when translating humor is to achieve the same response from the target audience as from the source audience:

To accomplish this, the translator must be able to recognize - and there lies the root of the problem in many cases - those fragments of the source text which are meant to be humorous, and to identify the mechanisms by which humor is transmitted in these specific cases. This done, his next step is to "reconstruct" the text in such a way that the same effect is achieved utilizing those resources which are available in the target language/culture. (Bravo 2002: 203)

But in this study I have observed that most of the humor present in these films is usually lost in the subtitles, since it largely depends not on what is said, but on the way it is said. As I said above, if most of the slang and dirty language, or accentual characteristics are not faithfully reflected in the translation, the final result will be different from the ST. In most cases, the equivalent effect fails to be achieved because of the neutralization of some words or expressions. In the process of subtitling 
it is expected that whenever there is a humorous comment, the translators' priorities are focused on achieving the same effect in the target audience. Nevertheless in these subtitled versions, Almodóvar's translators usually create acceptable translations that facilitate the target audience's comprehension, even though the humor is unavoidably lost. Fortunately, language is not the only element that produces and contains humor: in Almodóvar's films the visual image is usually hilarious. Costumes, hair style, make-up, the characters' gestures, his postmodernist atmosphere, for the most part, contribute brushstrokes of hilarity, and this is perfectly assimilated by the target audience.

\footnotetext{
A veces, la traducción audiovisual puede llegar a ser más satisfactoria en algunos casos si el traductor / la traductora se "aparta" del componente verbal original e intenta crear elementos verbales en la lengua de llegada complementarios con las imágenes originales; en cualquier caso el resultante siempre será un nuevo texto por mucho que se mantengan inamovibles los elementos visuales del texto de partida. (Zabalbeascoa 2001: 122)
}

The present study reaches the conclusion that for the most part the subtitles of the films analyzed display acceptable translations of the STs. Thus the translators have subscribed to the norms of the target culture to which these films are addressed: a US audience that significantly differs from the source audience in many aspects such as religion, life style, cultural background, etc. The substantial differences between Spanish and North American culture condition the translators, who are constantly evaluating their translations as well as the audience for which they are meant. Present in these translations is the prevailing censorship of the US film industry: a translation that is too faithful invites censorship. While Spanish is a language full of vulgar, colorful expressions that are linked 
to sex, religion, or scatological activities, and Spaniards are used to swearing a lot, the target culture and language presents a contrast in terms of usage and frequency of such vulgar and scatological expressions. So, if translators were to reproduce every unrefined term of the SL, the final product would probably result in an improbable translation that would puzzle and confuse the target audience.

In general, the translators of Almodóvar's films have subscribed strictly to the target norms by using strategies such as neutralizations, omissions, standardizations, and euphemisms. By doing so, the indelicate nature of the speech pattern of many characters has been softened in the subtitles. Such strategies threaten the cultural identity of the film, while characters are deprived of many of their characteristics thereby losing most of their virtues or defects. For example, the hilarious nature of some of the characters is lost in translations that omit dialectal features that account for much of the humor. By ignoring the colloquial speech of some characters, the translations result in neutral expressions of the STs that cannot transmit the essence of the original. As regards cultural references, some translations display foreignizations intended to preserve the original flavor of the film. By adding these non-cultural equivalents, translators are enriching the target culture with source terms that do not interfere in the reading and understanding of the target spectator (adequate translations). On the other hand, most cultural references are domesticated, as they are meant to facilitate the target audience's comprehension of the story-line and content of the films (acceptable translations).

Almodóvar finally enjoys his deserved success in Spain. Nowadays, he is a respected film director, and the Spanish press is full of positive reviews and critiques of his films. His recognition in the United States came with the Academy Awards nomination of Mujeres al borde de un ataque de nervios. Ever since then US audiences started to discover 
his work and to impatiently wait for new releases. In fact, US film critics regard him as a genius.

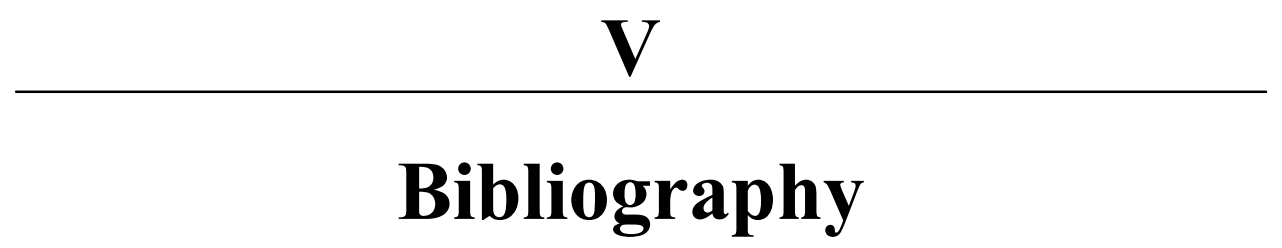

\subsection{Translation Studies}

Baker, Mona. 2004. "The Status of Equivalence in Translation Studies: An Appraisal". In: Jose María Bravo (ed.), A New Spectrum of Translation Studies. Valladolid: Univ. de Valladolid, pp. 63-71 1992. In Other Words: A Coursebook on Translation. London \& New York: Routledge

Bassnett-McGuire, Susan. 1980. Translation Studies. London \& New York: Methuen

Blatchford, C. H. 1986/1990. "Newspapers: Vehicles for Teaching ESOL with a Cultural Focus". In: J.M. Valdés (ed.), Culture Bound. Cambridge: Cambridge Univ. Press

Blanco García, Maria Pilar. 1990. "Dificultades traductológicas de las lenguas marginales en la propia comunidad lingüística”. In: Margit Raders \& Julia Sevilla (eds.) III Encuentros Complutenses en torno a la Traducción. Madrid: Editorial Complutense, pp. 41-48

Casagrande, J. B. 1954. "The Ends of Translation". International Applied Linguistics, 20, pp. 335-340

Catford, J. C. 1965. A Linguistic Theory of Translation. Oxford: Oxford Univ. Press 
Chesterman, Andrew. 1997. Memes of Translation. Amsterdam \& Philadelphia: John Benjamins Publishing 1993. "From 'is' to 'ought': Laws, Norms and Strategies in Translation Studies". Target, 5, pp. 1-20

Comitré Narváez, Isabel \& Martínez García, Adela. 1997. "Importancia de los valores culturales en la traducción de anuncios publicitarios". In: A. Vega \& Martín Gaitena (eds.) La palabra vestida: Investigaciones en torno a la traducción. Madrid: Univ. Complutense, pp.501-505

Diot, Roland. 1989. "Humor for Intellectuals: Can it be Exported and Translated?”. META, XXXIV.1, pp. 84-87

Even-Zohar, Itamar. 1978. "The Position of Translated Literature within the Literary Polysystem". In: James S. Holmes, José Lambert \& Raymond Van den Broeck (eds.), Literature and Translation: New Perspectives in Literary Studies. Leuven: ACCO, pp.117-127

Franco Aixelá, Javier. 1995. "Specific Cultural Items and their Translation”. In: Peter Jansen (ed.), Translation and the Manipulation of Discourse: Selected Papers of the CERA Research Seminars in Translation Studies 1992-1993. Leuven: Leuven Research Center, pp.109-123

Gadamer, Hans-Georg. 1977. Verdad y método. Salamanca: Sígueme

Gambier, Yves. 2003. "Introduction. Screen Transadaptation: Perception and Reception". The Translator: Special Issue on Screen Translation, 9.2, pp. 171-189

Hermans, Theo. 1995. "Disciplinary Objectives: the Shifting Grounds of Translation Studies". In: Purificación Fernández Nistal \& Jose María Bravo (coord.), Perspectivas de la traducción inglés-español. Tercer curso superior de traducción. Valladolid: Instituto de Ciencias de la Educación, pp. 9-26

1985. "Translation Studies and a New Paradigm". In Theo Hermans (coord.), The Manipulation of Literature. New York: St Martin's Press, pp. 7-15

Holland, D. \& Quinn, N. (eds.). 1987. Cultural Models in Language and Thought. New York: Cambridge Univ. Press 
Holmes, James S. 1994. Transalted! Papers on Literaty Translation and Translation Studies. Amsterdam: Rodopi 1988. The Name and Nature of Translation Studies. Amsterdam: Univ. of Amsterdam 1972. "The Name and Nature of Translation Studies". $3^{\text {rd }}$ International Congress of Applied Linguistics: Abstracts, Copenhagen

Hurtado Albir, Amparo. 2001. Traducción y traductodología: Introducción a la traductología. Madrid: Cátedra

Iglesias Fernández, Emilia. 1998. "Cultura y traducción: el traductor bicultural.” In: Carmen Valero Garcés \& Isabel de la Cruz Cabanillas (eds.), Nuevas tendencias y aplicaciones de la traducción: Encuentros en torno a la traducción. Alcalá de Henares: Univ. de Alcalá, pp. 125135

Komissarov, Vilen N. 1993. "Norms in Translation". In : Palma Zlateva (ed. and trans.), Translation as Social Action: Russian and Bulgarian Perspectives. London \& New York : Routledge, pp. 63-75

Lefevere, André. 1990. "Translation: Its Genealogy in the West”. In: Susan Bassnett \& André Lefevere (eds.), Translation, History and Culture. London \& New York: Pinter Publishers, pp. 14-28

Nida, Eugene. A. 1975. Exploring Semantic Structures. Munich: Fink

\& Taber, Charles R. 1969. The Theory and Practice of Translation.

\section{Leiden: Brill}

1964. Toward a Science of Translating: with Special Reference to Principles and Procedures involved in Bible Translating. Leiden: Brill

Payne, Robert. 1987. "On the Impossibility of Translation". In : Gregory Rabassa (ed.), The World of Translation: Papers delivered at the Conference on Literary Translation. New York: PEN Amer. Center, pp. 361-365

Ping, Ke. 1999. "Cultural Presuppositions and Misreadings". META, XLIV.1, pp. 134-143 
Rabadán, Rosa. 1991. Equivalencia y traducción: Problemática de la equivalencia translémica inglés-español. León: Univ. de León 2002. “Análisis contrastivo y traducción inglés-español: el programa ACTRES”. In: Jose María Bravo (ed.), Nuevas perspectivas de los estudios de traducción. Valladolid: Univ. de Valladolid, pp.35-56

Rabassa, Gregory. 1991. "Words Cannot Express.... The Translation of Cultures". In: Luis William \& Julio Rodríguez-Luis (eds.), Translating Latin America: Culture as Text: Translation Perspectives VI. Selected Essays from "Translating Latin America, an Interdisciplinary Conference on Culture as Text". A SUNY Conversation in the Disciplines. Binghamton: State Univ. of New York, pp. 35-44

Samaniego Fernández, Eva. 1995. "Las referencias culturales como áreas de inequivalencia interlingüística". In: Carmen Valero Garcés (ed.), Cultura sin Fronteras: Encuentros en torno a la traducción. Alcalá de Henares: Univ. de Alcalá, pp. 55-73

Sánchez, Ida Sonia. 2000. "El lenguaje y sus interfaces: Traducción y cultura". META, XLV.4, pp.683-691

Santoyo, Julio César. 1994. "Traducción de cultura, traducción de civilización". In: Amparo Hurtado Albir (ed.), Estudis sobre la traducció. Castelló de la Plana: Univ. Jaime I, pp. 141-152

Schäffner, Christina. 2001. "Skopos Theory”. In: Mona Baker (ed.), Routledge Encyclopedia of Translation Studies. London \& New York: Routledge, pp. 235-238 1999. "The Concept of Norms in Translation Studies". In: Christina Schäffner (ed.), Translation and Norms. Clevedon \& Philadelphia: Multilingual Matters Ltd, pp. 1-8

Schleiermacher, Friedrich. 1977. "On the Different Methods of Translating”. In: André Lefevere (ed. and trans.), Translating Literature: The German Tradition from Luther to Rosensweig. Assen: Van Gorcum, pp. 67-89 Snell-Hornby M. 1988. Translation Studies: An Integrated Approach. Amsterdam \& Philadelphia: Benjamins Publishing Company 
Toury, Gideon. 2004. Los Estudios Descriptivos de Traducción y más allá. Metodología de la investigación en Estudios de Traducción. Rosa Rabadán \& Raquel Merino (transl. and ed.). Madrid: Cátedra . 1995. Descriptive Translation Studies and Beyond. Amsterdam \& Philadelphia: John Benjamins

1980. In Search of a Theory of Translation. Tel Aviv: The Porter Institute for Poetics \& Semiotics

1978. "The Nature and Role of Norms in Literary Translation". In:

James S. Holmes, José Lambert \& Raymond Van den Broeck (eds.), Literature and Translation: New Perspectives in Literary Studies. Leuven: ACCO, pp. 83-100

Venuti, Lawrence. 1995. The Translator's Invisibility. London: Routledge 1993. "Translation as Cultural Politics: Regimes of Domestication in English”. Textual Practice, 7.2, pp. 206-223

Vermeer, H. J. 1982. "Translation als Informationsangebot". Lebende Sprachen, 27.3, pp.97-101105

White, J. C. 1993. "The Untranslatables: Some Solutions, or the Spirit of Translation". Essays on Translations, 1, pp. 25-29

Woodsworth, Judith 2001. "History of Translation". In: Mona Baker (ed.), Routledge Encyclopaedia of Translation Studies. London \& New York: Routledge, pp. 100-

\subsection{Audiovisual Translation}

Agost, Rosa. 2005. "Investigación descriptive en traducción audiovisual: El estudio de las normas”. In: Patrick Zabalbeascoa, Laura Santamaría, \& Frederic Chaume (eds.), La traducción audiovisual: Investigación, enseñanza y profesión. Granada: Editorial Comares, pp. 23-36 . 2004. "Translation in Bilingual Contexts: Different Norms in Dubbing Translation". In: Pilar Orero (ed.), Topics in Audiovisual Translation, 56. Amsterdam/Philadelphia: John Benjamins Publishing Company, pp. $63-82$ 
. 1995. "The Colloquial Register and Dubbing". In: Peter Jansen (ed.),

Translation and the Manipulation of Discourse: Selected Papers of the CERA Research Seminars in Translation Studies 1992-1993.

Leuven: Leuven Research Center, pp.183-200

Ávila, Alejandro. 1997. El doblaje. Madrid: Cátedra

Ballester Casado, Ana. 2001a. Traducción y Nacionalismo: La recepción del cine americano en España a través del doblaje (1928-1948). Granada: Editorial Comares

. 2001b. "El doblaje en contexto: el caso de Sangre y arena en la España de posguerra". In: Miguel Duro (coord.), La traducción para el doblaje y la subtitulación. Madrid: Cátedra, pp. 209-228

Bravo, Jose María. 2005. "La investigación en traducción cinematográfica en España: el doblaje (inglés-español)". In Raquel Merino Álvarez, José Miguel Santamaría \& Eterio Pajares (eds.), Trasvases culturales: Literatura, cine y traducción. Vitoria: Universidad del País Vasco, pp. $123-144$

. 2004. "Conventional Subtitling, Screen Texts and Film Titles". In: Jose María Bravo (ed.), A New Spectrum of Translation Studies. Valladolid: Univ. de Valladolid, pp. 209-230 . 2002. "Translating the Film Dialect of Hollywood for Dubbing". In: Jose María Bravo (ed.), Nuevas perspectivas de los estudios de traducción. Valladolid: Univ. de Valladolid, pp.187-214

Bernal Merino, Miguel Ángel. 2002. La traducción audiovisual. Alicante: Univ. de Alicante

Castro Prieto, Paloma \& Pereira Rodríguez, Ana María. 1994. "Publicidad y traducción". In: Margit Raders \& Rafael Martín-Gaitero (eds.), IV Encuentros Complutenses en torno a la Traducción. Madrid: Editorial Complutense, pp. 388-381

Castro Roig, Xosé. 2001. "El traductor de películas”. In: Miguel Duro (coord.), La traducción para el doblaje y la subtitulación. Madrid: Cátedra, pp. 267-298

Chaume Varela, Frederic. 2004. Cine y Traducción. Madrid: Cátedra 
. 2002a. "Nuevas líneas de investigación en la traducción audiovisual".

In J.M. Bravo (ed.), Nuevas perspectivas de los Estudios de Traducción. Valladolid: Universidad de Valladolid, pp. 215-224

2002b. "Models of Research in Audiovisual Translation". Babel, 48.1, pp. 1-13

Danan, Martine. 1994. "Subtitling: Multiculturalism or Commodification of Culture?”. In: Steven Tötösy de Zepetnek, Milan V. Dimic \& Irene Sywenky (eds.), Comparative Literature Now: Theories and Practice. La Littérature comparée à l'heure actuelle. Théories et Réalisations. Paris: Champion, pp. 763-773

Delabastita, Dirk. 1996. "Introduction”. The Translator, 2.2, pp. 127-139

. 1989. "Translation and Mass-Communication: Film and T.V. Translation as Evidence of Cultural Dynamics”. Babel, 35.4, pp. 193218

De Linde, Zoe. 1995. "Read my Lips: Subtitling Principles, Practices, and Problems". Perspectives: Studies in Translatology 1. Copenhagen: Museum Tusculanum Press, Univ. of Copenhagen, pp. 9-20

De Linde, Zoe \& Kay, Neil. 1999. The Semiotics of Subtitling. London: St. Jerome

Del Río Fernández, Rocío. 2001. "Problemática del subtitulado y el doblaje en la traducción cinematográfica”. In: Isabel Pascua Febles (coord.), La traducción. Estrategias profesionales. Las Palmas de Gran Canaria: Univ. de las Palmas de Gran Canaria, pp. 219-228

Díaz Cintas, Jorge. 2005. «Teoría y traducción audiovisual». In: Patrick Zabalbeascoa, Laura Santamaría, \& Frederic Chaume (eds.), La traducción audiovisual: Investigación, enseñanza y profesión. Granada: Editorial Comares, pp. 9-21 . 2004. «In Search of a Theoretical Framework for the Study of Audiovisual Transaltion». In: Pilar Orero (ed.), Topics in Audiovisual Transaltion, vol. 56. Amsterdam/Philadelphia: John Benjamins Publishing Company, pp. 21-34 
2001. "Los Estudios sobre Traducción y la traducción fílmica”. In: Miguel Duro (coord.), La traducción para el doblaje y la subtitulación. Madrid: Cátedra, pp. 91-102

. 1998. "Propuesta de un marco de estudio para el análisis de subtítulos cinematográficos". Babel, 44.3, pp. 254-267

Díaz Cintas, Jorge \& Remael, Aline. 2007. Audiovisual Translation: Subtitling. Manchester: St Jerome Publishing

D’Ydewalle, Géry \& Van de Poel, Marijke. 1999. "Incidental ForeignLanguage Acquisition by Children Watching Subtitled Television Programs". Journal of Psycholinguistic Research, 28.3, pp. 227-244

Friedman, Sonya. 1974. "Subtitling: The Art of the Film Translator". In: T. Ellen Crandell (ed.), Translators and Translating: Selected Essays from the American Translators Association Summer Workshops. New York: State Univ. of New York, pp. 43-46

Gambier, Yves. 2003. "Introduction. Screen Transadaptation: Perception and Reception". The Translator: Special Issue on Screen Translation, 9.2, pp. 171-189

\& Suomela-Salmi, Eija. 1994. "Subtitling: a Type of Transfer". In: Federico Eguiluz, Raquel Merino, Vicky Olsen, Eterio Pajares \& Jose Miguel Santamaría (eds.), Transvases culturales: Literatura, cine y traducción. Vitoria: Univ. del País Vasco, pp. 243-252

Gilabert, Ana, Ledesma, Iolanda \& Trifol, Alberto. 2001. "La sincronización y adaptación de guiones cinematográficos". In: Miguel Duro (coord.), La traducción para el doblaje y la subtitulación. Madrid: Cátedra, pp. 325-330

Gordo Peleato, Rosario. 1996. "An Example of Constrained Text: The Subtitles". In: Beatriz Penas Ibáñez (ed.), The Intertextual Dimension of Discourse. Zaragoza: Univ. de Zaragoza, pp. 51-56

Gottlieb, Henrik. 2004. "Language-political Implications of Subtitling". In Pilar Orero (ed.), Topics in Audiovisual Translation, vol. 56. Amsterdam/Philadelphia: John Benjamins Publishing Company, pp. 83-100 
1994. "Subtitling: Diagonal Translation". Perspectives: Studies in

Translatologv, 2.1, pp. 101-121

. 1992. "Subtitling - A New University Discipline". In: Cay Dollerup

\& Anne Loddegaard (eds.), Teaching Translation and Interpreting:

Training, Talent and Experience. Denmark: John Benjamins, pp. 161-170

Grillo, Virgil \& Kawin, Bruce. 1981. "Reading at the Movies: Subtitles, Silence, and the Structure of the Brain". Post Script: Essays in Film and the Humanities. Commerce, 1.1, pp. 25-32

Guardini, Paola. 1998. "Decision-Making in Subtitling”. Perspectives: Studies in Translatology, 6.1, pp. 91-112

Gubern, Román. 2001. "Infidelidades”. In Miguel Duro (coord.), La traducción para el doblaje y la subtitulación. Madrid: Cátedra, pp. 83-89

Gutierrez Lanza, Camino. 2005. "EDT basados en corpus textuales informatizados: Perfeccionamiento metodológico en TRACEci”. In: Patrick Zabalbeascoa, Laura Santamaría, \& Frederic Chaume (eds.), La traducción audiovisual: Investigación, enseñanza y profesión. Granada: Editorial Comares, pp. 87-98 . 2000, Traducción y censura de textos cinematográficos en la España de Franco: Doblaje y subtitulado inglés-español (1951-1975). León: Univ. de León 1997. "Spanish Film Translation: Ideology, Censorship and the Supremacy of the National Language”. In: Marian B. Labrum (ed.), The Changing Scene in World Languages: Issues and Challenges. Amsterdam \& Philadelphia: John Benjamins, pp. 35-45

Howard, Laura. 1994. "Film Subtitling: a Challenge for the Translator". In: Rafael Martín-Gaitero (ed.), V Encuentros Complutenses en torno a la Traducción. Madrid: Editorial Complutense, pp. 583-587

Hurtado Albir, Amparo. 2001. Traducción y traductodología: Introducción a la traductología. Madrid: Cátedra

Ivarsson, Jan. 1992. Subtitling for the Media. Stockholm: Transedit Ivarsson Jan \& Mary Carroll. 1998. Subtitling. Sweden: Transedit 
Izard, Natalia. 2001. "Doblaje y subtitulación: una aproximación histórica". In: Miguel Duro (coord.), La traducción para el doblaje y la subtitulación. Madrid: Cátedra, pp. 189-208

Karamitroglou, Fotios. 2000. Towards a Methodology for the Investigation of Norms in Audiovisual Translation: The Choice between Subtitling and Revoicing in Greece. Approaches to Translation Studies. Amsterdam: Rodopi 1998. "A Proposed Set of Subtitling Standards in Europe". Translation Journal 2.2 (http://accurapid.com/journal/04stndrd.htm)

Kilborn, Richard. 1989. "They Don't Speak Proper English: A New Look at the Dubbing and Subtitling Debate". Journal of Multilingual and Multicultural Development, 10.5, pp. 421-434

Kovacic, Irena. 1998. "Six Subtitlers - Six Subtitling Texts". In. Lynne Bowker (ed.) Unity in Diversity: Current Trends in Translation Studies. Manchester: St. Jerome, pp.75-82 . 1995. "Reinforcing or Changing Norms in Subtitling". Teaching Translation and Interpreting 3: New Horizons, 9.1, pp. 105-109

Leboreiro Enríquez, Fernanda \& Poza Yagüe, Jesús. 2001. "Subtitular: toda una ciencia... y todo un arte”. In: Miguel Duro (coord.), La traducción para el doblaje y la subtitulación. Madrid: Cátedra, pp. 315-323

Mayoral Asensio, Roberto. 2001. "Campos de estudio y trabajo en traducción audiovisual”. In: Miguel Duro (coord.), La traducción para el doblaje y la subtitulación. Madrid: Cátedra, pp. 19-45

1994. "La explicitación de la información en la traducción intercultural". In: Amparo Hurtado (ed.), Estudis sobre la traducció. Castelló de la Plana: Univ. Jaime I, pp.73-96

. 1993. "La traducción cinematográfica: El subtitulado". Sendebar, 4, pp. $45-68$

et al. 1988. "Concept of Constrained Translation: Non-Linguistic Perspectives of Translation". Meta 33.3: 356-367 
Merino, Raquel. 2005. "Traducción, adaptación y censura de productos dramáticos". In: Frederic Chaume \& Rosa Agost (eds.), La traducción en los medios audiovisuales. Castellón: Univ. Jaume I, pp. 231-238

Nedergaard-Larsen, Birgit. 1993. "Culture-Bound Problems in Subtitling". Perspectives: Studies in Translatology, 2.2, pp. 207-241

Nornes, Abé Mark. 1999. "For an Abusive Subtitling". Film Quarterly, 52.3, pp. 17-34

O'Connell, Eithne. 1998. "Choices and Constraints in Screen Translation". In: Bowker \& Lynne (eds.), Unity in Diversity? Current Trends in Translation Studies. Manchester: St. Jerome, pp. 65-71 1994. "Media Translation and Lesser-used Languages: Implications of Subtitles for Irish Language Broadcasting”. In F.Eguíluz et al., Trasvases Culturales: Literatura, Cine, Traducción. Vitoria: Universidad del País Vasco

Piastra, Liliana. 1989. "La traducción cinematográfica". Fidus Interpres : Actas de las Primeras Jornadas Nacionales de Historia de la Traducción. Volumen II. León: Univ. de León, pp. 344-352

Rabadán, Rosa. 1991. Equivalencia y traducción: Problemática de la equivalencia translémica inglés-español. León: Univ. de León

Reid, H. 1991. "Linguistic Problems Associated with Subtitling". In: G.M. Luyken et al. (eds.), Overcoming Language Barriers in Television. Dubbing and Subtitling for the European Audience. Manchester: The European Institute for the Media, pp. 156-158 1977. "Sub-Titling, the Intelligent Solution". In: P.A. Horguelin (ed.), La traduction, une profession - Translating, a profession. Ottawa: pp. $420-428$

Titford, C. 1982. "Subtitling-Constrained Translation". Lebende Sprachen, 27.3, pp. 113-116

Tomaszkiewicz, Teresa. 2001. "Transfert des Références Culturelles Dans les Sous-titres Filmiques». In: Yves Gambier \& Henrik Gottlieb (eds.), (Multi) Media Translation: Concepts, Practices, and Research. Amsterdam: John Benjamins, pp. 237-247 
Törnquist, Egil. 1995. "Fixed Pictures, Changing Words: Subtitling and Dubbing the Film Babettes Gaestebud". Tijdschrift voor Skandinavistiek, 16.1, pp .47-64

Torregrosa, Carmen. 1996. "Subtítulos: traducir los márgenes de la imagen". Sendebar, 7, pp. 73-88

Whitman, C. 1992. Through the Dubbing Glass. Frankfurt: Peter Lang

Wuilmart, Françoise. 1995. "La cuestión de la elección del idioma en cine y televisión". In: Rafael Martín-Gaitero (ed.), $V$ Encuentros Complutenses en torno a la Traducción. Madrid: Editorial Complutense, pp. 499-505

Zabalbeascoa, Patrick. 2001a. "El texto audiovisual: Factores semióticos y traducción”. In John D. Sanderson (ed.), ;Doble o Nada! Actas de las I y II Jornadas de doblaje y subtitulación de la Universidad de Alicante. Alicante: Universidad de Alicante, pp. 113-126 2001b. "La traducción del humor en textos audiovisuales". In: Miguel Duro (coord.), La traducción para el doblaje y la subtitulación. Madrid: Cátedra, pp. 251-263 . 1996. "Translating Jokes for Dubbed Television Situation Comedies". The Translator, 2.2, pp. 235-267

Zaro Vera, Juan Jesús. 2001. "Conceptos traductológicos para el análisis del doblaje y la subtitulación”. In: Miguel Duro (coord.), La traducción para el doblaje y la subtitulación. Madrid: Cátedra, pp. 47-63

\subsection{Translation of Humor}

Adrjan, Pawel \& Muñoz-Basols, Javier. 2003. "The Sound of Humor: Linguistic and Semantic Constraints in the Translation of Phonological Jokes". SKY Journal of Linguistics, 16, pp. 239-246

Attardo, Salvatore. 2002. "Translation and Humour: An Approach Based on the General Theory of Verbal Humour (GTVH)". The Translator: Translating Humour, 8.2, pp. 173-193 
\& Raskin, Victor. 1991. "Script Theory Revis(it)ed: Joke Similarity and Joke Representation Model”. Humor, 4.3/4, pp. 293-34

. 1989. "Morfología Della barzelletta". Studi italiani di lingüistica teorica ed applicatta 3. In press

Bergson, Henri. 1945. Le Rire. Essai sur la Signification du Comique. Genève: Éditions Albert Skira

Bernal Merino, Miguel Ángel. 2002. La traducción audiovisual. Alicante: Univ. de Alicante

Chiaro, Delia. 1992. The Language of Jokes: Analysing Verbal Play. London \& New York: Routledge

Diot, Roland. 1989. "Humor for Intellectuals: Can it be Exported and

Translated?". META, XXXIV.1, pp. 84-87

Duchaj, Karen Ann. 1999. Individual Differences in Humor Appreciation: The Role of the Semantic Scripts. Dissertation Abstracts International, Section A: The Humanities and the Social Sciences, 60(6). Northwestern University

Herzog, Thomas R. \& Karafa, Joseph A. 1998. "Preferences For Sick Versus Non-sick Humor". Humor, 11.3, pp. 291-312.

\& Bush, Beverly A. 1994. "The Prediction of Preference for Sick Humor". Humor, 7.4, pp. 323-340

Johnson, A. Michael. 1992. "Language Ability and Sex Affect Humor Appreciation". Perceptual and Motor Skills, 75, pp. 571-581

Leibold, Anne. 1989. “The Translation of Humor; Who Says it Can't be Done?”. META, XXXIV. 1, pp. 109-111

Leventhal, Howard \& Cupchik, Geral C. 1975. "The Informational and Facilitative Effects of an Audience Upon Expression and the Evaluation of Humorous Stimuli”. Journal of Experimental Social Psychology, 11, pp. 363-380

Mundorf, Norbert, Bhatia, Azra, Zillmann, Dolf, Lester, Paul \& Robertson, Susan. 1988. "Gender Differences in Humor Appreciation". Humor, 1.3, pp. $231-243$ 
Nash, Walter. 1985. The Language of Humour: Style and Technique in Comic Discourse. London \& New York: Longman

Norrick, Neal R. 1989. "Intertextuality in Humor”. Humor, 2.2, pp. 117-139

Popovic, Anton. 1976. Dictionary for the Analysis of Literary Translation. Edmonton: Univ. of Alberta, Department of Comparative Literature

Raphaelson-West, Debra S. 1989. "On the Feasibility and Strategies of Translating Humor". META, XXXIV.1, pp. 128-141

Raskin, Victor. 1985. Semantic Mechanisms of Humor. Boston: Kluwer Academic Publishers Group

Santoyo, Julio César. 1994. "Traducción de cultura, traducción de civilización". In: Amparo Hurtado Albir (ed.), Estudis sobre la traducció. Castelló de la Plana: Univ. Jaime I, pp. 141-152

Vandaele, Jeroen. 2002. "(Re)Constructing Humour: Meaning and Means". The Translator, 8.2, pp- 149-172 1997. "Each Time We Laugh: Translated Humour in Screen Comedy". In: Jeroen Vandaele (ed.), Translation and the (Re)Location of Meaning: Selected Papers of the CETRA Research Seminars in Translation Studies 1994-1996. Leuven: Katholieke Univ. Leuven, pp. $237-272$

Veatch, Thomas C. 1998. "A Theory of Humor". Humor, 11.2, pp. 161-215

Zabalbeascoa Terrán, Patrick. 2001. "La traducción del humor en textos audiovisuales". In: Miguel Duro (coord.), La traducción para el doblaje y la subtitulación. Madrid: Cátedra, pp. 251-266

Zillmann, Dolf. 1983. "Disparagement humor". In: P.E. McGhee \& J.H. Goldstein (eds.), Handbook of Humor Research. Vol.1: Basic Issues. New York: Springer, pp. 85-107

\subsection{Reception Studies}

Abellán, Manuel L. 1987. Censura y literaturas peninsulares. Diálogos Hispánicos de Amsterdam, 5. Amsterdam: Rodopi 
Billiani, Francesca (ed.). 2007. Modes of Censorship and Translation. Manchester: St. Jerome Publishing

Black, Gregory D. 2001. "Changing Perceptions of the Movies: American Catholics Debate Film Censorship". In: Melvyn Stokes \& Richard Maltby (eds.), Hollywood Spectatorship: Changing Perceptions of Cinema Audiences. London: British Film Institute, pp. 79-90 1994. Hollywood Censored: Morality Codes, Catholics, and the Movies. Cambridge: Cambridge University Press

Holub, Robert C. 1989. "American Confrontations with Reception Theory". Monatshefte, 81.2, pp. 213-225

Hurtley, Jacqueline A. 2007. "Tailoring the Tale: Inquisitorial Discourse, and Resistance, in the Early Franco Period (1940-1950)". In: Francesca Billiani (ed.), Modes of Censorship and Translation. Manchester: St. Jerome Publishing

Lorimer, Rowland. 1994. Mass Communications: A Comparative Introduction. Manchester: Manchester Univ. Press

Merino Álvarez, Raquel \& Rabadán, Rosa. 2002. "Censored Translations in Franco's Spain: The TRACE Project - Theatre and Fiction (EnglishSpanish)”. TTR, 15.2 (electronic publication) http://www.erudit.org/revue/ttr/2002/v15/n2/007481

O'Leary, Catherine. 2005. The Theatre of Antonio Buero Vallejo. Ideology, Politics and Censorship. Woodbridge, Suffolk \& Rochester, NY: Tamesis

Prado, Gloria. 1991. "Reflexiones sobre hermenéutica literaria y teoría de la recepción desde una perspectiva de mujer". Casa de las Américas, 31.183 , pp. 26-30

Staiger, Janet. 1999. "Modes of Reception”. In : André Gaudreault, Germain Lacasse \& Isabelle Raynauld (dir.), Le Cinéma en Histoire. Institution cinématographique, réception filmique et reconstitution historique. Québec, Canada: Editions Nota Bene, pp. 305-323 1992. Interpreting films. Studies in the Historical Reception of American Cinema. Princeton: Princeton Univ. Press 
Toral, Carolina. 1946. "Ensayo de selección para niñas de once a dieciséis años”. Bibliografía Hispánica, 7 (July): 455-463

Vandaele, Jeroen. 2007. "Take Three”. In: Francesca Billiani (ed.), Modes of Censorship and Translation. Manchester: St. Jerome Publishing

\subsection{Pedro Almodóvar}

Acevedo-Muñoz, Ernesto R. 2004. “The Body and Spain: Pedro Almodóvar's All About My Mother". Quarterly Review of Film and Video 21: 2538

Almodóvar, Pedro. 1999. Todo sobre mi madre. Madrid: El Deseo Ediciones

Allinson, Mark. 2001. A Spanish Labyrinth: The Films of Pedro Almodóvar. London \& New York: I.B. Tauris

Amago, Samuel. 2007. "Todo sobre Barcelona: Refiguring Spanish Identities in Recent European Cinema”. Hispanic Research Journal 8.1 (2007): $11-25$

Ansen, David. 1988a. "Pure Pedro: Almodóvar's Finest Hour". Newsweek, 22 November, pp. 91 . 1988b. "The Man of La Mancha: A Taboo-Smashing Director Revels in the New Spain". Newsweek, 5 December, pp. 88

Bayon, Miguel. 1989. “A Winner from Spain.” World Press Review 36.4 (1989): 60.

Blake, Richard A. 2000. "All About Mamacita (All About My Mother) (movie review)". America, 26 February, pp. 21

Cadalso, Isabel. 1988. "Pedro Almodóvar: A Spanish Perspective". Film Comment, 24.6, pp. 36-37

Cardullo, Bert. 1991. "Lovers and Other Strangers". The Hudson Review, pp. $645-653$

Colmeiro, José F. 1997. "Del rosa al negro: subtextos culturales en La flor de mi secreto". Arizona Journal of Hispanic Cultural Studies, 1, pp. 115128 
Corbalán, Ana M. 2006. El cuerpo del delito: Transgresiones en la narrative y cine españoles de fines del milenio. University of North Carolina at Chapel Hill. Doctoral thesis.

Corliss, Richard. 1992. "High Heels (movie reviews)". Time, 10 February, pp. 76 1989. "Pedro on the Verge of a Nervy Breakthrough". Time, 30 January, pp. 68-69

Deveny, Thomas. 2000. "Carne trémula: An Almodovaresque Screen Adaptation”. West Virginia Univ. Philological Papers, pp. 129-136

D'Lugo, Marvin. 2002. "Recent Spanish Cinema in National and Global Contexts". Post Script, 21.2, pp. 3-12 . 1991. "Almodóvar's City of Desire". Quarterly Review of Film and Video, pp. 47-65

Elgrably, Jordan. 1992. "Anti-macho Man”. Los Angeles Times, 19 January, pp. 18+

Fernández Dobao, Ana María. 2006. « Lingüistic and cultural aspects of the translation of swearing: The Spanish version of Pulp Fiction ». Babel, 52.3, pp. 222-242

García de León, Maria Antonia \& Maldonado, Teresa. 1989. Pedro Almodóvar, la otra España cañi (sociología y crítica cinematográficas). Ciudad Real: Diputación de Ciudad Real

Goss, Brian Michael. 2008. Book review of "D'Lugo, M. (2006). Pedro Almodóvar. Urbana: Unviersity of Illinois Press." Journal of Communication Inquiry, 32.1, pp. 83-94

Hart, Patricia. 1994. "Can a Good Feminist Sit Through Kika? Rape, Recovery, and Submission Fantasies in the Films of Almodóvar". Anuario de cine y literatura en español , 3, pp. 73-88

Holland, Jonathan. 1998. "Pedro Reigns in Spain: Almodóvar Still Considered an Icon". Variety, 20 April, pp. 39-40

Jaramillo, Juan F. 2006. "El mundo según Almodóvar". La Vida, 1 September, pp. 6-8 
Kauffman, Stanley.1994. "Kika (movie reviews)". The New Republic, 6 June, pp. 26-27

. 1992a. "Pepi, Luci, Bom (movie reviews)". The New Republic, 29 June, pp. 28-29

. 1992b. "High Heels (movie reviews)". The New Republic, 3 February, pp. $28-29$

. 1990. "Tie Me Up! Tie Me Down! (movie reviews)". The New Republic, 14 May, pp. 30-31

. 1985. "What Have I Done to Deserve This? (movie reviews)". The New Republic, 20 May, pp. 24

Klawans, Stuart. 1990. "Tie Me Up, Tie Me Down (movie reviews)". The Nation, 5 December, pp. 754-755

Levy, Shawn. 1994. “Almodóvar's Kika: You Can’t Keep a Good Woman Down". Film Comment, 30.3, pp. 59-63

Maddison, Stephen. 2000. “All About Women: Pedro Almodóvar and the Heterosocial Dynamic". Textual Practice, 14.2, pp. 265-284

Martín, Annabel. 1998. “Almodóvar se tiñe de rosa: Reinscripciones melodramáticas del conocimiento y del sentir". In: George CabelloCastellet, Jaume Martí-Olivella \& Guy H. Wood, Cine-Lit III: Essays on Hispanic Film and Fiction. Corvallis: Oregon State Univ., pp. 1422

Menard, Valerie. 1998. "El Conquistador del Cine: Provocative Filmmaker Pedro Almodóvar Explores the Human Experience". Hispanic, 11.5, pp. 32-33

Morgan, Rikki. 1992. "Dressed to Kill”. Sight and Sound, I.12, pp. 28-29

O'Toole, Lawrence. 1990. "Almodóvar in Bondage". Sight and Sound, 59.4, pp. 270-273

Pally, Marcia. 1988. "The Politics of Passion: Pedro Almodóvar and the Camp Esthetic". Film Comment, 24.6, pp. 32+, 38-39

Pitt, David E. 1988. "Films Reflect a Brash New Spain". The New York Times, 1, pp. 28

Reynaud, Berenice. 1988. "Pedro Almodóvar". American Film, 13.5, pp. 72. 
Riding, Alan. 1990. "Almodóvar Takes the Pulse of Spain in Transition”. New York Times, 139, pp. 15+

Rodríguez, Jesús. 1995. “Almodóvar y la tradición melodramática de Hollywood" Anuario de Cine y Literatura en español: An International Journal on Film and Literature, 3, pp. 119-128.

Romney, Jonathan. 1999. "Performance Art (review)". New Statesman (1996,) 30 August, pp. 31.

1994. “Kika (movie reviews)". New Statesman \& Society, 1 July, pp. 33-34

Russo, Vito. 1988. "Man of La Mania”. Film Comment, 24.6, pp. 13-17

Saz, Sara. 1992. "Recepción en España de Tacones lejanos y problemas para su clasificación: ¿Culebrón, melodrama noble o musical dramático cutre?". Romance Languages Annual, 4, pp. 575-579

Stuart, Jan. 1999. "All About My Mother (review)". The Advocate, 7 December, pp. 87

Valby, Karen. 2002. "Talk to Her". Entertainment Weekly, pp. 34

Van Meter, Jonathan. 1999. "Man of Many Women”. The New York Times Magazine, pp. 67-69

Yarza, Alejandro. 1999a. "Estudios cinematográficos. La herida al aire: travestismo y ansiedad cultural en el cine de Pedro Almodóvar". In: José M. Del Pino \& Francisco La Rubia Prado (eds.), El Hispanismo en los Estados Unidos: Discursos Críticos/Prácticas Textuales. Madrid: Visor, pp. 191-209 1999b. Un canibal en Madrid: La sensibilidad camp y el reciclaje de la historia en el cine de Pedro Almodóvar. Madrid: Ediciones libertarias 1994. El reciclaje de la historia: Camp, monstruos y travestís en el cine de Pedro Almodóvar. Dissertation Abstracts Internacional, 55.3, 588A-89A. Univ. of California, Irving

Young, Tracy. 1990. “Almodóvar!! Who Inspires Spain's X-Rated Director? Doris Day, for One”. Vogue, June, pp. 124-125 


\subsection{Films by Pedro Almodóvar}

- Pepi, Luci, Bom y otras chicas del montón [Pepi, Luci, Bom and Other Girls on the Heap]. Dir. Pedro Almodóvar. Perf. Carmen Maura, Olvido Gara (Alaska), Eva Siva. Figaro Films, 1980

15. Laberinto de pasiones [Labyrinth of Passions]. Dir. Pedro Almodóvar. Perf. Cecilia Roth, Imanol Arias, Marta Fernández Muro. Alphaville, 1982

16. Entre tinieblas [Dark Habits]. Dir. Pedro Almodóvar. Perf. Cristina Pascual, Julieta Serrano, Marisa Paredes. Tesauro, 1983

17. ¿Qué he hecho yo para merecer esto! [What Have I Done to Deserve This?]. Dir. Pedro Almodóvar. Perf. Carmen Maura, Chus Lampreave, Ángel de Andrés López. Tesauro, 1984

18. Matador [Matador]. Dir. Pedro Almodóvar. Perf. Eusebio Poncela, Assumpta Serna, Antonio Banderas. Iberoamericana (and TVE), 1986

19. La ley del deseo [Law of Desire]. Dir. Pedro Almodóvar. Perf. Eusebio Poncela, Carmen Maura, Antonio Banderas. El Deseo SA, 1987

20. Mujeres al borde de un ataque de nervios [Women on the Verge of a Nervous Breakdown]. Dir. Pedro Almodóvar. Perf. Carmen Maura, Rossy de Palma, Antonio Banderas. El Deseo SA, 1988

21. ¡Atame! [Tie me up! Tie me down!]. Dir. Pedro Almodóvar. Perf. Antonio Banderas, Victoria Abril. El Deseo SA, 1990

22. Tacones lejanos [High Heels]. Dir. Pedro Almodóvar. Perf. Marisa Paredes, Victoria Abril, Miguel Bosé. El Deseo SA, 1991

23. Kika $[$ Kika]. Dir. Pedro Almodóvar. Perf. Verónica Forqué, Peter Coyote, Victoria Abril. El Deseo SA, 1993 
24. La flor de mi secreto [The flower of my secret]. Dir. Pedro Almodóvar. Perf. Marisa Paredes, Juan Echanove, Carmen Elías. E1 Deseo S.A., 1995

25. Carne trémula [Live Flesh]. Dir. Pedro Almodóvar. Perf.Javier Bardém, Francesca Nery, José Sancho, Ángela Molina, Liberto Rabal. El Deseo, 1997

26. Todo sobre mi madre [All About My Mother]. Dir. Pedro Almodóvar. Perf. Cecilia Roth, Ernesto Alterio, Marisa Paredes, Candela Peña. El Deseo SA, 1999

27. Hable con ella [Talk To Her]. Dir. Pedro Almodóvar. Perf. Javier Cámara, Dario Grandinetti, Leonor Watling, Rosario Flores. El Deseo SA, 2001

28. La mala educación [The Bad Education]. Dir. Pedro Almodóvar. Perf. Javier Cámara, Gael García Bernal. El Deseo SA, 2004

29. Volver. Dir. Pedro Almodóvar. Perf. Penélope Cruz, Carmen Maura, Lola Dueñas. E1 Deseo SA, 2006

\subsection{Dictionaries and Manuals}

Collins Cobuild. English Language Dictionary. John Sinclair (ed.). Wrotham, England: HarperCollins Publishers, 1994

Diccionario Akal del Español Coloquial. Alicia Ramos \& Ana Serradilla. Madrid: Akal Ediciones, 2000

Diccionario Collins Español-Inglés, Inglés-Español. Ed. Lorna Sinclair Knight. $6^{\text {th }}$ ed. Barcelona: Grijalbo Mondadori S.A, 2000

Dictionary of British Slang and Colloquial Expressions. Ewart James. Chicago: NTC Publishing Group, 1997

Oxford Thesaurus of English. Ed. Maurice Waite. Oxford: Oxfor Univ. Press, 2004

MLA International Bibliography. New York : MLA, 1999 
Hughes, Geoffrey. 1998. Swearing: A Social History of Foul Language, Oaths and Profanity in English. London: Penguin

\subsection{Web Sites}

http://www.canoe.ca/JamMoviesArtistA/almodovar.html

http://www.prairienet.org/ejahiel/highheel.htm

http://variagate.com/talk2her.htm

http://events.calendarlive.com/top/1,1419,L-LATimes-Movies-X

http://www.clubcultura.com/clubcine/clubcineastas/almodovar/hablecone

$\underline{\text { lla }}$

http://www.bbc.co.uk/dna/h2g2/A220537 